\title{
MICROPOLITICS and PROPERTY
}

\author{
A Thesis \\ Presented to \\ The Faculty of Graduate Studies \\ of \\ The University of Guelph \\ by \\ KAREN L. F. HOULE \\ in partial fulfilment of requirements \\ for the degree of \\ Doctor of Philosophy
}

August, 2001

C)Karen L. F. Houle, 2001 
National Library

of Canada

Acquisitions and Bibliographic Services

395 Welingon street Otinia ON K1A ONA Canada
Bibliothèque nationale du Canada

Acquisitions et senvices bibliographiques

395, nu Wellington

Otrowa ON K1A ONe4

Canada
The author has granted a nonexclusive licence allowing the National Library of Canada to reproduce, loan, distribute or sell copies of this thesis in microform, paper or electronic formats.

The author retains ownership of the copyright in this thesis. Neither the thesis nor substantial extracts from it may be printed or otherwise reproduced without the author's permission.
L'auteur a accordé une licence non exclusive permettant à la Bibliothèque nationale du Canada de reproduire, prêter, distribuer ou vendre des copies de cette thèse sous la forme de microfiche/film, de reproduction sur papier ou sur format électronique.

L'auteur conserve la propriété du droit d'auteur qui protège cette thèse. Ni la thèse ni des extraits substantiels de celle-ci ne doivent être imprimés ou autrement reproduits sans son autorisation. 


\section{ABSTRACT}

\section{MICROPOLITICS AND PROPERTY}

Karen L.F. Houle

University of Guelph, 2001
Advisor:

Professor Jay Lampert

This thesis is an investigation of the feasibility of a micropolitical analysis as an evaluative scheme for the analysis of property. The limitations of historical and normative frameworks are discussed. The ontological features of power as understood by Filmer and Locke are compared, and these, to a Foucauldian view of power. The Foucauldian view of power is a better tool of analysis since it reveals and explains more features of "property", including the way that a Lockean conception of property and power, as a point of authority, affects the discourse of property itself. Using a personal and an historical example of the private/public distinction, I establish that these are relational terms built up by various rules of inclusion and exclusion, not upon any prior ground. In particular, I highlight how the production of knowledge functions as one of the conduits in or out of domains; that is, the public and the private are domains of expertise or authority on property. Individuals occupy subjectivities available within the discourse of property which position them, or allow them to position others, as having legitimate or illegitimate relations to property. I show how these subjectivities are the central functional feature of the possibility of normativity. That is to say, whether and how forms of property relations can be evaluated depends on the production of forms of judgment which a subject position makes possible, in form and in content. I ask how present subject positions within the domains of tangible and intangible property work to extend or delimit these domains as moral, political or economic ones. The possibilities of judgment and of freedom from judgment as formal strategies of 4 distinct regimes of power are enumerated, offering an evaluative framework. I ask what, in the domain of property, these 4 regimes offer as formal possibilities for freedom, fairness, and equality. Lastly, I explore Deleuze's concepts of the rhizome and the arborescent with a similar view to reading property as a question of one kind of line rather than another. Finally, I generate from this critical cartography, and bearing in mind the examples of pregnancy and potlatch, a number of responsible strategies one could make from the subject positions identified. 


\section{ACKNOWLEDGEMENTS}

I would like to thank the members of my advisory committee, Dr. James Wong and Dr. Allison Weir, and my external examiner, Dr. Gary Genosko for their time and efforts. This thesis would not have seen it through to defence without the hard work and deep friendship of my advisor, Dr. Jay Lampert. Thank you also to Dr. Elizabeth Boetzkes for her support early on in the process, and to Dr. Barry Allen who read a very rough, early draft and provided some helpful comments. Dr. Theresa Man Ming Lee's faith in my teaching skills gave me the opportunity to focus on some key texts and themes. Mani Haghighi gets full credit for putting me onto Deleuze. Doug Minett gets credit for a special, timely brand of friendship. And I am grateful to Mani, Cézanne and Kuusta for punctuating my years of writing with love and fun. 


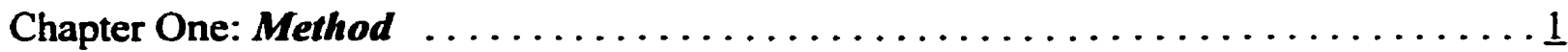

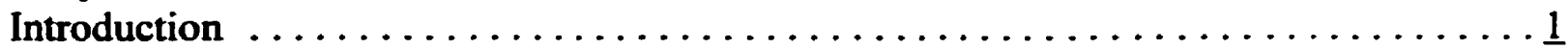

The significance of the institution of property $\ldots \ldots \ldots \ldots \ldots \ldots \ldots \ldots \ldots \ldots \ldots \ldots \ldots$

The variance of "property": conceptual and actual types $\ldots \ldots \ldots \ldots \ldots \ldots \ldots$.

Options for scholarship: historical/anthropological (descriptive and explanatory), or

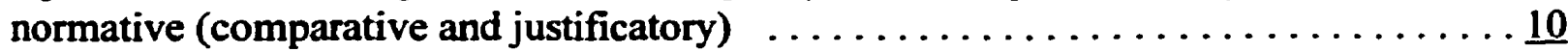

Descriptive Analyses: Histories and Anthropologies of Property $\ldots \ldots \ldots \ldots \ldots \ldots \ldots \ldots$

Strengths of Descriptive Analysis . . . . . . . . . . . . . . . . . . . . . 11

Shortcomings of Descriptive Analysis; How Critical Ontology Compensates . . . . 17

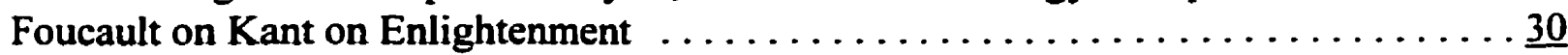

Summary of Descriptive Method as Evaluative Scheme for Property . . . . . . . 35

Normative Analyses: Ethics and Politics of Property $\ldots \ldots \ldots \ldots \ldots \ldots \ldots \ldots \ldots \ldots \ldots \ldots$

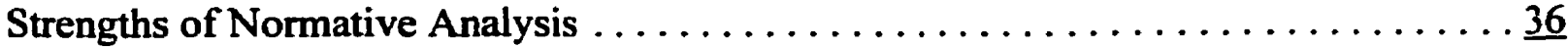

Shortcomings of Normative Analysis; How Critical Ontology Compensates . . . . 36

Normativity and Plurality $\ldots \ldots \ldots \ldots \ldots \ldots \ldots \ldots \ldots \ldots \ldots \ldots \ldots \ldots \ldots \ldots \ldots, \underline{38}$

Normativity and the Manifold Installation of Value $\ldots \ldots \ldots \ldots \ldots \ldots \ldots \ldots$

First bias: The view that normative analysis is free of metaphysical "trappings" . . . . 49

Second bias: Privileging institutions of knowledge as truth-bearers and sites of

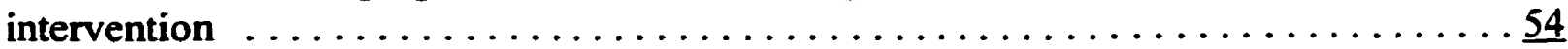

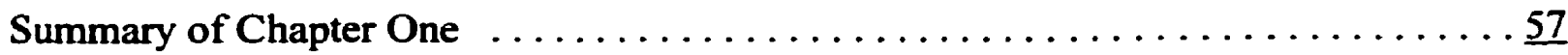

Chapter Two: Power ..............................

A Foucauldian Microphysics of Power: General Elements of Discursive Production ․ $\underline{63}$

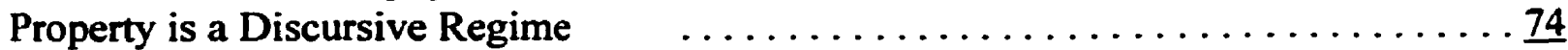

Filmer and Locke on Power, and the Creation of Property. . . . . . . . . . . .

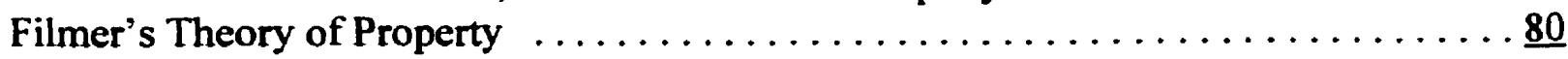

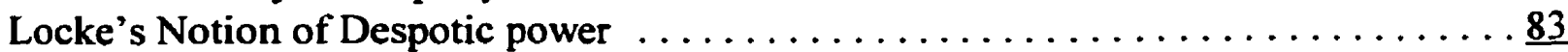

Locke's notion of Paternal Power $\ldots \ldots \ldots \ldots \ldots \ldots \ldots \ldots \ldots \ldots \ldots \ldots \ldots \ldots \ldots$

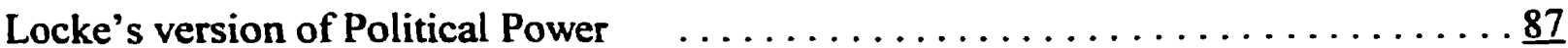

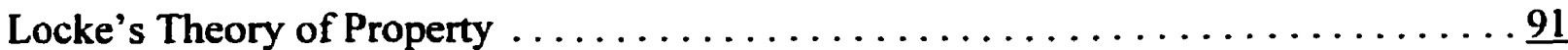

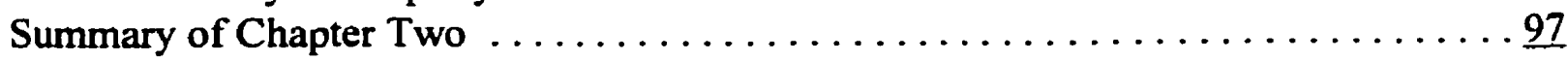

Chapter Three: The Public and The Private ...................... 99

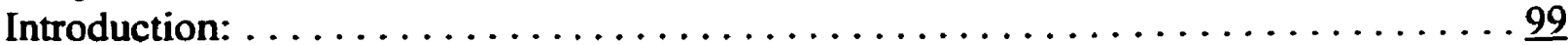

The Public and the Private: Politics, Property and Dividing Practices $\ldots \ldots \ldots \ldots \ldots$

Part One: The Natalist Series . . . . . . . . . . . . . . . . . . . . . . . . 106

A: "Public" and "Private" Do Not Designate Distinct Spaces ............. 110

B: Public and Private Do not Designate Distinct Relations between Persons. . . . 116

C: Bodily Attributes Do not Designate the Private or the Public $\ldots \ldots \ldots \ldots \ldots \underline{122}$

The Body is the House of the Soul, which is therefore Most Private $\ldots \ldots \ldots \ldots \ldots 123$

The Private inheres in Bodily Comportment $\ldots \ldots \ldots \ldots \ldots \ldots \ldots \ldots \ldots \ldots \ldots \ldots \ldots \ldots$

The Public and the Private Cannot be Distinguished according to Distinct Sets of

Activities. . . . . . . . . . . . . . . . . . . . . . . . . . . . . 
G. Are There Essentially Public Activities? $\ldots \ldots \ldots \ldots \ldots \ldots \ldots \ldots \ldots \ldots \ldots$

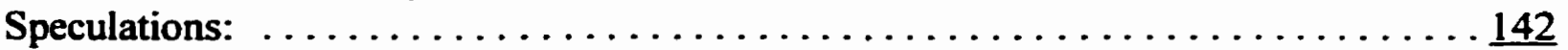

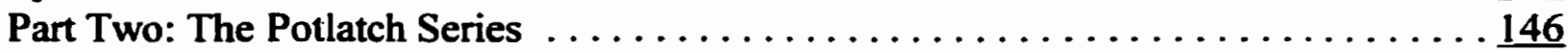

Six General Features of Potlatch Economies $\ldots \ldots \ldots \ldots \ldots \ldots \ldots \ldots \ldots \ldots \ldots \ldots \ldots$

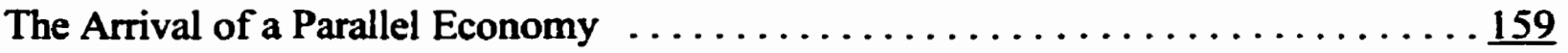

Shifts in the Features of Potlatching Cultures $\ldots \ldots \ldots \ldots \ldots \ldots \ldots \ldots \ldots \ldots \ldots$

Summary of Potlatch Economy Transition: The General Forces of Discursive

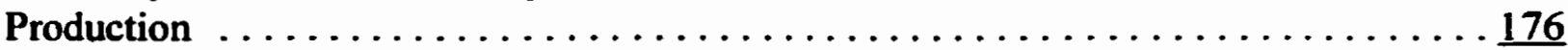

The Knowledge Condition: Subjectivity and Authority $\ldots \ldots \ldots \ldots \ldots \ldots \ldots \ldots$

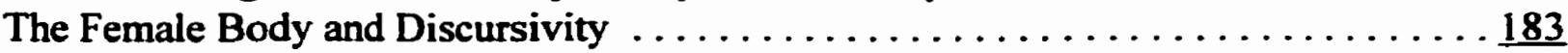

A Return to Natality: Authority and The Visibly Pregnant Female Body . . . . $\ldots \underline{192}$

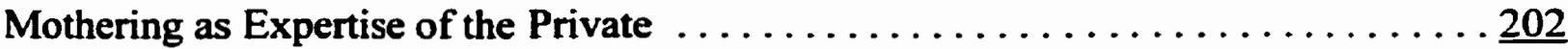

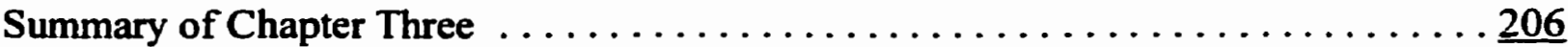

One Last Note about the Relationship of Liberal Theory to The Public/Private Divide

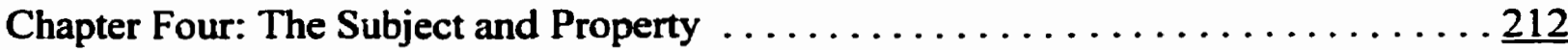

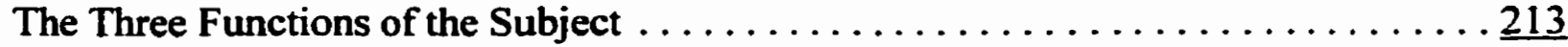

An Expanded Role for the Subject Suggested by the Limits of Traditional Justificatory

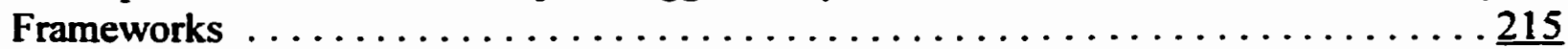

First Function of the Subject: Normative personae which organize and rank persons

The production of sovereign subjects of tangible property. Their significations and techniques for identification or attribution $\ldots \ldots \ldots \ldots \ldots \ldots \ldots \ldots \ldots \ldots \ldots \ldots \ldots \ldots$ The Sovereign Subjects of Intangible Property: Signification and Techniques for

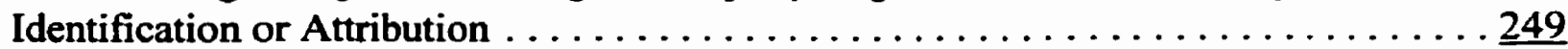

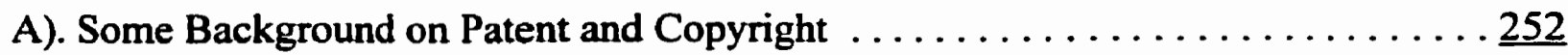

B). The set of economic-utility assumptions, their sovereign subject $\ldots \ldots \ldots \ldots 258$

C). Ontological presuppositions behind copyright $\ldots \ldots \ldots \ldots \ldots \ldots \ldots \ldots \ldots \ldots \ldots \ldots$

D). The Expression of the Idea vs. The Idea itself $\ldots \ldots \ldots \ldots \ldots \ldots \ldots \ldots \ldots \ldots \ldots$

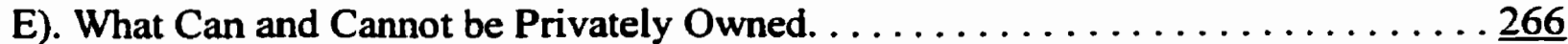

Second Function of the Subject: Moral concerns and their sovereign subjects . . . 271

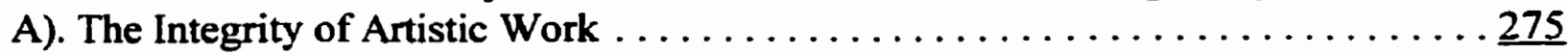

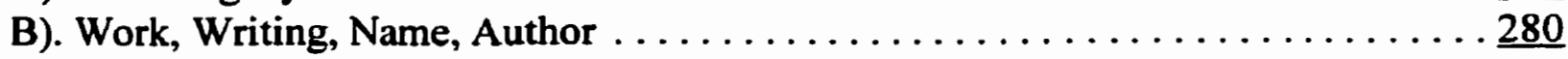

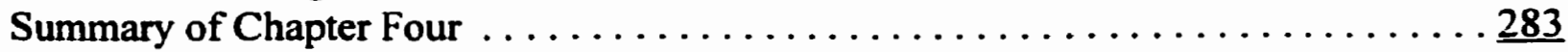

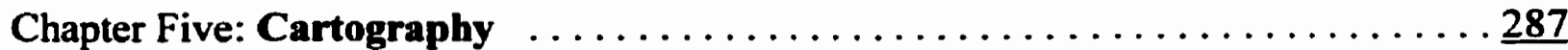

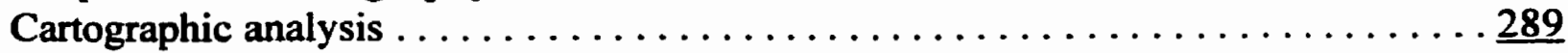

Third Function of the Subject: The Subject and Cartography . . . . . . . . 291

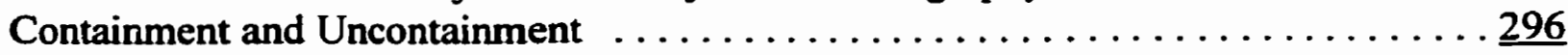

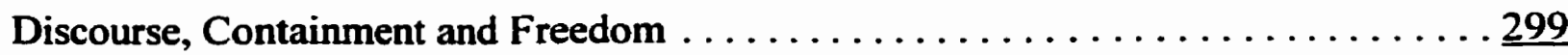

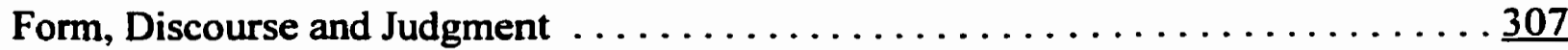

Freedom From and Freedom To: Resistance and Subjectivity $\ldots \ldots \ldots \ldots \ldots \ldots$ 
Cartographic Analysis of the Formal Features of Foucault's Regimes of Power $\ldots \ldots \underline{313}$

Early power regime formation: The Territorial Segment $\ldots \ldots \ldots \ldots \ldots \ldots \ldots \ldots$

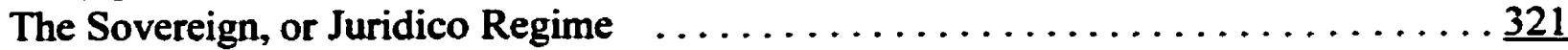

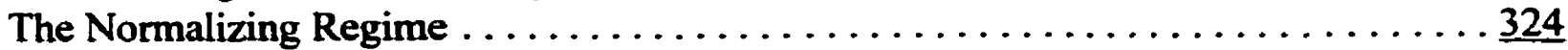

The Regime of Biopower . . . . . . . . . . . . . . $\ldots \ldots \ldots \ldots \ldots$

Forms of Power and Intellectual Property: Analysis . . . . . . . . . . . 339

Primitive Territorial Segment: Uncoded (Non-Property) Transmission . . . . . . 340

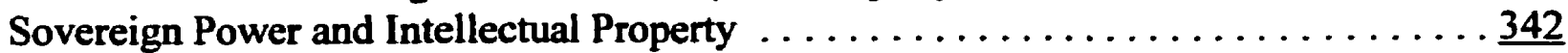

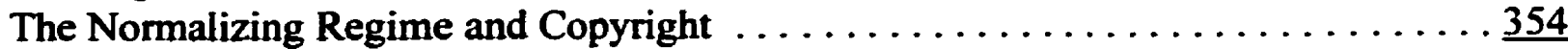

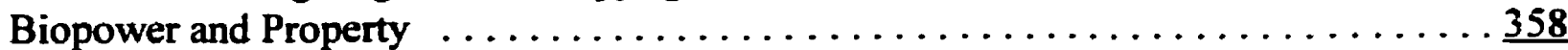

Tentative Conclusion from Foucauldian Cartographic Analysis . . . . . . . . 360

Deleuze as Critical Cartographer: Rhizome and Arborescent Lines . . . . . . . $\frac{361}{362}$

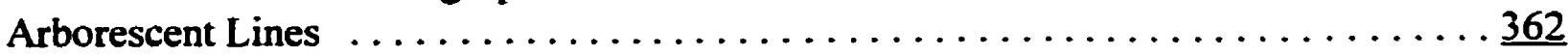

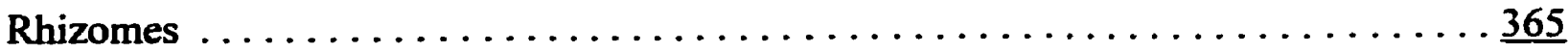

Deleuze's EthicoOntological Evaluation: Rhizome and Becoming $\ldots \ldots \ldots \ldots$

Intellectual Property Schemes as Lines . . . . . . . . . . . . . . . . 370

The Specific Intellectual, the Philosopher: Arborescent Theory and Practices. . . 373

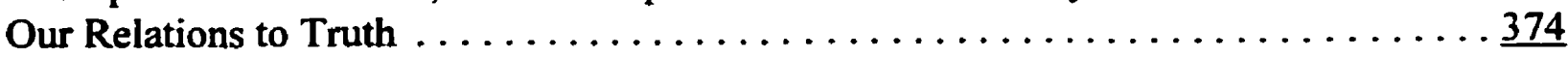

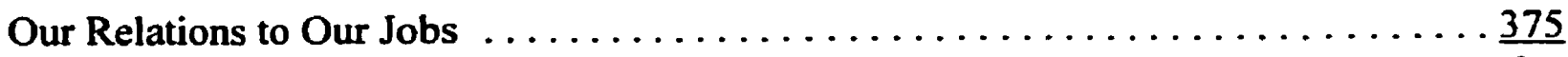

How to move the intellectual toward rhizome/becoming: what methods and practices of

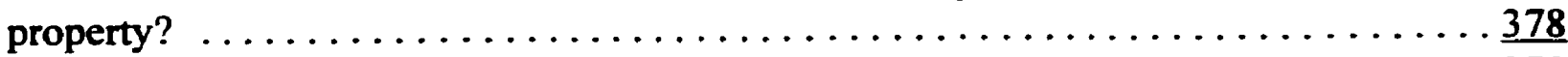

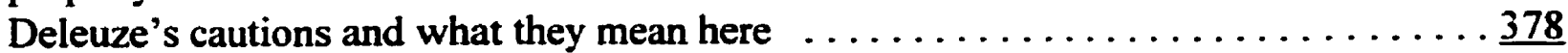

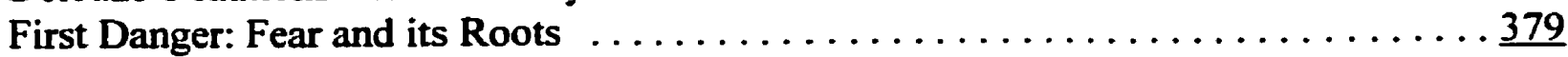

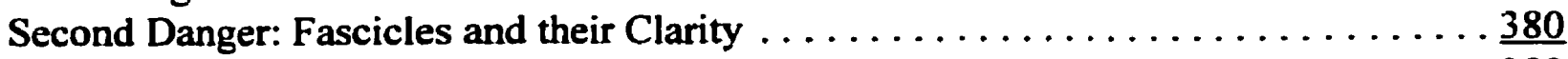

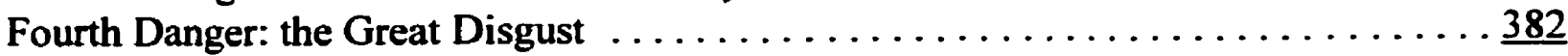

Free Thinking: Intellectuals at a Potlatch? . . . . . . . . . $\ldots \ldots \ldots 3$

Conclusion: What cartographic analysis has gained for our understanding and

responsibility to intellectual property: . . . . . . . . . . . . . . $\ldots \ldots \ldots$

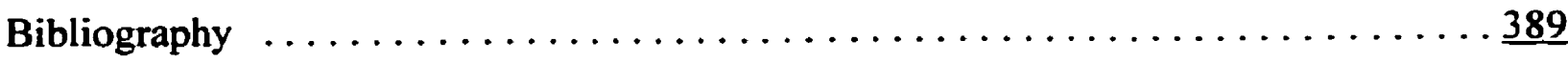




\section{Chapter One: Method:}

\section{$\underline{\text { 1. Introduction }}$}

In this chapter, I seek to establish an evaluative scheme appropriate to the concept of property. What kinds of methodologies have been used? What kinds of methodologies have not yet been tried? Which ones ought to be adopted for this task?

Orthodox descriptive accounts sometimes fail to directly address the ethical and political questions which property asks. Descriptive analysis sometimes fails to grapple with how its own values inform its descriptions. This can uncouple a scholar's understanding of how her own intellectual work extends or disrupts a narrative from the narrative that she is producing. A schism between scholarly activities and what she would be prepared to commit to in her "real life"may be fostered. Some kind of normative account is needed, but traditional normative frameworks can fail for the same sorts of reasons. Both traditional approaches can leave a gap between what one thinks about property and what one does about property because both fail to adequately involve the one who is doing the thinking or describing. More pointedly, they do not adequately (conceptually and methodologically) integrate activities like thinking or describing with activities like owning or selling. I write this from my experience of years of surveying historical and normative accounts of property.

One way to remedy this is by using a Foucauldian-inspired "micropolitics of 
property".' Micropolitics suggests that property is a central feature of social life, human and non-human, because it is linked with power. Power is involved not only in the creation and distribution of property, but also the conceptual grid which undergirds theories and practices involving property. This kind of critical work uncovers ontological commitments - "the fact generating practices" - supporting particular conceptions and forms of property. It is also self-reflexive; that is, it sees a dialectical relation between the one who writes about or studies property from a particular subject position, the values (personal and cultural) which authorize those observations, and the kinds of objects and problems which can be seen as property-related, from such a position.

\section{The significance of the institution of property}

Property is central to society and culture. It is a fundamentally social institution. It is endemic to all human and to many non-human cultures. ${ }^{2}$ Variations in practices of property -- creation, marking, acquisition, possession, destruction and transfer -- are

Another fruitful remedy would be to use feminist work on subjectivity and situated knowledge which responds to many of the same concerns that l express in this chapter. See for instance Lorraine Code's Rhetorical Spaces: Essays on Gendered Locations, New York, Routledge, 1995. The main difficulty with making direct use of feminist work in the area of property is that situating women as historical and normatively authoritative subjects from where women speak gains for projects of epistemology but not necessarily for projects of property. This is because, on the one hand, stronger conceptual links between power/knowledge/owning have not yet been forged, let alone fair socioeconomic distribution of orthodox ownership relations across gender accomplished, but, on the other hand (as I show in chapter three) the uptakes of certain key female situated subjectivities may have an unfortunate role in extending the relations of power which keep those links and distributions from happening.

2

Konrad Lorenz. On Aggression. Trans. Marjorie Kerr Wilson. New York: Harcourt, Brace and World, 1966; Eibl-Eibesfeldt, Irenaus. Ethnology. Trans. Erich Klinghammer. New York: Holt, Reinhart and Winston, 1975; Gilles Deleuze and Felix Guattari, "1837: Of the Refrain." A Thousand Plateaus. Trans. Brian Massumi. Minneapolis: University of Minnesota Press, 1987: 310-350. 
manifest. Not merely a sequence of automatic, natural behaviors, ${ }^{3}$ these property

practices are undergirded by some conception of property and stabilized by some

normative or value framework, either explicitly held or implicitly displayed in those

practices. This happens in the following way: Normative frameworks prescribe and

stabilize one variant among others. One property variant expresses and makes available to

a culture desired values or state of affairs, or represses and prevents the circulation of

undesirable values or states of affairs. Actual property practices prescribe and stabilize

certain variants among a wide range of possibilities in a given society. That there is some

evidence of choice among, change over time, and critical reflection across, variants in

property practices suggests that property is deeply social.

Further, property is linked to power; it is perhaps even a form of power. Property

Many have posited that property practices, communal or private, are the upshot of some "natural" cause or base premise, such as: willful self-preservation (Letourneau, 1892); an instinct for gathering or possessiveness (Macpherson, 1962); the instinct for violence against others expressed as theft, destruction and usurpation (Hobbes, 1651; Lafargue, 1975); a human instinct toward creativity and industriousness (Locke, 1690); a naturally established link between bodily effort and exclusive possession (Smith, 1853); a natural right of ownership in one's body (Locke). However, the expression of any of these is precipitated by the social, by being among others with (presumably) similar "natural" needs and motives.

Cf. Karl Marx: "In the social production of their life, men enter into definite relations that are indispensable and independent of their will, relations of production which correspond to a definite stage of development of their material productive forces. The sum total of these relations of production constitutes the...real foundation, on which rises a legal and political superstructure and to which correspond definite forms of social consciousness. The mode of production of material life conditions the social, political, and intellectual life process in general. It is not the consciousness of men that determines their being, but, on the contrary, their social being that determines their consciousness." in "Author's Preface to A Contribution to the Critique of Political Economy. "Karl Marx: Selected Writings. Ed. David McLellan. Oxford: Oxford University Press, 1977:389. However, Marx's general historical overview of primitive communism to private property, and (after the communist revolution) back to a common property system once again, is not easily squared with his materialist account (above) where modes of production (rather than "natural" causes) "determine" or "condition" social possibility, including the sustainability of particular work and ownership relations or their propensity for change. Andrew Reeve and Jack Lively. Modern Political Theory from Hobbes to Marx: Key Debates. New York: Routledge, 1989; Andrew Reeve. Property. Atlantic Highlands, N.J.: Humanities Press International, 1986. 
and power are often interchangeable: those with the power to amass, create relations of debt and exchange around, or dispose of property are often the ones who have more power. The distribution of power (the power or lack thereof to create, appropriate, mark, hold or transfer) is at the core of what we understand by the political and political economy. There are also rich connections between property and the personal or personal identity. ${ }^{6}$ Real property systems are interwoven with political, personal and philosophical systems. All touch on the very important issues of power, survival, identity and social justice. Property is "fundamental to social life, whatever form [it] takes...providing links between an economic system, a legal system, and a political system. ${ }^{\text {in }}$

\section{The variance of "property": conceptual and actual types}

The forms, purposes, objects, forces and codes (legal, administrative, moral, linguistic) of property are remarkably varied. This is true both of anthropological and historical variance. What is readily recognized and "handled" in a North American capitalist democracy as a familiar form of "property" is not necessarily the same object,

The variants in property systems are so remarkable that positions in systems which appear to us be polar opposite, can be said to be positions of equal status. In Western capitalism, amassed personal wealth and power are co-indexed, while among some of the North American West Coast Indian tribes (Kwakiutl, Salish, Tshimshian, Haida), the most powerful position is held by the one who has squandered or leveled the most amount of personal wealth. Helen Codere, Fighting with Property. University of Washington Press: Seattle, 1966: 75-76.

6

Reeve (1986:5) reminds us that there is an emotional and psychological dimension to ownership -something akin to belonging and attachment, self-knowledge and personality -- which are terribly important to many people's sense of well-being. Sometimes, this only becomes visible as a dimension of the meaning(s) of property when one's belongings are stolen or defiled.

7

Reeve (1986:7). 
event, or set of conditions recognized as "property" in another culture." In reference to the

Samoans, Marcel Mauss writes,

...what they exchange is not solely property or wealth, movable and immovable goods, and things economically useful...[but] acts of politeness, banquets, rituals, military services, women, children, dances, festivals, and fairs...9

This variance is apparent not simply across the two primary forms of property, "private" or "public". There is extensive variance internal to each of these two as well. ${ }^{\circ}$ Similarly, even within a relatively well-demarcated cultural tradition, the objects properly considered to be property -- acquirable, possessible and transferable -- have shifted over time, sometimes quite rapidly." This is true as well of the subjects within systems of property: those persons or offices considered to be legitimate, to warrant socially recognized and supported roles in marking, acquisition, possession and transfer. Subject positions include the claimant and the parties against whom property exclusions and liabilities could be claimed. ${ }^{12}$

Renée Hirschon, ed. Women and Property - Women as Property . London: Croom Helm, 1984.

9

Marcel Mauss. The Gift: The Form and Reason for Exchange in Archaic Societies. Trans. W.D. Halls. New York: Norton, 1990.

10

Reeve (1986:44) suggests that these categories are so rich, and their forms so subtle that on occasion, forms of property could be said to occupy a conceptual position which is neither private nor communal.

11

M.I. Finley. Ancient Slavery and Modern Ideology. Penguin, 1980; Lee Holcombe. Wives and Property: Reform of the Married Women's Property Law in Nineteenth-Century England. Oxford: Martin Robertson, 1983.

12

S. F. C. Milsom. Historical Foundations of the Common Law. London: Butterworths, 1969. 
Presumably, the forms, objects, subjects and codes of property will continue to shift. In the modern Western tradition, the three most stable $\mathrm{e}^{13}$ kinds of property inhere in the tangible: in land (territory), in movable things (material belongings) and in the body (physical self). Newer, surprising and category-resistant forms of ownership continue to emerge. One example is intellectual property -- ownership of ideas and their innovations. This is an intangible form of property. It has in fact been recognized as property-related in many cultures for the better part of the last millenium. ${ }^{15}$ But, perhaps by virtue of the exponential growth of information technology, it has recently gained a much more prominent position in the global discourse on property. "Intellectual property" is a prime element in the establishment of rightful claims to indigenous knowledge. These claims are and will continue to be a major factor in the use of plant, animal and human species: the patenting of living beings who carry treasured information, and the economic rights of those who have this kind of knowledge, or access to the means to register this knowledge as private, not public domain. Our positions as intellectuals in universities is complicit in a system of rights and responsibilities regarding this kind of property. However, the prominence of intellectual property as a mode and as a set of questions about property is

Even the word "stable" is culturally specific and needs careful qualification. Where we might tend to call "fixed property" that which physically stays in one place, or which doesn't switch hands frequently, (if at all), and having a quasi-permanent owner-owned relation, the Samoans call "fixed property" that whose destination doesn't change, even though it changes hands ("owners") frequently. A child can be given, interfamilially, yet not as a possession, but as a bearer of a stable property (the maternal or paternal name) which needs this rearrangement in order to allow the fixed belonging to flow properly toward its destination. (Mauss, 1990:9)

14

Ronald V. Bettig. Copyrighting Culture: The Political Economy of Intellectual Property. Boulder, Co.: Westriew Press, 1996: 9-32. 
more than simply a spinoff of technologies which can access and spread knowledge quickly and massively around the globe; that is, it is more than merely an accident of technical means and competence. Its emergence is related to shifting ethicopolitical codes and forces. I will return to this point.

A second and related "new" form of property which is increasingly feasible for traffic and profit is the non-lethal removal and sale of human body parts. Among populations of the world's poorest people, from the Persian Gulf to China, the sale of corneas and kidneys has become a feasible and not uncommon money-making choice. ${ }^{15}$ Again, the sale of human body parts is more than the benign extension of new medical technology which can accomplish the removal and safe transportation of human organs. It is supported by recent shifts in thinking about such ventures, the intersection of material and conceptual opportunity.

A third and final example of emerging variance in real property suggests itself from the "space program": Within the last two decades, outer space and other planets, especially Mars, have joined Earth as potential locales of the not-yet-appropriated. ${ }^{16}$

Charles P. Wallace, "For Sale: The Poor's Body Parts." Los Angeles Times 27 Aug. 1992: A 1; Dimitri Chubashenko, "Illegal Sales Abound in Moldova." Globe and Mail 28 Oct. 2000: A25.

16

In 17th and 18 th centuries sophisticated property theories (including those of Locke and Pufendorf) there was an ontological status accorded to the not-yet-appropriated. The not-yet-appropriated (therefore the still-for-the-taking) played a pivotal justificatory role distinguishing legitimate from illegitimate private property acquisition via the notion of "original acquisition". Clearly, this legitimation only "applies" where the acquisition is original, that is, of non-settled (or what is taken to be non-settled) territory. Space exploration as property venture (in light of global overpopulation) appropriates this same notion. John A. Simmons, "Original-Acquisition Justifications of Private Property." Social Philosophy and Policy 11:2 (Summer 1994):63-84. Simmons specifically invokes the spectre of humankind's future on Mars. 
This is not just an hypothesis of science fiction. These new forms of property are interesting; however, they are more than curiosities, inevitabilities, or benign forms of human existence realized technologically.

This is because in addition to the enormous multiplicity that property illustrates at the level of the actual, (past, present and future), there is enormous variety in the conceptual (linguistic, valuational, ideationaly and theoretical) dimension of property. The conceptual domain involves that which is known, said, thought, desired, feared, understood and imagined about a given set of ideas, such as ideas about ownership. What that domain is composed of at any given time and place can be brought to bear, formally or informally, on aspects of property in order to describe, challenge, endorse or justify certain forms, purposes and relations of property over others. The range of conceptual possibilities regarding property is one place where culture and personality are expressed.

The conceptual bases which undergird the varied practices of property across time and culture are as polyvalent as its actualizations. They, too, have shifted historically and anthropologically, and there is no reason to believe that they won't continue to do so. To take just one example: one prominent 16 th and 17 th century political view on property, which Robert Filmer defended in his famous work Patriarcha (1680), argued for the continuance of exclusive aristocratic holding and royal primogeniture entail: the "indivisible beam of majesty" from God, through Adam's sons and the sons of Noah, to the heads of the feudal kingdoms of the world. ${ }^{17}$ This view was being challenged by a 
radically reconceptualized notion of property which held that the true establishment of private property occurred through the labor of the non-enfranchised individual, rather than by blood right. ${ }^{18}$ The Filmerian conception of ownership in land lost footing to these latter (Lockean) views, especially in the "New World", roughly in concert with broader social and political changes in the direction of democratic liberalism. However archaic Filmer's arguments appear to my middle-class, North American, $21^{\text {st }}$-century viewpoint, Filmerian-type arguments may still be successful among cultures presently organized according to feudal, monarchical or aristocratic rule, and may even take up position again in Western culture, depending upon how future politics, economics and law play themselves out. It is not easy to imagine a democracy reverting to feudal holdings, but it isn't an impossibility. Democracies revert to military rule, and these often reinstate old lines of patriarchal power.

To sum up: conceptual and the actual domains of property are marked by fluidity and multiplicity. Real changes in cultural property practices are accompanied by changes in the imaginational, theoretical, and linguistic systems which undergird those actual changes. Many have argued that it is the conscious and the imagination which drive changes in the material real practices of property, while others have argued that changes in the material real drive changes in the categories of thought and belief. Still others have argued that neither is prior to the other, but that the society is nothing other than the 
system of conceiving, desiring, marking, acquiring and circulating. ${ }^{19}$ A study of property, then, must examine the interplay of these domains.

Options for scholarship: historical/anthropological (descriptive and explanatory), or normative (comparative and justificatory)

My two preliminary claims: 1) that property is crucial to social function, central to power and social justice insofar as it is an indispensable condition of social life; and 2) that property, conceptually and actually, is polyvalent, pose this challenge: What should scholarship in property consist of? Which sort of approach takes account of both its significance and its polyvalence; that is, is evaluative and yet non-reductive? What kind of scholarship is equipped to address property's conceptual and material polyvalence; that is, does not privilege the theoretical over the material, the historical over the present, or vice-versa? A study of property is typically undertaken either as scientifically-modeled research and documentation, in the form of history, sociology and anthropology of property, or, as normative evaluation, in the form of political or ethical theories. I will look at each of these disciplinary possibilities in turn, in order to see whether, and to what extent they are able to satisfy the challenges identified. After this, I will identify a third possible approach to property -- micropolitical analysis, (discursive analysis, genealogy and critical ontology) -- which seems to avoid the limitations of these two main kinds of study while retaining their positive aspects. 


\section{Descriptive Analyses: Histories and Anthropologies of Property}

One viable option for scholarship on property is to research and document its material variance. This is classic descriptive work: the "histories", "sociologies" and "anthropologies" of property.

\section{Strengths of Descriptive Analysis}

There are two main strengths or appeals to studying property from disciplines like history, sociology, and anthropology. The first appeal lies in the positioned primacy of material reality. The second appeal lies in a purported commitment to value-neutrality, to working against (or in the absence of) investigative bias. This second strength, on closer examination, proves to be, at best, a naive one. And the direction for critical scholarship that the first leads us toward is countered by the principles inhering in the second.

One of the most compelling reason for working on property from a descriptive "scientific" base lies in the potential for non-theoretized subject matter to make any study a rich one. Since the domain of property is already multifaceted, then perhaps a study of property which attends to the "what" and the "how" is not so much "richer" as "truer" to its subject matter. However, there is more to this appeal than an aesthetic value ("richness") and a good fit between method and subject. Documenting regional variance in property systems over time, over an almost unimaginable number of material possibilities and between real persons, promises to guard against reductionism. The particular, the singular, is less hospitable to totalizing narratives than the abstract is. A researcher's awareness of the historical (contingent) dimensions of his/her subject matter can cultivate an awareness of his/her own constrained placement within history. This 
sometimes can mean less dogmatic scholarship..$^{20}$

I believe, however, that there is something even more compelling than a promissary note about less dogmatism. The experience of a vast and complex subject matter's resistance to summary and containment can change the terms of engagement between the researcher and his subject matter. Unfortunately, there probably is something about the "abstract" which makes "human beings not particularly involved in what they are." ${ }^{21}$ For scholarship, the abstract is a "view from nowhere" about "nobody in particular", a positioning which can disengage the researcher from what they are, when they are a researcher, what they are doing when they are doing research and who, or what they are doing this to. Further, it removes the very corcrete individual from having to reflect upon the other concrete individuals whose non-abstract work makes that research activity possible. ${ }^{22} \mathrm{~A}$ close examination of the concrete and regional such as is typical of anthropological and historical research makes possible a more politically sensitized understanding of the subjectivity of the investigator, the subjectivity of the

Hirschon suggests that without an understanding of the historical context which has framed "property" in the West in the particular forms we know it as, any arguments (economic, political, ethical) "in favour of" or "against", say, private ownership will be both arrogant and unhelpful. C.B. Macpherson, Property: Mainstream and Critical Positions. Toronto: University of Toronto Press, 1978. suggests that support for modern property is based upon "flawed assumptions" about human possessiveness. Reeve (1986) suggests that an appreciation of the variance of property schemes lays bare even the most rudimentary assumptions to critical reflection, such as "why anyone should be thought to own anything at all, why property of any kind is desirable...?"(1984:4).

21

Tracy B. Strong. Foreword to The Concept of the Political. Carl Schmitt. Chicago: University of Chicago Press, 1996:xvii.

22

Dorothy E. Smith, "Women's Perspective as a Radical Critique of Sociology." Feminism and Methodology. Ed. Sandra Harding. Bloomington: Indiana University Press, 1987: 84-96. 
investigated, and the way these are inextricably linked. One's disciplinary or

methodological commitments ought not to prevent this awareness and the sensitivity which can follow from it. Histories and anthropologies do not, content-wise, demand this self-reflexivity, but they don't forbid it. If anything, their forms of inquiry seem ideally conducive to it. The first appeal of working on property descriptively involves its material basis and the kinds of potential that this offers for politically sensitive work .23

A second oft-cited appeal of studying from an historical or an anthropological, rather than from an expressly normative position, lies exactly in a purported neutrality. The belief that descriptive scholarship alone can produce the desirable quality of documenting the origins and displays - the facts - of actual property practices without imposing moral judgement about them, is a strong one. It is also considered by many to deliver political sensitivity. Indeed, it is both desirable and intellectually respectable to avoid using the platform of knowledge-making to insert political or religious ideals under the guise of objective scientific research. "Sociology...as science... was to be a way of escaping bondage to past and present loyalties." 24

When I speak of the potential of the empirical to make scholarship "richer" and less "dogmatic" I mean philosophically richer: a) where the sensible is not necessarily reduced to the abstract, (or vice-versa); or, b) where one is not posited as necessarily primary and the other secondary (as, for instance, the primacy of "reason" over "experience"). This is the point of the degree of material plurality that one sees in the work of Deleuze and Guattari. For extended critical discussion of Deleuze and Guattari's "transcendental empiricism" see Bruce Baugh, "Deleuze and Empiricism." Journal of the British Society for Phenomenology 24:1 (January 1993):15-3I; Constantin V. Boundas, Introduction to Gilles Deleuze. Empiricism and Subjectivity: An Essay on Hume's Theory of Human Nature. Trans. Constantin V. Boundas. New York: Columbia University Press. 1991; John Mullarkey, "Deleuze and Materialism: One or Several Matters?" The South Atlantic Quarterly 96:3 (Summer 1997):439-43.

24

$$
\text { Douglas (1990:xii). }
$$


There are two parts to address regarding the strength of this appeal: one part lies in the purported value or disvalue of objectivity, and one part lies in its very possibility. These are complex, deep questions which have been argued extensively elsewhere. ${ }^{25}$ I haven't the space to rehearse the arguments here. I will make just a couple of comments in light of my question about property and method.

First, even if it were the case that positivisitic, value-free science were possible, which I don't think could be confirmed or disputed once and for all, it isn't clear that this would be the most worthwhile form of study. A case can been made for the goodness of science lying in its ability to reflect, rather than to exclude or disavow, cognitive values such as "objectivity". ${ }^{26}$ However, there has been ample evidence of the fact that knowing has emotional and moral dimensions, and as much as it is intellectual work, it is always culturally embedded. ${ }^{27}$ Facts are often morally biased. This would more than likely be the case when studying a subject like property for the very reasons I discussed earlier: it is necessarily a social phenomenon and it is unlikely that the researcher has merely an intellectual curiosity in the subject. It has been argued that the researcher in the field or in

See, for a small sample of the debate: Helen Longino. Science as Social Knowledge. Princeton: Princeton University Press, 1990; The Social Production of Scientific Knowledge. Eds. Everett Mendelson, Peter Weingart, and Richard Whitley. Dordrecht: Reidel. 1977; Alison Wylie, Kathleen Okruhlik, Sandra Morton, and Leslie Thielen-Wilson, "Feminist Critiques of Science: A Comprehensive Guide to the Literature." Resources for Feminist Research 90:2 (1990); Sandra Harding, Whose Science? Whose Knowledge? Ithaca: Cornell University Press, 1991.

26

Thomas Kuhn, "Objectivity, Value Judgment, and Theory Choice." The Essential Tension : Selected Studies in Scientific Tradition and Change. Chicago: University of Chicago Press, 1977.

27

Jürgen Habermas. Knowledge and Human Interest. Boston: University of Boston Press, 1970: 91 -99; Legitimation Crisis. Boston: Boston University Press, 1975: 95-104. 
the laboratory is always more than a one-way neutral registering device: $s$ /he is an informing, thoroughly human collaborator in representation and classification. Fact presented as already-formed fact fails to flag the fact-generating practices informed by cultural schemas.

Facts are made, fabricated, constructed, that observations are not independent of theory....the "explanations" invented as a function of their notion of expectations... ${ }^{28}$.

Pierre Bourdieu, confessing that it strikes him as discouraging and intellectually anachronistic to have to do so, argues that there remains in many disciplines (he is speaking specifically about ethnographical studies) a wide and seemingly tenacious gap between the cognitive register of critical hermeneutics, and that same comprehension brought to bear on one's actual scholarly activity. In the area of property studies, one example is the "data"on property systems found in early 20th-century (largely American, French and German) anthropology. Complex practices of alienability and inalienability in indigenous cultures were categorized and recorded - if they even were recorded -- as "gift-givings"; i.e. as belonging to a different category of cultural phenomena than property. There were serious and real ramifications to this "fact-finding". ${ }^{24}$

Pierre Bourdieu. Afterword to Reflections of Fieldwork in Morocco. Paul Rabinow. Berkeley: University of California Press, 1977: 163-165.

29

In the Pacific Northwest, that the Potlatch was "read" by anthropologists and government officials as gift-giving and seasonal religious ceremony, rather than continuous recurrent commerce, contract and legal negotiation, meant that the Natives practicing these property-forms were seen as pre-civilized, "lawless", "atrocious", irregular, "absurd", anti-accumulation (i.e. stupid and lazy), egotistical, fierce and mean (i.e. anti-social). The potlatch was banned. These cultures no ionger thrive. See: Halliday, Canadian Indian Affairs Annual Report. 1890; 1906; 1909; H.G. Barnett, "The Nature of the Potlatch." American Anthropologist. 40 (1938): 349-358; Margaret Mead, Cooperation and Competition among Primitive Peoples (1 $1^{\text {st }}$ edition). New York: McGraw-Hill, 1937; Helen Codere,"The Amicable Side of Kwakiutl Life: The Potlatch and the Play Potlatch." 
Mauss, Bataille, Levinas, Derrida and others ${ }^{30}$ have revisited the assumptions behind the notion of "gift", sometimes reconceiving the general phenomenon, sometimes showing how the above-mentioned categorizations were the product of the anthropologists' own cultural biases. If gift-giving is conceived of as natural, private, emotional, customary (as in etiquette), and, therefore, by definition, non-reciprocal," these activities will tend to be seen as insignificant to broader cultural mechanisms, as largely incidental to power.

If and where there in an endorsement of historical or anthropological studies of property over more overtly value-expressing studies like political or ethical theory on the grounds of a purported value neutrality this would be especially troubling, for,

What is dangerous is not the presence of value judgments...but only those judgments that remain beyond the reach of critical reflection and are not subject to revision in the light of experience..$^{32}$

I will suggest that what is often posited as a compelling reason for pursuing descriptive

American Anthropologist. 58 (April, 1956):334-350.

30

Alan Schrift. The Logic of the Gift. New York: Routledge. 1997(I refer you to Shrift's extensive bibliography: 327-330); Jacques Derrida. Given Time: I. Counterfeit Money. Trans. Peggy Kamuf. Chicago: University of Chicago Press, 1992; Emmanuel Levinas. Totality and Infinity. Pittsburg: Duquesne University Press, 1969; Georges Bataille. "The Gift of Rivalry." The Accursed Share: Volume 1. Trans. Robert Hurley. New York: Zone Books. 1988: 63-77.

31

G. A. Dworkin. Markets and Morals. Washington, D.C.: Hemisphere, 1977; David Collard, "Blood and the Gift Relationship." Altruism and Economy. Oxford: Martin Robertson, 1978: 140-150.

32

Robert N. Bellah. foreword to Paul Rabinow's Reflections of Fieldwork in Morocco, (Berkeley: University of California Press), 1977: xi-xii. 
analysis -- a "scientific approach" - over other scholarly approaches perhaps should be treated with caution.

Shortcomings of Descriptive Analysis; How Critical Ontology Compensates

There are three potential shortcomings to adopting a primarily descriptive approach to property. These are: 1) silence on the ethical, social and political dimensions of the real property systems it describes; 2) a methodological bias toward placing the researcher and theory "outside" the field of what is studied; and relatedly, 3) the naturalization of conceptual biases, limiting how much we think about our thinking. These three "shortcomings" line up with the three key junctures where values enter scholarly work and where there is also political or ethical blindness. Those are: a) in our study methods: classification, description, comparisons; b) in the degree to which the subjectivity of the researcher as a kind of position is explored for its effects on the study, and the study for its affirmation of that subject position; and c) in our critical reflection of the choice to study our object as an objects of study. Not every descriptive endeavor is guilty of being ignorant of these aspects. However, critical ontology makes these aspects of study central. In giving an overview of his work, Foucault claimed he was guided by two questions in his projects:

The first: At any historical moment, what kinds of conditions come into play in determining that a particular subject is the legitimate executor of a certain kind of knowledge? The second: At any historical moment, what conditions come into play in determining that a particular object is the appropriate object of a particular kind of knowledge ${ }^{33}$ 
In my elaborations of each of these three "shortcomings" I will try to show how and why they are so central.

1. First, recalling that we initially described the domain of property as both variable and critical, it seems less than ideal to be working from a vantage point which permits itself to opt out of making evaluations among, and suppling alternatives to, the practices it describes. ${ }^{4}$ Although I don't think it's simply morally wrong for anyone to study property without taking a stand, I think that it is morally wrong not to reflect on the possible meanings of, or ramifications of a course of study, for oneself and for the world being described. Scholarship on property ought to take a stand on its subject matter, or at the very least, put one in a better position to be able to make critical comparisons among variants. Although there are serious cautions to be made about taking a stand, this is not the same as saying that evaluation and critical judgement ought not to play some kind of important role. I believe it must.

The variance we see and experience in actual property systems is partly the result of the differences in the way values like "beauty" and "utility" are played off against one another, when someone takes a stand. Identifying where those values are being played out "in" scholarly activity identifies points for addressing these critical aspects of property.

xiv. Faubion is commenting on the entry that Foucault wrote, for Dictionnaire des philosophes under the pseudonym "Maurice Florence". The entry, translated by Robert Hurley, is in The Essential Works: 459-463.

34

A typical example can be found in F. H. Erbish. and K.M. Mareida. Intellectual Property Rights in Agricultural Biotechnology. New York: CAB International, 1998. This recent book contains highly detailed descriptions of the laws and legislations about agricultural biopatenting around the world, without framing any of the socioethical issues around biotechnology, except for some concerns about economic loss related to treaty non-cooperation, and legal means to recoup infringement. 
There are two ways in which the subject matter, the "actual" distribution of power (such as who owns or can own land, and who does not or cannot), can be affected by academic work. The first, the more obvious way, is where such analysis is seen as for, or as quite possibly leading to, direct reconfiguration in the world. Examples include: research which could be used to identify and prioritize particular group interests, revisions of treatises, laws and codes, etc., any number of direct, practical interventions. All too often, the scientific disciplines -- history, comparative law, anthropology and the like - are reticent about admitting these links, let alone directing the ways those links ought to be made. These disciplines often leave the responsibility for making recommendations from their findings to others. Indeed, the distinction between "pure" and "applied" sciences implies that it is perfectly acceptable, if not more desirable, that no concrete changes will emanate from the findings. Where these practical changes are socially significant this sort of neutral disavowal seems unacceptable. Since things actually are done as a result of research, a bizarre schism between a scholar's commitment to her "work" and what she would never be prepared to commit to "out in the real world" is enabled. ${ }^{3 s}$

As I see it, the problem with these schisms is that they decrease the chance that researchers will reflect more critically and more broadly on the ramifications of their work, and make adjustments accordingly, even if those "adjustments" amount to admitting such connections. They are the ones who are looked to for confidence or for cautions, about the work itself. This schism, then, only accelerates science and scientism; it never decelerates, polices, or radically cautions itself from within. A striking example (to my mind) is found in Francis $\mathrm{S}$. Collins, the chief director of the Human Genome Project. Colin, in biographical remarks, claims that he is a strong Christian, firmly against abortion. Yet, it takes no imagination to see that increases in prenatal testing (the first diagnostic upshot of gene mapping) will directly lead to increases in prenatal abortion (the only presently available "therapy" which can respond to the medical information revealed by the prenatal testing). "Where Science and Religion Meet." Scientific American (Feb. 1998):28-29. Hans Jonas (The Imperative of Responsibility. Chicago:University of Chicago Press, 1984:120-123; 166-169) makes a very strong case for the value of, and yet the relative absence of, caution in scientific methodology. 
Besides policy or action-based intervention, there is another way in which scholarship, no matter how far removed from the possibility of social application, can be political.

Actual acts of research, writing, thinking are themselves the culmination of a specific array of values (economic, class, gender...) made real, at specific moments involving specific persons and as a certain kind and location of investigation and therefore compose nodes of resistance.

Where there is power, there is resistance, and yet, or rather consequently, this resistance is never in a position of exteriority in relation to power. ${ }^{36}$

There is an initial distribution of power between nodes in which research takes place: the intellectual, and the "objects" of research, the social. This is a power relationship. It is unequal. It is created and stabilized by the material conditions which put one in the position of watcher and one in the position of surveyed, and by a lack of reflection about those relationship, a point of pride for some academic work. But it is also formalized by the continuous affirmation of the researcher as the one closest to truth, an affirmation which is contained in the power of doing theory.

...the intellectual discovered that the masses no longer need him to gain knowledge: they know perfectly well, without illusion; they know far better than he and they are certainly capable of expressing themselves. But there exists a system of power which blocks, prohibits, and invalidates this...which subtly penetrates an entire social network. Intellectuals are themselves agents of this system of power -- the idea of their 
responsibility for "consciousness" and discourse forms part of the system....the forms of power that transform him into its object and instrument in the sphere of "knowledge". ${ }^{37}$

Systems of power which position the intellectual in this way, as theory-makers

independent of praxis make him a certain kind of agent. However, agency and self-

interest are never organized in a simple manner such that we could say whether this was

or was not in his best interests: "...the relationship between desire, power and interest are

more complex than we ordinarily think, and it is not necessarily those who exercise

power who have an interest in its execution...". ${ }^{38}$ The ruses of value-neutrality of theory

make aspects of power invisible to everyone. ${ }^{34}$ In the final chapter, my analysis of the

distributions of power that intellectual property protection promotes makes power visible.

This does not change these relations but it makes them visible to us.

3. Even scholarship which pays close attention to ways in which values are

inserted or perpetuated between the researcher and the subject-matter researched, and

Michel Foucault, "The Subject and Power." Afterword to Michel Foucault: Bevond Structuralism and Hermeneutics, $2^{\text {nd }}$ edition. Eds. Hubert Dreyfus and Paul Rabinow. Chicago: University of Chicago Press, 1983: 280-226.

38

Deleuze,Gilles, and Michel Foucault, "Intellectuals and Power." Language, counter-memory, practice. Ed. Donald F. Bouchard. Ithaca: Cornell University Press, 1977:215.

39

Unmasking the fact of positioning is not one and the same thing as identifying yet another single agent responsible for the positioning of the intellectual. That is a view of power that, in fact, sees the intellectual, ultimately, as a pawn and further displaces the question of accountability. The view of power that we will expand upon further on in this chapter sees the intellectual as embedded in relations, some of which are surely his own making. Identifying the locations of agency has as its primary goal precisely that: to make the nodes of power visible so that a critical awareness of, and practices of, agency can actually take hold, so that..."the intellectual [can start] to struggle against the forms of power that transform him into its object." (ibid:208). 
what those relative positions are, ${ }^{+0}$ may never acknowledge or reflect upon how its own modes of study, its modes of thinking, are also junctures to be examined. This involves the power inherent in doing theory, in making concepts, narratives and arguments. These are other less obvious politico-ethico zones of scholarship, of insertion and of resistance. It isn't necessarily the case that normative scholarship does a better job of reflecting on this aspect of itself. Examining the deeper conceptual presuppositions, not just the coherence of arguments that are built from them, could be called "critical ontology". If "research", "concept-building", or "theory" strike us as less important political activities this is not necessarily due to the fact that these have less impact on distributions of power. It is likely because theoretical concepts have been naturalized, over a particular intellectual history, as "common sense". Among the kinds of things that "common sense" take as patently true are that: "things" are more real than "ideas or theories", people more important than things," "physical acts" more causally efficacious than "beliefs", and "people" more dangerous than "concepts". The somnabulic effect of the presupposition that the bases of descriptive theory are common sense is a pervasive (and erroneous) sense of clear-conscience among academicians who, because of this, are comfortably

See the work of Joyce A. Ladner, Tomorrow's Tomorrow: The Black Woman. Garden City, N.J.:Doubleday, 1972.

41

Mauss suggests that the Western, secular belief that a person is the site of power, and the causal origin driving transactions, not the thing that they give (a thing becomes valuable or potent because of the will/emotion/motive of the person giving it, a contract becomes binding because of the mutual wills creating it), is the belief that prevented Western anthropologists from understanding "gift-giving" in non-Western societies as an unusual but nonetheless, basic form of contract. "Unusual" in that here it is the thing which is the primary site of power, the causal root of transactions, creating the roles of exchange around it. "What...compels the gift that has been received to be obligatorily reciprocated? What power resides in the object given that causes its recipient to pay it back?" (1990:3). 
apolitical about individual things, acts or people. ${ }^{12}$ Another kind of "unacceptable silence on crucial matters" then, is the kind when scholars perceive themselves to be and/or or are perceived to be, politically neutral with respect to their subject matter as regards their theoretical framework. This misperception cuts two ways: it diminishes the force of accountability so that scholars can continue to claim exemption from it, and, it augments the gradient against those who see and do theoretical work (as opposed to praxis) as political. Michel Foucault, one who falls into the latter group, comments:

..the idea that to devote oneself as we are doing now to properly theoretical and speculative activities is to turn away from politics strikes me as completely false. It's not because we are turning away from politics that we are occupied with such strictly and meticulously defined theoretical problems, but rather because we realize that every form of political action can only be articulated in the strictest way with a rigorous theoretical reflection.(emphasis added) ${ }^{33}$

Effecting redistributions of power is a possibility embedded in all analysis. In this way, doing analysis can amount to one and the same thing as effecting "political change", as being political. The genealogist, by putting into the mix an alternate account of property, can help to bring about change. Anthropologies of property are descriptive accounts of the operant distributive, stabilizing and de-stabilizing practices of power; how these appear as variable practices of property and ownership. And they are themselves prescriptive shunts within many actual and potential relationships ("self-enclosing

Gilles Deleuze. Negotiations. Trans. Martin Joughin. New York: Columbia University Press, 1995.

Michel Foucault, "Foucault Responds to Sartre." Trans. John Johnston. in Foucault Live. New York: Semiotext(e), 1996:55. 
designs"+1), within an already existing matrix of power such that studies can effect a redistribution within that matrix, more or less in alignment with any informing value: simplicity, utility or orderliness. Michel De Certeau claims that "writing both mirrors and incarnates a sense of historical order." ${ }^{\text {ss }}$

For instance, consider the concept of "history". What is obscured if a historiographer is not required to reflect upon and give an account of her theory of history? Conventional usage of the term "history", much of its conceptual furniture (like "periodicity"46), and conventional practices of historiography, tend to work as if "history"had an essential and simple rather than perpetually-assumed and complex nature. "History" itself is a concept. To paraphrase Foucault, it is a kind of thought, containing other kinds of thought ${ }^{\mathrm{y}}$ which creates the very possibility, and directs that possibility, of noting variances; i.e. for doing histories and anthropologies of property.

How effectively does classic historiography build-in the potential for critical analysis of its own underlying tenets about history? Longitudinal studies of variance are generally not unpacked for the ways in which it is the product of, an extension of,

Michel de Certeau, The Writing of History. Trans. Tom Conley. New York: Columbia University Press, 1988:x;32.

45

(ibid: $x v i)$.

46

Joan Kelly-Gadol, 'The Social Relation of the Sexes: Methodological Implications of Women's History." in Harding (1987:16-18). For the way periodicity affects Macpherson's reading of the development of property, see Reeve (1986:51).

47

Foucault, "The Order of Things" in (1996:18). 
underlying ontological presuppositions and commitments. ${ }^{+8}$

Important presuppositions include: the belief in origin or founding moments which are the key to the entire historical series; the belief that history unfolds, and this unfolding is natural; the belief that history lies under the surface of events and bodies, rather than is that surface (hence history as latency, as digging up what the body or the event "contains" ${ }^{14}$ ); the belief that history is a continuous, smooth, linear progression rather than discrete clusters and asymmetrical saltatory events; the belief that time is a unidirectional series with regular periodicity; the notion that cause acts like a unidirectional vector; the aesthetic and cognitive preference for laws or law-like determinations over unlawful determinants (homogeneous over than heterogenous domain); the reading of signs (verbal and otherwise) as the deposited, the already-there rather than the "included", the "excluded" and the made; the belief in a telos or progression in the movement of history (typically an incremental betterment ${ }^{\text {so }}$ ); the positioning of human consciousness as the motor of history, the central causal pivot for

See Franz Boas' discussion of the limitations of the methods of anthropology and ethnology, (especially deduction of causal links between parallel series), and the roots of these in the interpretation of parallel histories as sequential. Race, Language, Culture. New York: Macmillan, 1940:191-195;243-311.

49

For instance, the search for the soul of the criminal behind the act, and then in the body of the criminal to locate the history (origin and trajectory) of a crime. Michel Foucault, Discipline and Punish: The Birth of the Prison. Trans. Alan Sheridan. Vintage: New York, 1979:16-24;29-30.

so

David Schmidtz, "The Institution of Property." Social Philosophy and Policy 11:2 (1994):42-62. Schmidtz discusses how, having posited the State of Nature as valueless, and property-creation as beneficial (using the economic measurements of "efficiency" and "public good"), property-production from the past through the present appears only as a positive-sum game. 
each and every phenomena; and the positing of its corollaries --meaning and intention-as the central interpretive pivot for explaining each and every phenomenon.st

My point here is not to prove or disprove that time is unidirectional. Nor to make a case for how 'cause' actually works. My point is to suggest that any one of these ontological presuppositions has a profound impact on the way that a study of property is carried out let alone the "results" of such a study. It is thus to suggest that considering how these concepts work themselves out as histories needs to be included as part of one's study. Let's examine one of these.

Consider the conception of origin. This is a key idea which appears again and again in debates about property, both tangible and intangible forms. Nietzsche suggests that this idea is connected to the Christian belief in original perfection preceding human history, the Fall. The search for an originary moment, of thought or of work, to ground a claim to property is "a metaphysical extension which arises from the belief that things are most precious and essential at the moment of birth." s2

The "original acquisition" premise in private-property justificatory arguments lies at the root of most arguments justifying the ownership of land on the North American

This list has been gathered from: Michel Foucault, "The Discourse of History.":"History, Discourse, Discontinuity." The Final Foucault. Eds. James Bernauer and D. Rasmussen. 1994: 19-50; "Nietzsche, Genealogy, History." The Foucault Reader. Ed. Paul Rabinow. New York: Pantheon, 1984: 76-100; Gilles Deleuze, The Logic of Sense. Trans. Constantin V. Boundas. New York: Columbia University Press, 1990; especially series \#1; \#2; \#6; \#10; \#16; Appendix I, "The Simulacrum and Ancient Philosophy."

52

Frederich Nietzsche, "The Wanderer and his Shadow: \#3" Human, All too Human. Trans. R. J. Hollingdale. Cambridge: Cambridge University Press, 1986:302. 
continent since 1800 . The concept of "original acquisition" is parasitic upon the conception that there is a "State of Nature" which precedes the inauguration of the sociocultural, like property; the idea that history is strictly linear; and, also upon a particular set of signs for discovering the location of an origin. Whether or not we believe in an original behest, or in the version of time with an origin and a linearly-related now, or even in the hermeneutical integrity of the first white settlers (and subsequent jurists) with which they claimed that the land in North America was unoccupied (i.e. that their arrival was a moment of origin), those very conceptions have benefitted us insofar as they laid the foundations for the real property that some of us now "own".

This is because even though the thinking about private property defended by Filmer lost footing to what appeared to be an entirely different set of (Lockean) arguments, the concepts of origin (and of linear history progressing from this) was retained as an ontological commitment, by both sides. They differed in their accounts of where that origin lay and who had received or produced it. Since Lockean property arguments broaden the set of original acquirers to "the set of all possible first users of land", it seems as though his property framework should have been wide enough to include First Nations as owners. However, as James Tully has argued, ${ }^{33}$ even that modified framework operating in the Americas did not accommodate (conceptually and actually) Aboriginal peoples as property claimants. This is true for two reasons.

James Tully, "Aboriginal Property and Western Theory: Recovering a Middle Ground." Social Philosophy and Policy 11:2 (Summer 1994):153-180. 
First, because many Aboriginal groups have different conceptions of origin and time which make it difficult to understand their views about creation and property, and thus to be able to adequately "accommodate" their claims. This is also true across present cultures, and between Paleolithic and more recent Neolithic Aboriginals.

...virtually all the evidence indicates that Paleolithic people had no conception of time (or history) analogous to our own. Time was for them cyclical, and past, present and future were indistinguishable..st

A different history of time helps to explain why Christians rather than First Nations conceived of themselves as recipients of the of act of Creation, and why First Nations did not necessarily "challenge" that narrative.ss

Second, given that affirming originary moments requires a set of signifiers it is quite possible that the signs of Aboriginal presence and (therefore) landholding authority were simply not recognized, actually or legally, by the newcomers, as original acquistion. An excellent example of this comes from the British expansion into New Zealand. By the end of the $17^{\text {th }}$ century, in the British Empire, British landholders enclosed their holdings to help ensure exclusive use. "Enclosure kept the grazing animals of others away and also

Max Oelschlaeger. The Idea of Wilderness. New Haven: Yale University Press, 1991; Eliade Mircea. The Sacred and the Profane: The Nature of Religion. New York: Harcourt Brace Jovanovitch, 1959; Lynn White Jr., "The Historical Roots of Our Ecologic Crisis." Science (March 10, 1967): 1203-7; James Shiel. Greek Thought and the Rise of Christianity. New York: Barnes and Noble, 1968; Charles M. Sherover, The Human Experience of Time: The Development of its Philosophic Meaning. New York: New York University Press, 1995; Gerard Reed, "A Native American Environmental Ethic: A Homily on Black Elk." Religion and Environmental Crisis, Ed. Eugene Hargrove; Franz Boas, "The Idea of a Future Life among Primitive Tribes." (1940:596-607). On circular vs. linear conceptions of time, and the conceptions of debt, time and gift which follow, see Mauss (1990).

55

R. L Meek. Social Science and the Ignoble Savage. Cambridge: Cambridge University Press, 1976; Donald W. Large, "This Land is Whose Land?" Wisconsin Law Review (1973):1039-1083. 
provided a sign of the landholder's presence and authority." 96 The British convention of fence building was the chief sign verifying the efforts of acquisition, therefore of the status of land as owned. A lack of fences in the British Commonwealth, in Canada and in New Zealand, was taken as a sign of a lack of prior ownership. After Locke and Jefferson, ploughed fields, farm buildings and other "improvements" were added as marks of occupancy. ${ }^{57}$ To be sure, there already existed signs of prior, if not original, use: shell middens, worn footpaths, encampments, and even cultivated areas. But the Europeans could not or did not recognize these as valid or true historical records, given their particular conception of origin and its material indicators. ${ }^{58}$

This second example highlights the link between a conceptual dimension of property as it functions within historiography, the significance of this dimension to lived reality, and the importance of making the conceptual dimension explicit as part of one's study of these realities.

There is one last point of discussion regarding the limitations of standard descriptive scholarship. It has to do with thinking.

We have already noted that documentation-based research tends to (implicitly) conceive of the subjectivity of the researcher in three ways: as separate from what is

Eric Pawson, "The Land in Cultural Context. Two New Zealands: Maori and European." Inventing Places: Studies in Cultural Geography. Eds. Fay Gale and Kay Anderson. Cheshire: Halsted Press, $1992: 17$.

57 1989:64.

Eugene Hargrove. Foundations of Environmental Ethics. Englewood Cliffs, N.J.: Prentice-Hall,

58

Elspeth Young, “Hunter-Gatherer Concepts of Land and its Ownership in remote Australia and North America." in Anderson and Gale (1992:256-272). 
researched or discovered, as value-neutral with respect to findings, as free and independent with respect to concepts and patterns of thinking used to come to understand the objects of study. Chalienging these three assumptions suggests an even more complex conception of the researching self than value-inflector. It suggests that the actuality of a certain subjectivity (here, the researcher) depends upon, or is worked out through the actualization of thought.

Since thinking about thinking can be made a part of one's study then new thinking is a potential product of study as well. Where thinking is included as an object of study, there is potential for generating a new set of thoughts about a subject like property, not just what the thoughts "are about". This is not an automatic result of research activity. But if and when they are "worked on", these new, enlightened thoughts, are no less politically efficacious than the "concrete results" of study, since they effectively alter the researching subject as such. I will use a discussion of this same topic by Foucault to help elaborate my claim.

\section{Foucault on Kant on Enlightenment}

In "What is Enlightenment?", ${ }^{\text {s4 }}$ Michel Foucault explicates Immanuel Kant's (1784) answer to this same question. Kant's reply, according to Foucault, begins with an indictment of the common understanding of history, and how that understanding [re]creates a certain role for us. That role, according to Foucault, is an unenlightened one, 
no matter whether or not one is situated in a so-called "enlightened" era. In contrast, Foucault sees Kant's role, in his reply to this question, as marking, both in its form and its content, a novel entrance into the history of thought. It also sketches a novel role for the scholar in thinking in truly novel ways.

Foucault believes that Kant's entrance inaugurates a novel conception of the present and the Self's relation to it which has largely gone unappreciated and unpracticed in history and philosophy. Echoing Bourdieu, Foucault bemoans that it certainly has not disrupted the dominant practices of historiography. Foucault claims that Kant rejects "Enlightenment" as a collection of sociocultural markers like high art, rationalism, and legal rights. He suggests, rather that enlightenment (Aufklärung) is an ontological event, where thought is distinct from, but having relations to a past and a future. On Foucault's reading, Kant's response introduces and models a novel conception of the specific event with respect to its past and future which is a radically different conception of the present. Further, Foucault's claim is that this novel present is a better mode of thinking in the sense of being more productive, and hence more deserving of the title (thinking) than other activities which tend to be called "thinking".

Now the way Kant poses the question of Aufklärung is entirely different: it is neither a world era to which one belongs, nor an event whose signs are perceived, nor the dawning of an accomplishment. Kant defines aufklärung in an almost entirely negative way, as an Ausgang, an "exit", a "way out"...[h]e is not seeking to understand the present on the basis of a totality...[h]e is looking for a difference: What difference does today 1968.

\footnotetext{
Martin Heidegger. What is Called Thinking? Trans. J. Glenn Gray. New York: Harper and Row,
} 
introduce with respect to yesterday?

Given that we have both the will and the ability to exercise creative reasoning,

"enlightened thinking" is both a style and an historical moment in thought, an attitude of "breaking from". The results of this are a reconfiguration of the thinker and the thought (the researcher and the perceptions/conceptions regarding the object of study), a "modification of the preexisting relation linking will, authority and the use of that reason".62

Foucault has in mind here locales and formal relations of authority. The authority generally granted to the one who spoke before to whom one defers is a species of the more general authority granted to priority itself such as the authority that "origin" and discoverers of origin, garner. ${ }^{63} \mathrm{He}$ highlights the acquiescence with which today behaves toward yesterday. Foucault claims that there is a dominant and pernicious tendency to refuse to exercise independent reason and to appropriate others' (prior) reasoning, conceptual schemes, value presuppositions, as our own. Non-enlightenment is,

A state of will...that makes us accept someone else's authority to lead us in areas where the use of our own reason is called for.t

(ibid:34).

62

Foucault (1984c:34).

63

For a critical look at the authority of origin in scientific discovery, see Evelyn Fox Keller, Reflections of Gender and Science. New Haven, Conn.: Yale University Press, 1984.

64

Foucault (1984c:34). 
Every moment of investigation, however, offers possibility for thinking; that is, the opportunity to actually think rather than to merely reproduce. ${ }^{\text {ss }}$ For Foucault, since one's purported objective regarding the subject matter is not to reproduce, faithfully, exactly what has come before, then that objective can and should also be directed toward critical stance on all the underlying conceptual "givens" which are carried forward in one's thinking. We should investigate how it is that we have even come to have a presumed relationship of inquiry. As Foucault reads it, it was Kant's radical reconceptualization of the present which created a space for him to reflect upon his own positioning within a momentum-filled progression called 'the truth', through this reflection that his thinking became "a new object for knowledge or practice".. This is a different kind of thinking than that which produces the thinker as the (continuous) subject for knowledge or practice. An orthodox conception of history privileges the human subject $--u s$, the researcher and researched -- in the way it creates a "need to pass through the subject, through man as subject, in order to analyze the history of knowledge". .7

Cf. Gilles Deleuze, "The Image of Thought." Difference and Repetition. Trans. Paul Patton. New York: Columbia University Press, 1994a: 129-167. "It cannot be regarded as fact that thinking is the natural exercise of a faculty...'Everybody' knows very well that in fact men think rarely, and more often under the impulse of shock than in the excitement of a taste for thinking."(132).

66

Foucault, "The Discourse of History." ( $1996: 29)$.

67

Foucault, (1996:59) emphasis added. Is there a history which would not privilege a self-reflexive knowing subject? This depends upon the conception, or the perspective from which history is conceived as history. There might be other beings besides Homo sapien for which history is an important feature of experience, yet who do not "register" the way that "man" does as "history's subject". Another way of seeing what is at issue here is offered in a view like Heidegger's, where the relations between history, time and being are arranged such that human subjectivity is not the pivot of history: "....what our heritage of being has in store for us is the disappearance of man - of animal rationale, of subjectivity. (The Collected Works of Martin Heidegger. Frankfurt am Main: 
The suggestion about thinking, on the other hand, shifts and expands the realm of responsibility. "At the very moment of analysis each individual is responsible...for the overall process".as Thinking about his thinking, as he was "producing it" moderated the reproduction of the limits of reproduction - of "dogmatic, orthodox or moral image" on his own being. As a critical exercise, it clarified and developed a (potential yet rarely exercised) capacity within the wider, general capacity for understanding that knowledge-making activities see themselves as producing.

No doubt it was not the first time that a philosopher has given his reasons for undertaking his work at a particular moment. But it seems to me that it is the first time that a philosopher has connected in this way, closely and from the inside, the significance of his work with respect to knowledge, a reflection on history, and a particular analysis of the specific moment at which he is writing and because of which he is writing. ${ }^{n}$

Whether one is a thinker when one conceives of oneself as is positioned as a thinker, whether one can develop a real taste for thinking about one's thinking, what those new thoughts could be, and whether one lists these among the "findings", are some of the ways descriptive scholarship can be more or less politically, materially and philosophically robust.

Klosterman, 1976: v. 69:30).

68 Foucault (1984c:38).

69 Deleuze (1994a:131). 70 Foucault (1984c:38). 


\section{Summary of Descriptive Method as Evaluative Scheme for Property}

Studying property from the disciplines of economics, sociology, anthropology and history offers the opportunity to work with, rather than against, the variation exhibited in the ideas and arrangements of property. Because of this, it lends itself to a researcher understanding himself as a "situated knower". Classically, however, that role is seen as value-neutral. Further, disciplines which use a "scientific approach" to assessing property tend not to generate critical reflection on some of the other ways in which research can be politically laden, and by extension, more politically accountable. These might involve: the desire to connect with how one's discipline impacts the world it describes; the ability to ask how a discipline understands itself "as" history or "as" description; assessing methodological bias and conceptual commitments; and finally, analyzing the relations between the production of knowledge and the perpetuation of a set of effects, including a subject (researcher), who tends to "discover" his or her subject matter through the extension of prior thoughts and expectations. To the extent that sociologies, histories or anthropologies of property take on any of these challenges, they increase their ability to meet the challenge posed by the subject matter, property. Critical ontology is the tool by which descriptive method can be extended.

\section{Normative Analyses: Ethics and Politics of Property}

Alternatively, we could approach the subject of property primarily as a matter for normative analysis. Normative analysis in general seeks to describe situations and social movements in terms of the forces behind these, to critique or defend the legitimacy of these forces, or to critique or defend the kinds of ends that these forces achieve. Examples 
of normative scholarship include: feminism, marxism, and liberalism. Normative analysis of property entails demarcating a cultural or historical unit of property practices and arguing for their legitimacy or illegitimacy according to evaluative principles drawn from politics, moral philosophy or more recently, economics. Ethical or political theory often comparatives actual property domains, cross-culturally or cross-temporally ${ }^{71}$ as a way of illustrating the illegitimacy or desirability of one form over another. The variance in actual domains of property, then, are important to ethical and political analysis in at least this important respect.

\section{Strengths of Normative Analysis}

There are two main strengths to normative methodology. First, since we have claimed that property is significant to material and social well-being, working from a perspective which sets itself the goal to articulate which, among the available variants, are better or worse (and to provide arguments for why that is the case) is at least trying to be responsive to this aspect of the subject. Second, having evaluation as an explicit goal means that the researcher and the users of the research, are aware that there are values framing the work. From the outset, normative analysis does not start from the pretext of neutrality; rather, it forefronts the value dimension. This is its second strength. These two invert the shortcomings of descriptive work

\section{Shortcomings of Normative Analysis; How Critical Ontology Compensates}

71

This sometimes involves imagining a future trajectory of some form of property or some set of property-related behaviors. On the property-related aspects of childbearing and motherhood in a future of expanded use of reproductive technologies, see: Gena Corea et al., eds. Man-Made Woman. London: Hutchinson, 1985; Rita Arditti et al., eds. Test-Tube Women. London: Pandora Press, 1984. 
It seems necessary to give our due attention to the ethical and political dimensions of property.

However, we learned that a second feature of property is its variance, its multiple brute facticity. There is no good reason to take its variance to be a priori a less significant feature of property than we take its ethico-political dimensions. Yet, when we attempt to give these equal treatment, we arrive at a difficulty. Interestingly, this turns out to be not only a difficulty for doing normative analysis of property, but for classic normative analysis in general. Two kinds of reservations present themselves.

The first reservation concerns the general treatment of variance and plurality under normative directives. There are three different ways by which the plural is reduced. Each of these three ways is discussed. The second kind of reservation I have about normative projects is similar to one made about descriptive analysis: There are many ways in which normative theory, too, is capable of installing values above and beyond the ones it claims ownership of: in its hermeneutical practices; in the values carried forward by the parameters of the discipline itself; and in the configuration of its own particular authoritative subjectivity. A corollary question is: To what degree is normative theory capable of critically reflecting on this installation of value? As I claimed was the case with descriptive methodology, a lack of critical reflection in these areas increases the likelihood that normative work will be conservative; that is, will curb the growth of novel kinds of thinking, or new directions which thought might be taken on property. Further, a lack of critical reflection can perpetuate undesirables (whatever those might turn out to be) at the same time that it appears to be condemning them. This view of the dynamics of 
normative theory is not generally available from its own vantage point, but can be seen from critical ontology. It isn't in the best interests of a researcher, having chosen to work within an evaluative framework because of a commitment to some sort of goal, combined with an expectation that that framework can actually foster that goal in some measure, to have a partial, mistaken view of the relations between her scholarship and those possible outcomes. In Chapters Two and Three, a micro-politics of property will reveal this wider view of relations, allowing me, in Chapters Four and Five to map values to outcomes.

\section{Normativity and Plurality}

Material plurality has a paradoxical relation to normative projects. On the one hand, having multiple options is among the conditions for the exercise of ethical and political choice. There must exist a moral agent with genuine agency -- one whose ratiocinations or willful actions in the world are substantively distinct from the workings of necessity. The majority of debate in ethical theory, from Plato onwards, has concentrated on this necessary condition. But a genuine choice of emotions, logical pathways, intentional states, or states of affairs must be present to the moral agent. And, these must continue to be present, as an on-going condition for the ethical and the political, in three different ways: as that which initially presents an option and motivates concern and intervention; as that among which he or she can exercise choice; and as that which promises to be amenable to and to display another arrangement as a result of intervention. Variance is an on-going condition for ethical and political projects.

On the other hand, consider that the ethical enterprise itself privileges the critical over the variable. That ethics is a methodology for ranking among options suggests at the 
same time a ranking of the normative over the descriptive. Ethical projects understand their objective to be not merely rearranging variance but ranking it. Ranking variance is often a means to reducing variance.

Perhaps haunted by the spectre of ethical relativism, or, charged with being haunted by this spectre, ${ }^{2}$ an unconscious aim of normative analysis may be to unify and prioritize a One, thereby reducing the Many. This sort of treatment Foucault characterises as "the two-fold law of subdivision and lack." ${ }^{73}$ While this treatment may or may not always be seen within a normative system, such as utilitarianism or feminism, it is often seen between them. It certainly is true across examples of one kind of phenomenon. In the case of normative work on property, the aim is to promote one domain of property or one set of concepts grounding a certain system -- over the available others.

Does normative analysis, no matter how minute or grand an instance of it -- an opinion voiced, a paper presented, a Manifesto -- not function out of the premise that its exercise in the world not only ought to, but can, and does, reduce this variation towards a ranked set of realities, however circumscribed? This could be said equally of any of the key figures in normative property theory - Marx, Locke, Rousseau, Nozick, Macpherson

By this observation I want to suggest that contemporary ethical projects are, as a matter of fact, on the defensive against the charge that there is no position from which one could write a comprehensive theory of the good which is not in some way or another merely an articulation of local custom, i.e. describes or prescribes a nonuniversal good whose goal or relevance is already highly circumscribed.

73

Michel Foucault, preface to Gilles Deleuze and Felix Guattari, Anti-Oedipus: Capitalism and Schizophrenia. Trans. Robert Hurley, Mark Seem and Helen R. Lane. Minneapolis: University of Minnesota Press, 1983b: xiii. 
-- regardless of the goals of their particular visions.

The paradox is this: multiplicity is an on-going condition for the possibility of normativity, yet sustaining multiplicity is generally not the purported on-going goal of most theories of normativity. ${ }^{74}$

If normative analysis (toward an ideal) were sustained side by side with non-converging real, property practices, then we have the following possibilities:

1) normative analysis can not and does not actually have, or lead to, impact on states of affairs, (a premise about causal efficacy which drives the choice to pursue normative over descriptive work in the first place); or, 2) normative analysis can and actually does have a different, more complex kind of impact on states of affairs than that of promoting the One over the Many; or 3) multiplicity is an unarticulated deep goal of any normative analysis, and this has been accomplished alongside articulated others; or, 4) there are as many competing normative analyses, which do produce changes in states of affairs, but because of the multiplicity of ethical and political principles behind these analyses, these states affairs are precisely the non-convergent real property practices; or 5) normative work is itself built from a complex set of ontological presuppositions, which permits it to both use and override variance.

I cannot adequately reply to the first speculation or to the fourth. There is no position I could obtain that would allow me to trace and to confirm, with certainty, the causal chains between theorizing about a better world, and the changes that that

There are exceptions to this in moral philosophy. W.D. Ross's "prima facie" moral duties, and feminist standpoint theory are two examples. 
eventually makes or doesn't make, in that world. That would be as true of a single system, as of multi-dimensional input and its alleged converging or non-converging output.

I will make two small points, though, in the spirit of those two speculations. First, that it is somewhat of an article of faith rather than any sort of demonstrable proof that normative theory says something true, ${ }^{75}$ or can be said to be a causal root of effects upon what it theorizes. Yet this assumption is pivotal. But, second: to ask for a physical upshot or a logical demonstration as proof of the worth of thinking is to privilege outcome as the hallmark of, or the locus of the effectively political or the truly ethical. That we tend to look toward these connections might be little more than a species of philosophical prejudice. Thinking itself, not even thinking differently, is not necessarily a locus removed from ethical action, but could just as well be considered a "locus for potential transformations"76 mental, material or otherwise.

If we allow that "changes in thinking" can be one of the "goals" or one of the "impacts" of an ethical project, a reply to the second and third speculations is suggested.

This leaves us to discuss the fifth speculation, that the ideals of ethical analysis are convergence-inclined, and continue to be so alongside actual non-convergence, because built into normative arguments are a number of methodological and conceptual

John Stuart Mill. Utilitarianism. reprinted in Ethics: History. Theory and Contemporarv Issues. Eds. Steven Cahn and Peter Markie. Oxford: Oxford University Press, 1998: 345-346.

76

Aden Evans, et al., "Another Always Thinks in Me." Deleuze and Guattari: New Mappings in Politics, Philosophy, and Culture. Eds. Eleanor Kaufman and Kevin Jon Heller. Minneapolis: University of Minnesota Press, 1998:280. 
presuppositions which "override" and "off-set" variance. I believe that this actually is the case. If this is so, then the following discussion will also help understand how the fact of variance of property is deprioritized by virtue of some of the methodological practices built into normative disciplines. These practices neutralize the original challenge: How best to study this thing called property?

1. The first way that normative theory neutralizes multiplicity is through the use of abstract terms. ${ }^{n}$ Ethically and politically significant distinctions are subsumed under the (assumed) ahistorical, generic: "personhood", "rights", "State", "reasonable", "productive", "property", "harm", "theft", as in the following statements:

Institutions of common property impose costs of coordination and may dull the incentives for production and trade that a system of private property nurtures. ${ }^{\mathrm{x}}$

Getting money is a superficial reason for transferring a body part, at least when the seller has morally unproblematic ways of earning a decent living ...selling a body part might be morally objectionable if the strength of the reason for selling is insufficient in relation to the nature of the part sold."

A cross-disciplinary review by Reeve ${ }^{80}$ of these terms, as employed in normative analyses of property, confirms both this widespread use and this imprecision. This suggests that

I am not claiming that this is unique to normative theory, only that it is common to it.

Richard A. Epstein, "On the Optimal Mix of Private and Common Property." Social Philosophy and Policy $11: 2$ (1994):22.

79

Stephen R. Munzer, "An Uneasy Case against Property Rights in Body Parts." Social Philosophy and Policy $11: 2$ (1994):270-27I.

80

Reeve (1986:9-37). 
normative analysis works largely on the assumption that the abstract will do justice to the varied concrete; that there will be some kind an adequate relation (representational, mimetic, homologous) between things, actions, words and concepts. Whether and how the material could be represented by the abstract, and what the possibilities for relations between concrete and universal, are not questions which I am prepared to fullly explore here. I am pointing to these debates to suggest that a simple, straightforward conceptual adequacy ought not to be assumed. Wherever possible, the fact that this is a working assumption should be made explicit, and explored for the ways in which the universal or the abstract, which intends to subsume the multiple specific, may or may not be doing that, at the level of the actual. To assume that plurality of property is adequately broached by the conceptual schema we are working with, has the potential to mask precisely those areas which evaluative work should be scrutinizing.

2. A second way that normative theory uses and yet contains multiplicity involves the reduction of variance under binary categories: right/wrong, good/evil, reasonable/mad, Self/Other, oppressor/oppressed. This installs the normative itself as necessarily dual rather than multiple. Insofar as this not only overrides multiplicity, but installs a hierarchical scheme of positioning allowing (only) affirmation or denunciation, this binarization itself can be a kind of violence:

To install the term as that which can be only affirmed or negated is to force it to occupy one position within a binary, and so to affirm a logic of non-contradiction over and against some more generative scheme. ${ }^{x t}$ 
Frederic Jameson goes so far as to suggest,

...ethical binaries ....are always noxious and need to be eradicated by another mode of thinking ("beyond good and evil"). [This]...does not mean, as the fainthearted or bourgeois liberals believe, that morals in general are to be done away with and henceforth everything is permitted, but rather that the very idea of the Other -always transmitted through concepts of good and evil -- is to be done away with." ${ }^{\mathrm{sz}}$

What Jameson is suggesting is that the apparent "responsibility" of classic ethico-political analysis in general, and of value binaries in particular (therefore their preference), are themselves the effects of their own longstanding advantageous placement in a binary which makes all non-binary ethical projects Other, or inferior. Consider this dynamic in some feminists' rejection of postmodernism as an inadequate normative framework for responding to gender oppression. ${ }^{83}$ Nancy Hartsock, a Marxist feminist, first recants this politics of Other as dangerous for women, "the Other is always a Not, a lack, a void, as lacking in the valued qualities of the society...".". She wants a feminist theory that can undermine the positioning of woman as Other. However, rather than noticing that this is precisely what is being offered by postmodern political theory in its challenge to the ontology of presence and absence (in the theory of power offered by Foucault, in the theory of textuality offered by Derrida, in the theory of desire offered by Deleuze and

Frederic Jameson, "Marxism and Dualism." A Deleuzian Century? Special Edition of The South Atlantic Quarterly 96:3 (Summer 1997):412 emphasis added.

83

Sandra Lee Bartky, "The Making and Unmaking of a Feminine Self." paper delivered at the Atlantic Region Philosopher's Association Conference October 13 ${ }^{\text {th }}, 2000$, King's College, Halifax, Canada.

84

Nancy Hartsock, "Foucault on Power: A Theory for Women?" Feminism/Postmodernism. Ed. Linda J. Nicholson. New York: Routledge, 1990:160. 
Guattari), the collapse of binaries which follow from these postmodern challenges, and hence the release from the tyranny of Other, she chastises Foucault for not dealing adequately with the "binary opposition between ruler and ruled". Hartsock, and others, demand that binary oppositions be fore fronted. But what Butler and Jameson are suggesting is that this methodological requirement reproduces the oppressing architecture of the Other/Self. A more fundamental oppression, then, is retained, at the heart of projects whose express intent is to overcome it at sociocultural levels. Foucault claims that this criticism can be made of any binarizing politic, no matter what the ideological structure these are meant to be hung on. ${ }^{\text {s }}$

Deleuze suggests that when "we are shown innumerable points of confrontation, focuses of instability...instead of analogy, homology or univocality, we have [to create] a new kind of possible continuity." " This "new possibility" would require that we generate evaluative criteria from within workings of a discursive field, bearing in mind "the perplexity of real historians", ${ }^{87}$ rather than impose "thick-skinned" ${ }^{\mathrm{xx}}$ binaries upon it. In my second chapter, using a microphysics of power, I describe the general workings of the field of property. In Chapter Three, I use this account of power to do a specific genealogy

Michel Foucault, "Two Lectures." Power/Knowledge: Selected Interviews and Other Writings, $1972-$ 1977. Ed. Colin Gordon. New York: Pantheon, 1980: 78-108.

86

Deleuze (1988a:25).

87

(ibid:21).

88

Deleuze and Guattari (1987:138). 
of property - "a study of the forces that produce the particular symptoms" instance, the particular symptoms of the public/private split, and intellectual property itself. Then, using this, in Chapter Five, I explicate and use a non-binary evaluative scheme - cartographic analysis -- to assess intellectual property.

The second way, then, that normative scholarship, on the surface, moves toward "a uniform regime" 90 while making use of diversity (here, positing and positioning it) in order to create, and endorse that apparent surface movement, is through the use of binary terms.

3. The third way that many normative projects reduce variance has to do with the kinds of ontological commitments held. Certain ontological assumptions allow us to "read" historical and cross-cultural variance as a condition calling for normative analysis, as requiring remedial political and ethical intervention. These drive a second assumption that variance is the effect of some species of privation or lack. Those lacks might include: a lack of progress, a lack of properly open communicative practices, a lack of power, a lack of technological know-how, a lack of critical-thinking capacities, a lack of exposure to the truth, a lack of tolerance, a lack of phallus, a lack of wealth. Each would require remedy. "Scarcity" or "oppression" are seen as the pathological results of having deviated from a base standard, considered to plenitude or presence. In property, that is the state of

Philip Goodchild. Deleuze and Guattari: An Introduction to the Politics of Desire. London:Sage,

"This preference for one uniform regime for natural resources is not confined to the uncompromising champions of private property....the socialist tradition, starting with Marx and Engels in The Communist Manifesto called strongly for the abolition of all private property rights in land..." (Epstein (1994:19)). 
nature where "the fruits belonged to all and the earth to no one".91 Deleuze and Guattari

claim that Marxism, as well, assumes this ontology. They write,

...a Marxist philosophy cannot allow itself to introduce the notion of scarcity as its initial premise: "Such a scarcity antedating exploitation makes of the law of supply and demand a reality that will remain forever independent, since it is situated at a primordial level. Hence it is no longer a question of including or deducing this law within Marxism, since it is immediately evident at a prior stage, at a level from which Marxism itself derives....2

Variance, then, is often understood as a secondary phenomenon, as a deviation. If this is the presumed ontology of any undesirable state, then this dictates that the proper reply is to remedy the privation by mobilizing a positivity. This positivity would be a principle or a method which reduces the multiple. ${ }^{y 3}$ Like the conception of history we looked at before, this particular ontological presumption authorizes a certain kind of moral theorist and a certain kind of moral agent. It authorizes the vocation of normative intervention, the installation of the authority which remedies the privation by ranking among the available options.

This ranking creates a hierarchy, which states of affairs must move through, on their way to a higher unity. Typically, the highest unity reflects some attribute of the authority (such as rationality) who adjudicated among the options in the first place. This

Jean-Jacques Rousseau, "Discourse on the Origins and the Foundations of Inequality among Men [1755]." The First and Second Discourses. Ed. Roger D. Masters. New York: St. Martin's Press. $1964: 141-142$. 92 1970: 330 .

Deleuze and Guattari, (1983b:28fn) quoting Maurice Clavel. Qui est aliene? Paris: Flammarion.

93 109.

Michel Foucault. The Archeology of Knowledge. Trans. A. M. Sheridan. New York: Pantheon, 1972: 
creates a positive feedback loop between the perception of the kinds of reconfiguration in states of affairs which is necessary, and the perception that there are specific persons capable of effecting it. This authority which installs ranking, tends to not recognize itself nor criticize itself in the operation of normative assessment."

\section{Normativity and the Manifold Installation of Value}

The first area of concern I had with normative methodology had to do with the treatment of plurality. I have just suggested that there is a link between this treatment, the installation of values or authority, and also the invisibility of this installation. In this section, I will pursue the questions: to what degree is classic normative theory capable of installing values other than the ones it explicitly claims to be working toward? To what degree is it capable of critically reflecting on this installation of value? To what extent does it actually do that? As was the case with descriptive analysis here, too, a lack of critical reflection on these increases the likelihood that normative work will be dangerous or simply conservative.

I would like to make two final points about the insertion of value into normative theory, and say something briefly about the conceptual frameworks which make these largely invisible. I would like to suggest how these biases constitute shortcomings for the discipline, and how critical ontology is needed to offset these. The first involves the view

Butler (1995:35-57) makes this point specifically with regard to the way in which the oft-heard declaration that politics cannot proceed without a "subject" (politics, meaning the critical interrogation of ruses of authority and oppression) -- i.e. that postmodern philosophy is not property political or politically-useful -- is itself a gesture of questionable power. 
that ethical and political philosophy is metaphysically neutral, and that it ought to be. The second involves the privilege that only certain institutions (Church, State or University) enjoy as sites of knowledge and sites of intervention within and for the normative project. This is certainly true of the project of critiquing intellectual property. While this bias serves contemporary "moral authorities" well, it may not actually engage with the complex range of forces which produce and propagate social and political problems; that is, it may not serve the issue well.

First bias: The view that normative analysis is free of metaphysical "trappings".

Ontological riddles are not the typical riddles which normative theory entertains. In fact, these kinds of questions are sometimes overtly declared either to be moot, to fall outside the scope of political philosophy, or worse, to obscure the clarity of the real issues. A case in point is demonstrated in the title of John Rawls' article: "Justice as Fairness: Political, Not Metaphysical". ${ }^{9 s}$ Sibyl Schwartenbach echoes this assumption:

Rawls' conception of the person is indeed a "political" one and makes no specific metaphysical claims in regard to the nature of persons or personal identity beyond this." 4

To oppose the "political" to the "metaphysical", as if these were independent categories of reality (rather than nominally independent categories within the discipline of philosophy), is false. One could not function in any kind of capacity without making

John Rawls, "Justice as Fairness: Political Not Metaphysical." Philosophy and Public Affairs 14 (1985):223-251.

Sibyl Schwartzenbach, "Rawls and Ownership: The Forgotten Category of Reproductive Labour." Canadian Journal of Philosophy 13 (1995): 141. 
metaphysical claims, or relying on a set of ontological presuppositions. This is equally true whether one is working in classical critical framework, or in a postmodern framework. Certainly, Rawls's social contract device (the "Original Position") does not need to assume universalities about the nature of "human" intention or deep "human" character (for instance, that all humans are fundamentally selfish, or that all humans are fundamentally social) in order to function effectively as an heuristic for the distribution of primary and secondary goods. However, he does assume (and needs to assume for the device to function) a number of other truths about the kinds of things that reality, not just "political reality", is made up of, and how these fit together. These include: some conception of personhood (that this is an individual more than a universal, an integrated, rather than a dispersed thing, and primarily soul, then body); some conception of causality and power (that people can and do want things and pursue certain means to effect these); some conception of the social (that a median-driven socius is better than a limit-driven socius); and some conception of temporality (even if he uses "origin" and "projection" as abstract devices). It is true that the goal of political philosophy may not be to solve metaphysical puzzles such as the nature of time, or whether a person is composed of body, soul or some combination of these. To set these to the side seems perfectly reasonable.

However, the express goal of normative projects should not be to "minimize obfuscating matters like ontology"but to be clear about which specific metaphysical claims one is taking for one's "givens". For example, a dominant metaphysical given which is taken, consistently, across all kinds of ethical and political work, and which 
makes a vast difference in that work, is the assumption that a human being is made up of two parts, an outer body and an inner soul (or mind), and that the latter is the most essential part of the human being. This claim, which is being made whether explicity stated or not, has a corollary in the inattention often paid to concrete material realities of one's subject matter against the extensive indulgence regarding the state of the mind, or the soul of (for instance) the patient, the criminal, the voter, the rapist. To be silent on these matters, to pretend that they play no part in one's work, veils one's choices, especially to oneself. Where these choices make a big difference to ones political projects (as we showed is exactly the case with the base assumption of presence), it is at some level in one's own interest to explore these ontological biases, because they might offer an entirely different angle on the very work that one is committed to.

Michel Foucault's Discipline and Punish is the kind of study which does exactly this in the area of penal reform. His methodology combines the descriptive and the evaluative. It inquires after the ontological presuppositions which support practice. Foucault focuses our attention on the ontological assumptions driving events in modern penal reform, specifically, how the production of "the soul" of the criminal, as the chief object of juridical intervention (judgement, salvation, reparation, extraction of debt) is carried out through the infliction of surface brutalities on the body of the criminal, under the auspices of the need to extract or to reprimand that deeper reality,

....the body is...directly involved in a political field; power relations have an immediate hold upon it; they invest it, mark it, train it, torture it, force 
it to carry out tasks, to perform ceremonies, to emit signs.97

The soul of the criminal is saved via what Foucault calls elsewhere a bodily "process of destruction". 9x

Whether there is a soul even to be saved is entirely hypothetical. But, this primary hypothesis, this ontological commitment is masked because the body, in all of its possible reactions to destruction, cannot help but to affirm the postulate of soul. It is this positing, rather than any independent fact of the matter, which allows the body to affirm the fact called the soul. This has also been said about the human body as a kind of postulate, rather than a given. ${ }^{9}$

A very similar case can be made about the moral principles which frame modern normative projects. Take the principle of autonomy. The realignment of power that Locke argued for, into chains of private (democratized) property, was the promise to extend the possibilities for genuine human autonomy; that is, make man an actor in his own life rather than a pawn within a larger, wholly determined lifeworld. Morally or politically sound projects continue to be identified by the degree to which they foreground this principle. Yet we can approach this principle not as a given, but as something

Michel Foucault. Discipline and Punish: The Birth of the Prison. Trans. Alan Sheridan. New York: Vintage, 1979:25.

98

Foucault (1984c:82-83).

99 (1987:149-168).

Butler (1993); see also Deleuze and Guattari, "How to Make Yourself a Body-Without-Organs." 
foregrounded through the mechanics of ontological commitment and the proofs available in its enactment. Genealogical analysis doesn't have, as its aim, to do away with autonomy but rather to understand its importance as an historical and cultural factor undergirding and extending moral and political projects. Judith Butler, in her genealogy of autonomy, reads the dynamics involved with the entering into, administration of, media coverage of, and actual combat tactics of the Gulf War. That war, allegedly a fight for human freedom, Butler reads as having been highly successful not in terms of a measurable increase in autonomy for Kuwaitis, but in terms of having created a space, a theater, for the successful performance of the principle of autonomy, per se. She writes of smart bombs and opticai relay, that they "secure a fantasy of transcendence...of sanitized agency in the world." ${ }^{100}$ The human subject as autonomous being is reconstituted, while

...this constitution is concealed by the effect of autonomy. In this sense, autonomy is the logical consequence of a disavowed dependency, which is to say that the autonomous subject can maintain the illusion of its autonomy insofar as it covers over the break out of which it is constituted. ${ }^{101}$

Genealogy shows us that what is "given" can be said to be an interaction between one's ontological commitments and how those are affirmed or disconfirmed in one's interpretations. It is to suggest that there is a kind of deeper and very significant, generative relation (where what I am calling "values" are inserted), which precedes even the facts of the matter. An adequate normative theory must have a framework complex

Butler (1995:44).

101

(ibid:46) emphasis added. 
enough to be able to notice these generative relations. In order to do this, it needs a comprehensive theory of forces. In Chapter Two, I show how that theory of forces is available in a microphysics of power. In Chapter Five, I adapt this further to include the formal features of these forces, features which I believe offer a framework for seeing and assessing these deeper, generative relations between ontology and the reality that is being assessed.

Second bias: Privileging institutions of knowledge as truth-bearers and sites of intervention.

The last point I would like to make regarding the junctures where dangerous, conservation or simply self-serving values are inserted into normative projects involves the way in which particular sites are privileged, culturally, as loci of transformation. At this point in history, it is the institutions of higher, formal education - the University which occupy this loci. That this is so is the result of a particular history of "truth" which has promoted rationality over non-linear, non-expedient thinking, formal codifications of knowing over informal ones, written over oral statements, men over women, and the intellectual over the corporeal (including the social body). This set of biases is significant to any study in two ways.

First, it obviously affirms the vocation of the intellectual without necessarily alerting him to the fact that this vocation is individuated as a generic subject position before he comes to occupy it. Intellectuals in this way help to propagate the myth of sui generis. As we will see in Chapter 4 , this myth is essential to the stability of a system of intellectual property. Relatedly, this placement decreases the likelihood that the moral 
expert, the ethicist, will reflect upon the function that her judgment plays in the wider politics of knowledge. It diverts attention away from other epistemic agents. In the domain of intellectual property, this can mean on the one hand, failing to credit an intellectual heritage adequately; on the other hand, restricting the scope of epistemic responsibility. The bias of location that academics enjoy fails to notice the broader dimensions of epistemic authority.

As a way of multiplying our attention away from a single foci such as a University, Foucault distinguishes between two kinds of domains in which the epistemic dimensions of a given subject-matter are built-up and circulated in a society. These are $l a$ connaissance and le savoir. ${ }^{102}$

By the term connaissance, Foucault is referring to what we might call "classical knowledge", the "bodies of learning that one can find in scientific books, philosophical treatises, mythological and religious edicts...the knowledge of institutions and their practices." 103 For any given society, we can investigate and discover the connaissances of property. For the most part, these will inhere in legal statutes and moral codes charged with identifying ownership or theft. The ethicist has authority here. This locale of authority, the "corset identitaire"104 [identifying corset] which an intellectual takes up,

Foucault (1996:13). For a careful distinction of connaissance from savoir including translation issues, see James Faubion's "Introduction" to The Essential Works of Michel Foucault: Volume Two. Ed. James Faubion. Trans. Robert Hurley et al. New York: The New Press, 1997:xiii-xliii.

103

(ibid:13-18).

104

Guattari, Félix, “1985: Microphysique des Pouvoirs et Micropolitique des Désirs.” 1980-1985: Les Annees d'Hiver. Paris: Barrault, 1986:213. 
isolates and desingularises ("s'appauvrir et s'affaiblir") rather than cultivates him as an individual. What is significant about this is that of the entire complex of values which an individual might bring to her critical assessment of the domain of property; those which reflect the position of the ethicist take priority when he speaks from that position. This almost ensures that ethico-political issuances remain simplistic and oppositional. ${ }^{105}$ In addition to connaissances, however, Foucault insists that we explore the distinct yet isomorphic domain of savoir. This refers to a wider, not-yet-entirely articulated or demarcated, yet implicit and configuring sub-soil of knowing. This sub-soil is no less vital and efficacious. It might include: everyday opinions, minor techniques of evasion or punishment, emerging unpopular ideas, commercial and police intents, fiction and non-fiction, local mores, mythologies, grammars and dialects, regional interpretive codes, temporary experts, tools, or meaning-giving spaces. This savoir conditions the possibilities for institutionalization of knowledge as connaissance. To unearth and understand the variance which exists at the conceptual level in a culture about something like property, we must, according to Foucault, study not only the general or dominant history of ideas on property, but "all that contains [such] thought...of all in which there is thought" 106 about property. This will include both les savoirs and les connaissances. Both

For an account of how the subject position "feminist", within an oppositional ethico-political framework diminishes one's license to form a judgment about abortion or to give a complex account of abortion to oneself, see Linda Bird Francke, "The Ambivalence of Abortion." The Gender Reader. Eds. Evelyn Ashton-Jones and Gary Olson. Toronto: Allyn and Bacon, 1985: 464:468; Naomi Wolf, "A Call for Truth." Contemporary Moral Issues, $2^{\text {nd }}$. Ed. Lawrence Hinman. Prentice-Hall, 2000:31.

106

$$
\text { Foucault (1996:18). }
$$


these bear upon the evaluation of property in that, together, they order, describe, challenge, endorse or justify certain forms, purposes, objects and administrative codes over others. They are as much a part of the normative fabric as ethicists and their principles, but they tend to be excluded by institutionally-focused normative projects. Part of the reason for this lies in the fact that the uptake of the identity of a "moral expert" increases the likelihood that she will be subject to what Guattari identifies as, "une profonde 'logophobie', une volonté farouche de maitrise...derrière la logophilie". ${ }^{107}$ This "logophobia" would decrease the likelihood that institutionally-located normative projects, even if they wanted to, might not be able to access these broader domains of knowledge, or enter it as an equal among equals. ${ }^{108}$

\section{Summary of Chapter One}

Working through the options of normative and descriptive scholarship, I have highlighted what I take to be the limits and the assets of each of these. For each limitation I have suggested ways in which these might be overcome or compensated for. The tools for doing this are available from a framework of critical ontology. Critical ontology improves upon classical normative or descriptive theory in that it does not ignore the past, the facts or the projects which follow; that is, the assets of each of these methodologies. Rather, it expands the boundaries of each of these by investigating the ontological

$$
\text { Guattari (1986: 213). }
$$

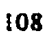

On the impossibility of "accessing information" through fieldwork, and how this is a direct function of academic location, see Jayati Lal, "Situating Locations: The Politics of Self, Identity and "Other" in Living and Writing the Text." Feminist Approaches to Theory and Methodology. Eds. Hesse-Biber, Gilmartin and Lydenberg, Oxford: Oxford University Press, 1999: 100-137. 
assumptions which support each of these as possibilities or as effects. Critical ontology is not just a critique of other methods: it is a distinct means for seeing a phenomenon. One of the "maps" that critical ontology uses to show us the dynamic interactions between conceptual possibility, facticity, description and evaluation which make up a field of research is a microphysics of power. Making this map almost guarantees that the one doing the analysis must reflect upon the role that she plays in her descriptions or her judgments, both as a kind of position of authority and as a kind of "holder" of ontological assumptions. Making explicit that the point of departure of investigation is our own actuality, requires me to have a greater degree of self-consciousness about the way in which my questions and answers are in the service of a complex of intentions, not independent of these. As an intellectual, writing about intellectual property, my framework must include (but not end with) an attempt to say how I am empowered or disempowered by a regime of property in ideas. Moreover, it must include reflection about how and why it is that at this point in history, the conditions are such that my thoughts are both subject and the object within a certain discursive field. This is a more complicated account of situatedness than merely identifying the location from which I am speaking. I have claimed that while critical ontology doesn't make analysis "value-free", it promises to make its range of values and its value-complexity more apparent. I have also claimed that incorporating this value-complexity enables us to replace one evaluative scheme with another.

In the next chapter, then, I begin to use the tools of critical ontology to "read" the domain of property. The chief tool is a microphysics of power. 


\section{Chapter Two: Power}

\section{Introduction to Chapter Two}

In the last chapter, having examined the limitations of traditional descriptive and normative approaches, I argued for the importance of an alternative critical framework which could compensate for these limitations by making apparent the ontological presuppositions which underlie either methodology. I also insisted that this alternative critical framework must be able to work with material and historical variance, and be able to work toward or generate evaluative principles. I claimed that critical ontology was this better framework. I also claimed that a microphysics of power was an excellent tool for making visible the complex of underlying "forces" which organize phenomena like property.

In this chapter, I examine property using a Foucauldian microphysics of power. Foucault did not treat property as a subject of study; however, it is amenable to Foucauldian analysis. One of my aims in this thesis is simply to show what a Foucauldian analysis of property would look like, since, to the best of my knowledge, this hasn't yet been done. I begin with an account of Foucault's notion of power, which helps us to identify the axes of force through which discursive fields are constructed and maintained. I claim that property is a discursive field, and hence can be analyzed in terms of these axes of force. This chapter concentrates on theories of power as a kind of constructive 
axis for a domain.'

One of the axes which are constitutive of a domain like property is theory.

Theories about property have a significant role in the production of concrete manifestations of the phenomenon itself. Two distinct and politically important theorists of property were those of Robert Filmer, a patriarchalist, and John Locke, a liberal reformer. The role that these theories played in the historical development of property is complex, both in relation to the actual forms of property which have arisen since Filmer and Locke, and also in relation to the way these theories themselves intersect. Critical ontology directs our comparative analysis of theory to a different level, to that of the ontological "mechanics" of power which underlie a theory. I make explicit the theories of power which underlie Filmer and Locke's positions on property. One of my specific aims in this chapter is to show that Foucault's theory of power improves upon ${ }^{2}$ these previous accounts of power in its complexity and thus in its explanatory capacity regarding how property, as a whole, works. ${ }^{3}$

The next chapter looks at specific conceptual terms (the binary of the public/private) in the construction of the domain of property. Chapter Four examines the roles of subjectivities. Chapter Five examines formal features of the domain.

2

There is nothing in micropolitics which asks that we choose between theories of power. Micropolitics augments and complexifies macro views of power. It also critiques some of the operational shortcomings of macro views of power. The first of Foucault's regimes of power - Juridico or Sovereign -- corresponds roughly to the liberal view of power. But Foucault identifies two more forms of power which are not historically bound (i.e. that liberal power has evolved from it or will evolve into it); they may coexist within any given historical moment.

3

In subsequent chapters, I will show that Foucault's theory of power also improves upon Locke's with respect to its evaluative capacities; therefore meeting both criteria for an adequate methodology. 
Interestingly enough, looking at these mechanics reveals commonalities and continuities where we might presume there to be none. However much Filmer stood for everything that the radical whigs like Locke protested against, at the ontological level, certain aspects of his position have been retained as part of the liberal position. Critical ontology shows how it is possible that liberalism is committed to a theory of power which sometimes works against the achievement of the goals it claims as its proper ends. Systems of property and ownership which developed after Filmer and Locke do not strictly exhibit or conserve the kinds and forms of power each of these theorists claimed to have been endorsing. Kinds and forms of property are generally understood to be manifestations of power. However, there is not a perfect isomorphism between the theory of power offered and the actual systems of property which existed or which came into existence, because (among other reasons) the kinds and forms of power described by Filmer and Locke did not exhaust the kinds and forms of power operating in, or rather as the regime of property. This is especially true where "property" itself is conceived as "thing-like" rather than as a kind of "relation". It is partly due to the fact that these deeper conceptual commitments of Filmer and Locke's theories are carried forward in new forms and conceptual modes of property that the variance identified in Chapter 1 is propagated.

My second intention in this chapter, then, is to make apparent that the notion of power as it presently appears in common parlance and property debate (as one of its features), is actually an amalgam of Filmerian and Lockean aspects. The view of power which liberalism draws upon -- that "common sense" Filmerian/Lockean amalgam -- is indispensible to the liberal project in the sense that it is a key power/knowledge node in 
the matrix of power that Foucault describes. A critical ontology reveals that that node simultaneously "produces a problem" and the opinion that liberalism (theory and practice) is the best position to reply to that problem. It is indispensible, then, not because it can actually lead to the securing of individual and social projects like equality and autonomy, but because, as a set of ontological commitments, it sustains and empowers the liberal position itself.

Showing the operation of power in property is of critical importance to our ability to understand, to make accurate assessments of the reasons behind the relative successes or the failures of various groups to become empowered through the kinds of ownership legitimated by the liberal framework, moral and political. ${ }^{4}$ Clearly, understanding these deeper continuities is of critical importance to our ability to make good recommendations for future strategies for overcoming disempowerment or achieving goals like equality or autonomy through present and future property practices. In the next chapter, I use a microphysics of power to try to understand two very different kinds of examples of this: one historical (the interactions of Aboriginals and European colonists), one experiential (the interactions of pregnancy with the public/private distinction).

In a similar vein, Catherine A. MacKinnon (Toward a Feminist Theory of the State. Cambridge, Mass.: Harvard University Press, 1989) outlines the complex relations between feminism, the liberal state and marxism as an alternative to the liberal paradigm. She urges women to be wary of the gap between what liberalism promises and what it delivers to women, specifically, in matters such as rape jurisprudence. My analysis of the deeper analogous forms of power which two apparently distinct positions on property draw upon help to explain this gap. My analysis here also vindicates Foucault warning that revolutionary politics which subsumes the principle of sovereignty cannot help but to extend rather than overcome domination. ( Power/Knowledge. Ed. Colin Gordon. Trans. Colin Gordon et al. New York: Pantheon, 1980b. see especially "Two Lectures": 105-108; "Truth and Power':121-122). 


\section{A Foucauldian Microphysics of Power: General Elements of Discursive Production}

Michel Foucault's intellectual project was to provide a methodology for understanding how the sociopolitical works, its tendencies, its processes. The total social field, in Foucault's view, is an on-going complex matrix, subject to a kind of general mechanics. Foucault called these "rules of discursive practice", 5 and their engine, 6 "power/knowledge". Within this total social field, Foucault does not privilege the knowledge of institutions and their practices as knowledge, but envisions power/knowledge as productive of all theoretical and practical forms of knowing, of connaissances and savoirs.

\section{Limits: Inside and Outside}

A chief effect of the general mechanics of power/knowledge is the production of boundaries or limits within that general field. These boundaries are neither solid nor permanent, nor do they inhere at one level, such as in the codified distinctions which make up "the Law". What is contained within a limit-set, and what is excluded from a limit-set at any given moment in time actualizes a "strata or an historical formation",? a particular phenomenon. Phenomena are roughly recognizable as areas of the social:

Michel Foucauit. The Archeology of Knowledge. Trans. A.M. Sheridan. New York: Harper Colophon, $1972: 216$.

6

See Colin Gordon's account of the positive function of power/knowledge (as engine rather than blockage) as Foucault's unique contribution to theories of power in the "Afterword" to Power/Knowledge (1980b:229-259).

7

Gilles Deleuze. Foucault. Trans. Sean Hand. Minneapolis: University of Minnesota Press, 1988:84. 
"property", "health", "education", "family". Specific features of the historical formations are the objects and statements which, "gather on that stratum". ${ }^{8}$ The combinations of what can be said and what can be seen -- "visibilities" and "sayabilities" - cohere as new zones of social regularities (like "racism"), while others diminish in heft and clarity (like "the Commonwealth").

\section{Normal and Abnormal}

What is excluded from a set (abnormalities and deviations, what cannot be said or brought into light) and what is included in a set (normalities and exemplars, what must be said and seen) are differentiated from one another, yet mutually dependent. We cannot know or work with the meaning of "normal" independent of demarcating the "abnormal". This is true of any pair: rational and irrational, efficient and wasteful, private and public, ownership and theft. These binarizations, which give form to all social phenomena, gain their momentum and general approbation by virtue of their alleged epistemic function: knowledge about "normal" and "abnormal" is gained through study; study warrants approbation by virtue of its ability to produce the distinctions of normal and abnormal. The ability to produce any kind of distinction, not simply what a distinction is about, is an expression of power. This localizes knowledge to certain places, persons and forms of expression. In the modern world, knowledge is Good. And thus knowledge functions with the kind of force that Sovereignty once used to. This is not a scientific-based sovereignty, however. Recall that for Foucault, "studies", "truths" and "knowledges" (or what can 
operates as these) are not restricted to scientific realms but flow through all levels of human thought. Two of Foucault's observations, that whether something falls into a zone of authority or outside it, changes constantly; and that "the normal" always have authority (voice, judgment, rights) over "the abnormal", led him to posit that power relations can be found wherever these so-called knowledge relations are being established. Foucault called these general movements, the combination of power/knowledge which organizes domains and phenomena: "discursive productions":

Now these groups of regularities [discursive practices] do not coincide with individual works. Even if they appear through them, even if they happen to become evident for the first time in one of them, they extend substantially beyond them and often unite a considerable number of previously unrelated phenomena. But they do not necessarily coincide either with what we habitually call sciences or disciplines, although their boundaries can sometimes provisionally be the same."

\section{Individuation}

This organization of units of regularity from a whole, and the expropriation of coherent units to general phenomena, is a general formal process of individuation and deindividuation. Individuation and deindividuation also happens at the level of the human, as internal to each of these domains, subject positions, characteristics, personae, become visible and productive as modalities of power: "intellectuals", "perverts", "authors", "mothers". Each of these subject positions will be regulated by the general categories of inclusion and exclusion, normality and abnormality. An "original thinker" is

Michel Foucault. Resumé des Cours: 1970-1982. Paris: Julliard, 1989:10. 
never found independent of a "copyist" or an "idea thief". ${ }^{10} \mathrm{~A}$ "mother" is never without a

"non-mother" whenever she appears in the social field. It is through the continual

appearance and inflection of the non-mother as non-mother that the mother can even be

named and seen." Foucault called these "subjectifications". Unlike the classic liberal view

of subjects and autonomy, Foucault denies that there can even be an independent subject

position, since one's position is always defined against another's; more precisely, that

one's position is constituted as a possibility by virtue of another's. ${ }^{12}$ Subject positions are

closer to what Foucault called "objects" than to "statements", although they have a

relation to statements as the subject of the statement. But, again challenging the liberal

view of "equality of opportunity", not everyone occupies, can occupy, can refuse, or can

10

1995: 37-50.

Félix Guattari, "I am an Idea-Thief." Chaosophy. Ed. Sylvère Lotringer. New York: Semiotext(e),

11

See Sarah Blaffer Hrdy. Mother Nature: A History of Mothers, Infants, and Natural Selection, New York: Pantheon, 2000. Hrdy discusses the concept of "mother-child bonding". This idea is an excellent instance of the modulation and extension of the personae human "non-mother" and "mother" from "scientific evidence" which does not, in fact, make the case strongly enough to explain the uptake of the concept (bonded or unbonded mothers) as a basic truth about mothering aptitude, and the ways in which this idea has modified mothering practices. Hrdy discusses the changes in post-partum practices on American obstetrics wards which come on the heels of this notion of adequate mothering as immediate bonding.

12

Here, on the role of the Other in ethics and epistemology, Foucault can be aligned with Emmanuel Levinas, Totality and Infinity: An Essay on Exteriority. Trans. Alphonso Lingis. Pittsburgh:Duquesne University Press, 1969; Jürgen Habermas, "A Theory of Communicative Competence." Recent Sociologv No.2. Ed. H.P.Dreitzel. New York: Macmillan, 1970; also Drucilla Cornell, "What is Ethical Feminism?" Feminist Contentions. New York: Routledge, 1995:75-106, and "Feminism, Negativity, Inter-subjectivity." (co-authored with Adam Thurschwell) in Feminism as Critique. Eds. Benhabib and Cornell. Minnesota: Polity Press, 1987; Allison Weir, Sacrificial Logics. New York: Routledge, 1996; on the role of the Other in formation of an individuated consciousness of self see Jessica Benjamin. The Bonds of Love. New York: Pantheon, 1988 (after G.W.F. Hegel, The Phenomenology of Spirit, B, IV, A: "Independence and Dependence of Self-Consciousness: Relations of Master and Servant." J.L.H. Thomas, trans. in Hegel: Selections. New York: Macmillan, 1989). 
even see these subject-positions let alone takes up enunciations and identities in relation to them. ${ }^{13}$

\section{Relations, dynamic}

Neither discursive formation nor subject formation is prior to the other, but these are linked in a circular relation of induction and extension: ${ }^{14}$ and these, transversally, across many potential fields and styles of synthesis. However, the field is prior to the effects; that is, there is a primacy of power over knowledge. ${ }^{\text {s }}$ The emergence of a series of effects is always local and specific; it is "not that anything can be linked up with anything else." ${ }^{16}$ Deleuze likens the sequence of events to a Markov chain, where "the probability of each state is dependent only on the event immediately preceding."17 Nothing is subject to an external rule of order, nor to an internal determination. What is true, however, of all "production, regulation, distribution, circulation and operation", of

Deleuze ( 1988a:63); see also Michel Foucault (Madness and Civilization: A History of Insanity in the Age of Reason. Trans. Richard Howard. New York: Vintage, 1988a) on the relative capacities of the poor, the criminal, the marginal, to resist the identity of "mentally ill" compared with those of physicians, psychiatrists and prison wardens.

14

Foucault, "Truth and Power."(1980:133).

15

Deleuze, (1988a:81-93).

16

(ibid:86).

17

(ibid:86). 
things and words, phenomena and personae, is that they are inextricably linked to the production of truth.

Foucault's chief tool for explaining the constitution of discourses and subjectivities was his microphysics of power. In Foucault's story, power is a technique which makes individual subjects.

There are two meanings of the word subject: subject to someone else by control and dependence, and tied to his own identity by a conscience or self-knowledge. Both meanings suggest a form of power which subjugates and makes subject to. ${ }^{18}$

These techniques are always intentional: ${ }^{19}$ that is, they comprise a vector, although it may or may not be "exercised" by an intending individual. An "intending individual" is one among many possible levels or sites of exercise of technique. Nor is subjugation always in the interests of an individual, although it can be.

Power

Foucault insists that we must not restrict our understanding or our notion of power to something which can be gained, stockpiled or lost. For Foucault, power is not a sort of thing with inherent utility, localizable and moved about in order to achieve ends external to it. To see or to look for power as a kind of thing someone has or is, is to confuse power with something like money. Money is indeed a thing (or a set of interchangeable lexified

Michel Foucault, "The Subject and Power." in Michel Foucault: Beyond Structuralism and Hermeneutics, $2^{\text {nd }}$ Edition. Eds. Hubert L. Dreyfus and Paul Rabinow. Chicago: University of Chicago Press, 1983:212.

19

Michel Foucault. The History of Sexuality, Volume One. New York: Vintage, 1980a:94. 
things) which can be acquired or lacking. Some people have a little, some have a lot. Or, they are identified as having in the sense of ready-at-hand or being able to access some supply. Yet the strength or perhaps even the power of money which makes it a thing which we are able to use the way(s) we can, lies not in that thingness. The shape of paper, the smoothness or sheen of shells, the density of metal are qualities of a thing by virtue of which relations can be established which implicate and use a thing as an index of convention. Even the attribute "rarity", such as the American Buffalo nickel has, is on the one hand, something about the thing (its number), but on the other hand, something about the relations it can enter: a calculable limitedness. None of these comments about money are new. Locke himself wrote that a treasured thing like gold -- "a little piece of yellow metal"zo - is really treasured insofar as it works, in a recognized form, through a circulating agreement. It would not and could not act with the wide, variable effectiveness it does if its operation was put into play by a unilateral decree. Or if it was created, ex nihilo, by a single individual, as in Locke's version. Or even if it was strictly limited to a two-way exchange. What is in agreement is that gold or money stands in for, symbolizes, takes up the space of, a value which can inhere in or pass through it. This is about coding. The agreement regarding codification need not be actual. The ability to inhere in, or pass through, is the effect of a very particular function of modern power -- a machinic function -- which might be expressed as an actual agreement among persons. 
Deleuze and Guattari, echoing Foucault, do not identify the liberal State as the single body responsible for organizing the functions of money, but rather as a "concrete arrangement that puts a society's overcoding machine into effect." 21 The system of money is a vast, tangible, infinitely codifiable system which supports an open set of not-strictly-material relations' of circulation. These relations include what are called "personal relations" between persons, moments, items of worth and immaterial equivalences; and what are called "public relations" which involve multiple would-be transactors. What also circulates is a common intention and the sustained will that certain items, things and persons will stand for public and private values. Finally, these relations of circulation are orchestrated by an "abstract machine",

...that organizes the dominant statements and the established order of a society...the segments that win out over others. The abstract overcoding machine assures the homogenization of different segments, their convertability and translatability; it rules the passages between them and establishes the conditions of passage...[F]or example, the different monetary segments and the different kinds of currency have rules of convertability, both within the system and externally with goods, which refer to a central bank as State apparatus. ${ }^{22}$

To notice that money or gold's force lies in a set of operant ties rather than in an independent density or nature, is to give a nod to Foucault's account of power. Power, if it is to be located at all, can be found in these relational ties: in a non-localizable

1983a:79. 
betweenness. The more betweenness, the more efficacy. Deleuze and Guattari reiterate this idea when they claim that "the middle" or "the plateau" is the zone of maximal intensity: "The middle is not at all average, far from it, but the area where things take on speed."23

"Power" is not something having independent Being which circulates between or across infrastructures of relations -- juridical, economic, sexual, affinal, parental or fraternal. Power is nothing more than these relations. In his writings, the words "power relations" have often replaced the single word, "power". That there are relations discoverable -- two or ten points of transfer -- is to discover influence or efficacy. Finding the power relations (two points, a consistently long line, a zone of identity where recognizable patterns occur), rather than analyzing who uses power and for what ends is how a Foucauldian analysis of power differs methodologically from others.

The idea of power as relational is not new, nor is it restricted to Foucauldian discourse. Frequently, "power relations" is used to describe what was once simply "power". Academia, for instance, is frequently described as "full of power relations".We might think that this semantic shift, which ties power to a context (the classroom) and to a set of subjectivities and human relations (the teacher, the student), indicates that the Foucauldian notion of power has entered the general conception. However, a closer look at how these "power relations" are understood, (such as how they are described as political obstacles, or as universally inhering in a kind of person ("White", "Professor"),

(ibid:58). 
the old idea of power as object-like, thing acquired and transferred, is revealed. What is meant then, by "power relationships" is a dyad made up of one person who "has" power and one who does not. These relationships are shaped like pyramids, ladders, or trees. On this model, nodes of affect and transfer are assumed to be only either superior or inferior. All other positions of affect and transfer are assumed to be derivative of these two. Each member below the apex has only one active neighbor. The positions are prior to what passes between them, therefore power is "acted out" rather than more freely "performed". Channels of transmission are pre-established therefore relations are "reproduced" rather than "traced". ${ }^{2+}$ In Foucault's model, by contrast, there is no submission of the lines and spaces to the point. ${ }^{25}$ An arborescent image ${ }^{20}$ of power relations tells us that there is a closed set of players and limited nodes of operation of power, already marked for relative worth. Foucault's model, on the other hand, suggests that the primacy of power operates more like a rhizome, opening up a series of propensities "to know transformation". ${ }^{27}$ Each of these descriptors suggests an aspect of a Foucauldian methodology.

\section{$\underline{\text { Resistance, transformation }}$}

24

(ibid:26).

25

26

27 (1997):413.

Deleuze and Guattari, “1730: Becoming-Intense, Becoming-Animal.” (1987:293).

Deleuze and Guattari, “Introduction: Rhizome."(1987:16-17).

Frederic Jameson, "Marxism and Dualism." A Deleuzian Century? The South Atlantic Ouarterly 96,3: 
Foucault writes that the possibilities for transformations are "already always everywhere", not merely in predetermined persons, histories or locales. Power is not created ex nihilo: power relations are extended and discovered as new linkages are recognized, imagined and forged. This connects with my earlier discussion of "Enlightenment". Imagination, creative thinking, turns out to be one of those sites where change can be made or change can be restricted: it is caught up in relations of power. To "get free of ourselves...think differently than one thinks, and perceive differently than one sees, is absolutely necessary if one is to go on looking or reflecting at all." ${ }^{2 x}$ Deleuze and Guattari claim that the arborescent, or tree-like model of power is, by virtue of its solidity and formal features, antithetical to creativity.

It is not easy to perceive things from the middle, neither from top to bottom or the reverse, nor from left to right or the reverse: try, and you will see that everything changes....29

\section{Ontology}

The ontological features of a Foucauldian microphysics of power are: 1) it is relational, not substantive: power is nothing other than the relations of things and persons, 2) power is exercised not held: it is not something which people and things possess or do not possess (naturally or by inheritance), and then enter into relations of exchange, 1990b:8. 
obligation, rights with, it is nothing other than the entire locus of exercise of possibility; 3) power is everywhere, which is to say that it comprises a fabric or a matrix which is the social reality, it is not located in specific places, like a ladder or a bank within a reality that only certain people or certain things have access to; 4) power is neither, strictly speaking, "natural" or "conventional", but it is brought forward. It can be made to support "natural" and "artificial" as categories; 5) no one and nothing is "exterior" to power, or independent of it, but can only change in degree of relation and intensity to other nodes within any given local region of power relations; 6) where there are relations of power, there are also the possibilities of resistance, which is to say that resistance is not a position opposed to, and removed from, a position of power, but a mode of possibility among the many which inhere in the power relation itself. This is true too, of the question of power's "legitimacy". ${ }^{30}$

\section{Property is a Discursive Regime}

As a phenomenon, "property" is multiple, not singular nor didactic. It is historical, not ahistorical; yet its history is not necessarily linear or progressive. Its formation is discursive,

...passing from one topic to another; ranging over a wide field; proceeding logically or coherently from topic to topic...not flaming into meaning but a steady commentary in the course of which the meaning is systematically conveyed....31 
Its domain is the social, and this domain is complex, not cleanly demarcated by the haves and the have nots. In all likelihood, property did not arrive to human culture once and for all: not ex-nihilo, nor in a Godly behest, nor in the turn of a spade, nor in one clean shift from savage (classless) to barbaric (early class) society ${ }^{32}$ nor in the 17 th century, nor even, strictly speaking, in any contract which agrees to it. "Property" is a discursive field which continues to be organized and propagated as a habitual set of sociocultural forms and their attendant effects. This habitual set is nothing other than the network of power-knowledge relations which have appeared as relatively stable effects of property-relations among individuals, families, nations and species. These stable effects happen with respect to property in the same general ways that all other discursive categories are formed and practiced; that is, through: 1) specific subject positions; 2) specific nodes of power/knowledge, or authority; 3 ) a given range of objects (material possessions, names, truths) which stand in for, and can display (perceptually, textually) relations as relations of property rather than relations of religion or health; 4) a set of dividing practices which individuate, and delimit visibilities and statements as internal to the domain, while excluding others as foreign to it; 5) a set of specific capacities or mechanisms to resist or to take up property relations with a larger set of relations which is the whole. "How people see it is both effect and cause of what it is any given time." ${ }^{33}$

32 Press, 1972.

33 Press, 1978:1.

Frederick Engels. The Origin of the Family, Private Property, and the State. New York: Pathfinder

C. B. Macpherson, ed. Property: Mainstream and Critical Positions. Toronto: University of Toronto 
"Property", like "sexuality" and like "madness", is constituted through:

...(1) the formation of sciences that refer to it, (2) the systems of power that regulate its practice, (3) the forms within which individuals are able, are obliged, to recognize themselves of subjects of this [property]. ${ }^{.4}$

Since discursive productions are never static, they continuously penetrate new areas of the social field, but not necessarly at regular intervals, with a steady tempo, or in one direction. Nor do they apply continuously across a given set, such as the set of all women, or the set of all patent holders. Since power is exercised rather than possessed, thus we could not say that all women have it or all women lack it: we could at best, assess who is able to exercise power relations within this discursive field. This relative capacity is the overall effect of strategic positions, which, regarding property as much as regarding sexuality or criminality, will be manifest itself in each instance as a specificity of mechanism and modality.

Power relations, permeating this discursive regime, appear largely in the form of the capacity to form and manifest the conditions recognized as ownership and non-ownership (theft). "Ownership" is a different kind of thing than "mere possession". C. B. Macpherson articulates this distinction. I will quote a series of his comments since they support my claim that property is a discursive formation:

In common usage, property is things; ...property is not things but rights, rights in or to things.... 
This holds both for products...held in common and for..individual property. In both cases, to have a property is to have a right in the sense of an enforceable claim to some use or benefit of something...

What distinguishes property from mere momentary possession is that property is a claim that will be enforced by society or state, by custom, convention or law. ${ }^{35}$

Macpherson does not wish to imply here that it is force which creates or justifies this right which is the right of property. His contention is that the will, ability or necessity to exclude or to include is invoked and supported as an instrument which guarantees a right which is more basic. That, for him, is the basic right of humankind to thriving, which requires security of persons and things, i.e. property. For Macpherson, this more basic right precedes and drives the legal and cultural relations which appear as property. A Foucauldian ontology of power does not discard the view of power which Macpherson (and others) build their account of property upon: it can subsume that account. It expands the account of the mechanics of power to include the force that is provided by the claim about human thriving, the force of approbation for property which derives from a certain account of what it means to be human. This force joins the other forces such as the acknowledged claims to property that a community can convey to a particular kind of individual. While we can see, as Macpherson does, how those relations between persons known as property relations have been concentrated in and as a habitual state of relations - private property, the State -- we can also see how these rely upon and support a much more intricate and vast matrix of relations which is the whole of the political. 
...property is a political relation between persons. That property is political is evident. The idea of an enforceable claim implies that there is some body to enforce it. The only body that is extensive enough to enforce it is a whole organized society itself or its specialized organization, the state. So property is a political phenomenon. ${ }^{36}$

Significantly, if we accept Macpherson's thesis that all property rights are rights (and therefore means) to exclude and include, then there is no essential difference between the two main forms of property - private and common - though it is often assumed that these are ontologically distinct. Rather, any differences between these are the results of different mechanisms of licence and authority regarding who may exclude what:

For any given system of property is a system of rights of each person in relation to other persons. This is the clearest in the case of modern private property, which is my right to exclude you from something, but it is equally true of any form of common property, which is the right of each individual not to be excluded from something. ${ }^{37}$

The important point for Macpherson is that common property does not consist in an absence of individual rights, but in a unique arrangement of these. Similarly, State property, from the point of view of its mechanics, resembles private property. The important point for my purposes is that to say that property is a political phenomenon, in view of Foucault's theory of power, is to say that it is the net force of property's discursive relations which qualify property as one type or another, disqualify claims, tolerate illegalities, distribute licenses, and institute social controls between persons

(ibid:4). 
regarding use, alienability, transfer or access. This suggests that no one is entirely powerful or powerless. Since we are all embedded in multiple relations of power which have as their object or aim, "property", we cannot declare ourselves to be once and for all "for" or "against", say, private property. To investigate property means to investigate theoretical and practical aspects associated with the phenomena of "property" as they appear across fields of knowledge, types of normativity, and forms of subjectivity, and this will always include the normativities and subjectivities which we depend upon to give us the formal position from which we speak on the matter. There is a linkage between the theories of property enunciated in the $17^{\text {th }}$ and $18^{\text {th }}$ centuries, and the production of a position to speak about these, and to evaluate these, from. That linkage can be uncovered by examining the ontological frameworks of those early theories of property.

\section{Filmer and Locke on Power, and the Creation of Property.}

That private property has, since the $17^{\text {th }}$ century, dominated the political and moral landscape of the West as the right and good form of property, that it has become identified with a set of things, relations and locales, should not confirm that private property is indeed the truer and higher form of property relations. This trend confirms that between the late $16^{\text {th }}$ century and today, identifiable changes took place in the power substrate which sustained a distinction between Public and Private; which facilitated the massive expansion of the Private, and its enforcement. This would have happened as different sciences referred to it (economic, political and moral), different systems of power regulated its practice, and different forms emerged within which individuals were 
able, and were obliged, to recognize themselves as subjects of either private or public property.

A major contribution to these effects was made via the theories of property developed by Filmer and Locke. Locke was "the first to make a case for property of unlimited amount as a natural rights of the individual, prior to governments and overriding them." Locke's conception of property, and the effects which followed from it (including the two identified above), is a consequence of his theory of power. Its novelty was to suggest that power itself is thing-like, and limited only by the extent to which any given individual exercises his or her capacity to make power and property. A particular set of ontological assumptions of power and of property inserted by Locke have ensured that the domain of property itself since Locke is characterized by a particular kind of ontological "commitment". In what follows, I will examine in detail these theories of property, and point out the ontological assumptions contained in them.

\section{Filmer's Theory of Property}

John Locke's (1690) Two Treatises of Government is a direct reply to Robert Filmer's (1680) Patriarcha: The Natural Power of Kings. ${ }^{38}$ Filmer's account defends the continuation of the feudal land tenure and transfer practices of aristocratic holding and entail, primogeniture, and royal endowment. Rights of ownership in land were enjoyed exclusively by Kings, the sons of Kings, and whoever Kings looked well upon. For Filmer, this pattern of real property rights was true and good because it was, according to

Robert Filmer. Patriarcha and Other Political Works. Ed. Peter Laslett. Oxford: Blackweii, 1949. 
many, the earthly manifestation of the only true system of power: the power which mankind had received as an original endowment, from the "Fountain of all Power",39 God himself. For Filmer, "power" is not something which we humans have by nature, or can generate independently, according to our individual needs and purposes.

More specifically though, Adam had received the gift of dominion from God, and hence only Adam's sons -- the eventual Sovereigns of the four kingdoms of the world -could receive and transmit power, this "indivisible beam of majesty". There is a normative relation between Filmer's ontology of power and the distribution of that power in the world. The ideal pattern of ownership and governance should exactly reproduce the hierarchical lineage of sovereign power: in the political realm, as the absolute rule of Kings over subjects; in the private realm, as a total rule of fathers over their dependents; and in general, as the rule of men over women. ${ }^{+0}$ The ontological features of Filmer's conception of power are: 1) it is substantive (thing-like: acquired, held, and transferred); 2) it is specific: that only some can be bearers of it, and only temporarily; i.e. that it exists as a social hierarchy and as a unidirectional vector; 3 ) it has an origin and source outside of the human dimension; it is used and transferred by humans but not created by them; 4) it and the rights associated with it, are natural, not conventional;"1 and 5) its legitimacy is

Locke (2nd Treatise Chapter I:4).

40 This, since Eve (women) who was created after Adam, \& from him.

41 Some would argue that the relations of power, between God and God's sons, was indeed conventional: a covenant with his chosen ones. The original insertion of God's power into the line of humans perhaps can be 
determined by blood right or fiat, ${ }^{42}$ not by how it is exercised or to what ends it is applied.

Since, from Filmer's perspective, all men were not equal, unequal distributions of power appeared natural. The real patterns of ownership and governance in 17 th-century England, in public and private reaims, did, in fact, match this sovereign, patriarchal pattern; Filmer's account appeared to many to be truest because of this "fit". To argue against this system, then, Locke needed more than just general political appeal. He would have to ground his theory of ownership in a theory of power which would challenge and supplant Filmer's story of social forces. This theory of power would have to articulate and support the long term democratic ideals of a Lockean theory of property -- "the humane kind where Man and Man is united into a fellowship of equals". ${ }^{+3}$ Thus, his challenge would have to have two structural parts: it would need to supply a different account of the source of power in order to back the picture of individual human autonomy his challenge focused on, and it would need to show as convincing a fit between his story of power and the actual distributions of power which existed or were beginning to develop. ${ }^{+4}$

understood as a kind of convention. Here, the contracting parties are by no means equal or requiring co-operative reciprocity, thus we are closer to a Hobbesian conception of contract than a Lockean one.

42

Similarly, some would argue that the legitimacy is a matter of the original fiat of God entrusting Adam with the dominion of the Earth. However, as with the origin in convention, all subsequent transfers of power occur through blood right (nature) rather than by fiat or convention.

43

Locke (2nd Treatise, Ch.XV:10-15).

44

This is exactly the point that Filmer challenged Locke on, saying something like: "clearly your story that everyone, by nature is free is absurd! look at those children there, look at those slaves!" Parents do have power 
Locke posited not one, but three different kinds of power: Political, Paternal and

Despotic. Only the first of these two he considered legitimate for subjugation and rule; that is, only "political" and "paternal" were acceptable forms of power in a civil society. Locke claimed they were necessary for it. Property relations emerge between members of the political.

\section{Locke's Notion of Despotic power}

Despotic power, according to Locke, is the illegitimate form of absolute power of one Man over another, seized through tyranny, conquest, usurpation. The continuation of arbitrary power of one Man over another, over time, is also despotic no matter how long it has been "since" original usurpation. By "arbitrary", Locke was referring to the accidental nature of the means select individuals had to their advantage, and through which they could exercise or inherit power. These accidents would include strength, family or favor. Despotic power comes not from some essential true human nature (contra Hobbes), but from "having quitted common reason". Locke's basis for rejecting despotic power as unnatural lay in his fundamental premise that all Men are equals, and that as equals, they have a natural and non-arbitrary power in their own being, and cannot arbitrarily surrender this, even under violencess or in piety. Nor can they exert that part of

over their children, and it is not "contracted", but neither is it "illegitimate". Locke's concept of "paternal power", of the natural powerlessness of children to their parents until the age of maturity, is Locke's reply.

45

Locke makes an exception for slaves "taken in just war", which, he claims, must be reinstated in their natural state of self-rule when the "despot enters into Conditions with his Captive". 
their being which is unequal (arbitrary) to take advantage over others. Legitimate governance among humankind cannot arise from illegitimate (accidental, non-universal) means.

\section{Locke's notion of Paternal Power}

"Paternal power" is, in Locke's system, the legitimate, non-absolute, non-arbitrary and natural form of power, of governance, that parents have over their children, while the children are in a state of "nonage". In otherwords, they are governed by paternal power until they come to the age of Reason when they can then enter into relations of Political power as free and equal adults. There were two intentions behind Locke's conceptualization of paternal power: First, because it was obvious to anyone that children were in no way equal to their parents, nor were they free: they were certainly embedded in relations of rule and obligation, in relations of power. The obligations and rights of parents clearly could not have derived from any sort of Compact with their offspring. But Locke had thus-far only identified contracted governance as legitimate, to distinguish it from the illegitimate forms of political power like Despotism and Monarchism. Thus, by positing this second form of power, Locke ensured that there would be a good fit between his overall theory of power and the different, actual forms of governance and rule that existed (in this case, those of the private realm). Yet, he could speak about these private realm relations in terms which made these independent of Bible or King. Thus, this conception of power saved him from having to call parental power over their children illegitimate, or to posit private relations as substantively similar to political, public ones. 
Thus, with "parental power" Locke was able to complete a broad picture of power while distinguishing the private from the public realm on a substantive basis. This distinction was essential for the liberal departure from patriarchalism, which actually had not made a sharp distinction of public from private and thus was able to continue to draw upon kin and affective ties to legitimate political arrangements. The public/private distinction was less cleanly distinguishable before Locke. Locke substantiated these as distinct through this novel conception of power, and this distinction is now such an essential feature of liberalism $^{46}$ (in particular regarding matters of the Family vs. the State), that it appears natural rather than what it is: an historically-bound political conception.

The second reason that Locke posited "Parental power" as a form of power (and not, say, of natural affection) came, I believe, from Locke's intuition that delimiting the private as private served public political goals well, but would not necessarily serve the interests of those who occupied the private realm (primarily landless wives, slaves and children). Locke's second intention seems to have been to delimit the arbitrary and despotic nature of the paternal familias in the private realm: to indicate that here were relations not exactly political rights (which he reserved as the feature of the civic realm) but certainly of mutual support and obligation.

The ontological features of paternal power are: 1) it is relational: established

One of the earliest and strongest arguments made on behalf of Liberalism against the intervention of the State into private matters can be found in J.S. Mill's On Liberty. Ed. Currin V. Shields. New York: Liberal Arts Press, 1956. 
between a dependent child and her parents, ${ }^{-7}$ however, that relationship is not equal; 2) it is thing-like, or substantive, only to the extent that the parents "have" it; have the right to wield it, over their child at a time when the child "has" none, and then, that the children, in turn "have" an obligation to reciprocate the same "Help, and Preservation" to their parents when the parents have "dispensed" with theirs entirely; 3) it is natural, not conventional; 4) it has its origin in the human dimension, in the creation of a dependency, a child; 5) it is specific: a specific individual can exercise it, and a specific charge is subject to it, and this, only temporarily, and 6) its legitimacy is founded not only by age and blood, but in a committment to the care of the dependent. ${ }^{\text {th }}$ It is important to note how, in key respects, Locke's conception of paternal power preserves some of the structure and intention of Filmer's "patriarchal power". ${ }^{49}$

Some might say that Filmerian power is relational, between God and his chosen sons. But a child born a king receives that power from his father (he has it, he inherits it). We don't know whether God is party to this, symbolically or actually.

48

Locke does put some qualifiers on the terms of its exercise, for instance, saying that it is not within a parent's right to exercise threat of Life over a child, nor to dispense with a child's property as a parent sees fit. (Book Two, Ch.VI:65).

49

Hargrove makes a supporting comment, too, that at least under Sovereign power the King had obligations to his subjects (positive duties), and could be held accountable for them, two links which could be said to form at least a minimal fabric of social welfare between them. He points out that under democratic power, it is much more difficult to pin any responsibility on anyone (Hargrove is writing from an environmentalist perspective), and aiso, that the rights associated with individualized power are chiefly of negative and positive liberty, and include very few positive obligations for intervention (Foundations of Environmental Ethics. Englewood Cliffs, New Jersey: Prentice-Hall, 1989:62). 


\section{Locke's version of Political Power}

I turn now to Locke's conception of "Political Power". This notion represents Locke's most important break with Patriarchalism. It is considered to be the inaugural moment for liberalism since it is this version of power which is used to build and to justify the unique modern institution, the democratic state. This conception of power is derived from Locke's primary premises: that all of Mankind in a State of Nature enjoy a State of perfect freedom and of perfect equality. Locke's view of what makes us human is an optimistic one: that we are all governed by Reason, and,

Reason, which is that Law of Nature, teaches all Mankind, who will but consult it, that being all equal and independent, no one ought to harm another in his Life, Health, Liberty or Possessions. ${ }^{50}$

According to Locke, we have a natural ownership in our own being, in our bodies and minds: no one else, by nature, is our subordinate or superior. We also have a duty to preserve what is ours, by nature. This includes the preservation of body and of the Earth, which, Locke argues, is the gift from God to all. When we think of what "preservation", as a demand, means today, it is usually a matter of keeping something as close to its natural (unused) state as possible. It is a conservative directive. However, the duty to "preserve" articulated by Locke had an entirely different meaning. Locke asserted that "the State of Nature" both is inefficient" and has no intrinsic value. In the same way that

Locke (Book Two: Chapter II:6)

See Pete Daniels, "Technology and Ethics in Agriculture." Journal of Agricultural and Environmental Ethics (1993):52-59 on the conversion of the impetus for production and efficiency from persons to machines. See also Amory Lovins, Hunter Lovins and Marty Bender, "Energy and Agriculture." Meeting the Expectations of the Land. Eds. Jackson, Berry and Coleman. Berkeley: North Point Press, 1984:68-86 on expanding our understanding 
property is created, value, too, is created by human beings in the act of engaging with Nature and changing it, refining it, making it into something productive. He declared that, ...Land that is left wholly to Nature, that hath no improvement of Pasturage, Tillage or Planting, is called, as indeed it is, waste and we shall find the benefit of it amount to little more than nothing. ${ }^{.2}$

If our productive engagement always only increases net value, and increases efficiencies, then there is a moral and an economic obligation toward productivity: we are obliged to make use of what we have, for the betterment of all. Both Lockean Provisos ("as much and as good" and "only as much as you can take without spoilage"), which seem to suggest Locke had in mind cautious and responsible use of resources, can be gotten around by economic arguments which show that there is more economic value in use than in non-use or limited use. Another argument put forward is that "scarcity" can always be overcome by market mechanisms for distribution and increasing efficiency ${ }^{53}$ Generally then, Locke's underlying ontology of Nature and of value, does not support a conservative directive. Indeed, it is considered the mark of the wise, the reasonable and the civic minded to use rather than to conserve. The contemporary sense of the directive

of "efficiency" from economic to biological, and what different this makes to environmental policy recommendation.

52

Locke (Book II, Chapter V:42).

53

Jan Narveson, "Resources and Environmental Policy." unpublished paper presented at Ontario Philosophical Society Annual Meeting, Ottawa, Ontario, 1991. 
for "preservation" would count as disvalue: inefficiency, deliberate waste or spoilage..$^{s+}$

Now Locke, like Plato before him, ${ }^{55}$ wanted to argue for the legitimacy of some form of government and not for a complete lack of it, for a State of Nature or Anarchy. But any form of government involves the subjugation of one man to another, even if now to all one's brothers rather than one's King. And any form of government involve rules and mechanisms for their administration, which constrain the natural license of humankind and builds relative inequalities into the social field. Locke, therefore, needs to have an account of power which can explain how such bonds of control are made between individuals, why they are made, and why they are legitimate.

Briefly, according to Locke, men freely consent to civil society because as a civil society, as a single "Body Politik". they enjoy a greater security of person and property, and a greater range of personal possibilities than they would have enjoyed independent of a civic union. Political power is nothing other than these forged bonds. Locke claimed that no one is made worse off by entering into a social contract; that the limits to freedom imposed by civil society are more than compensated for by the increase in common weal. In other words, contracting out of a State of Nature is a "positive-sum game" .56 The spirit

Locke (Book I, Ch.XII:sec. 92:5-10).

Plato. The Collected Dialogues of Plato. Eds. Hamilton and Caims. Pantheon, 1961. I am especially thinking about the arguments in the Crito (50b-54d). 
of bonding in civil society dictated the intent and limits of governance within it.

...the main reason that society was formed, according to Locke's account, was to make it possible for individuals to enjoy their own property rights more safely and securely. Thus society's primary task was and allegedly still is to protect private property rights, not to infringe on them. ${ }^{57}$

Locke insisted that it was a rational move for men to submit to the bonds of mutual governance (the State). He believed that they themselves saw and understood the terms as in their best interest. Political power, then, in Locke, is a special form of power which is the power that each individual has in their own independent, natural being, converted, by the action of giving that power up, freely and mutually among two individuals: the "social contract". The social contract that Locke begins with is between two members. This makes political power, it makes a society. We also say that there is a social contract between an actual individual and the State itself, but this is a shorthand account of the relations which are the sum-total of all prior individual agreements. Under this account of political empowerment, besides the "public citizen", another category of persons is created: those individuals who do not enter into contracts with other individuals. These would be non-social individuals. A particular configuration of agency, license, and duty, defines and proscribes the power which comes to be the democratic State. One first creates it, and then one subjects oneself to its authority.

The ontological features of Locke's political power are: 1) it has its origin in the human realm, is created through contract, it is not natural; 2) it is substantive or

Hargrove (1989:66-7). 
thing-like, in that it first resides in an individual, and then resides in the State, which is "made up" of the negotiated and transferred powers of individuals and has power over those individuals; however, 3 ) it is relational insofar as it is created between agents by virtue of their relations; 4) it is abstractly egalitarian: that potentially, all can exercise it, and all are subject to it; and lastly, 5) (a feature unique to this form of property) its legitimacy or illegitimacy resides in the procedures of enactment, not in blood, age or time.

\section{Locke's Theory of Property}

Locke's theory of property mirrors his conception of political power. According to Locke, private property, too, is created by humans. It is the particular enactment of individual power upon Nature whose product is private ownership. His theory is known as "the Labour theory of Value". Property (or value) is created by the act of an individual, freely mixing what is theirs by nature (their body and its energy) with Nature, thereby converting their property and rights in Self, to property and rights in land and things.

Property is natural, since the opposite of natural - artificial or contractual - is not present in original aquisition. There is no rational negotiation between a farmer and a field; it flows from an aspect of their essential being. The possibility of ownership in land and things is thus a natural right potentially enjoyed by all.

But, like political power, the institution of private property is created unit by unit. This patterns political relations of obligation, privilege and trespass between persons, and between persons and the State. Arrays of wealth and obligation may not (in fact, do not) 
conserve the basic egalitarianism among persons which Locke insisted was our Natural state. Holdsworth described the powers of ownership under a Lockean scheme as profoundly anti-social, anti-egalitarian. He pointed out the odd asymmetry built into the mechanism of original acquisition wherein the range of persons against whom an owner could hypothetically assert his proprietorial claim widens..."to eventually recognize that ownership was an absolute right against all the world." ${ }^{3 x}$ In one move, then, in the appropriation of Nature to the Self, a former abstract equivalence between persons is transformed entirely.

Locke's argument for private property has dominated political thinking and the domain of property in the West since the $17^{\text {th }}$ century. One hundred years after its appearance in England, Locke's argument for private property made its presence indisputably known in long passages from Jefferson's Notes on the State of Virginia (1780), and thus in the American Declaration of Independence. ${ }^{99}$ Three hundred years after its first appearance, its terms continue to dominate contemporary debates regarding property: "origin", "family", "autonomy", "equality", "procedural justice", and above all the "natural rights" of ownership workers have in their work -- which is chiefly a right to exclude others from making unauthorized use of that work. All of these are propped up

W.S. Holdsworth. A History of English Law, Vol. 7, 2nd Edition. London: Sweet and Maxwell, 1937:458.

59 Hargrove (1989:67). 
by 17 th-century ontologies of "power".

The contemporary view of "power", however, is not, strictly speaking, any particular view of power offered by Locke or by Filmer. "Power" as it appears in present discourse is an amalgam which seems to have these general ontological features: 1) it is substantive (thing-like: acquired, held, stockpiled and transferred); 2) it is specific: that only some can be, and are, bearers of it: power informs hierarchies; 3) it has an origin and source outside of the individual; it is used, expressed and transferred by humans but not created by any one of them; $;$ ) it and the rights associated with it are sometimes natural, sometimes conventional. ${ }^{[1}$ sometimes private, sometimes collective; and 5) its legitimacy is variously determined: by sheer strength, by family or station, by how it is exercised, distributed, or to what ends it is applied.

My analysis suggests that at the ontological level liberalism does not actually represent a radical departure from patriarchalism. This helps to explain the lack of fit between Locke's "new" conception of power, his theory of property, and the actual patterns of property and forms of social power which have existed since the 17 th century.

The only qualification here would be the idea of individual will and autonomy. It isn't the case that an individual creates this, and that all individuals can and do create this. It seems more accurate to say that some individuals make these individual expressions of power, although the "source" of this is open to debate. If an individual expression of power is voting, then we come closest here to Locke's version of political power.

61

Some would argue that the relations of power, between God and God's sons, was indeed conventional: a covenant with his chosen ones. The original insertion of God's power into the line of humans perhaps can be understood as a kind of convention. Here, the contracting parties are by no means equal or requiring co-operative reciprocity, thus we are closer to a Hobbesian conception of contract than a Lockean one. 
If we all have natural power and rationality, the conditions for the creation of political power and property rights, if by Nature, every human is equally Free and Rational (it is in everyone's interests to create property and political allegiances, and all know this), then how do we explain the stratifications in private ownership (in wealth, in means of production) and in power (in access, in political rights) -- the hierarchical society - that has developed since Locke's political theory has been put into practice? Radical social and political inequalities exist across gender, race, and nations. Does the liberal system condemn inequality, as Locke himself did, or does it contain within it, conditions which excuse and justify these facts? How, exactly, has it come to pass, that persons are subject to authorities which do not, in each and every case, serve their interests? How has it come to be that persons are authorized as owners having exclusive rights to use, who do not, in each and every case, come to have those rights through their own labor or through just procedures of distribution?

Responses to these questions are legion. Some defend states of inequality as the natural, good and legitimate result of a basically just system of power, especially where its mechanisms appear to have been properly enacted. This is the chief view of libertarians and it is concentrated around the free market mechanisms. Where the legitimacy of the "social contract" is challenged, for instance, by persons who in no way played a direct role in the penning of the contract to which they are held, subtle revisions of the terms of procedural legitimacy appear. A key question concerns "tacit consent". Many committed liberals view the present facts of social and political inequality as a 
not-yet-perfected middle phase in the uptake of democratic power, and argue for better formal principles of distribution, and better policing of the Lawless. Some reject the structure altogether as simply the wrong theory, because it has its premises wrong -- not all Men are equal, in rationality, in motivation, in character, and hence, they argue, social inequality is acceptable. Others, radical feminists and Marxists among them, reject liberalism as the most effective means to achieve a just and equal society, though they may share some of its premises and its ideals. From these two critical perspectives comes the suggestion that there is a gap between the liberal theory of power and the "power distributions" such as inequalities in ownership and access rights in a liberal society, because the liberal theory of power does not (can not) adequately account for certain relations of power -- gender and class -- which are in play in every aspect of the social field. Many forms and more nuanced kinds of power and property than the Liberal paradigm "works with" were already in place before democratic revolution, and have simply persisted alongside (hence undermined) the changes that Locke, and others since him, have argued for. A similar analysis has been offered by feminists with respect to the failed emancipatory promises of Marxism; that is, that Marxist theory does not and can not adequately account for gendered axes of power as distinct from and independent of, class-based oppressions. ${ }^{62}$

My reply is an extension of these last replies. We need a more complex theory of

62

See for instance, Heidi I. Hartmann, "The Family as the Locus of Gender, Class and Political Struggle: The Example of Housework." in Feminism and Methodology. Ed. Sandra Harding. Indiana University Press, 1987:109-134. 
social forces within which to embed or contextualize our account of property, historical or otherwise. However, the Marxist or Feminist theory does not provide this since, at the same time as they critique Liberalism, they appropriate its ontological commitments about power. This is a very important observation to make regarding the descriptive accuracy and revolutionary capacity of what appear to be offering, on face value, critical alternate viewpoints. Jayati Lal, an Asian feminist ethnographer, describes the limits that she encountered while trying to put a critical alternative epistemology and methodology - intersubjectivity and standpoint - into practice:

...such constructions have the unintended effect of reinforcing the very distinctions that they are supposed to erase. This is because the construction(s)...are all premised on maintaining the same borderlines...they purport to question in the first place...(S)imply reversing the hierarchy of the original categories...the binary structure remains intact....63

If we start from an entirely novel conception of power than that which is offered in Filmer or in Locke, then we get an entirely different view of the production of inequality. Especially, we see how the thinking about power; the view of power itself is implicated in the production of inequalities. With a Foucauldian ontology of power we see something odd: liberal society has inequality built into it not only because it "sustained" rather than dismantled old inequalities (like Monarchical land holding), but because the system that "replaced" Filmer's system of power was only nominally distinct from Filmer's. In the private realm, it retained most of the basic ontological features, and in the public realm, Text." Feminist Approaches to Theory and Methodology. Eds. S. Hesse-Biber, C. Gilmartin and R. Lydenberg. New York: Oxford, 1999:1 14. 
its same features were now the inheritance of "individuals", not just Adam and his privvy. Moreover, in its tripartite account of power, Locke actually contributed to the erection of the public/private distinction. As we will see in the next chapter, it is the public/private axis which plays a central mechanical role in the domain of property. It is this axis which anchors a set of dividing practices which individuate and delimit visibilities and statements as internal to the domain of property, while excluding others as foreign to it, as non-subjects. In other words, the ontology of power which undergirded Lockean ideas about property was such that the discursive field of property could continue to be organized around a limit, even while it understood and promoted itself as leading toward the dismantling of such limits.

\section{Summary of Chapter Two}

Liberalism and the systems of property which it promotes, promises, at the macro level, to work toward the equality of persons. Property is seen as one of those means. But, at the micro level, different patterns are put into place. The pattern that is present social inequality can be explored as a matter of the way power relations are made possible and happen to be formalized. The models of power built into liberalism are of critical importance. "Underneath" liberalism there are formal relations of power which have supported both the set of liberal promises and the extension of other possibilities which liberalism sees itself as having triumphed over. In the next chapter we will see how the formal features of relations of power which undergird our modern system of property align men\&public and women\&private. While liberalism affirms a political realm as the 
realm of political agency and of property, as a zone of comparable freedom and actualization for all, open to all, it also competes with that same promise by positing a second, 'complementary' zone of power, the parental relation. Although in the theories of power he offered, Locke offered paternal power to men and women by virtue of their roles as bearers and guardians of children, in truth, this "empowerment" has largely been reserved for female parents while the civic empowerment via property-holding has largely been reserved for males. Free men have been patterned as public more than private beings because recognizing and affirming women as the bearers of children, and men as the bearers of titles, fell more squarely "within the true" in the $17^{\text {th }}$ century and afterwards in a way that the inverse did not. A genealogical analysis suggests that this is because the liberal framework itself played a key role in the domain of property as one of the sciences which began to "refer" to it, thus lend it its ontological commitments. 


\section{Chapter Three: The Public and The Private}

Introduction:

This chapter focuses on the "Public/Private" distinction. These two categories serve as a ground zero for a number of discursive domains including health, sexuality, work and property. They are a key binary (not unlike Self/Other) according to which domains can begin to be divided. While the public and the private are sometimes taken to be distinct foundational categories, they are in fact relational and produced by mechanisms of inclusion and exclusion. Yet this axis is more primary than other axes which other views of private and public are predicated upon. That is to say that while they themselves serve as one of the basic axes for inclusion and exclusion, this capacity has been built up, and continues to be maintained, through a variety of dividing practices. These dividing practices organize daily life insofar as its particularities - ownership, health, sexuality, identity - can be rendered into either public or private aspects. Naturally, a Foucauldian view of power explores these underlying constitutive mechanics. Practices of inclusion or exclusion always function through a matrix of power relations. Power is the condition of the possibility of excluding or including, marking or being marked. "Property" is nothing other than a particular form of space and techniques of marking, nothing other than domain-specific forms and relations of power. Property is first the thing marked and then what can be done to put this into other relations. Thus relations of division precede relations of hierarchy or equality since something must be divisible before it can be arranged. A focus on the mechanics of the dividing practices 
which establish the private or the public - the techniques and objects used to inaugurate and sustain a distinction - is the next step in our investigation of property.

Land therefore, is not necessarily the most basic paradigm of property: whatever relations inscribe the land so that it can function as property are. In this chapter I will focus on states of the body and on the potlatch, to show how they are more originary paradigms by virtue of their marks and spaces. Power is a specific, local on-going relational condition of making and holding property, not produced as a collateral, individuated AnyMan effect we heard in Locke's account.

Practices of making the private and the public are historical, anthropologically diverse, and are made to apply to multiple kinds of property. If the public and the private could not be constituted first and foremost as distinct, private property itself could not be derived as an apparently distinct sociocultural phenomenon. More specifically, it could not be constituted as one of the central values of the liberal, enlightenment project. In this chapter we will continue to consider the political and ethical significance of the public and the private from the point of view which suggests it is the Lockean/liberal paradigm which has supplied and continues to supply those wider moral and epistemic relations and the means of differential marking. As we saw in Chapter Two, Locke articulated a private as distinct from a public form of power at a particular moment in a particular political debate; that is to say that the public and the private take on an identity as part of an historical event. Locke did not simply release an inevitable natural form "waiting to be 
expressed".' Private property (and the inequalities of distribution which are its inescapable problematic) is an on-going effect of a discourse which posits the private as fundamental, and which justifies it by invoking those values which name private property as one institution capable of respecting the deepest truths about humans, both as individuals and as a social body.

The first part of this chapter argues against attempts to ground the public/private distinction in a feature of space and in particular activities of the body or the soul. I use my own experience of pregnancy, childbirth and motherhood to disrupt a foundationalist account of the public/private split. My transitions from not pregnant, to pregnant, to childbirth and early motherhood were thoroughly inflected with the public/private. I explore how the many ways we tend to distinguish a private from a public admit of exceptions. I try to identify what forces and in which ways these play the role of delimiting a public from a private, and extending the nature of the private.

The second part attempts to establish the positive claim, by way of a second example, that the public and the private are discursively produced. I will use the example of potlatch economies to illustrate an alternative way in which the public/private distinction is drawn and invested, and to show how that distinction shifted as those societies interacted with Europeans. The reader must bear in mind the following in order to understand why this example is introduced: Potlatching societies operated according

Joan W. Scott, "The Evidence of Experience." Feminist Approaches to Theory and Methodology. Eds. S. Hesse-Biber, C. Gilmartin and R. Lydenberg. New York: Oxford, 1999:92. 
to a unique set of sociocultural rules, and those rules did not appear to require or include the public/private binary. This is particularly true of its commerce or economy, which in the West is considered the definiendum of public activity. Potlatch societies were rapidly transformed into capitalist society with its particular public/private division. This offers us an historically bound, rather than a universal example. What we are looking for are the kinds of conditions and mechanisms which coincided with an absence of the public/private division as we know it, and then the kinds of conditions and mechanisms which coincided with the emergence of this division.

While I offer specific historical and personal evidence in support of the more general claim that the public/private distinction is discursively produced, I'm not suggesting that these specific experiences or events are replicated for all potlatch societies or for all experiences of pregnancy. The social responses to pregnancy and women's phenomenologies of pregnancy will vary enormously from woman to woman. I do wish to illustrate by way of these examples, that problematizing the public/private distinction is warranted, and that a microphysical analysis (however specific) can go quite a ways to explaining what is going on in these examples. In the potlatch practices of property, and in the experiences of pregnancy, this very distinction acts to divide spaces into inclusive and exclusive ones, and mark persons and behavior as legitimate and illegitimate. The differentiation of a unity into a binary operates according to certain identifiable microprinciples. Using historical and contemporary examples, we will at least be able to see how the possibility of making the public/private division relies upon: 1) a wider set of 
moral and epistemic relations, and 2) specific means of marking, circulation and surveillance. I hope to establish that the public and the private are produced through these practices of exclusion, rather than being prior natural categories which are honored by exclusion and inclusion.

I also hope to make two other related points. First, that the assertion of the public or the private has political effects whose gains and losses are not distributed evenly across the socius. This should not be lost sight of when we arrive at our evaluative questions about current property modes. Second, demonstrating the Foucauldian principle that the production of knowledge and the production of subjective authorities are entailed by practices of inclusion and exclusion, I wish to draw attention, in both examples, to the ways that knowledge plays a key role in the production of private and public. In particular, I want to highlight the complex possibilities of freedom and oppression involved in the establishment of a personae of expertise. This is very important for coming to understand (among other things) women's relations to property and to the private domain. I will focus particularly on the power/knowledge relations of women to the truth of their pregnancies and to the realities of mothering, to organize and offer maternalist narratives. These authorizations help to explain the uptake and expansion of the private in the lives of women during and after pregnancy. There is a dynamic here which,

...gives itself credibility in the name of the reality which it is supposed to represent, but this authorized appearance of the "real" serves precisely to camouflage the practice which in fact determines it. Representation thus 
disguises the praxis that organizes it.?

It appears that the subjectivities who can claim expertise in the private domain are not necessarily the same ones who appear viable as public subjects. In the next chapter, I examine this production of subjectivities of property in greater detail.

\section{The Public and the Private: Politics, Property and Dividing Practices}

The "public" and the "private" were linked as a pair in ordinary language and within the Western political tradition well before they settled into a dyad as distinct forms of property. Since the public/private distinction can be closely aligned with legal and political enfranchisement -- especially when this concerns the holding of property -theorizing property usually means, one way or another, dealing with how the public/private are involved in gaining or preventing equality.

This subject -- the public/private distinction -- has been broached by most major 20th-century feminist political theorists. This is because gendered legal and political enfranchisement -- including concerning the holding of property .. can be correlated to the relegation of gender to these so-called separate spheres. Gender and the public/private tend to fit together in a way which challenges the classic liberal promises regarding individuals and power. Joan Landes summarized the three central questions entertained by feminist theorists:

Feminist theorists want to know whether the public/private distinction is universal, how it has emerged with singular force in certain times and

Michel de Certeau, "History: Science and Fiction." Heterologies: Discourse on the Other. Trans. Brian Massumi. Minneapolis: University of Minnesota Press, 1986:203. 
places, and not least, what accounts for the stability and instability of the boundaries that separate these regions of social life." 3

In attempting to answer these three questions, this section queries the emergence of the public/private distinction in specific "times and places" in my life. "The public/private distinction" has played a role in my own actual experiences of having been relegated, or of relegating myself, physically or attitudinally, at different moments and with different cues, to different social spaces. The "female experiences" that I am going to use as examples of "specific time and place", to read the play of the "public/private" are pre- and post-pregnancy. A term that I will use for this set of experiences is "natality".

The trends which tie the private to the feminine need to be checked for whether the alliances is natural or constructed. This applies not only to the gender terms, but to the location terms, as well as to the indexed relations between them. Moreover, this critical question must be applied to theoretical frameworks that make use of this same alliance. Using micropolitical analysis, what we will discover in the example of pre- and post-pregnancy is that the public/private distinction is indeed not universal; that it emerges with "singular force" at certain times during my pregnancy and disappears at others, because of how "the female" and "the private" get paired in power relations. These shifting relations of power can account for the rapid instabilities of the public/private boundary across the pre- and post-pregnant phases. I use this example therefore, to University Press, 1998:3. 
illustrate the ways that these categories (in both experience and theory) are posited as foundational while being extended. Politically speaking, this extension has great significance for women both in terms of the experiences of pregnancy as well as ownership.

\section{Part One: The Natalist Series}

Although there have been volumes of excellent writing, both descriptive and theoretical, about the public/private distinction operating in three distinct phases of natality: 1) the temporary female embodiment called pregnancy; 2) the varied experiences around childbirth itself; and 3) post-partum maternal relegation to the private, I would like to focus on these as a series. There is a topography to this series which is not readily visible if we examine these phases of motherhood as isolated parts. When made visible, it throws into relief how natality comes to be reconstituted as a unity through "continuous history",

...the indispensable correlative of the founding function of the subject: the guarantee that everything that has eluded him may be restored to him; the certainty that time will disperse nothing without restoring it in reconstituted unity. ${ }^{+}$

When I was known to be pregnant, and when I was visibly "with child", the strongest cultural and personal pressure on me (and which I took on or exerted on myself) was to remain within the home; the one notable exception being the necessity of going to a clinic for a series of carefully scheduled visits with a medical professional (an obstetrician).

Foucault (1972:12). 
This accords with what Rayna Rapp calls "the extreme privatization of the experience of reproductive choices." However, as a woman in labor, there was the expectation that the responsible/ appropriate/efficient/wise thing to do would be to leave the home and have my baby in a public institution, a hospital. ${ }^{6}$ Yet, next, as a new mother with newborn children I was expected immediately re-enter and thereafter remain for the most part and for a significant amount of time, within' the private domain with my children. ${ }^{2}$ Again with

Rayna Rapp, "The Power of "Positive" Diagnosis." Feminist Approaches to Theory and Methodology. Eds. S. Hesse-Biber, C. Gilmartin and R. Lydenberg. New York: Oxford. 1999:290.

6

This perceived personal expectation reflects broader social trends. Paula Treichler indicates, statistically, that in 1900 there were $5 \%$ of hospital births in North American, and in 1981 , there were $4.4 \%$ home births. ("Feminism, Medicine and the Meaning of Childbirth." Body/Politics. Eds. Jacobus, Fox-Keller and Shuttleworth. New York: Routledge, 1990:113). I should note that hospital births in Quebec, at that time, were paid for through Medicare, where home births were not. There were, therefore, economic factors in the decision as well.

7

The allotted time and space for this necessary hospital birth is getting shorter and shorter. On the one hand, women are being urged to remain at home until later into labor (and this is being facilitated in Ontario by the increased use of midwife or labor-support services, who help the woman, at home, in early labor. On the other hand, women are being urged to return home sooner and sooner after delivery. Whereas in the 1950's it was not unusual for a woman to remain in the hospital for a number of days, now that has been shrunk to, in many cases, a number of hours. What is it, of that public domain, which, in that experience, consists of an essential but necessary difference from the home environment? What do spaces offers the woman/child such that a responsible woman must enter one space and leave another, sometime over a matter of hours, for the birth of that child? The most obvious empirical answer is the proximity to high-tech equipment and licenced professionals coincident with the need or the increasing probability of the need to use those professionals and that equipment during the experience of delivery. However, this answer shouldn't so easily satisfy us. Since most deliveries do not require high-tech equipment (only $2 \%$ are labeled high-risk early on in pregnancy, numbers which do not line up with the demand then to enter high-risk tech-availability zones) then perhaps the presence of delivering women is necessary for the machines (the fetal heart monitors, forceps, narcotics and oxygen) rather than the machines necessary for the deliveries. Similarly, since the pregnant woman has been delegated the primary caretaker of the infant during pregnancy, and then again immediately after birth; that is, as the professional, perhaps the entry of the pregnant woman into a medical situation and present to a gynecologist makes that second individual the professional, an ideological product rather than an historically real. Perhaps the gynecologist "does not precede the work(s); he is a certain functional principle by which, in our culture, one limits, excludes, and chooses; in short, by which one impeded free circulation...composition.." (To paraphrase Foucault on the author function, "What is an Author?" The Foucault Reader. Ed. Paul Rabinow. New York: Pantheon, 1984:1 18-1 19). Later in this chapter, I will explore what power relations are there in labor which establish and naturalize, however briefly, and according to what method, and what subject constructions, the personae of the laboring woman \& the gynecological professional, and the proximity to surveillance recording devices/medical paraphernalia as central to the drama of parturition. 
the one notable exception was that I was to bring the children to the medical specialist (the pediatrician) for a series of scheduled visits.

The locational series was private-public-private. There was another series regarding the kinds of relations considered necessary/appropriate/efficient between the children, myself, and the rest of the world. As I indicated, during the pregnancy, there was a professional, public authority (either the doctor or the midwife) who mediated the relation between the developing babies and myself. During the labor, public figures took up an even more central position in mediating the experience.9 And yet, immediately after the birth of the children, these relations were instantly reconfigured. This time is a new, unmediated "critica! period", where

new mothers (whether they felt like it or not) are instructed to engage in set amounts of postpartum flesh-against-flesh intimacy...to ensure that "bonding" takes place. ${ }^{10}$

One pregnancy, two babies: I had twins. I would like to eventually extend this analysis to include the broadest range of natalist experiences: the actual and potential states of pregnant and non-pregnant involving surrogate motherhood, fertility treatments, menopause, menstruation, abortion, adopting out, or miscarriage.

9

Treichler (1990:135, $f n 10)$ assembles medical textbook definitions of labor, most of which do not indicate the presence of the woman at all, but instead, describe the interaction between the overseeing obstetrician and the baby. See also Emily Martin, "Science and Women's Bodies: Forms of Anthropological Knowledge." Body/Politic. Eds. Jacobus, Fox-Keller and Shuttleworth. New York: Routledge, 1990:69-82, for an account of the way language makes certain aspects of female bodily experience invisible and unknowable.

10

Sarah Blaffer Hrdy. Mother Nature: A History of Mothers, Infants and Natural Selection. New York: Pantheon, 2000:486. 
As this post-partum period extended into full-fledged motherhood, these same pressures

were extended to include the expectation that the responsible/appropriate/wise thing was to not have some other primary caretaker brought into the home. "Nor that I would place my children in the hands of a public institution such as a licenced daycare facility. This series is public-public-private.

What can account for the radical, abrupt shifts in relational and spatial commendations I received, and acted out, during the three phases of natality? Are these substantively related? Are they related to a politics of the public/private distinction, even if they do not construct an actual, simple public/private distinction?'12 I believe that they are. To try to make a supporting case for this, I enumerate and critique the ways in which the public/private is presumed to be distinguishable according to spatial and relational 【I

I am including the father in my case as a co-primary caretaker. I believe that he was probably subject to the same kinds of pressures, in the same order. And that we both exerted these pressures on each other.

12

I realize that there are many other significant sociological, psychological, material and symbolic criteria, differing across different phases of pregnancy and childhood, which could help to account for these series, including: hygiene, technology, morality, family, education., wealth. I don't discount these, but want to investigate how these play a role in the designations of public and private themselves, and in sometimes abrupt, discontinuous, and irrational, rather than continuous ways. For instance, consider the principle of "hygiene". Asked to account for the approbation of hospital births over home birth in regard to the question of hygiene, the standard strong assertion is that a hospital birth is more sanitary than the average home, and therefore, since we want health and hygiene, for both the laboring mother and the newborn, the baby and mother should be in the hospital. This assumption, about the benefits of hospital births over home births, in terms of infant and maternal sepsis, has resisted empirical counter-arguments which demonstrate that there were in fact epidemics of maternal and infant death as a result of hospitalization for labor, prior to knowledge of germs. (See Alcoff and Dalmiya, in Alcoff and Potter: 222-223). However, even more interesting and notable to me than whether counter-arguments shift the larger public perceptions about one particular aspect of the natalist series is the fact that, even in the same series (historically, personally), the question of hygiene rarely resurfaces with respect to the argument for daycare over home care. Technically, where day cares are licenced facilities we should be prepared to run it here, again, in favor of institutional settings for young children. What I am calling "odd" in the series is the way in which, when laying the phases back to back, the same arguments and principles surface here as primary, then are completely discarded in the next moment. It is this play which forces us to rethink that the public/private is enacted, rather than entered into. 


\section{foundations.}

\section{A: "Public" and "Private" Do Not Designate Distinct Spaces}

The terminology used, both in common parlance and in political theory to indicate the "public" and "private" as two distinct categories, draw upon, above all, spatial imagery. The "public" and the "private" are indicated most frequently by the terms: "spheres", "domains", "zones", "worlds", and "arenas". More specifically, the adjective which precedes any of these is the word "separate". Think of an image of "separate spheres". It is a Venn Diagram, with two circularly demarcated sets, non-intersecting. overlapping. If they were overlapping, it would be inaccurate to use the designate "separate". These spatial metaphors help to naturalize these two concepts as distinct and as discrete, since two different things, which qualify the kinds of spaces themselves, cannot occupy, by definition, the exact same spaces.

Susan Moller Okin, in her well-known essay, "Gender, the Public, and the Private", points out that although used as if unambiguous, even at the conceptual level, the term "public/private" designates two very different zones. On the one hand, "public/private" is used, especially within socioeconomic discourse, to indicate the split between the state and society, where, for instance, we would differentiate "private" from "public" (State) ownership. On the other hand, the same set of terms is used to refer to the divide between domestic (home, family, intimacy) and non-domestic (outside-the-home, stranger, community, citizenry, publicity) zones of experience. Okin points out that, in both, it is the family or the home which is that which "is or forms the paradigmatic 
private zone". ${ }^{13}$ This seems true across common and academic usages of the terms. As one part of a spatial dualism, the family, the home, therefore must be a particular physical location or a particular arrangement of particular bodies which is capable of excluding (to a critical level), the entry of non-home, non-family spatial elements.

Is it the case that experientially, the home or the family is that real locale which anchors "the private" and excludes "the public"? Speaking from my own experiences of my movement in and out of different spaces, it isn't the case that there is a strict, dual nor even spatially distinguished set which corresponds neatly to these terms. My home toggles between being more or less private, more or less pubic, depending on literally hundreds of factors, including my age, my financial situation, whether it is a weekend or not, the temperature outside, my moods, my health, whether I have a lover or not, the size of the roadway that it is built on, whether or not what I am doing inside my house is legal or illegal according to civil code. Many would argue, that despite its apparent openness, there remains a core to this zone called home, or that there was one before I decided to take liberties with it, or even that such a core exists symbolically in that home: an essential space -- usually my bathroom or my bedroom which makes me, then and there, an essentially private being. What about the bank book that I keep in a special place in my bedroom? The bank book invokes the sphere of economic liberties, a sphere of 
activity which Seyla Benhabib claims is the epitome of the private. ${ }^{\text {t4 }}$ But there is nothing in my bank book which wasn't first put there by someone or something absent from anything we would call private: it is an entirely public object, keeping track of a set of possibilities which are distinctly non-intimate, non-familial. ${ }^{\text {s }}$ Merely habitually storing it in the top drawer of one's dresser doesn't change its nature to something private. Only if we stopped thinking of it, and treating it as a highly private object (by virtue of, and always against the gradient of its significance in the public world), would it come to simply be a neutral object in the home. But then it would have ceased to be a designating, essential object of a home, of a private individual. It could just as easily be a piece of paper slid, inconsequentially, between the socks.

We could make a similar dissection of the location known as the bedroom, looking for its uncontingent, privacy-generating capacity. We would discover that, if taken independent of the set of public (religious, moral or legal) rules which qualify a bedroom as a private-zone, then that room would be a neutral space, and no longer the private space which it is taken as paradigmatic of. The private, conceptually, depends Habermas." Feminism and Politics, Ed. Anne Phillips. Oxford: Oxford University Press, 1998:85. together, and only during the phase of human development subject to the new forces of surplus value. The institutions of the private (self and family) are distinguished from the activities of trade by virtue the possible activities of trade. The bank book seems private but it is deeply public because it keeps track of my need for something other than myself. 
upon the invocation of the public. They always appear together, as a mutually exclusive, but mutually dependent pair. We cannot produce a value scheme in favour of the private or the public, therefore, which presumes that one is primary and the second, derivative, among human experience. A supporting observation is made by Treichler in her work on the meaning of childbirth. She notes that the kinds of efforts made to render hospital birthing rooms "homey", the introduction of elements of "home" (comfort, soothing) into the birthing room -- wallpaper, cushions and framed pictures -- neither represent "the home", nor could be made to at any substantial level within a room which is the space which functions in our present culture, precisely as non-home. ${ }^{16}$

Spaces are not by nature public or private. They can function as public or private. Any location can be made to warrant the respect for privacy (even independent of a definitive act or locale of privacy) or made to warrant its general disregard. This has nothing to do with the space itself, but everything to do with how it stands in sociocultural relations, including (but by no means limited to, or dominated by) race, class and gender. This seems to offer a reading the locational series for my natality: the movement from the home to the hospital to the home again. None of the specific places I found myself in, provided, by nature, a private or a public place. My experience of whether those were private places or not had more to do with extrinsic factors (my health and the health of the children, hospital ward policy on breast-feeding, number of into a non-home space since these two are constructed via conceptual opposition, rather than a set of distinct things in the world. 
family members in town, size of my apartment, my marital status, pain level, the language spoken) than with the location. A striking, supporting example of the discursive production of privacy- or publicity-effects in homes is described by Michel Foucault in The History of Sexuality.

Foucault is interested in how the longstanding universal prohibition against incest came to be included among the typical degeneracies of the poor. The facts of "incest" can only be deduced, since sexual intercourse between kin takes place (by definition) among kin, not among strangers, or while they are in full view. What is really going on in private can only be inferred, since being privvy to something makes it public. Early social service agencies, backed by Church and State (particularly psychiatry), organized a campaign against incest.

An intensive administrative and judicial grid was laid out to put an end to these practices. An entire politics for the protection of children or the placing of "endangered" minors under guardianship had as its partial objective their withdrawal from families that were suspected.... ${ }^{17}$

Evidently, this campaign would have important ramifications, both for the detectees and those whose suspicion was cleared. Foucault reports the "finding" that the poor were worthy of suspicion, therefore they were subject to inspection and intervention, but that the rich were not found deserving of suspicion therefore their privacy was left intact. The intelligibility of incest, in the absence of proof, was transferred to an indicator of its possibility. That indicative possibility was the number of related persons to a bedroom;

Foucault (1980a: [29). 
that is, the physical distance between sleeping members of a family. ${ }^{18} \mathrm{Clearly}$, that indicator alone cannot be said to provide evidence of incest. But Foucault claims that it does produce knowledge about incest. Being already class-bound, it is infused with power/knowledge and produces as its results a spatial locale of incest (the bedrooms of the poor), a set of dubious persons who do not deserve rights of privacy any more in those spaces, and "the private" as whatever the rich do which is not inspected.

So much for the "private space" of home. Consider now whether or not the public space provides us with some essential locale of publicness. Moving around in what is called public space rarely means one is automatically removed from the private. The private needs to be navigated as it often suddenly appears there, sometimes as a set of gestures specific to another cultural landscape, often some place not essentially zoned as private. When you happen upon a couple having an intense argument or making love, you give them some berth. Sometimes, a phone conversation within earshot changes its subject, not always to something sexual or emotional, but suddenly you are present to something, which, while there has been no geographical shifts, has changed the nature of that space temporarily. I can think of a number of extremely public-seeming, public-character institutions which procure and defend spheres of privacy with as much or more vigor as the privacy of the home is ever defended. I am thinking here of the voting booth, and the long-standing tradition of anonymous newspaper editorials. Like the example of the bankbook, the space inside a voting booth or reserved for public

(ibid: 129). 
opinion in a newspaper is quintessentially public: the touchstones of civic-mindedness, the places anyone, any member of the civic society (the abstract, rather than the private individual), can and must occupy. But "inside" these almost perfectly public zones we do something entirely private, exercise a set of possibilities which approach intimacy indicating personal intention on a ballot - and are often distinctly familial, if not vaguely tribal. ${ }^{19}$ Conversely, the workplace as public sphere distinct from the home as non-public sphere is becoming less and less of a distinct spatial reality. With the advent of the decentralized modern workplace, with laptop computers, faxes and car phones the boundaries between the office (being "at work", being subject to federal or managerial rules of conduct) and home (being "away from work", being free from such interventive regulation, being able to "be oneself") are dissolving. The sureness with which Locke articulated a discontinuity in public and private power cannot be easily mapped onto a discontinuity between private and public spaces. In the exercise of voting, among liberals the act most assuredly in the spirit Locke's political power, this clarity is not evident. In the exercise of business or economics, there is not a spatial separation of a public from a private which is not already undergirded by a set of power relations which make those appear, in certain times and places, and with certain kinds of individuals, distinct activities.

B: Public and Private Do not Designate Distinct Relations between Persons.

19

Charles Franklin, "Issue Preferences, Socialization, and the Evolution of Party Identification." American Journal of Political Science 28 (August, 1984):459-78; Margaret C. Trevor, "Political Socialization, Party Identification, and the Gender Gap." Public Opinion Ouarterly (April, 1999):62-89. 
Many would not be troubled by the inability to distinguish, as independent and fixed, public from private physical locales. They would likely suggest that what is private and what is public can be discovered in the fundamentally different nature of the relations between kinds of persons: that the presence of kin relations operate to comprise (and largely locate) the private, and that the presence of non-kin relations operate to make up (and locate) the public. This was likely what Locke had in mind when he declared "paternal power" an altogether distinct kind of power, unique to the private reaim. Does this possibility help me to understand my pre- and post-pregnancy experiences?

It doesn't seem so. Consider the arrangement of bodies (and genes) North Americans call, the family. The family is not self. The incest-taboo demands that sexuality (a mechanism for biological family) must be outward tending (exogenous). Desire must be disjunctive. The family is not a stable, ahistorical phenomenon. Rather, it has its origins in non-sameness groupings, or non-familiarity..$^{20}$ Evolutionary biology and genetics distorts "family" as a relatively unified locale when it maps degrees of genotypic relations as family trees. A genotype traces the vertical lineage and branchings of a series of cross-generational kin productions. Certainly, one's biological family can be comprised of these vertical lines of origin and filiality. Let us remember here that these are degrees of relatedness, not absolute relatedness, so even along this axis, the self as a locus of the private cannot be neatly severed from all non-private selves, and smoothly joined to all University of Minnesota Press, 1977:139-273; Sigmund Freud, "The Savage Dread of Incest." Totem and Taboo New York: Vintage Edition, 1946:3-25. 
relatedly-private selves. If a baby's birth is a private event, it should ideally be closed to the parents and the child. But the father and the mother of any child are, biologically speaking, fifty percent stranger to that child. The child emerging from the body is fifty percent genetically unrecognizable. The parents are themselves perfect genetic strangers to one another.

Not only are there multiple rather than single biological "origins"2t to "a family", but the messy, lived (rather than ideological or symbolic) plurality of experiences of family involve more than these vertical lines. And in greater proportion, since the number of kin relations established horizontally, family alliances built among perfect strangers, outnumbers the vertical (generational) relations persons come to identify and experience as "family". Moreover, there are fully non-biological definitions of family working within North American culture (lesbian-headed families of adoptive children, for instance), and in other cultures ${ }^{22}$. Thus,

There is...the definitional problem of just what sorts of relationship count as a "family". With some justification, perhaps...cannot throw the honorable mantle "family" over every ad hoc collection of persons who happen to be under one roof at the same time. But where legitimately to throw the mantle is not clear...given the great diversity of what have been

This, depending on whether one traces downward or upward, and whether one "counts" the maternal or paternal lines as true. The tendency to read downwards, from one origin, and along the patrilinear, is a vestige of Judeo-Christian thinking.

22

See Gender in Cross-Cultural Perspective, $2^{\text {nd }}$ edition. Eds. C. Brettell and C. Sargent. New Jersey: Prentice-Hall, 1996. 
and continue to be taken in different cultures and eras as families. ${ }^{23}$

It is "identifying and experiencing as family" rather than a definitive form and content of family which is behind Locke having distinguished "parental power" from "political power". Parental power is that kind of power which describes the relations of duty and privilege between non-equals: those dependent and those who are able to look after another. "These two powers are so perfectly distinct and separate; are built upon so different Foundations.... ${ }^{2+}$ Locke's best case is the natural inequality between a baby and her parents. From this, he gets the name "parental power". But it isn't the case that parents or children exhaust the possible parties who would qualify as unequal and standing in relations of duty and privilege. Nor is it the case that all children and all parents stand in absolute non-reciprocal inequality to one another..$^{2 s}$ "Childhood" and "parenthood" are not monolithic categories. Like "family", when these are view from different angles -anthropological, historical, gender, economic, race, sexuality -- very different accounts of

Mary Dietz, "Citizenship with a Feminist Face." Feminism: The Public and the Private. Ed. Joan Landes. Oxford: Oxford University Press, 1998:50.

24

Locke (Ch.VI:sec 71).

25

Jessica Benjamin gives a psychoanalytic account of the mutual dependence of child and mother in the construction of each of their subjectivities. The child is relatively unequal to the mother, but neither can afford (materially, existentially) to break from the dyad (The Bonds of Love. New York: Pantheon, 1988). 
each come into focus. ${ }^{26}$ Unequal relations are ubiquitous. They aren't necessarily bad, nor can they simply be twisted and flattened into a relation of equality. ${ }^{27}$ What they do need is a conception of power which fits inequality, and which assigns responsibility to these. This is what Locke offers.

Anyone who, on the one hand, satisfied Locke's conditions of capable (of taking on or creating a dependent) and rational (able to guide, educate or train), and on the other hand, demonstrated the conditions of Nonage and Dependency, regardless of how that specific pairing came about, could be said to supply the Foundations upon which this version of power could operate. Locke was careful to express that this power did not fall simply to the Father, by virtue of being a Father: he repeatedly underlined that the Mother could fulfill this role. In fact, Locke explicitly downplayed the role that mere biology

("Natural family") played in these relations of power:

Nay, this power so little belongs to the Father by any peculiar right of Nature, but only as he is Guardian...and it belongs as much to the Foster-Father of an exposed Child as to the Natural Father of another: So little power does the bare act of begetting give a Man..... ${ }^{2 x}$

The ontological features of paternal power, as we saw in the previous chapter, describe a

Phillipe Ariès. Centuries of Childhood: A Social History of Family Life. New York: Vintage, 1962. which exist inside it (The Mermaid and the Minotaur. New York: Harper Collophon, 1977). 
relationship well-illustrated by the parent-child dyad, by "the natural family". But this relationship could be satisfied by others: it is not essentially restricted to family and blood. It is common after Locke to read his distinction between paternal power and political power as confirming that the family is the private, and these are distinct from non-family and the public. ${ }^{29}$ This has been used to carve out the classic liberal position on the primacy of the biological family, its sanctity and independence from the State. Some have further used this to argue that the family must ground politics. ${ }^{30}$ But, in Locke it is neither family nor blood which comprise the essence of the private. In Locke's view, the private is distinguishable from the public micropolitically; that is, with respect to the presence of a certain kind of relation: one which is unequal, but temporarily, and reversible; one which involves mutual support and obligation, but not necessarily articulated in legal contract; one which is initiated unilaterally but not arbitrarily. Relations built on terms of guardianship, as we know, are not restricted to the "private" realm nor to specific identity pairs. That they have become restricted to certain kinds of places or sedimented in habitual arrangements of persons, and that we experience these as a kind of expectation, is not a matter of what is called 'family' grounding this sedimentation, but a function of claims about the capacity to know what's best for children. It is this authority which divides a public from a private and also that which can Hannah Arendt. The Human Condition. Chicago: University of Chicago Press, 1958. 
account for a disruption of this division during childbirth. I will pick this thought up again in the last section of this chapter.

\section{C: Bodily Attributes Do not Designate the Private or the Public}

After locales and relations comes the idea that the private is not something inhering in homes or families, in places or in kinds of persons, but that these are private or public by virtue of some other truths about bodies: The body is that thing which is also a space, and which is entirely, essentially non-public. Bodily function and one's natural, exclusive property in one's own person is the fundamental locus of personhood and privacy." Obviously, since the body changes (as in the case of pregnancy, gender and age) and is portable, perhaps it is this which accounts for the apparent private nature of some experiences we have in public zones. Does the basic nature of bodily reality perform the roles of the disjunctive (according to which a fixed inner world and a fixed outer world can be separated), and of synthesizer (such that the experience of the body itself is one of a unified private subject, a Self, in clear contradistinction to public object, all Non-self)?

First, the locus of privacy cannot be the total body in virtue of its mere physical facticity: bodies (our own and others) are not inviolable, but porous, receptive and largely functionally neutral. Sexual intercourse and digestion are two examples which highlight this. It must be some refined aspect of "bodyness", some unique capacity of the body to 
receive and to signify, which isolates what is distinctly private, what is not generically public. There are two lines of thought that could be pursued in order to track down that locus in "bodyness".

The first comes from the theological tradition of conceiving the human body as the receptacle for the inner human soul, where that soul as the true locus of Self and domain of privacy. This is the conception which recalls Benhabib's third characteristic sphere of privacy, that of moral and religious conscience..$^{32}$ The second reply is simply that "certain activities" of the body are, by nature private, and must remain so, while other activities the body performs are, by nature, public, and equally, must remain so.

Pregnancy is an example of the former while buying and selling are examples of the latter. Each of these three accounts of the centrality of the human body to privacy can be challenged on different grounds. We will examine the first two briefly, and the third reply in detail.

\section{The Body is the House of the Soul, which is therefore Most Private}

Let's begin with the claim that the body is private because it is the house of the soul, which is the truly private. This is the fundamental locus of selfhood. On this account, anything which is not soul, including the body which houses it, is at a distance from this private being. This "distance" is ontological. However, the private is often spoken of as a kind of spatial dimension, as that which is inner, which is exactly not at a

Benhabib (1998:77). 
distance from the Self.

The true nature of the soul and its relations to the body isn't a mystery I intend to solve here. I would merely like to mention two recent replies to this "mystery". First is Foucault's. Foucault's work inverts that historical, functional relation of the body and the soul, as these concepts have been made to work within these discourses. According to Foucault, the soul is not imprisoned in the body, but, if anything, the body is imprisoned in the soul. ${ }^{33}$ By this he means that it is not the body which has some given and blank reality, yet carries an anterior, interior immaterial, more important entity (the soul). But that "the soul" is produced, made real and confirmed on the surface of the body by the exercise of power which compels that body to show that which it is purported to contain. The doctrine of the "inner" appears as a central premise in discourses of psychoanalysis, historical method, sexuality, criminality, madness. Susan Bordo, making use of Foucault's inversion, claims a causal link between a culture of female neuroses (compromised will, absence of autonomy \& self-control, self-loathing) and the real, often tortured shapes that young females take up as their bodies. ${ }^{34}$

Soul-showing proves the inferiority of the body (by producing the effect of a soul

Michel Foucault. Discipline and Punish: The Birth of the Prison. Trans. Alan Sheridan. New York: Vintage, 1979:30.

34

Susan Bordo, "The Body and the Reproduction of Femininity: A Feminist Reappropriation of Foucault." Gender/Body/Knowledge: Feminist Reconstructions of Being and Knowing. Eds. Susan Bordo and Alison Jaggar. New Jersey: Rutgers University Press, 1989:13-33; “Reading the Slender Body." Body/Politics. Eds. Mary Jacobus, Evelyn Fox Keller and Sally Shuttleworth. New York: Routledge, 1990: 83-112. 
which is more real) and its indispensibility to the demonstration. The body cannot show or be made to be what is immaterial. So, the body suffers the constant violences of having to signify an absence, and in signifying what is supposed to not be present, being trapped by that signification as requiring more enforcement. This enforcement comes from without and from within. Judith Butler suggests that the fleshy body is not made to signify a soul but that it too is a kind of on-going discursive figuration, a created surface which can be made or used to produce certain further effects. For Butler, this includes the performances and activities such as pregnancy, which is the body being made to show a deeper, truer "femaleness". ${ }^{35}$ Regardless of whether we agree with Butler on the question of female or male soul/body discursivity, given the fact that the ontological status of the soul and the body, and the relation between these, is not yet a settled question, we should not accept at face value the claim that the soul is the locus of the self and is located in the body.

All this talk of soul will strike secular minds as beside the point. However, everything that I have said about the relation of the body to the soul, and the dynamic of this in the production of a discourse of the inner self, can be applied to the relation of the body to the so-called mind. My task in this thesis is not to prove or to disprove the ontology of the mind in relation to the body, and these, in relation to the production of a self which could be said to be private, or separate from all else. What I would like to do is

Judith Butler. Gender Trouble. New York: Routledge 1990. See also Jana Sawicki, Disciplining Foucault: Feminism, Power, and the Body. New York: Routledge, 1991:esp. 62-66. 
to suggest that, like the question of soul, the concept of mind can be understood as (among other things) the upshot of discursive play which suggests mind and makes use of the fleshed body to display the fact of inner self for a variety of ends. It is in the demonstrations that the body is called to perform, that the individuated and thus private mind of the individual - his or her thoughts, ideas, notions, intentions -- is constituted as a discursive object. Within a field of power, what is important is not so much the prediscursive status of either mind or soul, but the means and efficacy by which that fact can be registered as, or performed as, belonging to one individual rather than to another. Within the discursive field of property, this is also the case: private property in land and in ideas is conceptually dependent upon the ability to agree upon and to show a private self from which this property arises and thus to whom this property belongs. I will return to this in the next chapter, where we discuss the role of the certain subjectivities in this referral.

\section{E. The Private inheres in Bodily Comportment}

An alignment can be made not simply with the mere and prior facticity of the body and the fundamental "the private self", but a certain mode of that body, its intentional comportment, its projects. "It is the ordinary purposive orientation of the body as a whole toward things and its environment which initially defines the relation of a subject to its world." ${ }^{36}$ It is the teleological performances of the body, as comportment, Press, 1962:54. 
which organizes the boundary of the non-self world, its object, its limits of "public" space. The boundary of private/public is produced, rather than encountered. And is produced in a mutually conditioning relation between the self and its surroundings. Public space or private space, or more specifically, the experiences of spatiality, inner or outer, "are generated from modalities of comportment". 37

The performative nature of the public/private distinction offers us reprieve from essentialist notions about locations or about the kinds of things and relations which are naturally "found" in those spaces. Variations of comportment might be able to provide the account of the variations in spatial experiences, including my natalist ones.

Feminist work in phenomenology has tended to concentrate on discerning distinct "masculine" and "feminine" modes of comportment (and the sources of these), as a way of accounting for the tendency of men and women not only to take up the public or the private spaces. For example, Iris Young reads spatiality and comportment as a 'specific situation' for women. And, she includes pregnancy as one of those specific situations." Feminist criticism can open up serious gaps in the theories that it believes itself to

Iris Marion Young, "Throwing like a Girl: A Phenomenology of Feminine Body Comportment, Motility, and Spatiality." The Thinking Muse: Feminism and Modern French Philosophy. Eds. Jeffner Allen and Iris Marion Young. Indiana University Press, 1989:55.

38

I. M. Young, "Pregnant Embodiment: Subjectivity and Alienation." The Joumal of Medicine and Philosophy 9 (1984):45-62. 
be extending simply by taking account of gender. ${ }^{39}$ In the case of feminist

phenomenology, accounting for the differences in spatial experiences between men and women, the differences in "availability" of spaces, and styles of physical modalities in those spaces, has required a complexification of the phenomenologist's account of intentionality, subjectivity, and bodily autonomy. When Young links "the oppression of women" to a decrease in the range of possibilities for intentional enactment in space, she is doing two things. First, she is setting up something of the non-Self, the public as that encountered. This suggests that what is external to self has a prior and greater role in the production of subjectivity than that bodily, intentional self. This is at odds with MerleauPonty's description of the body as initial and negotiative. How exactly is it that less space "belongs" to her, or "is available to her grasp and movement" $?^{40}$ What is it that "radically undermines her projects"? In the first half of "Pregnant Embodiment", Young explores how the body itself, in a state of pregnancy as a novel matrix of intentionality and world, actively reorganizes what it previously took as Self and non-Self. But in the second half of the paper, she has shifted her attention to the public ways in which the female pregnant body is delimited from without. She focuses on the external motivations which those same women appropriate in order to direct their movements as pregnant women in Feminism." Women and Revolution. Ed. Lydia Sargent. Boston: South End Press, I981; It is also true of Feminist Empiricism. See Marcia Millman and Rosabeth Moss Kanter, "Introduction to Another Voice." Feminism and Methodology. Ed. Sandra Harding. Indiana University Press, 1987:29-36.

40

$$
\text { Young (1989:63). }
$$


accordance with public pressures on women as pregnant. Although the phenomenology of mutual conditioning is retained, the active intentionality of the female body is now given over to reactive responsiveness to something standing outside of it. In other words, the static, repressive view of power which phenomenology is trying to replace by its story of the on-going intentional constitution of the Self, reappears in the gendered body as that which prevents that intentionality from being expressed. If Young's account is accurate, it suggests a specific, limited agency for women as pregnant embodied beings. That the specificity of pregnancy as a gendered bodily comportment seems to cause phenomenology to shift underfoot suggests that while it maintains that both male and female bodies are historical constructions - for our purposes that they stand in equal capacity to take up and organize relations of private or public - it might also be committed to the view that the female body in particular comportments is a natural "fact" or "species"." This puts the public/private out of performance or active comportment and into the next possibility, a "distinct sets of activities".

If we accept Young's account of the dynamics of the construction of a private self in a particular embodiment, then we accept an ontology of power as repressive. This effectively covers over the complicity of women in intentionally directing those experiences of contraction, relegation and confinement. At the end of this chapter, I will revisit this idea of the active complicity in containment as private beings (bodily or Ponty's Phenomenology of Perception." The Thinking Muse. Eds. Jeffner Allen and Iris Marion Young. Indiana University Press, 1989:85-100. 
socioculturally).

Finally, since some versions of the phenomenologists' story of intentionality as positivity (autonomy as doing, being, stating), it cannot render as a kind of agency intentionalities which cultivate privations (having done to, erasure, silence, self-confinement). ${ }^{42}$ Where are we then, and what are we, when our bodily intentionality and bodily autonomy is in flux? When we lack projects, or when something of Self and non-Self is simultaneously organizing our bodily realities? Pregnancy, as experienced bodily, is just such a moebius strip:

Nor, in pregnancy, did I experience the embryo as decisively internal...but rather, as something inside of me, yet becoming hourly and daily more separate, on its way to becoming separate from me and of-itself. In early pregnancy the stirring of the fetus felt like ghostly tremors of my own body, later like the movements of being imprisoned in me; but both sensations were $m y$ sensations, contributing to my own sense of physical and psychic space. ${ }^{43}$

In the absence of bodily autonomy are we nothing more than "geometric dead space where all positions are external and interchangeable"?+4 The poles of "bodily self" and "non-self" which phenomenology uses to distinguish private from public are not

Bordo's "The Body and the Reproduction of Femininity"explicitly takes up a Foucauldian account of power, i.e. starts by refusing to account for women's oppression by a story of power which sets women outside the possibility of their central collusion, yet still slips back into the language of repression, such as when she states, "the public space which women are allowed to take up is circumscribed, limited" (1989:18) emphasis added.

43

Adrienne Rich. Of Woman Born. New York: W.W. Norton, 1986:63.

44

Young (1989:63). 
independent positivities external to one another, not "acting" and "acting upon", but a kind of on-going relation of variegated aims which use the body as a key surface of enactment. There is possibly no more variegated bodily surface than a pregnant female. Onto this, endless ambivalence and debate can be foisted: "the abortion debate" will never be solved. The body, again, isn't strictly the separate source of these.

\section{F. The Public and the Private Cannot be Distinguished according to Distinct Sets of Activities.}

Consider then, as our third attempt to locate the private in the body, the less esoteric claim that certain activities of the body are, by nature, private. That is, bodily behaviors or activities classify the public or the private. With regard to the private, what activities are we speaking of? Nudity, thought, sexuality and rituals of hygiene. Do these enact the nature of "the private"? With regard to the public, what exemplary activities are we speaking of? Contractual agreements (especially buying and selling), voting, making and what is called work. How do these different activities map onto femininity and natality?

The more stringent demands for public modesty from females and gay couples, in addition to the extraordinary historical and cultural ranges of acceptability on public nudity, practices of hygiene, and sexuality, should alert us to the fact that we can not speak of all bodies, all of the time, but only about the way certain bodies and their activities establish relationships -- habits -- in networks of power. Some of those relationships are so habituated that they appear as if natural and universal. One example in our present North American culture is breast-feeding. Breast-feeding involves three of 
the allegedly private activities: there is some nudity, there is some sexuality, and it is a ritual of hygiene. In my own experience it also involved thinking about what was happening. There is, unsurprisingly, a scarcity of breast-feeding positive and supportive public spaces. Some public spaces specifically identify as breast-feeding positive. The use of these signs highlights the lack of these areas. Even in the obstetrics ward at the Nôtre Dame hospital in Montreal, there was no place where I could easily nurse my children: there was no "private" room set aside for this. There was a chair in the middle of the nursery (among the other babies; that is, among other adults there to be with their newborns), which, as we know, can be viewed through large windows from the hospital corridors. Also, the janitor cleaned the floor around me. It seems that such inhospitality makes breast-feeding only viable in private, rather than an essentially private activity. Breast-feeding, then, and having sexual intercourse, and washing one's hair are neither essentially public nor private activities of the body, but they are construed that way, largely practiced that way, and hence are generally perceived to be that way.

Persistent or consistent perception that these activities are fundamentally private or public does not necessarily give us the truth about the nature of activities. Foucault suggest a wonderful example of perceptual inversion in The Use of Pleasure. It is fairly common to hear people express just such a distinction between early Greek and later Roman culture in terms of the treatment of sexuality as a public (acceptable) or a private (unacceptable) bodily behavior, in this manner: The Greeks, it is said, were highly tolerant of public expressions of sexuality, while the Romans (and Early Christians) were 
increasingly intolerant of it. Yet Foucault provocatively asserts that precisely the opposite was true, at least if the relative quantities of extant literature can be used as an indicator. Foucault claims that Greek sources are notable for a general absence of the "long lists of possible acts...the manuals of confession...the tables that served to define what was licit, permitted, or normal, and to describe the vast family of prohibited gestures." ${ }^{45}$ The writings displayed a remarkable reserve, unlike the Christian texts, which lavishly and extensively did supply just those descriptions, classifications, deep regimens, etc. The perception, then, that Christianity demands the confinement of sexuality to the private, is countered by the fact that Christianity discussed sexuality, in public, at great length and in great erotic detail. This suggests that the activities of the body can occupy both realms; however, the same acts of the body can be received or rejected, displayed or relegated, rejected or approved of, as appropriate or inappropriate to those spaces. How these line up will depend again on a wider set of power relations which "catches the body up in them" including the power or perceptions and the authority to invert status. Individuals are readily able to, and are obliged to see themselves as having the status of private or public individuals while performing activities which provoke either a public or a private-inflected response.

For instance, if a strong candidate for why a birth must take place in the hospital is that there the bodies of the mother and the newborn will be handled with better hygiene York: Vintage, 1990b:38. 
practices than if this happened in the home, then why does this same argument concerning the practices of the body and the best space to carry them out not also show up in support of having children in licensed daycare centers? Of course we all cite the potential contact with other children's germs, and the high incidence of second-hand infections, but notice that these are exactly the same kinds of risks one would encounter in the hospital...

Irregular responses to, and relegation of activities to the private or the public suggests that these are gendered, though again not in a perfectly consistent manner. While, on the one hand, under the scheme long and widely endorsed, "that women must be excluded from the public realm...because they are the caretakers of the body", ${ }^{46}$ a superabundance of female pornography and strip-clubs the world over illustrate that female public nudity is more exempt than any other kind of body from the rhetoric of relegation to the private..$^{47}$

Even without these examples of activities which can and might take place in public were the public more hospitable, and activities which might take place in private were the public less hospitable, any claims of the activities of nudity and sexuality being

Iris Marion Young, "Impartiality and the Civic Public: Some Implications of Feminist Critiques of Moral and Political Theory." Feminism: The Public and the Private. Ed. Joan Landes. Oxford: Oxford University Press, 1998:432.

47

For a complementary study of the inability of the public/private distinction to locate the center of offense of public nudity, that is, to censor precisely what is said to need censoring, see my, "Antiporn Cons and Pros: How Long is the Arm of the Law?" International Studies in Philosophy XXX/I (1998):79-90. 
essentially private lead us back to the home, to the bedroom. I have already denied that this as a space which can be defined independent of the public.

Was my relegation to the home during the course of my visible pregnancy a response to the way in which the fact of my being a sexually active female was too clearly signified in public during those months? It wasn't having intercourse in the street but might as well have been? Oppositely, I could as easily posit that being so large and shapeless, I "was not looked upon as sexually active or desirable", + or, being so obviously already "taken", was temporarily exempted from public exposure. Perhaps sexuality and nudity are really among the essential, foundational activities ${ }^{s t}$ of the "public" sphere?

My experiences with respect to the activities of my body and the correlate prescriptives they drew were anything but clear and unambiguous in natality. I would expect that across class, race and age, there would be equally complex mixes. The mandatory pre-natal visits to the physician are at cross-purposes to the underlying belief that women, in the home, are the appropriate caretakers of bodies. These visits were certainly de-sexualized, exhibiting an "aloof matter of factness", possibly, as Young

$$
\text { Young (1984:52). }
$$

Here, I am thinking of Carole Pateman's "The Fraternal Social Contract", where she traces Freud's myth of the inaugural violence of civil society not as a moment of economic necessity, but as a moment where the formation of a certain framework of sociability guaranteed sex for the men - "the primal horde" --who had made the original contract (The Disorder of Women. Stanford, Conn.: Stanford University Press, 1989:33-57). 
suggests, "in order to preclude attaching sexual meaning to them".so This would be consistent with the original schemata which designates intimacy as private. On the other hand consider that a regular occurrence during my months as a visibly pregnant woman was of being touched on the abdomen by complete strangers. Or, if not strangers, friends who never before had impulsively touched me. I consider this intimate, non-consensual behaviour. Are these touches not a common occurrence with children, the elderly and the physically disabled? Such a diverse group suggests that such intimacies have nothing to do with the activities of those bodies and everything to do with the status accorded to those persons, as either persons or as objects.

If the body itself is the primary inviolable privacy domain then what account can we give for treating different bodies with different degrees of proprietary respect? Isn't privacy itself "about certain activities of bodies" only about only some bodies, some of the time, under some conditions? Natality, then, is a kind of context according to which a range of activities can be classified as either private or public.

\section{G. Are There Essentially Public Activities?}

I would like now to consider a set activities which are taken to distinguish what is essentially public from what is essentially private: commerce. The connection between property and this section becomes evident here. This will lead us into our next section on potlatching cultures where we will examine the ways that activities of property, too, are

Young (1984:58). 
classified according to context.

All allegedly "public" activities of the body might be said to involve a certain genus of exchange - commerce -- initiated between natural or artificial individuals, such as the exchange of labor and money between me (Karen Houle) and my employer (Mount Allison University). These exchanges involve one or more of the following: labor, work, rights, debt, money, power, promissary notes, oaths, rules, skills, votes, licences, commodities, products, property, utility, services. Public transactions involving one or more of these are the reciprocal, (relatively) immediate, mutual expressions of autonomous abstract individuals. They are undergirded by legal enforceability. They map onto Locke's notion of political power.

Certainly, not all exchanges are public matters. In the private realm there are also kinds of transfers, but these are said to be essentially different, to involve different subjects, objects and above all, intentions. Private "exchanges", by contrast, might involve: gifts, promises, labors of love, sex, children, heirlooms, vows, energy, affections, support, belonging, care, well-being, hospitality, names. Elements of private exchanges are said to satisfy the "higher needs" of our personhood, to engage some primary part of what it means to be a human being. ${ }^{\text {si }}$ Public exchanges are general

That the private is fundamental in this respect is not universally held. Aristotle is a good candidate for the opposing view, that distinctly human forms of excellence are practices of public or civic virtue. "Public life -the life of the citizen, the possibilities of friendship between equals, the attainment of virtue, the experiences of freedom, including contemplative freedom...." constitute the essential and best aspects of what it means to be distinct, as human. In Aristotle we learn that the terms of the private bind us to necessity and utility; that is, to the reproduction of species, to the needs of the body, therefore in private function we are not set apart from nature and animals. See Nicomachean Ethics 1 142a25, $1178 \mathrm{a} 6 \mathrm{ff}$ and Book VII:131 I 53b(end); Politics 1333a30ff, 1332b32; De Anima II.4 415a26-b7. We could ask whether "thinking", which presumably can take place in the private realm, is free from necessity? Aristotle answers in Book $X$ of the Nicomachean Ethics that the life of highest happiness is the 
whereas private ones are specific. Where they occur, private exchanges are undergirded by custom or morality rather than economics or legality: there may be family pressure to contribute to a baby shower but it isn't anyone's right to receive a present.

The nature and content of private exchange are taken to be ontologically distinct from the nature and content of public exchange. The contents of private exchange are said to be "beyond price"s2 and "inalienable". They differ from public exchanges because they "are transfers....without exploitation,.3 or compensation."st This is how "gift" is distinguished as a category of activity. If reciprocity of, say, affection, happens to show itself in this realm, we say that it isn't required to be immediate and is not the intended

contemplative life, a life of philosophy. However, this life is only possible through virtue; and the Aristotelian virtues - justice, moderation, wisdom - are habits of the civic rather than the domestic realm. (The Basic Works of Aristotle. Ed. Richard McKeon. New York: Random House, 1941).

52

Henry Hansmann, "The Economics and Ethics of Markets for Human Organs." Journal of Health Politics, Policy and Law 14 (1989):57-85.

53

Stephen Munzer. A Theory of Property. Cambridge: Cambridge University Press, 1990.

54

Mordechai Kurtz, "Altruistic Equilibrium." Economic Progress, Private Values and Public Policy. Eds. B. Balassa, R. Nelson. New York: North-Holland, 1977:177. The distinction between altruism and "self-serving" behaviour is not that an exchange is necessarily non-reciprocal, but rather that reciprocity is not expected or intended in an act of kindness, even though it may be returned. Clearly, there is no way to prove what the mental state of the giver was at the time of giving. Evolutionary biologists can use this, in conjunction with the theory that the gene is the central unit of the human, not his or her macrosocial reality, to claim (tautologically) that all altruism is only self-interest in disguise. If all people can only ever be egoistic, then biologists can make no sustainable, substantive distinction between public and private exchange. See The Challenge of Humanistic Economics. Eds Lutz and Lux. Menlo Park: Benjamin Cummings, 1970. 
motive.ss. To make a return in kind on gift or friendship the object of one's gift-giving or friendliness violates the Kantian maxim that persons should never be treated merely as means but always as ends-in-themselves. To pay for labors of love is seen as base, crass or insulting. ${ }^{56}$ To refuse payment, or to refuse to entertain the idea of payment, for labors which otherwise can be and are paid for (sex, childbirth and rearing, housework) combines the ideals of femininity and love, and in this, a line is formed between public and private activity. Where, in private life, we find some kind of reciprocal venture, it registers as "support" rather than "economy"; indeed, such exemplary private support is prescribed in Locke's conception of parental power. If and when "private agreements" are legally enforceable -- such as in the case of the duties of parents regarding the raising of children or the transfer of children (adoption) -- we find that these are also coded as if public contracts, in this case, between the parents and the State on behalf of the parties called children. ${ }^{57}$ Finally, where we find regulation of these kinds of extensions of the private into the public, it is mostly the province of non-profit agencies.

Can we use this distinction between the kinds of exchanges which are, by nature,

David A. Collard, "Blood and the Gift Relationship." Altruism and Economy. Oxford: Martin Robertson \& Co., 1978:140-150.

56

Elizabeth S. Anderson, "Is Women's Labor a Commodity?" Philosophy and Public Affairs 19:1 (1990):71-92; See also Phyllis Chesler's The Sacred Bond: Motherhood under Siege. London: Virago Press, 1988 for a pro-maternalist attempt to rescue the "sacredness" of mothering from the corruption of economics. 
private or public, to understand my maternal narrative? Evidently, the acts of having a baby, of becoming and being a mother, is the quintessential private activity -- the labour of love; the gift -- the gift of life. There is, for many, the strongest of opinions that it is intrinsically evil to make a commodity out of life, and out of those things essential for life: blood, air, health, ova \& sperm, a next generation.ss ${ }^{. s}$ The persons involved (baby, Mom, Dad, women or men, society), the claim goes, can only be harmed, cheapened and coarsened by commercial influence, even when and where these sorts of contacts increase other heralded values, like personal autonomy. This is forcefully and beautifully expressed by Marx.

If money is the bond that binds me to human life, that binds society to me and me to nature and men, is not money the bond of all bonds? Can it not tie and untie all bonds? Is it not, therefore, also the universal means of separation...it changes fidelity into infidelity, love into hate, hate into love.....s9

This view about distinct ontological categories of what is human and what inhuman (property or commodity) appears as one of the central arguments against surrogate motherhood arrangements:

Commercial surrogacy attempts to transform what is specifically women's labour - the work of bringing forth children into the world - into a commodity. It does so by replacing the parental norms which usually

Peter Singer, "Freedoms and Utilities in the Distribution of Health Care." Markets and Morals. Ed. G.A. Dworkin. Washington: Hemisphere, 1977. Singer does not take this view.

59

Karl Marx, "The Economic and Philosophical Manuscripts of 1844." Karl Marx: Selected Writings. Ed. David McLellan. Oxford: Oxford University Press, 1977:110-111. 
govern the practice of gestating children with the economic norms which govern ordinary production processes. The application of commercial norms to women's labor reduces surrogate mothers from persons worthy of respect and consideration to objects of mere use..$^{\circ 0}$

Clearly, what is private versus what is public flows from this prior distinction about the nature of activities. As this quotation suggests, it is not a matter of the optimal mix of economic and loving motives, but their sheer presence of absence, which qualifies and partitions our basic experiences into two distinct human realms of activity: the private or the public. In my natalist narrative, my association with the private sphere before and after birth, and the exception of the birth itself in the hospital, is nothing other than the story of a predominantly non-commercial (non-public) activity punctuated by another kind of exchange - the payment to a professional for the specialized services of laying in. Mothers epitomize the private self, the selfless self of love. Seeking the services of a skilled professional - and hence birthing in public - is a part of that love, rather than something foreign to it. Mothers who have and provide child-rearing capacities but who take money for these labors do not define the ideal, either of womanhood or of the private realm. Dr. Benjamin Spock, probably the most influential American pediatrician, provides this advice to "working Moms":

...the mother may decide to leave him in a foster daycare, that is to say, in the care of a woman who makes a profession of caring for children. But the foster mother should be doing it because she loves children rather than 
for the income it brings. ${ }^{61}$

\section{Speculations:}

The division of the public and the private along the money/love split, again, does not so much reflect some deeper truth about what is fundamentally one kind of thing or another entirely different kind of thing, so much as it reflects a set of values which can be displayed as true via this split. Those ideals - hygiene, romantic love, autonomy, masculinity, dignity -- are not always of benefit to those who are expected to display them in one sphere or another. This theory of separate spheres, and particularly that one is the natural domain of man or of woman, "emphasized the complementary nature of men's and women's roles...glossing over their inequality."62 There are good arguments and good mechanisms for bringing public economies into the private realm as a means of remedying this inequality: the wages for housework campaign is one example, paid maternity and paternity leave is another. Susan Okin suggests a leveling method by which both the non-waged stay-at-home care giver and the waged worker have equal access to earnings. Under the account of the nature of the private that I have just sketched, women, by virtue of exercising their capacities as reproducers, caretakers, (non-paid, nonrecognized laborers) in the private sphere, opt out of their capacity to enter political

Benjamin Spock. The Common Sense Book of Baby and Child Care. Simon \& Schuster, 1945:54.

Patricia S. Mann. Micropolitics: Agency in a Postfeminist Era. Minneapolis: University of Minnesota 
association as free, equal rational individuals "capable of owning property". ${ }^{3}$ If the conditions of, and gains afforded through political association lie in one's relationship to commerce, then women will never achieve overall equality. Related to this, feminists have argued that uncoupling reproduction from the strictly private, such as artificial insemination or surrogate motherhood arrangements, are "'not inherently dehumanizing' and might be part of the solution to women's oppression within the patriarchal family." The public/private so conceived, is clearly a political, rather than (or maybe in addition to) a natural matter. Specifically, these feminists suggest that in a just society, this distinction would not exist.

Examples from outside white, middle-class, liberal culture highlight that sketching the public/private distinction in this way, and rallying a particular vision of those values behind it are the prerogative of a vantage point. "In most of the world's poorest regions, sex is bartered as easily and with nearly as little moral stigma as bananas." "Bs But, even "within" North American culture, the private and the public are not even as separate as we might pretend or wish. Or, that we ourselves blend love and commerce depending upon what purposes the ratios serve. The increasing addition of "prenuptial agreements" to marriage vows paints just such a picture. "Increasingly,

Locke (Ch. I:sec 65).

64

Mann (1994:1 12-1 13). Mann is quoting Shulamith Firestone, The Dialectic of Sex. New York: Bantam, 1970:199.

65

Francisco Goldman. Bookforum 7:1 (Spring 2000):33. 
marriage itself is being recast as another budget item in everyone's personal finance portfolio."66 Hitt notes that all things allegedly good and true and human in this world marriage, healthcare, education and Church - are increasingly operating under, or described in, market terms. Hitt also reminds us that the institution of marriage qua public institution is an historically-bound, state-sanctioned legal, rather than private entity. This makes the current trend toward prenuptial agreements a reversion to preCouncil of Trent terms, rather than a novel progression.

It is not the case that certain kinds of public activities are, by nature, public and therefore are able to define a separate sphere in this. It is the uptake and application of these two sets of activities which does the work of dividing off, as if separate and distinct, what is private from what is public. There are specific historical and political relations between the appearance of the phenomena (publicity or privacy), and the kinds of forces responsible for their appearance as habitual patterns. In this section I have attempted to destabilize the presumed naturalness or foundations of the public and private distinction, and to superimpose this destabilization against an experiential narrative within which the public and private played complex roles. This first section, then, is intended to provoke questions about how the patterns of public and private become established and naturalized, and, whether or not these patterns serve the interests of persons directly implicated in them? In the next section I am going to depart from my natalist narrative to preserve its distinct, non-commercial essence Hitts shifts the center of a marriage bond from the vows to the emotional state of being in love. 
(though I will return to it at the end of this chapter) and look more directly at how patterns of property connect up, historically, with this naturalized public/private distinction. I do this by looking at potlatch economies and their encounters with capitalist economies. As an analogue to my own "confinement" as a pregnant female, I hope to illustrate how quite different, yet equally complex, life-giving activities become confined to the private domain under a specific set of conditions. These sets of conditions or forces organize the discursive field of property: they divide individuals from the group, they divide women from men, they relegate women to the private sphere, and relegate men and property to the public, and they moralize/criminalize any activity which does not fall into line with these divisions. This division takes place via many forces at many levels over an historical frame. Genealogical analysis requires that we pay close attention to these historical details. A longitudinal look at potlatching, then, will further undermine the claim that public space is, by nature, the realm of property and commerce. It will further reveal that property is discursively formed through discernible microforces at work to divide and confine. We will discover that potlatch, while avoiding the public/private relation, does not entirely avoid the inequality problems. This fact underscores that we can't say definitively that potlatch is a better model for property or a worse one, but that we must look at the kinds of relations working to create and sustain these practices, and to say something about who and what these relations are in the interests of. In the final section of this chapter, I will take one of these "microforces"the creation of specific subjects of authority - back to the natalist narrative, in light of a 
larger framework of power relations, to discuss whether natalist authority is in the interests of women.

\section{Part Two: The Potlatch Series}

There is perhaps no better socioeconomic counter-example to late 20th-century capitalism's "global society", with its division of private gift-giving versus public commodity-trading, than the potlatching societies of the Pacific North West which James Cook (1778) and George Vancouver (1792) encountered at the end of the 18 th century:67 the Kwakiutl, the Haida, the Tsimshiam, Tlingit, the Coast Salish, the Nootka, and the Bella Coola. While each of these language-based Nations practiced elaborate variants of potlatching, and, while among anthropologists, there are competing theories regarding the ultimate function of the potlatch, the ethos and motives of potlatching cultures, the terms and units of exchange, and even the characteristics of those individuals who practiced potlatching; these nonetheless all qualify as "total social fact" type economies after that described by Marcel Mauss ${ }^{68}$.

What Mauss meant by this is that all aspects of a nation, however they appear as "public", "private" or "social" function (marriage, survival, sex, war, religion, humour,

Even the practices of trading, ceremonies and mobility which anthropologists recorded may already have been re-organized in relation to European contact; in other words, that what we came to know about these cultures, via these anthropologists, as a "counter-example" might have been even more pronouncedly different than what was the case prior to contact. Smith (1999:86) alludes to the debate as to whether the pattern of settling in winter villages, where most of the ritual ceremonial events were held, may have been a post-contact effect.

68

Marcel Mauss. The Gift: The Form and Reason for Exchange in Archaic Societies, Trans. W.D. Halls. New York: Norton, 1990. 
activities, theatre, property of all manner, crafts, status, myths, education), all are threaded through a single overriding mechanism, the potlatch. Every single member of a nation (tribes, families, and individuals) has a vested interest in the potlatch, and each physically participates in these ceremonies, since the outcome of the ceremony will have some bearing on him or her. This is true of those individuals with or desiring a name and rank (a "seat"), members of family-groupings (numayam) with names and rank, and larger ritual congregation, which exchanges name, rank and wealth. These persons do not hold their "seat" from the moment of birth to death, but receive a rank from one who gives it up entirely, at a succession ceremony. This interest is also true of "commoners", or those members of tribes without name or rank, since they still exist in relations of mutuality and usefulness with the chief and his grouping, and are potential if not preferred name-takers. ${ }^{69}$

All rights, duties, and privileges flow from title, though title does not flow unidirectionally, as we saw with the patriarchalism Filmer defended. It is status which is potlatched. Status is the scarcity condition. ${ }^{70}$ Rank and name are what could be called ones "property" rather than ones mere possession in land, things or even people. These latter are what is "given" and enacted in potlatch in order to gain or maintain the prestige and rights to a name, rights which arise from and are confirmed in a ritualized generosity.

Eric Wolf. Envisioning Power. Berkeley: University of California Press, 1999:93-95. 
Potlatch is a true and full form of social contract: all members of society are contractors with all other members. Moreoever, these ritualized exchanges mimic a structure of rights and obligations which is considered to have been negotiated between the world and the humans who occupy it; between the human and the spirit chiefs. In exchange for the gifts the ancestral beings bestowed upon humans, including a claim to an ancestral heritage based in the earth, the chief must model and continuously enact, among and across tribes, this fundamental all-embracing compact." It is an economy of and for all these members, and all possible exchanges between them. It is,

...an economy many stages removed from ordinary subsistence activities, an elaborate hierarchy of social positions possessing scarcity value, and the development of so complex a scheme of credit, investment and interest that it is accurately descriptive to term it "finance"."n

"Potlatch" means "to flatten". ${ }^{3}$ Chiefs flatten each other (therefore their people flatten others) with gifts, as responses to eternal and local challenges to name and rank. Potlatching also occurs not in direct reaction to property threats or gains but as a spectacle in celebrations of girls' menses, of marriage, of death, of the completion of projects. Status is asserted, transferred and reasserted continually through accumulation, ${ }^{74}$

Wolf (1999:90).

72

(ibid:80).

73

(ibid:68).

74

One often heard contemptuous evaluation of the Kwakiutl was that they were lazy, lacking in industriousness, regularity, and the basic requirements for civilized social function: a desire for, and strategies for accumulation. (Halladay, 1890 Annual Report, Canadian Indian Affairs). Codere (1950) corrects this view. Clearly, 
debt and credit arrangements, followed by excessive, calculated "gifts" and their spectacle of giving. It is like giving away a present with the price-tag on, where everyone sees both the giving and the price tag. Chiefs even go so far as to destroy their own villages' most valuable property in front of the collective. These items do not "belong" to him, nor to the members of the community. They are means to gaining and maintaining the things which can be said to properly belong to them, their rank. Because of his rank, both as an individual and as the representative of a group with a relative ranking among groups, his gestures are gestures on their behalf, and initiate the mechanism of potlatch in which they stand to gain or lose rank. When a chief gives his name in a succession ceremony, he does not remain an old royal hand-waver: his rank disavows him entirely and he must return to the status of an unnamed; even to the extent of dismantling and giving away the boards of his house, which are also imbued with the same spirit and power which is no longer that persons' prerogative to enjoy. ${ }^{7 s}$

While each of them fights for rank and names at the level of their individual selves (and this shifts), they also are members of a larger whole which fights for rank and name. That the latter - the relative rank and wealth of the numayams - is more stable than the former - the relative rank and wealth of individuals - suggests that individuals likely conceived of themselves first as parts of the group and second, as unique members within

the potlatch was a kind of industry which required a high level of skill, production and accumulation. The Kwakiutl were not idle and lazy; they were fiercely hard-working and extremely well organized. It's simply that, at the level of the individual, they didn't continuously hold onto what they made or gathered, but put it all back into circulation.

75

Smith (1999:92). 
that group. ${ }^{76}$ When a chief, then, destroys everything that the group has, in this they all bear witness to this highest indicator of wealth: the willingness to impoverish oneself.

The potlatch is the ostentatious and dramatic distribution of property by the holder of a fixed, ranked, and named social position, to other position holders. The purpose is to validate the hereditary claims to the position and to live up to it by maintaining its relative glory and rank against the rivalrous claims of others. ${ }^{n}$

Potlatching cultures exhibited those activities which we now take to be the distinct marks of public activity -- "finance" -- yet they did so within a structure of exchange which we generally take to be indicative of the private -- "gifts" and "name-giving". Furthermore, this structure was not separate rituals of life (sex, eating) and death (war, funerals). Potlatch societies seemed to have combined gift and commerce, buying and selling and affective ties under the same function. These same societies seemed to lack a division of public and private (or to have drawn that distinction so differently from our own that we can't readily compare them). "The things which appeared to be most private were in fact the most public". "What is strictly personal, you give away." Because of this breadth and depth of mechanism, Helen Codere denounced Franz Boas' organization of Kwakiutl society into public and private as "nonsense". ${ }^{\text {p }}$

Franz Boas, "The Social Organization and the Secret Societies of the Kwakiutl Indians." Report of the U.S. National Museums for 1895. Washington, D.C. (1897):314.

77

Codere (1950:63).

78

Helen Codere, "The Amicable Side of Kwakiutl Life: The Potlatch and the Play Potlatch." American Anthropologist 58 (April 1956):348. 
The example of potlatching suggests that the public/private distinction (in property, in activities, in kin relations) as we know and practice it, does not pre-date and ground commerce, ${ }^{79}$ but precisely the opposite: that specific forms of power/knowledge drive a public to be distinct from a private, and that those partitioning forms of power/knowledge were moderate or absent from potlatch culture. Gift is not necessarily distinct from non-gift, but similarly, has become stratified as a distinct kind of behavior or thing in post-potlatch type cultures. The commerce/gift distinction is not foundational, but certain sets of behaviors came to be interpreted as belonging to one category or another. This would be true of the anthropologists who observed and named certain behaviors of the potlatching Aborignals as one thing and not another despite the fact that, ...the behavior of two altruists in interaction with one another can look like exchange. A gives to B, and B gives to A. Conversely, what we ordinarily take to be exchange may really be a form of reciprocal giving. There is no logical way to distinguish the two. ${ }^{\text {so }}$

Thus, it is by examining the transition from potlatching societies to modern capitalist society (or the replacement of one by the other) that we can determine the specific historical, economic, political and epistemic forces which caused a public/private split to occur and to prevail. From the point of view of property, the production of private/public meant the relegation of gift (such as the gift of life) to one, and commerce (such as the in "civilization".

One of Mauss' main theses is to disprove the thesis of progress which holds that commerce arrives late 80

Lutz and Lux (1970:81). 
sale of reproductive or sexual services) to another of these zones. In what follows I will try to extract the general features of these forces from the historical details, and highlight what I take to be the changing trends in those forces which patterned and stabilized the public/private division.

\section{Six General Features of Potlatch Economies}

Potlatching does not emerge with capital economy, but is a pre-capitalist form of economy. The history of potlatch economies of this region can be divided into four phases: Pre-Contact, (from the indefinite past until 1792), the Early Contact period beginning with direct contact with Occidental civilization and running until 1849 (when the Hudson's Bay Company established a trading post at Fort Rupert), and the Late Contact period during which there appeared to be an exponential growth in potlatching volume and a correlate growth in anthropological data tracking the system. This period is from 1849-1927 (when the Canadian Indian Act outlawed the potlatch), and the Post-potlatch period, from 1920's to the present." Data on potlatching comes from two types of sources: government reports and anthropological fieldwork. All major early 20th-century anthropologists studied potlatching indigenous societies, beginning with Franz Boas and Hunt, then Levi-Strauss, Malinowski, Levi-Bruhl, Edward Curtis, Margaret Mead, Ruth Benedict, and Helen Codere.

From their various studies, I have extracted six general features which can be

81

This periodization is Stuart Piddocke's, "The Potlatch System of the Southern Kwakiutl: A New Perspective." Environment and Cultural Behaviour. Andrew Vayda, ed. Garden City, N.Y.:Natural History Press, (1969):130-153. 
found in potlatching nations, and which are distinct features from those nations of late-capitalism. I cannot gauge whether these features made potlatching possible, or were the result of it."2 My larger argument is that these general features form a sociocultural field, with a unique structure of power, and within which the public and the private are continuous and indistinct, rather than discontinuous and distinct. As we read through these, it is important to reflect upon how changes in these features, sometimes very desirable ones like the shift from inequality to equality of persons, inaugurated the public/private split with its quite different array of desirable and undesirable features. This is important to keep in mind for two reasons: first, in keeping with my warnings in Chapter One, to ward off simplistic normative or historically progressive evaluations of such shifts; second, to keep us focused on the formal features of power relations underlying such shifts which displays to us something of the conditions of change for the discursive field of property.

1) Elaborate, Comprehensive "Kin" Structure. Potlatching nations were divided and ranked by territory; each territory was home to a politically autonomous identity group (a village headed by a ranked chief bearing a cosmological relation to a founding ancestor). Each group was subdivided into three to seven ranked family groupings, called numayams. These family groupings were enormous (on average fifty persons), occupied a single dwelling and, when traveling, a single canoe. The village itself was a highly 
sociable, co-operative unit: villages potlatched against other villages. Relations within

these numayams were not restricted to exogenous and endogenous kin:

A numayam was not a kinship unit in which members could demonstrate connections through descent or affinity. What gave it definition was succession in the chiefly "status lineage" that bore the name of the founding [animal] ancestor, surrounded by associate groups and segments...as well as commoners of diverse origins. Affiliation with the core lineage was neither exclusively patrilineal nor matrilineal but could be obtained through either parent. ${ }^{3}$

\#2. Inequality. However, no single village, family or individual was ever considered formally equal to anothert. Persons were not equal therefore could only be compared and exchanged on a "roughly-equal status" basis. ${ }^{85}$ The entire social fabric was not only named but ranked in accordance with these rough comparisons. One rule permeated all "total social fact" cultures, and that was that all would be ranked from last to first, and that the first receives first. Forms of justice and commerce followed from this ontology: since not all men count equally (because each bears a unique name, position, crest and set of privileges), the death of one man might need to be answered by the deaths of a

83

Smith, (1999:84).

84

S. Drucker, "Rank, Wealth, and Kinship in North West Coast Society." American Anthropologist 55 (1972):225. The pattern of communal (non-private) ownership here agrees with Engels' (1972:9) claim that "civilized society is founded on the private ownership of property", but contradicts his further claim that "due to the absence of private property there was "complete equality in all spheres of life".

85

Stanley Walens. Feasting with Cannibals: An Essay on Kwakiutl Cosmology. Princeton, N.J.: Princeton University Press, 1981:30. 
hundred. ${ }^{* 6}$ It is because of this strict yet anexact ranking that continuous potlatching was desirable, possible, and necessary.

3) Geography and Fluidity. These nations were distributed along thousands of kilometers of Pacific Rim Rainforest (coast and islands). They were not, strictly speaking, nomadic people (since they did inhabit land locations, at least seasonally), but one might suggest that they were geographically enabled by the aquatic (since the entire villages moved regularly back and forth between one another to potlatch). They were more fluid than they were static.

4) Moderate Climate. The climate of the region afforded the Pacific Rim Nations a stable, superabundant and varied food supply. For survival, they did not need to hoard foodstuffs, nor have a system of careful distribution assuring a common level of need, nor develop agriculture. Nor did they need to trade goods. A relative ease of living allowed them time to develop "higher arts" ${ }^{* 7}$ A generous and varied material base meant that they had time to devote to other activities than subsistence related ones. They were renowned as skilled artisans: carvers and wood workers. Partly this was also thanks to living in an area where magnificent cedars (Thuva gigantica) grew, from which massive canoes,

86

Codere, (1966:98-105).

87

Note the point of contrast with Bettig (1996) who reiterates a common assumption that arts are possible only when and where the "artistic commons" is protected; when and where the creator of art is guaranteed to a security of income from his or her efforts. This example modifies this argument slightly: a basic security (but not necessarily private property as the form of basic security) is conducive to artistic endeavor. 
totems and even longhouses could be fashioned. This abundance also allowed them to participate en masse in potlatch festivals, which we by no means free of ornamentation, dramatic plays, poetry and other frivolities. These festivities themselves assured an even more diverse material base and stable economy. Cultures of excess or adequacy and not scarcity are able to sustain a continuous "public" and "private" since the hoarding of goods (wives, oil, information) is not a necessary strategy for individual survival. 5) Oral/Visual Tradition. These cultures were pre-literate. There is no evidence of writing. This is highly significant to the question of the public and the private since, "the Indian has no system of writing and consequently, to guarantee the transaction, the promise is made in public"., information during social gatherings in the form of speeches, dance, stories, totemic carvings and song. Potlatches were frequent enough and all-embracing enough that the collective memory they relied upon as knowledge was as functionally accurate. All members of all the various families (phatries and numayams) attended all the big potlatches (usually two per year in ten day runs, with many hundreds of smaller ceremonials)." In all cases the granting of a name had to be publically witnessed and legitimized in a distributional event, before invited guests."

There were not only social and economic purposes to attending potlatch, the gain 
or loss of one's own social position, but epistemic functions as well. Knowledge, power and property are tied together here, in unique formal alignment. In potlatch all persons bear collective witness to the gift exchanges so that a common agreement could be held regarding the degree to which a summoning chief had successfully or unsuccessfully potlatched..$^{\circ}$ It is safe to assume that this assessment could be both qualitatively and quantitatively accurate. Codere reminds us that each Indian had much to lose or to gain by the accuracy of the record, therefore the collective memory was very sharp. Although physical violence (warfare, fighting with weapons) were seen as equal means of gaining privilege, eventually potlatching (fighting with property) absorbed the warring function and expanded to express it (dramatically, metaphorically) because in potlatch, "social prestige and rivalry could be more fully expressed and dramatized"91 than it could be in warfare. This is precisely because warring with property included all but did not destroy the participants.

...spectators would act as witnesses to the changes of status thus announced and to whatever other transactions also went on. Such memorable events therefore served the function of marking and validating

90

Derrida's account of the logic of the gift as we know it supports my contention that what occurs under potlatch as "gift" is not related to the ontology of gift as distinct from commerce. According to Derrida, "gift' defies a metaphysics of presence; it inaugurates and operates according to "a radical forgetting", rather than an accurate remembering." As the condition for a gift to be given, this forgetting must be radical not only on the part of the donee but first of all...on the part of the donor. It...must not be kept in memory, retained as...symbolic. For the symbol immediately engages one in restitution... [t]he gift must not even appear or signify, consciously or unconsciously, as gift..."(Jacques Derrida, Given Time: I. Counterfeit Money. Trans. Peggy Kamuf. Chicago: University of Chicago Press, 1992:23).

91

Codere (1966:125). 
changes in social status.92

There are connections between a lack of writing, the necessity of transparent, inclusive transactions, the comparable epistemic value of each individual agent as witness, and the accuracy of the collective record. This suggests a role for the emergence of epistemic inequity - authoritative knowers and therefore also non-knowers- in the bifurcation of a private from a public.

6) Near Equivalencies of Value. Records from Early Contact era indicate that the chief items potlatched were foodstuffs, cedar mats and boxes, slaves, oolichan oil, canoes, wives, and furs. These were "near equivalences". They were also entirely functional: even the "fetish objects" were central to, rather than independent of, circulation. None of these items are, strictly speaking, standard measure. There was no "money". Nor was there a second order item which served as a standard measure, through which all these items could be converted into equivalences. What made these rough equivalences function as a workable base for commercial order was a complex system of rough matching and continuous shuffling. This would be true as much for the items shuffled as for the individuals shuffling. The feature of non-equivalences ensured that the potlatch was a continuous process; that participants could not see their role not as originators or completors of a cycle; "the donor is already a donee, any prestation is always already a with property with Butler's (1995:39) account of the rhetoric of warring for freedom in the Gulf where, where those being "liberated" by the Americans were also the ones killed. 
counterprestation...."93 but as upholders of a continuously decentered system which "even the chiefs did not fully compute or understand." Codere adds another closely related observation:

...the preparations and the potlatches formed together such a continuous process that for the most part no obvious starting point for description or analysis can be found. ${ }^{\text {s }}$

Thus there are connections between the complexity of exchange (objects and persons), the lack of standard of exchange, and the inability to establish final authority or final ends about the process, the fluidity of cultural geography and the surplus of basic material goods, and the inability to instigate a rule of exclusion.

\section{The Arrival of a Parallel Economy}

After 1849 and before the turn of the century, we observe some major changes in the anthropological record. First, the number and volume of potlatches were escalating. This is related to two other important facts. First, the construction of the Hudson Bay Trading Post at Fort Rupert marks the appearance in the area of a "direct, non-traditional source of wealth". The Kwakiutl began trading some goods with the White people, in order to procure goods which they (initially) saw as meeting some basic subsistence Routledge, 1997:115. This challenges Mauss' presupposition of originary giving.

94 Codere (1966:68)..

95 (ibid:71). 
needs in a better way than their traditional goods. These new European-made items were also then coveted as fetish objects. Although there was an array of "European" goods available, one particular item took on a fantastic role of its own in both Indian life, and then, the potlatch economy. That was the Hudson Bay wool blanket. Since an individual Indian was paid by the White man in fixed amounts of money, and since the Indians, not needing money, were always able to convert their payment into fixed numbers of blankets, (or were paid their wages directly in blankets) there developed a new, parallel commodity-based value/exchange system alongside the traditional potlatch system. This new system involved: 1 ) individuals making one-time-only (discontinuous) exchanges with non-kin strangers (buying and selling); 2) individuals trading what they could now consider their own (private property = anything that fell outside of the debt-gift constraints of upcoming potlatch ceremonies, i.e. not public, i.e. surplus); and especially, 3) the introduction of standard units of measure, the blanket. It was not the case that the blankets were exceptionally beautiful ${ }^{\%}$ or even more useful than traditional coverings. Very shortly the two economies stopped running parallel and intersected: the blankets themselves were introduced into the potlatch economy as items which could count both as commodity and as property. The blanket could be given away in accurate numbers, be returned with accuracy, and be destroyed with accuracy. A blanket was, "a

There was, in fact, a prior tradition of weaving and decorating blankets, which these blankets of "coarse broad blue cloth" replaced. 
common, useful standard capable of reduction and accurate basis for comparison." The entire potlatch economy was quickly dominated, at the end of the 19th century, by tallies in blankets. For instance, the number of blankets traded in 1849 was twenty, compared to 33,000 traded in 1936.98

\section{Shifts in the Features of Potlatching Cultures}

What followed from this intersection of economics?

First, the accuracy of measure afforded by a standard of measure decreases the possibility that two individuals will be actually known as unequal, therefore there were larger and more frequent public contest to establish or denounce status. Potlatch is driven by reputation and speculation as much as it is by the exchanges which level these. The sheer volume of blankets available via trade with the Hudson Bay Company, combined with this kind of commodity accuracy increased the scale of each spectacle: the number of blankets traded and destroyed as a pure show of wealth increased geometrically. This accelerates the cycles of potlatching since it is the alternating cycles of credit and debt which keeps the system from collapsing. The blankets stand in for a sizable name, but they also begin to be the kind of thing that has power relations independent of tribal status: capital. The third important change is that exchange of units promotes counting alone, as opposed to quantitative and qualitative evaluation. A tally-stick became the 
means of remembering the transaction decreasing the functional need for amassing witnesses to the spectacle. Plus, it is perhaps more tedious to watch blankets heaped on blankets than the previous array of goods, so interest in witnessing the spectacle may have waned somewhat. Without the rate limiting step which scheduling potlatches in locations and in times which all persons would attend forced on the system, more "sub" potlatches could take place which, while accomplishing some of the tasks of redistribution of wealth and affirmation of rank, did not fulfil the incidental role of creating a total social present.

All of these together culminate in the production of a new role within the system: the key witness, the tally-stick boy. The tally-stick boy was simply the one who counted the exchanges, who represented the size of the threat and the success of the rebuttal, the intentions of each chief, numerically. In this stick and its notches is promoted one individual who holds (literally) the final truth about the success or failure of the ceremony and the means of its verification. The formerly diffuse, continuous and evenly distributed net of power/knowledge relations of the collective is concentrated in an individual role, because now only one person is required to fulfill that role. It is also a role which requires different practical skills than the old role of witness; even different skills than the role of potlatcher. It requires numeracy and marking. Possession relies upon the capacity to mark,

To possess something not by hand by by mark is to universalize the ownership relation beyond physical grasping into a kind of cognitive and institutional representing...the paradigm of property has...shifted from 
occupying plots of land to information processing.9

If this new role of information-bearer occurs within a context where there is a division of labor, then only those who have numeracy and writing skills can occupy this role. ${ }^{100}$

This one single role is a unique knowledge position, and in this, reorganizes the structure of the power relations of that society. A new relation to truth is not merely a new epistemology or a new hermeneutics, but "a structural, instrumental and ontological condition for establishing an individual". ${ }^{101}$ Structural changes, changes of direction or discontinuities, cannot take place without an individuated individual to form a pole around which new relations form.

Second, tribes also started to settle closer and closer to the HBC distribution outlets: they combined non-exogenously as new villages, and (possibly because of this) many began to live in single-family dwellings where previously they had lived in multifamily dwellings known as long-houses. When there is only one family per house, the material which is used to build his house, the things which fill his house, and the select few who live and sleep under one roof, become the "private domain", even the possessions of one man. That there could even be some possession reserved for personal

Jay Lampert, "Locke, Fichte and Hegel on the Right to Property." Hegel and the Tradition. Eds. Michael Baur and John Russon. Toronto: University of Toronto Press, 1997:64.

100

This is a slightly different interpretation of the means by which men have, in general, been promoted to the role of adequate witness, and women, in general, not allowed to play that role than the interpretation Donna Haraway offers in Modest Witness. New York: Routledge, 1997.

101

Foucault, (1990b:89). 
use and kept out of potlatch circulation depends upon the ability to keep things out of general view. What could be made invisible to the rest while still maintaining public debtor/creditor status in the potlatch economy becomes what is "his alone". The private, then, is first a place, an actual physical zone in which a certain kind of general knowledge - public scrutiny - can be excluded. To make "the private", what is needed is a physically individuated place where that private can operate (for the individual to withhold from the collective, or for the collective to exclude from itself) as a zone of exclusion. This historical account shows "the private" as a kind of bud which grows off from previous public cycles of distribution. This inverts Locke's account where private property is the base from which communal and affective ties can then be built.

A real space and a conception of the nature of that space are mutually conditioning. The nature of a space is thus politically or morally inflected depending upon what it can be made to exclude or include. Foucault notes the political ends to which architecture was applied at the end of the 18th century, in Europe, precisely because of the capacity of a spatial reconfiguration to contain or promote any number of political, moral or economic values.

...in the 18 th century one sees the development of reflection upon architecture as a function of the aims and techniques of government of societies. One begins to see a form of political literature that addresses what the order of a society should be, what a city should be, given the requirements of the maintenance of order; given that one should avoid epidemics, avoid revolts, permit a decent and moral family life and so on. 
...And how should houses be built? ${ }^{102}$

The Kwakiutl occupying European-styled housing meant that like the Europeans, those private spaces could now be gauged as a comparable moral domain. What I mean by this is that when different groups "occupy" different kinds of spaces (architecturally, politically, geographically), they can be condemned as opposites, "heathen" or "beastly communists", but they cannot be condemned as lesser beings, as inferior to oneself. When Aboriginals occupied European-type housing the moral judgements of dirty, unkempt, licentious, lazy and disrespectful of property could be brought against them. Changes in patterns of settlement, then, supported changes in patterns of judgment.

Occupation of single family dwellings seems to promise increased individual positive and negative freedoms, especially freedom from being part of the whole at all times. Private space is an invisibility, which, like writing among illiterate persons, grants a level of control and secrecy. However, Foucault has suggested, perhaps paradoxically, that spatial individuation can increase visibility, surveillance and hence intervention; that is, can actually decrease freedom. This point is related to the one above. His famous analysis of Bentham's "Panopticon" makes the case that "privacy" - the private jail cell in which the lone criminal appears to be protected from the masses, and the masses protected from the criminal, the recipients of modern considerations of justice - is really an architectural condition for the exercise of maximum control of that individual. "In the 
first instance, discipline proceeds from the distribution of individuals in space. ${ }^{+103}$ Partly

this control is effected through the agency of the individuals who appropriate or fit

themselves to, the individuated spaces of the private.

Third, many indigenes began to enter into other sorts of "seasonal" work labor relations with the whites they were in contact with, as a way of procuring more blankets and/or more personal items. For women, this labour included (a major source of income during the Yukon Gold Rush) prostitution. ${ }^{104}$ Also: the population of these (and all) Indigenous Nations plummeted. Earliest figures count the size of the Kwakiutl as numbering around 25,000 to 30,000 individuals. The census figures drop to 2,000 by the turn of the century. Codere says that the influx of smallpox, measles and influenza cut the native population in half, typically within a few years of contact with white culture. The record is not perfectly accurate: many men were away fishing much of the time; the system of naming and counting which early census-takers used might not have matched

103

$$
\text { Foucault (1979:141). }
$$

Luce Irigaray ("Women on the Market." The Logic of the Gift, Ed. Alan Shrift. New York: Routledge, 1997:185) claims that there are three roles available for women in an economy of male pleasure (of which specific forms of commerce, like potlatch may or may not be examples): the virgin, the mother and the prostitute. Each of these, she claims, funnel value and exchange from men, to men through a particular possibility of exchange/value/order. The prostitute is valuable because she "serves as a locus of relations -- hidden ones -between men. The woman's body is valuable because it has already been used... the more it has served, the more it is worth." In the case of Indian women and white men, the money that the white men paid the women went to the wornen's husbands. Many Indian women died of cold, hunger and venereal disease, but these were replaced by younger Indian women, who, after earning money for their husbands, also died of cold, hunger and disease. In potlatch economies, women themselves were sometimes property, extending a tradition which was not exclusive to non-European culture. On women as property in Ancient Greece, see Lysias, On the Murder of Eratosthenes. in Lysias and the corpus Lysiacum. Ed. Kenneth Dover. Berkeley, University of California Press, 1968. 
the populations later tallied. It is clear though, that in the span of less than a century thriving, rich cultures were decimated. We know that "White man's diseases" killed off these populations, ${ }^{105}$ but according to what mechanism of penetration, circulation, and recirculation? Obviously a mechanism for this already existed within those cultures. But whites did not participate in potlatches, except as the odd observer. However, the blankets that came from trading with the white man were the very things that bred and carried the smallpox, measles and influenza. And the prostituted women who returned from Victoria with money for their husbands to buy blankets to potlatch, also carried back venereal diseases ("scrofula") which sterilized their husbands.

A radical population decline meant that the status and names which were once the item of scarcity were no longer scarce. In fact, there were relatively more and more "higher positions" available, which meant a much less rigidly stratified society. It was for the first time ever, an upwardly mobile, and an egalitarian-tending society. To distinguish oneself required something more aggressive than participating in an overall social movement: it required marks of individuality which augmented the special status of a name. What was "scarce" or "coveted" were "luxury items" (any other items could be bought directly), and "novelty items" (sadly, cheap gadgets and trinkets). Like many people today, the Natives began to distinguish themselves from others according to the things that they "owned", rather than the names that they held and the correlate portion of liberties and respect they established in relation to the whole, the larger group. Surviving 
natives procured these things, and, like the White settlers around them, kept them for themselves and their families. The private was constituted as a property domain. This changed the meaning of potlatch. The potlatch in the early 20 th century became something more akin to social entertainment, a portion of the social fabric, not its entirety.

Fourth, there is one last critical factor in the shift to of the West Coast tribes to a public/private society. That is the criminalization of potlatching by the Canadian government in 1927. Criminalization of potlatch is just one specific example of the larger juridical practice of binary division into "legal" and "illegal". This first division joins together psychological and moral terms with a legal framework, and makes possible the organization of peoples into the subsequent categories: "humane" and "inhumane", "civilized" and "uncivilized", "lawful" and "lawless". This organization will be carried out by the State but also by population upon themselves. Juridical practice is an effective, "single-stroke"106 means of converting a unity into a binary. It is an example of what Deleuze and Guattari identify as an "exclusive disjunctive synthesis". ${ }^{107}$ In the case of the 15th- to 19th-century interfaces between Indigenous and European cultures the world over, the main the target of juridical conversion was, Massumi. Minneapolis: University of Minnesota Press, 1987:448-450.

107

Deleuze and Guattari, (1983b:9-22). 
...beastly communism....a social order based on networks and kinship centred on affiliation to family groups and tribes as opposed to individual interests.... ${ }^{108}$

This social order of potlatching cultures could be "discontinued", broken into a series of individual interests preceding group interests, through outlawing the communal and offering individual interests as the means to legality, respectability, political and economic enfranchisement; in otherwords, through liberal progress. However, in the absence of "individual interests", (or better, in the absence of the right kind of individual interests) a takeover culture must first create them. Generally speaking, a colonizing culture offers to its protectorate access to a system of rights (property, political representation, recognition and identification) or a system of penalties which can only be applied to individuals. In the case of the potlatch, the application of partitioned penalties was less than successful:

the law was framed in terms of the individual offender, yet the "crime" was one of which a whole people [past and future] was guilty. ${ }^{109}$

One could say that the potlatch was, by definition, an on-going group project. The prosecution of a few individuals, even key individuals like Chiefs did little to break the continuity and critical mass of potlatching. Communal holdings or traditionally total

Eric Pawson, "The Land in Cultural Context. Two New Zealands: Maori and European." Inventing Places: Studies in Cultural Geography. Eds. Fay Gale and Kay Anderson. Cheshire: Halsted Press, $1992: 17$.

109 break the wholeness of the process or generate internally, a critical mass of disapproval. (Codere (1966:87)). 
social practices will be broken into smaller parts, or retained as a whole, depending on the degree to which the gains of conversion to legality/illegality outweigh the costs of non-conformity. There will be a different configuration for each factor. The trend toward individualization using European law depended upon the strength of the Europeans to make delimitations among land, persons and things, and to enforce conformity, as well as the strength of the Aboriginals to take up or resist demarcation, to make their own sets of marks known and respected, to enforce or desire compliance. In the case of the New Zealand Maori, several juridical mechanisms ensured successful individuation. The conformity of Maori individuals within the modern colonizing state required that those individuals first be produced out of the tribal state as individuals. The Treaty of Waitangi was signed in 1840 . One of the conditions of the Treaty was that the Maori were required to register their land with the newly-established land registry office. These lands were held communally, but the registration system only legally acknowledged private (single-family) ownership. The Maori claimants registered as "head of the household", and a failure to designate a single individual land owner resulted in its confiscation. ${ }^{110}$ The entry of the Maori into the system of property, as individuals with the legally-backed right to exclude, as owners rather than mere possessors or transients, was only as individuals. Following this land registration came the massive civil "Maori wars" which justified the further infiltration, division, and distribution of individuals onto smaller and 
smaller units of land." A power/knowledge matrix failed to recognize land already held. It justified confiscation of land unproductively used or that belonging to individuals who had failed to properly register their relation to the land as $1: 1$ (criminal activity: trespassers). Within one century of the signing of this particular treaty, the New Zealand landscape was totally transformed. The Ngai Tahu people lost eighty percent of South Island -- more than thirty-four million hectares. More than forty percent of this land in the fifty year period following the Treaty, was allocated to agriculture, mostly sheep runs. ${ }^{12}$ The second mechanism involved the entry of the Maori into the political system. In 1867 Maori men were given the right to vote. Not unlike the previous example of the Kwakiutl securing jobs and houses, normally, as a question of political theory, we think of this right as a clear gain, if not the quintessential example of modern human political autonomy. Such enlightenment principles "often served more as an ideology of domination than liberation." 113 As we saw in the first chapter, a normative analysis cannot proceed without critically evaluating the way its principles have been installed and effected. There, I suggested that an historical account is one way to see the way these principles "work". The view we get from the Maori story on the matter of "autonomy" is

Eric Pawson, "Order and Freedom: A Cultural Geography of New Zealand. " Southern Approaches: Geography in New Zealand. Eds. P.G. Holland and W.B. Johnston. New Zealand Geographical Society Inc. Christchurch, N.Z., 1987:310.

112

Globe and Mail, Saturday, October 5th, 1996. The Ngai Tahu and the New Zealand Government settled a land claim on this date.

113

Sawicki (1991:21). 
less decisively positive. Pawson explains that the participation of the Maori in the British democratic system had two important results: 1) their allegiance to their own structures of government was disrupted and weakened, and 2) they remained the permanent minority within that adopted political system, and therefore could effect none of the substantive political changes in their collective favor which had enticed them to enter the British system in the first place. It is clear that the movement of some Indigenous peoples into this political system would also serve as ground for judgments that were not strictly political: heathen or civilized, mad and sane, criminals and good Natives. The example of the Maori, too, suggests that subjectivities are not unilaterally imposed or resisted, but are a condition of engaging discourses which are desirable and undesirable.

The success or failure of the movement to integration (which is simultaneously the production of binaries) is, as we know by now, is a much more complex matter than mere rights and violence. It is deeper than either ethics or history, taken separately. It is, as I suggested in the first chapter, about thought. It involves the way that the ontological commitments of one unity fits and combines forces with, or repels and resists, the ontological commitments of another. Mauss' comment supports this:

The stumbling block that these laws and, as we shall also see, Germanic law, came up against, was their inability to isolate and divide up their economic and juridical concepts... [the Melanesians] had no need to do so. In these societies neither the clan nor the family is able to isolate itself or dissociate its actions. Nor are individuals themselves, however influential and aware, capable of understanding that they need to oppose one another and learn how to dissociate their actions from one another. The chief is merged with his clan, and the clan with him. Individuals feel themselves 
acting in only one way. ${ }^{114}$

Making the potlatch illegal did nothing to directly weaken the structure of those exchanges. That the territories were water-based and many indigenes still mobile, meant that officials couldn't always locate the scene of the crime. The introduction of the threat of litigation, combined with the other factors I have discussed, produced an indirect effect, which may have also played a role in fracturing the whole. It joined epistemology and criminality. This indirect effect was another upshot of the possibility of privacy that changes in housing afforded:

There was an increase in smaller potlatches held in individual homes. Spatial limitations meant that not everyone could be privy to each spectacle. In order to preserve the wider, social circulation of information about these smaller exchanges, the Natives began to keep written records of these potlatches. They circulated these. This had two effects. First, not everyone could read and write, so the literate were divided off from the illiterate as knowers. Second, any one of these parlor chits could serve as evidence of illegal activity, and identify specific individuals involved to the R.C.M.P..

In general, however, the law could not be said to have effected a shut down the potlatch. The impotence of Canadian law to isolate "a single guilty party" apparently so frustrated and infuriated the State officials that they changed the scale of "the guilty party" to include all members of a village, and acted on rumors of illegal activity rather 
than on its evidence. In one incident at Fort Rupert:

...authorities...came up in cannon boats, demanded the surrender of all guilty participants, and if no surrender, they leveled the village and canoes."15

Forms of governance, or the imposition of forms of governance, even the form of modern governance of liberalism, " in spite of their historical uniqueness are not quite original...they use and extend mechanisms already present in most societies...to a large extent the devices of our [own] political rationality." 16

The production of a modern, individuated being -- "the individual"-- precedes any gains that can be made or violences that can be deployed in modern culture in modern fashions, in the name of this individual. The classic liberal conception is that there are individuals and (then) there is the State, and between these is a zone of conflict, best configured as a narrow, private-respecting, one. Foucault's alternate account is that this zone is at most, a two-century old technique of power which produces both the State and the kind of individual -- the liberal democratic subject -- which Mill, Locke and others defended against that State.

I don't think we should consider the 'modern state" as an entity which was developed above individuals, ignoring what they are and even their very existence, but on the contrary as a very sophisticated structure, in which individuals can be integrated, under one condition: that this individuality

$$
\text { Codere (1966:114). }
$$

Michel Foucault, "The Subject and Power." Afterward to Michel Foucault: Beyond Structuralism and Hermeneutics, 2 $2^{\text {nd }}$ Edition. Eds. Hubert Dreyfus and Paul Rabinow. Chicago: University of Chicago Press, 1983:209. 
would be shaped in a new form, and submitted to a set of very specific patterns."

This recalls Macpherson's assertion that all property rights are rights of individuals; in other words, no rights or punishment can be enacted before individuals are incorporated as individuals within a greater cultural nexus. In the modern state, this means abstract, equal individuals. This can happen only by marking, distributing and enforcing agreed upon or known units of equivalent value: plots of land, titles, labor contracts, which, in the taking up, recognition, and exchange, makes those individuals known as individuals. The moral and political force of the arguments for private property based in "original acquisition" are not drawn from that act ex nihilo: "nothing about bare possession is morally compelling." Rather, from the recognition granted to an individual by a larger community that his or her special claim of ownership, insofar as it replicates, procedurally and substantively, a general right and its conditions which this whole makes use of.

The moral power of original acquisition is like the moral power in the power to make promises. Making promises are performances which require both an intent and an uptake. Specific communities recognize these; nothing outside of the community will or can recognize these. The community, then, expands its relations as it gives power to property claims." "is

Property rights are inclusive rights, the right to be included in and under a general claim.

117

(ibid:214). Association Annual Conference, Halifax, Nova Scotia, Canada. October 14" 2000. 
This confirms that the continuous or comprehensive, general claim (or space, or identity) precedes the discontinuous and specific claim that can be made by an individual.

\section{Summary of Potlatch Economy Transition: The General Forces of Discursive} Production

The following is a summary of what I understand to have been the specific conditions for the division of one kind of undifferentiated whole (neither public nor private) into a binary (public/private): the transition from Indigenous to Modern political, economic and property patterns. These conditions are not strictly causal or functional, they are "historical descriptions of the conditions which made certain forms of domination possible." They are "the necessary but not sufficient conditions...."

1. Excess of Basic Goods

2. Scarcity of Prestige

3. Non-equivalences (persons/things)

4. Complete circulation

5. No writing

6. Total visibility

7. Public Truth

8. Group Identification

9. Fluidity (geography, event cycle)

10. Group Productivity

11. Contract with Whole
Scarcity of Goods

Excess of Status Equivalence/Standard units Binary Exchange

Writing Invisibility and Visibility Individual Expertise/Authority Individual identity Static/Regular Laboring Individuals Contracts $1: 1$

Sawicki, (1991:24). 
The entry of the Kwakiutl into the European economic system is analogous to the entry and assimilation of many indigenous peoples into the systems of their colonizers. Although each of these transitions work through entirely different sets of local conditions, they are all caught up in complex strategies of power organized predominantly via the principle function of exclusion ${ }^{120}$. In the case of potlatching cultures, the production of the discourse of property as we know it, and its correlates, private property and public property, certainly relied upon the three basic rules of discursive production which Foucault had identified: prohibition, division and rejection, truth and falsity. Each of these general principles works to divide off units from an undifferentiated whole, mark and distribute units in differentiated space, and finally, include or exclude them in those spaces on the basis of adherence to the subjectivities produced by the same processes.

The earlier section of this chapter suggested that we could not investigate the public and the private as distinct, a priori categories (of space, of identity, of experience), but precisely in terms of the species of forces which have been associated with the ability to distinguish between a public and a private. This will include, in the case of anthropologists and in the case of pregnant women, the tendency to perceive and describe our movements in those terms. This analysis fully discloses these categories as political and not natural; that is, the public and the private are related to the different capacities of different kinds of forces - patriarchy, geography, physiology, race, class -

Foucault, (1972):216. 
to draw the line between these realms of experience, and spaces for their enactment as distinct. Politically constituted categories are naturalized as if distinct. Nancy Fraser says, correctly, that "the act of description of the private/public line involves power."

She then goes on to assert that "not everyone stands in the same relation to publicity and privacy; some have more power than others to draw and defend the line." This account of forces is not so much inaccurate as incomplete. Traditional political theories, and traditional theories of emancipation and resistance, including Marxism and Radical Feminism use a non-Foucauldian model of power for their normative framework. This more standard view tends to confine power to the political realm, rather than as spread throughout, conditioning and conditioned by, aesthetic, geographic, psychological, and historical forces, to name a few. I have highlighted in my discussion that epistemic and spatial factors come into play "before" the political is even negotiable. It also posits power as possessed, envisioning it as flowing from a centralized source from top to bottom, and being primarily repressive/prohibitive in is exercise. On these accounts, the forces which drive, for instance, mothers into the private domain or which drive communal property into the private domain, are forces seen to be concentrated around an identified binary, such as the individual and the State, or the male and the female. These determinant categories tell us, in advance of any specific situation, the dominators and the subjects of emancipation.

A genealogy of the public and the private substitutes Foucault's model of power 
for the traditional one. When we look at the historical and normative relations which establish the patterns of inclusion and exclusion known as the public and the private as their result, we discover two main things: 1) that forces are multiple and include many more facets than the conscious purposes that already identified political subjects or subject-types pursue, ${ }^{122}$ and; 2) that the relations which establish conditions for a division into public and private, and the relations of domination which ensue are not, strictly speaking, coercive or prohibitive, but include many positive incitements - psychological, social, economic - which those directly dominated take up as strategies.

My analysis of transition from Potlatch to Post-Potlatch societies generated a list of the kinds of conditions which are conducive to non-binarization, and the kinds of conditions which, when present, are conducive to binarization. A culture which is relatively static, and organizes its population in single-family dwellings, for instance, will be a culture within which "privacy" has more currency than a nomadic culture which organizes itself in multi-family dwellings. Writing itself is a kind of private field; it divides a public from a private because it forms an access limit, both in terms of how many persons can, and also who is skilled to, at a given time, access what is written. "The Public" or the "Private" are a patterned actualization of a set of forces which condition the distinction and tend to identify behaviors, things, persons and spaces as native to one or the other. 90) in "Foucault on Freedom and Truth" in Foucault: A Critical Reader. Ed. David Couzens Hoy. Oxford: Basil Blackwell, 1996:69-102. 
In the cases of the Kwakiult or the Maori under colonialization, it is tempting to make the evaluation of victims and victors such as a liberal account supports. However, I hope that I have shown in these examples, that even if such an account were retrospectively true at a high level of generalization (race or class for example), it would not have been an adequate account of the multiplicity and ambiguity of forces that were in play entering and throughout the historical period discussed. Moreover, it would not give space to an account of Aboriginal agency, however that agency expressed itself. Finally, it would override, as morally and politically insignificant, the ways in which individual Aboriginals and Europeans may or may not have been working toward or against the overall ends of discontinuity that came about. To gauge historical and political changes - emancipation and revolution -- strictly according to whether certain overall ends were achieved or not, would be to place an artificial end point within a continuous process. This approach ignores the ways in which individuals' lives can be better or worse according to the kinds of non-general micro-becomings (i.e. not insofar as they identify with a macro category such as "women") that they themselves achieve and live out across any given period. ${ }^{123}$ Micro-becomings are less a matter of an overall model of property that one finds oneself within than the subjectivities that one occupies there.

123

Deleuze Negotiations. Trans. Martin Joughin. New York: Columbia University Press, 1995:171) attributes the ubiquitous sense of shame (not having tried hard enough) and failure (not having succeeded) he finds among political activists and in political histories to the (in his view) misguided intellectual privileging of a final end of things, a state of emancipation (Being) over an on-going, specific series of changes (Becoming). He writes, "They say revolutions turn out badly. But they're constantly confusing tow different things, the way revolutions turn out historically and people's revolutionary becoming...Men's only hope lies in a revolutionary becoming: the only way of casting off their shame or responding to what is intolerable." 
The Knowledge Condition: Subjectivity and Authority

We should abandon a whole tradition that allows us to imagine that knowledge can exist only where the power relations are suspended and that knowledge can develop only outside its injunctions, its demands, and its interests. .. We should admit that power produces knowledge (and not simply by encouraging it because it serves power or by applying it because it is useful); that power and knowledge directly imply one another; that there is no power relation without the correlative constitution of a field of knowledge, nor any knowledge that does not presuppose and constitute at the same time power relations. These power relations are to be analyzed, therefore, not on the basis of a subject of knowledge who is or is not free in relation to the power system, but, on the contrary, the subject who knows.... ${ }^{24}$

In this section, I will concentrate on one of the transitions listed in the table on page 173: the shift from generalized to specialized knowing subjects.

There are two active dimensions to the working of power/knowledge. One is the will to power. The other is the will to truth. Domains of activity and the normative frameworks for analyzing these are co-emergent and co-defining. Something which can be effected runs alongside something which can be known. Power/knowledge produces groups of regularities which are made up of neither the knowledge of a single individual, nor institutional knowledge, nor the will of a single individual nor the will of an institution. Knowledge as power relations is something exercised, and these are exercised, as Foucault says, from below. That is, the mesh of discourse is produced as it is enacted. Individual persons turn out to be one kind of surface on which power relations can be enacted. Many "techniques" of power are capable of inflecting subjectivity in many different nodal positions. 
Foucault insisted that domains must be checked for the specific ways in which subjectivities worked to install and extend those domains. The main domains he studied were medicine, sexuality, criminality and psychology. In each of these, Foucault found that subject positions or personae are appropriated by individuals (sometimes as a physical reality, sometimes as a social reality), and performed according to the kinds of characteristics that those kinds of personae generally indicate. This appropriation is rationalized (whether consciously or not) by knowledge which were associated with those subject positions. Each domain has endemic to it, a personae which best embodies/ensouls the truths of that domain. The willingness to adopt these positions, the ability to resist their uptake, is a function of the kind and amount of power relations anyone might reasonably expect to engage from that subject position. Truth and knowledge are then "read" off these positions, or, unrecognized in these positions, ${ }^{125}$ whether or not there is something "innate" to them.

Positions of authority usher in sociopolitical utilities including modes of discipline, exposure, extraction, and confinement. Foucault documented how the rise and expansion of the human sciences in the last three centuries is a result of the authority of doctors, clinicians, criminologists, usurping the prior authority of priests and Kings.

Vicki Schultz, "Women 'Before' the Law: Judicial Stories about Women, Work, and Sex Segregation on the Job." Feminists Theorize the Political. Eds. Judith Butler and Joan Scott. New York: Routledge, 1992:29734. Schultz connects the Lacanian notions of misrecognition and unrecognition to sexual harassment in the workforce. 
These authorities infiltrated the body in the administration of Life ${ }^{126}$ to much more continuous and invidious extent than the priest or the King had ever done. What these effects were in the service of depended upon how these varieties of subject-specific sovereignty perpetuated, closed-down and arrayed sets of relations.

Central to all discursive practice, then, is the body. The body is both a useful and an intelligible object. It is a deployable aptitude. It has economically productive capacities in its machine-likeness. It can also be made to produce intelligibilities and visibilities (especially "normal" and "abnormal"), by virtue of its amenability to inscription, its ability to be shaped, its displays of personality, its temporality, its mobility, and its visibility. It is a unique node of power relations.

\section{The Female Body and Discursivity}

Female embodiment offers a surface for power/knowledge. What roles are available for authority? What role does the authority of pregnancy and then motherhood perform in inclusion and exclusion, in public and private worlds?

Right off the mark I would like to address the irksome question of how to differentiate "agency" from "complicity".

Using a Foucauldian analytics of power, we are not permitted to give an account of the forces which locate an individual as subject to forces which are entirely external to, and acting upon, that individual. The overall effect of strategies of power -- the places and relations we find ourselves in and the parts of reality which I think of as me and not you, 
"is an effect that is manifested and sometimes extended by the position of those who are dominated". ${ }^{127}$ If women-as-mothers means, (among other things) experiences of oppression, domination, lack of agency, poverty, confinement, limitation (and many would argue that for all its emotional payoff this describes motherhood as a economic or political state quite accurately), and if this range of experiences is anchored in the private (as it seems to be), then women-as-mothers-to-be and women-as-mothers play a catalytic role as a condition for the division of the public from the private; in the extension of the private realm to and as themselves.

What is possible and what is then lived out as our experiences, our self-knowledge and agency, must be examined in relation to how a series of ontological and epistemic commitments which we ourselves hold, were among the conditions that made those possible.

...the precritical analysis of what man is in his essence becomes the analysis of everything that can, in general, be presented to man's experience. ${ }^{128}$

Let me be clear: I am not holding women solely responsible for our own oppressions.

I do claim that we can play a role in them. This is what Foucauldian analysis tells us we have to begin with. Critical alliances between feminism and postmodernism are

Foucault (1979:26-7).

Michel Foucault. The Order of Things. New York: Vintage, 1970:341. 
indeed, "uneasy". ${ }^{29}$ There is resistance to subjecting all the targets of postmodern theory ("Mankind", "History" and "Truth") to the same level of suspicion. ${ }^{130}$ This is particularly true of the idea of the "Subject". The notion of the subject has two gendered variants which appear to be central for feminist normative projects. These are "woman" and "mother". These two are woven into patterns of "the public" and "the private".

Postmodern criticism uses a theory of power that forces me to position myself. As I indicated in the first chapter, this is a strength of critical ontology. When Fraser describes power as "drawing the line", she seems to be presuming, even as she critiques their fixity, ${ }^{131}$ that there are already something like public and private spaces, and a line between the two, and distinct groups which occupy those spaces, and have different amounts of power to change the location of that line. Her implicit statement is that woman have less power than men; that men, who have public power, redraw that line. And that they redraw that line in order to gain more power (from or over women). A Foucauldian analysis of power relations insists that power is never held, like a quantitative thing, but is always ever relational. It is these relations which are constitutive of self and the selfs positions, possibilities, perceptions rather than repressive and

S. Benhabib, "Feminism and Postmodernism: An Uneasy Alliance." Feminist Contentions. New York: Routledge, 1995:17-34.

130

See, for example, Nancy Fraser, "Foucault on Modern Power: Empirical Insights and Normative Confusions." Praxis International 1:3 (October 1981):272-287; Rosi Braidotti, "Images of the Void." Patterns of Dissonance. Great Britain: Polity Press, 1991:1-15.

131

Nancy Fraser. Justice Interruptus. New York: Routledge, 1996. 
external to the self. What this says to me is that I am internal to, and sometimes colluding in the production of my realities, including my relegation to social spaces. It suggests the not so pleasant thought that I am active in "power relations at the micro-level of society which help make possible certain global effects of domination, such as class power and patriarchy." 132 The story of "men" "having" "more" power than women "in" the public space captures very little of the microplay of relations which position different selves with different intentions along different nodes of a specific history, although I will admit that it is a story which captures something true about the macroplay of these relations.

An account which implicates me (however productively or unproductively) as $a$ constant, sometimes central, force in my own life, but not as the prior, prime and only source of both my potential emancipation or victimization seems to be the account which bests accommodates my empirical realities. It also offers a compelling normative anchor in the tradition of existentialism. ${ }^{33}$ It has agency in its structure as a permanent discursive node, though it makes no promises or universal statements about the probability or outcome of that deployment for any specific individual, in advance of his or her taking up those nodes. On the other hand, while an existentialist version of the subject preserves freedom and responsibility at the micro-level, it gives short shrift to forces outside the agent which different individuals, for a huge variety of reasons, are more or less able to

132

$$
\text { Sawicki, (1991:23). }
$$

133

S. de Beauvoir. The Second Sex. Trans. H.M. Parshley. New York: Vintage, 1989; J.P. Sartre, "Existentialism is a Humanism." Existentialism and Humanism. Trans. Bernard Frechtman. Hasket Press, 1977. "If existence really does precede essence, man is responsible for what he is." (25). 
negotiate as agency.

Critical theory, whether feminism or any other anti-oppression work, taking account of postmodernism is the work of combining or giving an adequate account of this apparent two-tiered ontology of forces: micro, with an account of agency and responsibility, and from the macro to the macro, with an account of the generality and impersonality of forces like "race", "private" and "gender" which individuals have relations to.

Agency or positioning cannot be the outcome of the intentional actions of individuals. Since Freud, we have to reckon with the fact that the transparency of an individual's intentions to her own self is only ever partial. ${ }^{13 s}$ With Foucault's analytics of power, we admit that inversions are taking place alongside the "intended" results, a descriptor to which evaluations of culpability cannot readily be attached. Agency, then, (and thus empowerment, thus responsibility) is not about freedom from power, or emancipation once and for all, but involves the possibilities of understanding and adjusting the multiple forces (including my roles and my desires for them) which continuously and partially condition me as an included or excluded subject on a particular discursive field. It is in an understanding of the machinations of forces that we can arrive at an account of the ways in which an individual is an agent, in this complex sense of agency, in his or her own situation. In the remaining section of this chapter, I will look at York: W. W. Norton, 1961. 
bifurcating forces in natality. This will lead us to the next chapter where I look more closely at the role of the uptake of subjectivities in the domain of property. In the fifth chapter, I return to this difficult question of giving an adequate account of overall forces by adding another evaluative dimension: the formal features of the general forces.

While many traditional feminist accounts of the relation of the female body to female oppression concentrate on external agents of control - especially the media -several feminists have made use of a Foucauldian critical position to include the role that women play, as figures of authority, in the creation of their bodily selves. Susan Bordo has written about anorexia nervosa, Sandra Bartky, about female beauty, and Jana Sawicki about reproductive technologies to name just some of these. Using a Foucauldian model of power they recoup agency for women in their own bodily experiences, and give a more convincing account of the positive, enhancing role that self-control and competencies play for many women across many cultural frameworks.

..one reason why such technologies [makeup, dieting, IVF] are so effective is that they involve the acquisition of skills, and are associated with a central component of feminine identity, namely, sexuality. ${ }^{135}$

Women create relations of self-identity and investment around their bodies because their bodies represent an opportunity (for them, and for others) for the development of skills, authority, competency, knowledge. I am not claiming that this isn't also the case for men or even for children. I am suggesting however, that one of the conditions for differentiation is the real or perceived need for a certain skill which only women's bodies 
can perform. If that distinct performance is prostitution, filling surveys or helping product sales, then this will be a body-in-public, since the other relations and forces which produce "prostitution" are the same conditions which product the effect of "public": marketing, consumption, masculinity. Similarly, if that performance is wifely, nursing babies, or chastity, that performance will be a body-in-private, given the alignment of these kinds of production with all the other forces which inscribe women's sexuality, fertility, morality as a (largely) set of private relations.

In the case of the potlatch, the evolution of exchanges promoted a tally-keeper where none was previously required. In this change came the emergence of "expertise" and also its lack. This tally-keeper, by virtue of this emergent competency, gained status in the culture. This is not unlike "Web Masters" now. A co-condition of the emergence of expertise is, as we saw, that status and respect is scarce. The creation of a useful, admirable or even simply odd set of skills will then occur. Whether that role is suggested by the whole or suggested by the individual herself makes no difference to the structural changes which ensue when such a role is taken up and made good use of. Structural changes result in a "niche". That niche might be economic, aesthetic, epistemic or simply locational. For many young women, the usefulness of competencies of service, sexuality, beauty and appetite management is great. ${ }^{136}$ That usefulness has changed historically, and is varied anthropologically from other uses such as the verification of lineage (a function women's bodies can perform exclusively) to the production of a workforce or a cleansed 
race. I am thinking in this last example of the rape of Bosnian women by Serbs in the former Yugoslav republic. Presently, in most corners of the globe, not only does a female beauty ideal sell almost every kind of object on the free market, but females attempting to attain that ideal for themselves spend an extraordinary amount of time and money on products and devices which will hone them. ${ }^{137}$ Slimness and youthfulness - female bodies under control ${ }^{13 \mathrm{x}}$ - are marks of status for women, sometimes for themselves, sometimes for the men that have these women on their arms. Some female bodies have more permission than others to be in the public sphere. ${ }^{139}$ To this we add the long tradition of the amenability of the female body to administer morality, to illustrate its ideals and pathologies both in religious and in secular culture.

Moreover, the ideals of feminine bodyness are extremely valuable to young women, for whom there seem to be (or are perceived to be) very few opportunities to become unique, competently skilled, authoritative, respected, empowered; ${ }^{1+0}$ that is, knowers of much at all. While some might object that the "female beauty ideal" is [strictly] a form of oppression, again, I would qualify that response as not so much

S. Bartky, "Foucault, Feminity, and the Modernization of Patriarchal Power." Feminism and Foucault. Eds. Irene Diamond and Lee Quinby. Boston: Northeastern, 1988:61-86.

On the "threat" that women's bodily capacities serve in a culture of orderliness, see Pateman, (1989).

139

Bordo (1989:18) discusses the conditions of the female body which, at different times, granted or prohibited its access to public space. One example is the prevalence of agoraphobia among American housewives in the 1950's.

140

Bordo (1990:98) links anorexia with the need for the kind of respect afforded to women who demonstrate to themselves and to the world, that they are in control. 
inaccurate as incomplete. There is a great deal more going on in the relations that a young woman has to the culture of female beauty, than the onset of a sense of inadequacy, although in too many cases, this seems to be a common effect. This discourse is a means to a number of other less reprehensible ends, not only an end in itself. What this is a means to will depend on many other factors, including race, class and personality. In my own case, a fascination with products was what prompted me to organize some means of attaining spending money and of saving it. This was later replaced by records, then tuition. Even at the age of fourteen, I only spent a portion of that earnings on lipstick; eventually, the habit of being economically self-sufficient was my own. It is a central factor in my present capacity for self-respect and autonomy. Another dimension is that attention paid to the body is not, by definition, pathological. There is a place for building into one's life good eating habits, adequate exercise and rest: nothing much can happen in the long run if one isn't well. If "the feminine beauty ideal" starts young women down a path of fitness for the wrong reasons, this doesn't say that at some point down the road, the intentions behind that activity, for some women, will change. To overlay this possibility with a master narrative about oppression is to deny women the chance to rethink their motives. Again, I might have started out in sports partly because I was worried about being too fat: thirty years later I still exercise daily because if I don't, I will feel terrible and won't be able to be healthy and happy. Looking at bodies of other women is, for many young women, arousing, sexually and aesthetically. I certainly welcomed this chance to gawk at women's nipples and triangles, a delight and a curiosity 
which had been repressed and denied until then. It isn't that the feminine beauty ideal provoked mixed-up queer horny feelings: they let those be a part of me that the world outside of my head (and almost every other girls') finally affirmed. Again, I think that this can be the route into positive sexuality and body image in a way that the alternative doesn't seem to be able to affirm. Finally, one young woman and I, reflecting on our previous heavy consumption of "Teen 'Zines" and our present relative sense of strength and health told me that if it hadn't been for those things, she and her elementary school friends would never have spent any time together or known how to begin conversation. One way you can read this is that it begins to get girls to make connections with other people than those in their family, in other words, can cultivate a sense of independence. These alternate readings suggest not that the oppression lies, strictly, in the bodily ideal but in the lack of opportunities, authorities, subjects of expertise that this can segue into. ${ }^{141}$

\section{A Return to Natality: Authority and The Visibly Pregnant Female Body}

The visibly pregnant female body complicates matters. This is new kind of body and thus a new and fecund site for power/knowledge. Relations of power/knowledge in pregnancy are not limited to the pregnant woman and her fetus, but may include: the other parent and the fetus, the family and the woman, the woman and her sexuality, the society and the child-to-be, the gynecologist and the woman. The abortion debate

The story that this ideal, and the competencies it invites is only oppressive is itself a way of blocking the affirmation that there are routes out of this: in a sense it says that exposure to this ideal damages women irreversibly and that their own efforts to overcome this damage are ultimately worthless, incompetent. 
suggests links between cells and the woman and God, while the pro-choice view promotes the relationship of the woman to her body as if virtually exclusive. Neither of these does justice to the pregnant body as a set of relations. A Foucauldian account of power suggests that relations need not be close and personal to be effective: it is often a tenuous connection which forges profoundly important or damaging effects.

My own experience confirms that the state of pregnancy, because of its visibility, novelty, its seriousness and its extreme usefulness as a signifier, invites an entirely new set of power/relations to the subjectivity, the pregnant woman. Strangers touch you. You take up a place in a history which is Motherhood, which often means, among other things, a different relationship with one's own mother. Ads target your food, sex, and beverage choices as moral dilemmas. Your choices are suggested as instinctual rather than rational. Sometimes, like when you involuntarily lactate, your self feels more instinctual than rational. You are a number, a procreative agent, a population carrier. Your visible sexuality means an entirely different thing to you and to everyone else. Having lived in very small towns, where privilege and status is even rarer, I can also confirm that pregnancy offers to many young women what appears to be an excellent opportunity to become unique, skilled, authoritative empowered knowers. In my grade eleven class, two girls out of twenty had children. By grade thirteen this had increased to five girls with children. Only two of us went on to higher education. Most girls married and had children and became authorities in the private realm eventually. Susan Moller Okin, writing about the relations between sex difference, self-esteem and the deep 
structures of inequality found in most families suggests, in concert with my analysis, that the opportunity of mothering-as-authority is a gender-affirming choice which truncates other opportunities for other, less gendered, authoritative selves to follow after or even alongside motherhood:

...the occurrence of pregnancy among single teenagers, which is almost entirely unintended, would presumably be reduced if girls grew up more assertive and self-protective, and with less tendency to perceive their futures primarily in terms of motherhood. ${ }^{1+2}$

Standardly, the state of being pregnancy offers to most women a certain relationship of expertise with their biological selves in "daily regimens and time-tables...drills, training exercises, examination and surveillance techniques." ${ }^{1+3}$ Here, the fixation with the female body is relatively free from judgment of narcissism, and, a moderate amount of attention to the state of one's health is probably the most responsible relationship between a woman and her fetus. The trend in North American, however, is more than a moderate involvement with the pregnant body.

Moreover, in the North American context, this relationship always includes professionals, the specific intellectual. The primary institution which opens onto a pregnancy is, of course, the life sciences, medicine (obstetrics and then pediatrics). It is not a coincidence that the most necessary public part of my pregnancy was the part that had to venture to the gynecologist's office. 
What role does the professional, institutionalized physician plays in the production of the expectation to enter into relations with him or her at intervals during pregnancy, and then, as a demand, during labor? What is that surface which collects and then proffers knowledge to him or her and not necessarily to the woman herself? And to whom is this expertise offered? These are enormous questions, and I can only venture a few remarks from my own experience. ${ }^{1+4}$

Scientific knowledge is the kind of knowledge which most pronouncedly carries the whiff of truth in present culture. This is because of the role that scientific knowledge plays in establishing the criteria for normalcy. Normalcy is a concern which applies as much to pregnancy as to beauty or cancer. The power of normalcy means that gains in "knowledge" embed one in relations of power. These are not necessarily increases in power, empowerment. Emily Martin, a feminist sociologist of science, has studied the ways in which modern scientific knowledge has not "delivered" on its Enlightenment promise to emancipate and empower humankind. She concentrates her research on the relationships between scientific advancements and the empowerment of the women who are the subject of research. Martin's critical findings suggest that, while there is, without question, an exponential increase in the amounts and kinds of information available to women about puberty, pregnancy, menopause, this information isn't necessarily answering central questions and concerns that women have. Nor do women make use of a Advertising in the Mid-Victorian Era." Body/Politics. Eds. Jacobus, Fox Keller and Shuttleworth. New York: Routledge, 1990:47-68. 
scientific model of menstruation to explain to young women the phenomenon of menstruation. ${ }^{145}$

While a pregnant woman might be experiencing new things, and, with inductive reasoning, making some sense of the rapid changes in her body and life, there is nothing in that which tells her that what is happening is normal and therefore falling within the acceptable range. Since she is often identifying totally with pregnancy (or being identified by others as being a hyphenated kind of being), this means that she requires the judgment from an expert in order to determine whether she is, actually, normal. During the course of a pregnancy, the role of the scientific relation is to administer the on-going judgments of normal or abnormal. It is the normal/abnormal and the subjects who are in a position as experts to assert that distinction which constitutes the line of inclusion or exclusion around which there is either privacy or publicity during a pregnancy. To establish one's position requires perpetual surveillance: interview and quantitative analysis; that is, normalcy is largely a statistical matter.

This isn't as straightforward as it sounds. On the one hand, since the majority of pregnancy factors (like blood pressure or fetal position or rate of weight gain) fall within an acceptable range, what the relationship with one's doctor effectively pronounces is a lack of uniqueness, of specific, rather than generalized subjectivity. As a public matter, all pregnancies approach equality. Apparently, this also applies to the woman in labor, There is no room for individuality, the woman is efficiently prepared upon 
arrival at the hospital, and her body, as a machine, must effectively deliver the baby within strict guidelines, or it is considered defective and in need of intervention. ${ }^{146}$

An apparent normalcy, however, does not excuse a pregnant woman from a relationship of subjugation to the medical field, because while pregnancy is defined as "a normal health event" (this definition, presently, serves also to delimit the kind of birth which midwives in Ontario can oversee), ${ }^{147}$ the normal is the same as the medical. It is also the same as the sovereign subject, the pregnant woman.

But the medical truth of pregnancy and childbirth is not nearly complete: doctors do not necessarily understand it completely, nor do other "birth experts" including midwives and mothers who have already borne children. In order to understand it better, there are an infinite number of surfaces of the experience of pregnancy and childbirth which could be investigated. For each one, there would be a kind of range of "normalcy" to reassure from. Determining "normalcy", however, through the collection of data is simultaneously a known and an unknown. Some piece of information is generated, which can be situated on a standard distribution, but the standard distribution is always being built up: it is never so complete as to tell us, once and for all, that a given condition is or is not normal. Statistical analysis understands itself to be radically open in the sense that the norm is never established once and for all, but whether a given individual understands

Barbara Katz Rothman, "Midwives in Transition: the Structure of the Clinical Revolution." Social Problems. 30:3 (1983):265. [This may have changed slightly by now, but likely only in urban centers. I have only anecdotal evidence (from friends who've recently given birth) which suggests that this hasn't changed much.] 147

Association of Ontario Midwives. "What is a Midwife?" http://www.aom.on.ca/whatis.htm. 
her own relation to what can be said to be the case and what is still unknown about the case, is another question. There is a general trust accrued to numbers, even more so when one is in the midst of a novel and serious situation like having a child. Part of the upshot of that trust is a willingness to constantly subject oneself to testing.

This testing can, at best, generate a longitudinal picture of one's own pregnancy as falling within the norm for a given sample of pregnancies, and this requires constant monitoring. While the woman is submitting to a test in order to become "informed" and empowered, she is producing the information which vindicates the fact of the test. A test will always generate some result. But that result is not necessarily able to transfer a level of certainty or authority to her. If there is a power relationship to be had in such medical interventions, it will remain (like the tally-stick or the parlor chits and the ones who could read them), with the ones who can interpret the form that the results are presented in.

Let me give an example. In the last 20 years in North America, a technology of surveillance of the in utero heartbeat has been developed. This is the fetal heart monitor. This monitor replaces and improves upon the human ear and its immediate extensions, tools like the doppler-tone and the stethoscope. The purpose of the equipment is to monitor the stress of the baby, to determine if a baby is in any kind of danger. It improves upon the former registers in two ways: I) it is more sensitive than the human ear and thus can detect a heartbeat no matter where the baby is positioned in the womb; 2) it can be used to generate a visual equivalent (transfer from ear to eye) of the heart rate, on a paper read-out, which means that the practitioner can get a reading without having to be 
physically present. This reading is taken longitudinally, typically over a twenty or thirty minute stretch of time during labor. Now, without question, these monitors have saved the lives of infants in distress in utero. A seriously endangered baby can be almost immediately removed from the dangerous environment (the womb) via Cesarean section. However, this technology is clearly a double-edged sword. There is a high correlation between the mere use of the monitors and the number of Caesarean sections performed. ${ }^{+18}$ Should we suggest that human births have become, in twenty years of all human history, more dangerous for infants? No. I would suggest, though, that the fetal heart monitor has the capacity to suggest the presence of a pathological condition -- a distressed baby -because the heart of baby, in utero, experiencing twenty or thirty minutes of strong contractions will naturally accelerate and decelerate, and this flux will be visualized to everyone watching it, creating stress and anxiety. This is quite a different phenomenon from the expertise and assessment offered from the stethoscope, because there we are dealing with a technology which roughly matches in speed, kind, continuity and accuracy the event itself (the heartbeat) and the capacity of all the others to witness it (and form their own judgement). With the fetal heart monitor, there is a continuity and accuracy and form of information which does not match the level of general expertise of the spectators, nor the capacity of the physician to say whether and how a reading indicates a state of

A. Pedro, "Effects of Obstetrician Characteristics on Cesarean Delivery Rates: A Community Hospital Experience." American Joumal of Gynaecologist and Obstetricians 180:1 (1999):1364-1372; C. Sakala, "Midwifery Care and Out-of-Hospital Birth Settings: How do they Reduce Unnecessary Cesarean Births?" Social Science and Medicine 37:10 (1993):1233-1250; C. Sargent and N. Stark, "Childbirth Education and Childbirth Models: Parental Perspectives on Control, Anaesthesia, and Technological Intervention in the Birth Process." Medical Anthropology Quarterly 3:1 (1989):326-347. 
distress or something else. Together, this generates a picture of the event which suggests intervention, or, to connect this up with my earlier discussion, which provokes discontinuity. The doctors cannot necessarily reassure a woman about the normalcy or abnormalcy of these fluctuations, because these will always be a matter of degree, rather than an absolute. Ultimately, the overseeing physician gets the job of deciding whether or not a limit-condition has been approached or surpassed. The physician as the "expert" or the "professional" is an ideological by-product of this deferral.

With this deferral comes the power of agency. In the presence of information, and in the context which promises a safe birth, the physician will tend to err on the side of declaring the information as pathological rather than normal. This declaration is an order-word ${ }^{1+9}$ which instantaneously transforms the nature of the birth into a medical emergency. There is no corresponding declaration that the pregnant woman could utter which would enact such a transformation. ${ }^{150}$ This asymmetry is not a function of his being (usually) male and her being female: it comes about through the relations of expertise that particular techniques of knowledge establish with a subject whose position she holds, compared with a subject position which he holds in the specific scenario of labor.

During a pregnancy and during labor, what falls outside of normal is not interpellation and subject-formation, "Ideology and Ideological State Apparatus." in Lenin and Philosophy, and Other Essays. Monthly Review Press, 1972. that, the baby is coming!", she will not necessarily be heeded. It is only when the nurse sees the baby's head that the truth of this declaration is taken up. 
necessarily the part that can be left to women's own devices, but will likely be an abnormality (requiring even more intervention) or an irrelevancy. The private is the residue of all that which is irrelevant to the questions of normalcy; that is, to the political. Wherever a question of normalcy or deviance arises or even is suggested to be relevant, the lines dividing what is politically relevant ("public-interest requirements") from what is politically neutral (private matters) will be redrawn. This suggests that the critical, politically-significant factor in the question about the public versus the private, is whether and how lines can be drawn and maintained (performed), rather than whether or not they respect some predetermined set of rules regarding what is by nature, untouchable or not. Technologies, insofar as they are about means, are political and ethical, rather than simply the medium for their application. This is evident whenever a new means for erecting or bypassing barriers, such as barrier to "privacy", are developed and not all members of the general population can make use of them as means. ${ }^{i 51}$

The private is a kind of negation around which an reactive affirmation of a subject position is "built up"; whatever does not need to be, or cannot be, normalized (and that will entirely depend upon whatever aspects of her body or life are taken to be

ISI

Jeffery Rosen ("Cheap Speech: Will the Old First Amendment Battles Survive the New Technologies? The New Yorker (August 7, 1995):75-80) highlights how the issue of freedom of speech is really an issue of the capacity to regulate speech: “...the explosion of new media outlets means that centralized proposals to regulate speech are increasingly doomed to fail in practice, no matter how cogently they are framed in theory. It will be hard to police the "marketplace of ideas" when there are so many markets to monitor."(75) This observation about form (and specific positions relative to form), rather than content is critical to many debates besides the use of interventive practices in childbirth. Nadine Strossen. Defending Pornography: Free Speech, Sex, and the Fight for Women's Rights. New York: New York University Press, 2000 claims that the line between protected speech and illegal harassment can be drawn "only on an ad hoc basis, turning on all the facts and circumstances of each particular case."(11). 
relevant to the question of acceptability). She might be the one deciding that as much as her doctor, or a court order. Or other mothers.

\section{Mothering as Expertise of the Private}

The medico-scientific arena is not the only power matrix which comes to bear upon a pregnancy, a birth and then motherhood. It certainly is one critical field of power/knowledge. There is also the discursive field of motherhood itself. Motherhood is a patterned actualization which is the long term, relatively stable effect of moral, epistemic, biological, economic and sexual relations. Although the subject identity of 'mother" does not enjoy the kind of epistemic authority that health professionals generally do, "mothering" is, without a doubt, another important kind of power/knowledge formation.

Foucault divides us not into the ignorant and the wise, but into subjects of major and minor knowledge. This highlights not the content of what we know or do not know, but the kinds and numbers of relations of authority which we are able to establish within the cultural power grid. Minor knowledges he called "subjugated". ${ }^{\text {s2 }}$ Subjects of subjugated knowledge, though they do not enjoy a level of deferral and prestige afforded to specific intellectuals, nevertheless take up, and extend relations of power/knowledge in a variety of domains. They form part of what I identified earlier as "savoirs", "low- 
ranking, beneath the required level of cognition or scientificity". ${ }^{153}$

"Subjugated knowledges" refers not only to historical contents that are obscured within functionalist histories but also to those forms of experience that fall below the level of scientificity. The latter include the low-ranking knowledge of the psychiatric patient, the hysteric, the midwife, the housewife and the mother.... ${ }^{\text {st }}$

Sawicki and many others working in mothering theory take the status of mothers'

knowledge as minor, to be a major point around which to focus political action. Changes involve: 1) Women entering the scientific realm and working to legitimate their knowledge as empirically sound, as objective, as legal, as scientific. This is the route that Ontario midwives have taken. 2) Women refusing to enter the scientific realm, but rather, deepening a moat around "women's knowledges" as truth-bearing, and as the equal and opposite domain of truth belonging to women. It would be more accurate to say that this expertise is the domain of women who have experienced childbirth and motherhood. ${ }^{\text {ss }}$ Clearly, there is a kind of expertise granted to mothers. While a woman might not have seemed like an authority on the processes of labor and childbirth, everything is in place for her to appear to be a sudden expert, the unique one in the best possible position to make judgments, on and about the child, when that child emerges into the world. There

(ibid:82).

154

$$
\text { Sawicki (1991:57). }
$$

ISS

Much of feminist standpoint epistemology involves or makes reference to the bodily experiences of the menses, pregnancy, labour (either attending a birth or having a child) and parenting as the basis for this alternative epistemic authority. See, for instance, Linda Alcoff and Vrinda Dalmiya, "Are Old Wives' Tales Justified?" Feminist Epistemologies. Eds. Linda Alcoff and Elizabeth Potter. New York: Routledge, 1993:217-244; Alison Jaggar, "Love and Knowledge: Emotion in Feminist Epistemology." Women, Knowledge and Reality. Boston: Unwin Hyman, 1989. For a counterview, see Scott, (1999). 
are certainly residual medical interventions after a birth, but these decline exponentially, until a woman is soon "left alone". When she has doubts about her abilities to gauge whether a child's cry or fecal coloring is normal or not, she quite often asks another mother about this. Eventually, the answers that she gets convince her that she does know best, since she has established herself -- like the fetal heart monitor -- in the position of high accuracy, longitudinal indicator.

At a very practical level, the number of diapers that the person closest to the baby changes increases her skill at doing just that: it takes an enormous amount of somewhat artificial redistribution of that early grunt labor to ensure that a new father maintains the same status of knower vis-à-vis a newborn. Even if one is not enthralled by the status and deference that is automatically granted to mothers regarding newborns; that is, if one continues to assert her basic confusion and ignorance rather than suggest her special expertise and instinct, the conditions of early child care make it extremely difficult to distribute the role of expert witness to any other person. If you are breast feeding, as I was, you spend more than half your days and nights sitting alone quietly with the child. If you are bottle feeding, and able to share the labor with someone else, the fact that the child came out of your body still creates a strong gradient in favor of the assumption that this is the central source of an indisputable knowing. Such a gradient is easily built up if the general conditions are such that this is a relatively unique experience --psychologically, emotionally, culturally -- of affirmation, of recognition, of agency, of authority for the new mother. This sense of accomplishment and prestige will be heaped upon a new mother, and appropriated more readily if a woman has recently "given up" 
her career to have a baby while her husband has not.

Jessica Benjamin has suggested that in this complex of authority, a woman's own subjectivity is formed:

Some of a mother's ability to mother... what sustains her from moment to moment is the relationship she is forming with her infant, the gratification she feels when the baby...responds to her...in the first signs of mutual interaction: "I recognize you as my baby who recognizes me. ${ }^{156}$

The gratification in this expertise, taken up, divides one off from the whole as distinct. After girlhood and its plethora of ambivalence, and after a generic, medically and socially-monitored pregnancy, this distinction, and the privacy it affords, is a welcome experience. It is both welcomed by a woman for all its positivities, and encouraged from without by a culture for whom the mother-child dyad satisfies any number of other significations, religious, aesthetic, economic. The structure of this uniqueness is accomplished by the ways in which women are able to exclude others from that dyad, either emotionally, or physically, and the ways in which women are excluded from other sorts of relations, if only temporarily. Remaining for the most part in the home is how this is largely accomplished. I am not suggesting that this is malicious, selfish or intentional: it is a structural result of conditions which are hospitable to the rearrangement of power/knowledge where biological mothers can become authorities. It bears a structural relation to the questions of identity and knowledge in that in this, there is a discontinuity created between mothering and other discursive domains.

If we have not forgotten the basic premise which motivates feminist 
interest in the Public/Private, which is that women in North American culture at the present time, tend to be associated with the private and that women in general, tend to be disenfranchised relative to men, then having suggested one of the forces which link these two together and extend them as a macro pattern, we cannot overlook the micro level, the role that the uptake of subjectivities of the motherto-be and mother play in reorganizing the previous continuities which we might have had to any number of other sociopolitical domains.

\section{Summary of Chapter Three}

In this chapter, I demonstrated how one of the main binaries around which the domain of property is organized - the so-called Public/Private distinction-collapses when we investigate more closely those factors said to establish these as distinct categories. Using observations from potlatch economies, set against the question of how to read my own natalist experiences, I showed how the public or the private are built up as if distinct and then animated, within a set of habitual power relations. The "nature" of the public/private then, will be nothing more than these relations. They inhere not only at the level of race, class and gender (macro categories), but are built up around a complex dynamic involving physical location, bodily posture, literacy, attitudes, epistemic and moral principles. This complexity suggests that we should think of the public/private as a functional binary organized in different ways by different persons: it is not homogeneous enough to be describable at a macro level, but neither is it so entirely heterogeneous as to be ungeneralizable as an individual phenomenon. The Public and the Private can not be described in terms of amounts, since they are nothing more than these relations, not 
things which those relations are about. A critical analysis of the workings of the public and the private, therefore, must be about the kinds of forces involved in the production of a binary, the numbers of relations involved, and the effects of these. A normative or an historical account of private and public property patterns, likewise, must include the workings of these forces.

My chief critical observation about the production of "the private" was in regard to the role of authoritative knowledge, in particular, the authorities afforded to pregnant women and new mothers about childcare, and the authority afforded the potlatch tallyboy about the exchanges which had occurred. Each of these authorities is linked to an economics which has property among its chief components.

The capacity to claim authority in a domain is linked to the capacity to exclude. Whereas, as we saw in the previous chapter, traditional and commonly understood ontologies of power (such as Locke's), tend to locate the power to exclude or include in either the State ${ }^{157}$ or the pre-social autonomous agent, and through a repressive rather than an augmenting dynamic, under a Foucauldian account, the ability to exclude or include is a capacity linked to affirmative subject positions. The power to exclude or include (other places named "control" of a situation), lies chiefly in the tenacity of the claims of expertise. The tenacity of authority is a reflection of the intensity of power relations reflected in it. Power, thus, is not garnered at the level of the macro or random/abstract individual; again, it is always a subject-specific capacity. A person may wield power over 
another, and think that $\mathrm{s} / \mathrm{he}$ possesses power, but in effect $\mathrm{s} / \mathrm{he}$ is a node in the circulation of power.

This authority has an affirmative nature from the point of view of the subject; a permissive function. For,

...power would be a fragile thing if its only function were to repress, if it worked only through the mode of censorship, exclusion, blockage and repression, in the manner of a great Superego, exercising itself only in a negative way. If on the contrary, power is strong this is because...it produces effects at the level of desire and also at the level of knowledge. ${ }^{\text {ss }}$

It is difficult to deny that the forces shaping natality as an experience are strong and reinforcing, rather than fragile and prohibitive. They are certainly tied up with desires and tensions around what is permitted and what is prohibited, the pattern of which fixes a public/private narrative. This patterning is 'available' as a kind of template upon which one can organize the many dimensions of being pregnant, delivering a child and being a new mother. The oft-cited positivities of these phases of natality form some of the standard voice which "cites" the experiences from the subject position of a pregnant woman or a mother. It is in the performance that the authority of the subject position gathers itself:

...the subject who "cites" the performative is temporarily produced as the belated and fictive origin of the performance itself. If a performance succeeds, then it is not because an intention successfully governs the action...but only because that action echoes prior action, and accumulates the force of authority through the repetition or citation of a prior and

(ibid:59). 
authoritative set of practices. ${ }^{159}$

I have made the claim (and I am not the first to make it), that when we align the uptake of the performative of the private by mothers and by Aboriginals with the domain of property, there are a number of side-effects which we should be concerned about. I will quote at length from Joan Kelly-Gadol, because what she has to say reflects directly upon the connection I was making between Potlatch economies in transition and the negotiations of the private and public that contemporary women make in a society which is basically that kind which Potlatch cultures evolved into:

\begin{abstract}
Although what constitutes "domestic" and "public" varies from culture to culture, and the lines of demarcation are differently drawn, a consistent pattern emerges when societies are placed on a scale where, at one end, familial and public activities are fairly merged, and at the other, domestic and public activities are sharply differentiated. Where familial activities coincide with public or social ones, the status of women is comparable or even superior to that of men... Where the domestic and public orders are distinguished from each other...women...steadily lose control over property, products, and themselves as surplus increases, private property develops, and the communal household becomes a private economic unit, a family (extended or nuclear) represented by a man. The family itself, the sphere of women's activities, is in turn subordinated to a broader social or public order - governed by a State - which tends to be the domain of men. This is the general pattern presented by historical or civilized societies. ${ }^{160}$
\end{abstract}

The authority of mothers come to occupy and stand for everything that is antithetical to

159

Judith Butler. Excitable Speech: A Politics of the Performative. New York: Routledge, 1997:46;51. Foucault calls the speech act which fulfills this dynamic function "commentary" and the performer of these "the author function": "Commentary limits the hazards of discourse through the action of an identity taking the form of repetition and sameness. The author principle limits this same chance element through the action of an identity whose form is that of individuality and the $I . "$ (in "The Discourse on Language." (1972):222).

160

Joan Kelly Gadol, "The Social Relation of the Sexes." Feminism and Methodology. Ed. Sandra Harding. Indiana University Press, 1987:22-23. emphasis added. 
property. The actual physical space that mothers occupy, like the single family dwellings that the Kwakiutl moved into, becomes the means to differentiate one domain from another, and in turn, to offer a scaffolding upon which further moral, bodily, aesthetic, economic, psychological and epistemic distinctions can be built. These were the same ones which we began with in this chapter.

One Last Note about the Relationship of Liberal Theory to The Public/Private Divide

In the first chapter, I argued that Liberal Theory itself plays a role, though not necessarily transparently so, in the installation of its own authority from which it assesses the sociopolitical domain. The Public and the Private, in Liberalism, are carefully and explicitly distinguished, yet mutually dependent. Insofar as Liberalism is used as a critical tool, it extends the distinctions it presupposes, which is to say that they are widely extended since Liberalism is widely taken up as a critical tool.

Liberalism organizes the public/private distinction around gender, and in this too, it confirms and extends that distinction. Liberalism at the macro level works toward equality of persons, but at the micro level, different patterns are entrenched which can work against equality. As I claimed in the last chapter, this is not entirely evident, or even understood as linked, unless a Foucauldian account of power is one's frame. The social pattern that is presently gender inequality can be explored as the upshot of the formalization of other forces and patterns of power. "Underneath" Liberalism there are formal, conceptual relations which have aligned men and public, and women and private. For, while Liberalism affirms a political realm as the realm of power and property for all, as a zone of actualization open to all autonomous adults, it also competes with that zone 
by positing a second, complementary zone of power: the domestic parental relation. In the case of the Maoris and the Kwakiutl, a complementary zone was not respected, and their attempted entry into that promised zone on its terms was a disaster for the Aboriginals.

Although Locke, in theory, offered "parental power" to both men and women by virtue of their joint roles as bearers and guardians of the young, in truth, this 'empowerment' has largely been reserved for mothers. Free men have patterned the public more than the private because recognizing and affirming women as bearers of children (and other labors of love), and men as bearers of property and title, "fell within the true"161 in the $17^{\text {th }}$ century in a way that the inverse did not. Moreover, the continuation of that pattern of discontinuity between the public and the private, and the relative occupation of each by gender, fell within the true not only because of the relative expediency of such an organization, ${ }^{162}$ nor simply because of an overarching repressive regime, but, as I have argued here, because of the way in which a bifurcation of expertise meant that women could be said to be, seen to be, feel to be, powerful in the home.

Foucault (1972:224).

Nicholson, “Intellectual Property Rights and Innovation." London: HMSO, (December, 1982): 19. 


\section{Chapter Four: The Subject and Property}

What powers we must confront, and what is our capacity for resistance today, when we can no longer be content to say that the old struggles are worth anything? And do we not perhaps above all bear witness to and even participate in the production of a new subjectivity?!

\section{Introduction}

In this chapter I will investigate the function of the positive, sovereign subjects of discursive formations. The main discursive field we look at is property. Using the field of property, we will see the roles that the sovereign subject plays in the formation and operation of a discursive field. In the last chapter, we examined the function of the private subject, which could be characterized as a negative subject of property. These functional roles inflect both tangible and intangible forms of property. The main point that I would like to argue is that they are not merely descriptive features of the domain of property, but normative ones. A related purpose is to reveal the significance of the subject and of subjectification, notions widely used in postmodern analysis, the significance of which may not be appreciated by other critical frameworks. The subject is, in fact, and should be, the basic unit of analysis. ${ }^{2}$ I will begin to make the case for this claim by sketching the limits of the traditional justificatory frameworks. These limits point to the role of the

Gilles Deleuze. Foucault. Trans. Sean Hand. Minneapolis: University of Minnesota Press, 1988:115.

I am not strictly interested in the subject as autonomous agent, i.e. in the states of the subject -"intentionality" and "consenting". I am interested in the way the position which is a subject position with particular capacities on a general field of power, functions. In this way, my attention to the subject differs from phenomenology and liberalism, although as I hoped I showed in the previous chapter, those positions are related to, and can be seen to play a role in the possibility of a subject position and what that position involves. 
subject. When we look at property debates which use economic principles, for instance, we discover that those principles taken alone rarely settle a question: equal and opposite courses of action can be built from the same premises. This is true of moral and political justifications.

\section{The Three Functions of the Subject}

The subject performs three distinct but related functions: modelling ideal personae, carrying normativity, and providing a formal ground for normativity. In this chapter we will look at the first two. Chapter Five will be devoted to exploring the third function. All three of these taken together will make the case that normativity is a matter of structure as much as it is of substance.

First, the subject is a kind of exemplary character or persona within a domain. This role is content-driven. For each domain there are its specific personages. ${ }^{3}$ There are techniques of personage construction and signs of personage recognition. This first function establishes a character norm internal to a discursive regime, an ideal against which all others are compared, either explicitly or implicitly. A co-result is that an anti-character norm is established as being external to the regime. We already encountered the anti-norm of ownership in the mother. This first function, then, has to do with how persons are individuated as subjects, identified, organized and ranked relative to others within domains. This subject function is observable in the domain of property: regarding tangible property we find the figures of the small-scale farmer, the craftsman

Foucault (1980b:62). 
and the local merchant, with a correlate set of techniques and signs for recognizing them. Regarding intangible property we find the figures of the author and the genius with their particular features.

The second function that the subject performs is the carrier of normative capacity. Moral, economic, aesthetic, social or epistemic principles are shunted into domains and given their force within those fields only if they are "carried" by, or applicable to, a recognizable subject. Power/knowledge relations inhere in an actualized subjectivity and give force ("appui")" to other relations. Here, I am not trying to answer the question about the source of moral principles. Saying the subject is a node to work through does not say either that the Good is nothing more than what the social evolution of individuals produces as its Good, or even that there is a foundation to Goodness. It is the claim that the Good needs an active site to work through if it is to have or be force, regardless of whether the Good "comes" from Nature, God, or convention. Each of the personae identifiable under the first function is able to "perform" its normative roles by virtue of these underlying relations or values which they carry and express. Therefore, to analyze the subject-function in domains, we must not just identify their typology (their specific content) but the kinds of values which they carry (their general content) and where they appear in the domain (their specific form). When we investigate the sovereign subjects of property, we will look at the values carried by these in the domain of property, as they are 1989:215. 
provided with a normative ground in those subjects.

However, more than just grounding normativity, in the aporea of traditional justificatory frameworks, the subject can be the key to deciding a course of action. The figure of the subject can be used to emphasize particular justifications and arguments rather than others. The subject, then, as part of this function of normativity, often performs an additive function of decidability. This 'decidability' is connected to the kinds of ontological presuppositions which particular subject positions have built into them. I will make explicit how the traditional normative principles within debates about property are, in fact, dependent upon the subject function both as a shunt and as a decidability factor. I will show how this is so for the two fields of property, land and ideas. I will also make apparent what I take to be the underlying ontological presuppositions which "undergird" these subjectivities as a way of moving us toward thinking about subjects in terms of deeper features which they "have" and thus features which they "give" to discursive fields.

An Expanded Role for the Subject Suggested by the Limits of Traditional Justificatory Frameworks

I will briefly sketch some obvious aporias in the dominant evaluative frameworks which have been used to debate issues of property. In this section I cannot do justice to the scope of traditional debates justifying one form of property over another, or one particular cases of property as more defensible than another. My aim is to focus on the role that the subject plays in these debates, without, I hope, oversimplifying what I do present of them. 
The two traditional approaches to justifying property as such, and to justifying case by case instances of ownership, are an economic approach and a moral approach. This extends to debates on newer forms of property such as copyright. One finds, among economic and moral considerations, aesthetic, qualitative, ${ }^{5}$ legal, and religious ones; however, it is safe to say that these values no longer dominate the debate. When they do appear, they are underwritten by moral or economic principles. This is true of legal values. What I want to show here is that these, in turn, are underwritten by subjectivity. Private property in land and private property in ideas have both been justified or denounced according to economic principles: whether a general form or specific instance of property is worth developing and defending depends upon the commercial possibilities or market efficiency revealed by cost-benefit analysis. Since there is a translatability between utilitarianism and economic principles -- one way in which outcomes in terms of relative happiness can be quantified and compared in order to indicate the utility preference is in terms of how much money people would be willing to pay for such an end or pay (as in insurance) to avoid such risks -- here, "moral" and "economic" principles do not represent two separate justificatory frameworks.

Value...is to be fixed in economic terms, measured by the yardstick of human satisfaction as determined by what we would be willing to pay for that satisfaction...to establish the amount we would be willing to pay might be difficult [or culturally unacceptable as practice] but, so

Locke's Second Proviso, that acquisition of property is justified "at least where there is enough, and as good left in common for others" (Second Treatise, Ch.V:27) is a qualitative limitation. 
proponents of an economic theory of value believe, not impossible."

The basic goal shared between economic and utilitarian frameworks is that the greatest good is the greatest overall outcome, and that greatest good is the net sum of costs versus benefits, however those costs and benefits are defined or assessed'. A second convergence of economics and normative principles can be found in the frequent assertion that the rules which are efficient are also the just rules."

Private property in land and private property in ideas have also been justified or denounced according to moral principles: whether a general form or specific instance of property is worth developing and defending depends whether it promotes some aspect of the Good. Elements of a moral framework would be those things considered inalienable, non-fungible, ${ }^{9}$ unquantifiable; whatever lies beyond or above the reach of the market. This moral/economic split maps classic distinction between intrinsic and instrumental values. The former might include: dignity, identity, virtue, character, love and other feelings, belonging, environmental values, justice, life, self-worth, respect, rights,

Tom Regan. Earthbound. New York: Random House, 1984: 9.

7

David Friedman, "A Positive Account of Property Rights." Social Philosophy and Policy 11:2 (1994):1-16; Robert Sugden, The Economics of Rights, Co-operation, and Welfare. Oxford: Blackwell, 1986.

8

Friedman (1994:13).

9

Margaret J. Radin, “Property and Personhood." Standford Law Review 65:1 (November, 1991):960. 
equality, freedom, health, species.

Many deny that these concepts point to a separate category of analysis. "Species as such have no value...but neither does anything else, neither truth, nor beauty nor non-economic goodness." that if, at a given time and place, love is not bought and sold, this merely reflects a cultural norm rather than a universal distinction between kinds of values.

Whether there truly are any values beyond economically-convertible ones is not a question I will answer. Since non-economic values are cited as distinct from economic values, and are used as principles around which justifications of property are organized, I will treat them as separate justificatory frameworks.

Given the scope of moral and economic debates about property of all kinds, we might suspect that these each provide a set of clear, free-standing, normative principles that can guide our judgments about property in a consistent and sound manner.

Unfortunately, neither "morality" nor "economics" provides an adequate and independent set of justifications. One cannot pursue a foundationalist strategy in moral theory or in economic theory because any normative principle would presuppose certain assumptions about the subject, about property relations, etc. Each relies on normative force garnered from beyond the terms of its framework. Sometimes that normative force can be found in the sovereign subject which "lurks" behind an ethical judgement. In some cases, it relies on the normative force which is a part of the structure of a set of 
ontological commitments regarding the nature of the subject and the nature of the object. I would to consider the limits of the normative frameworks which economics and morality work with.

Economics provides an entire army of justificatory principles which are brought to bear on the institution of property. Property in general, or particular examples of property, and laws regarding property, are good, fair and desirable, insofar as they promote any of the following positive economic principles: "growth", "efficiency", “profits", "gross national product", "competition", "fair dealings", “benefits", "development", “increased gross national product", "higher standard of living", "volume sales", "international investment", “fair pricing”, "availability of luxury goods", "resource management", “decreased costs", "choice maximization", "reduced scarcity". Not surprisingly, these principles are voiced most often as part of normative arguments in business and trade R\&D circles. These principles can be worked up to evaluative frameworks which give definitive answers for research and development options. In many instances, "gross national product", and "standard of living" are taken to serve as adequate, practical indicators of the welfare.

Economic justifications for property take the form of the claims that certain forms of property, (and a system for policing and administrating these forms) are necessary to provide "the greatest overall efficiency and the maximum welfare in the economy";" that

Paul Steidlmeier, "The Moral Legitimacy of Intellectual Property Claims: American Business and Developing Country Perspectives." Joumal of Business Ethics 12:2 (1993): 160. 
the present and future adequate standard of living of humanity depends upon a particular system of property.

Since the 17th century that particular system of property has been private property: the ownership of individually-identified things and ideas by clearly identified individuals. A condition of exclusivity is necessary for buying and selling. Laws are necessary to adjudicate between conflicting claims to property, which is taken as inherently scarce. With respect to tangible property, here are several of its key supporting premises, and some quotations in support of these.

1). That alienability is necessary to the growth and security of nations, corporations and persons; that individuals will not apply themselves to working land (or other value-added activities) in the absence of economic security; that leaving distribution to the market increases freedom and value; and that overall utility is increased when persons are industrious,

In their concern with the negative externalities from exclusion, the opponents of private property tend to forget the positive externalities that are the unintended but welcome side of voluntary trade: the increased wealth created additional opportunities for third persons to enter into win/win contracts of their own. Institutions of common property impost costs of coordination and may dull the incentives for production and trade that a system of private property nurtures. ${ }^{12}$

2). That people deserve to benefit from their labors while those who do not labor do not deserve to reap any benefits and that free-riders who drain rather than contribute to the world are rampant in common property holdings:

Richard A. Epstein, "Private and Common Property." Social Philosophy and Policy 11 :2 (1994):22. 
If I despair of enjoying the fruits of my labour I shall only live from day to day: I shall not undertake labours which will only benefit my enemies. ${ }^{13}$

3). That the condition of scarcity in a climate of fecundity requires the protectorate (legal and moral) offered by privatization,

If every member of the community were assured of subsistence for himself and any number of children...prudential restraint on the multiplication of mankind would be at an end, and population would start forward at a rate which would reduce the community, through successive stages of increasing discomfort, to actual starvation. ${ }^{\text {i }}$

4).That the free-market system, based upon private property rights, is the most efficient mechanism for allocation of resources and policing rights,

Detecting the presence of a trespasser is much less demanding than evaluating the conduct of a person privileged to be where he is.... when land uses have no spillover effects, individual ownership directly and precisely punished land misuse and rewards productive labor. ${ }^{\text {is }}$

5). That the sovereignty of personhood is tied up with and dependent upon exercising the rational choice to maximize one's goods. Therefore, the overall greatest good for the greatest number is achieved through private property rights and a system for distributing and policing these.

Jeremy Bentham. Principles of the Civil Code. R. H. Tawney, 1978: 136.

John Stuart Mill, "Principles of Political Economy with Some of Their Applications to Social Philosophy." Property: Mainstream and Critical Positions. Ed. C.B. Macpherson. Toronto: University of Toronto Press, 1978:81.

15

Robert Ellickson, "Property in Land." Yale Law Journal 102 (1993): 1327. 
The very same arguments appear in support of intellectual property, suggesting that property in ideas has by and large been subsumed under the traditional justificatory frameworks. The central arguments in support of intellectual property echo those above: that copyright protection is necessary to encourage innovation ${ }^{16}$ (creativity) and the production or expression of ideas;" ${ }^{17}$ that private property in ideas increases the diversity, spread and use of information ${ }^{18}$ and products derived from new ideas; ${ }^{19}$ that one's mind is the most personal property and that one has a natural right to its products ${ }^{20}$ that property

IDRC Report 23:1 (April, 1995):22.

17

James Gleick, "Patently Absurd." New York Sunday Times Magazine (March 12, 2000). "Patents have long served as a fundamental cog in the American machine, cherished in our national soul. ...Congress is empowered by the Constitution 'to Promote the Progress of Science and useful Arts, by securing for limited Times to Authors and Inventors the exclusive Right to their respective Writings and Discoveries."(44).

18

Sheldon Jacobs, “An Update and Overview of Intellectual Property Rights in Thailand." Office of the Board of Investment, Office of the Prime Minister, Royal Thai Government. (1994): Sec. 2:2. I. "Both copyright, the exclusive privilege to make copies or reproduce tangible expressions of information and patent monopoly privileges for a specific term as a reward for the public disclosure of the details of the new invention...encourage the dissemination of information."(21).

19

Mary Knudson and LeRoy Hansen. “Intellectual Property Rights and the Private Seed Industry." U.S. Department of Agriculture, Agriculture Economics Report No. 654 (November, 1991):19pp. "The seed industry can be credited with providing agriculture with a diverse choice of higher yielding, more disease-resistance, and hardier seeds."(14)

20

Bettig (1996:25). "For when it came to literary activity there is 'no property more peculiarly a man's own than that which is produced by the labour of his mind." 
rights in the products of the mind will improve the quality of goods ${ }^{21}$ that the freedoms of thought and expression, and the responsibilities which go with expression of ideas $^{22}$ are best protected and regulated under regimes which guarantee proper attribution of thought to its proper source in an individual ${ }^{23}$ that it is not in the interests of a civil society, any given state, to allow intellectual talent to go undeveloped ${ }^{24}$ or to lie dormant ${ }^{25}$ that ideas are created via labour, ex nihilo and are therefore the belongings of one rather than all;2s that under provisions of private ownership the reputation and quality of the creator

21

22

23

24

Gustavo Vega, “Mexico, The U.S. and Canada: Issues and Prospects for Freer Trade." Center for Trade Policy and Law 16 (1990):4.

25

R. B. Nicholson, "Intellectual Property Rights and Innovation." London: H.M.S.O., (1983):25.

26 588.

John Sutherland, "The Great Copyright Disaster." London Review of Books (Jan. 12, 1995):3.

William Kingston. Innovation, Creativity and Law. Boston: Kluwer, 1990.

Allen Rosen, "Reconsidering the Idea/Expression Dichotomy." UBC Law Review 26 (1992):263-280.

James W. Child, "The Moral Foundations of Intangible Property." The Monist 73:4 (October, 1990): 
(author) are best respected; ${ }^{27}$ that privatization of knowledge makes no one worse off ${ }^{2 x}$ and is in the public interest; ${ }^{29}$ In short, that privatization of ideas is vital to the welfare of humanity ${ }^{30}$ in that it best means of securing a profit on them..$^{31}$

This is very significant given that some believe "the only wealth there is in the world today is the wealth that comes from the human mind." ${ }_{32}$ One finds very positive evaluations of intellectual property regimes in terms of dollars:

It has been estimated that an international IPR regime along the lines the US is proposing will result in higher royalty payments for developing

Clare Nullis, "Actress wins Rights to juliaroberts.com."http://www.nandotimes.com. (June 3, 2000); Bettig, (1996) "...reprinted books without the consent of the 'authors or proprietors' of copyrights 'to their very great detriment' and 'damage' to their families."; Mark Rose, Authors and Owners: The Invention of Copvright. Cambridge: Harvard University Press, 1993, re: objectionable advertisements, dust jackets in poor taste, commercial ventures, logos...." (25).

28

Robert Nozick. Anarchy, State, Utopia. New York: Basic Books, 1974.

29

Horatio Spector, "Intellectual Property Skepticism." International Journal of Applied Philosophy 6:2 (1991):65-67.

30

Steidlmeir (1993:160). See also E.W. Ploman and L. Clark Hamilton, Copyright: Intellectual Property in the Information Age. London: Routledge and Kegan Paul, 1980:esp.175-181.

31

Nicholson (1983:1); Robert M. Sherwood, Intellectual Property and Economic Development. Boulder, Co.: Westview Press, 1990.

32

Linda Marsa, "Whose Ideas are they Anyway? Intellectual Property in the Information Age:" Omni (Winter 1995):37-41. 
countries that could reach an annual figure of US $\$ 43-\$ 102$ billion..$^{33}$

By and large, as guiding principles, economic/utilitarian evaluations have been used to expand private property regimes in land and in ideas from the West to the East, and from the North to the South. ${ }^{3+}$ They continue to be used to expand the circle of intellectual private property to include (mainly Western-held) patents on biological material obtained from developing countries: microorganisms and parts thereof, human cells (including blood cells i.e. entire genetic codes of aboriginal people) $)^{35}$ from disease-resistant "varieties" and "predisposed varieties", plant varieties already developed by indigenous farmers (rice, corn, neem, cotton), seeds and oils, medicines, animal species. Economic principles, backed by statistical data, can be worked into arguments in favor of encouraging the expansion of private property in ideas.

However, surveying the literature on property from multiple vantage points (not only the vantage point of, say, a member state of GATT or of an advisor to the U.S. Patent Office), we encounter the same basic principles (freedom, welfare, justice,

Paolo Bifani, "The New Mercantilism and the International Appropriation of Technology." Paper from Uruguary Round Roundtable, Delphi, Greece, (April 1989):167. Quoted in Chin and Grossman (I988) Intellectual Property Rights and North-South Trade

34

Jacobs (1994); F.M.Abbot, "Protecting First World Assets in the Third World: Intellectual Property Negotiations in the GATT Multinational Framework." Vanderbilt Journal of Transnational Law 22:4 (1989):705-710.

35

Including these "identified groups"/specific resistance pairings: Panamain Guyami:leukemia; Sudanese: malaria; Limone Italians: heart disease; Nairobi prostitutes: H.I.V. ; Papua New Guinea and the Solomon Islands: cancer. Marsa (1995:39). 
maximal utility, expression of human possibility), understood to be backed by other data, come to entirely different conclusions and thus argue for a radically different course of action. For example, another cost-benefit study of the adoption of international I.P.R. regime by Thailand suggested that developed countries would benefit while additional costs would be imposed on developing countries. ${ }^{36}$ Looking at the question of costs from a broader scope:

But are the lower costs which proceed from these competitive advantages...really lower costs for societies as a whole? What about increased poverty, pollution, unemployment, illiteracy, ill-health, environmental degradation and destruction of natural resources...? What of the loss of cultural diversity and autonomy of thought...? What of the increasingly inescapable pervasion of the globe by ever more motor noise, traffic, commercial interruptions and junk? ${ }^{37}$

For each and every normative statement made in the positive section above, there is another which argues for its opposite, either based on different data, a different way of counting value, a different set of assumptions regarding initial conditions or units of measure, a different (temporal or spatial) circle of assessment, a different interpretation of what "freedom", "efficiency", "justice", "well-being", "human nature" or "human flourishing" is (and even here, a different interpretation about how it would be best gained or expressed as a mode of property), a different political framework, a different

Bifani (1989:167). the Westminster Institute Conference, London, Ontario, Canada, (May 1995):7. 
ontology. To give just a small series of examples regarding the assumptions of "the

inherent connection between creativity, profit, and social welfare", ${ }^{3 \pi}$ the order of

knowledge and I.P.R. rights and profits, and, innovation's relation to individuals ' ideas:

...there is little evidence that patent protection stimulates innovation in plant breeding. Most of the great agricultural advances in the world came about without any patent protection. ${ }^{39}$

Our study demonstrated that scientific innovation depends on a mixture of basic and applied research, on interdisciplinary borrowing, on an unforced pace of work and on personal motivations that lie beyond the reach of the administrator's rule book. ${ }^{+0}$

...the knowing that we do as individuals is derivative, that your knowing or mine depends on our knowing, for some "we"....you or I can only know what we know (or could know), for some "we". ...communities that construct and acquire knowledge are not collections of independently knowing individuals; such communities are epistemically prior to individuals who know. ${ }^{+1}$

Virtually all commercial biotechnology companies currently have hundreds of patent applications sitting at the PTO'2 hung up in the

38

Bettig (1996:25).

39

IDRC Report (1995:22).

Gerald Holton, Hasok Chang, and Edward Jurkowitz. "How a Scientific Discovery is Made: A Case History." American Scientist 84 (July-August 1996):364.

41

Lynn Hankinson Nelson, “Epistemological Communities.” Feminist Epistemologies. Eds. Linda Alcoff and Elizabeth Potter. New York: Routledge, 1993:124.

42

This is true too, of software companies: "The largest corporations, with gigantic patent portfolios, routinely enter into cross-licensing agreements with their largest competitors. Companies without portfolios of their own have to pay cash, and the costs are sky-rocketing: revenues in the U.S. for patent licenses were about $\$ 15$ billion 
interference proceedings which determine who has rights to obtain a U.S. patent when two or more parties are essentially claiming the same thing... The system can be manipulated. Parties often file "submarine" patent applications...designed purely to manipulate the system for profit..on another person's research. ${ }^{\text {t3 }}$

Each of the principles by which property as a whole or specific instantiations of property are defended or denounced can be put to work to defend or denounce the same thing.

They can be and have been adapted to opposite viewpoints, "and used, in different forms, on both sides of every question to which [they] could conceivably be applied. " Neither economics nor ethical theories which make use of economic or other principles, provides a set of clear, free-standing, normative principles. The normative force of positions comes from outside the frameworks assumed to provide it. I would like to explore how the sovereign subjects of the discursive field of property contribute to the normative tenor of the domain. Economic and moral forces are distributed on and as a specific subjectivity, which lends economic, moral or aesthetic principles a scaffolding.

First Function of the Subject: Normative personae which organize and rank persons

Within any given discursive regime there are its particular subjectivities or

in 1990; eight years later they had soared to more than $\$ 100$ billion. I.B.M. alone took in well over $\$ 1$ billion from licensing last year and received a record 2,756 new patents." It costs, on average, more than $\$ 1$ million to challenge a patent. (Gleick (2000:46)).

43

Dale McDonald, “Who Owns Nature?" Home Farm 32:6 (March 1999):2.

44

G.D.H. Cole, Introduction to Jean-Jacques Rousseau's The Social Contract and Discourses. London: Fitzhenry \& Whiteside, (1973):xvi. 
personages. The capacity to describe such a subject is paired with the capacity to observe a subject; to see and point out, and mark these "personae" among the many, and then to name these as peculiar to a particular field. In secular modernity, the privilege of seeing, identifying and classifying persons in this manner has belonged largely to the human sciences: medicine (physical and psychiatric), law (penal and jurisprudence) and education.

In order to be respected as distinct, and justified as important institutions, each of these depends upon the identification of norms and deviants: without "normal subjects" there could be no ideal which pathologies could be bent toward, without "pathologies" there could be no incentive for intervention and without the relative arrangement of these (statistical distribution) there could be no human knowledge. Subjectitivities, then, always occur in pairs. Of a pair, one is always the positive exemplar against which all others permutations are gauged by virtue of the proximity to it. The exemplar may or may not correspond to an actual person or set of persons. It may be a set of attributes, a model. It may be created through test scores and surveys which themselves are part of the mechanism that led to the emergence of modern subjectivity, an individual. ${ }^{45}$ It may be an historical figure which embodies some feature, a feature still being responded to in the present as if present. Often, it is an archaic exemplar animating metaphors through which we try to understand, by analogy, very new developments in a domain. These analogies, which depend upon an animating, central figure, are not benign. An example is the Ian Hacking. The Taming of Chance. Cambridge: Cambridge University Press, 1990. 
archaic language of battle and the codes of behavior for soldiers of battle which peppers contemporary nuclear arms discourse. ${ }^{+6}$ In this discourse, we are also continuously introduced to the figure of "the Guardian", "the Steward", of the Earth. ${ }^{47}$ This is a linguistic, embodied extension, the attempted "transference of forms of intelligibility" non-intelligible relations like the decision-making capacity of a few humans and the total nuclear winter of the entire globe.

It is not merely a case of identifying kinds and pairs of subjects, but of setting up a definitive zone where the oddities fall in such a way as to suggest both an outside undesirable limit and an inside desirable possibility. In the field of sexuality, Foucault identified "the hysterical woman", "the masturbating child", "the incestuous relations" and "the pervert". Each of these corresponds to an allegedly pervasive persona in a zone of pathological sexual relations. For each of these there is an intended normal, non-pathological subject which can be imagined or described against these pathological personages, even if he or she cannot actually be located in medical practice or census-taking. The normal subject falls is so adequately within the field of sexuality that

During the gulf war, the language of honorary and dishonorable conduct was used to distinguish the West from Baghdad, and to justify opposition to Saddam Hussein. Globe and Mail (Nov. 15 $5^{\text {th }}$ 1997): A1;A 15. See also "The Man in Iraq." The Economist (Nov. 8th, 1997).

47

Arun Makhijani and Hisham Zerrifi, "The Stewardship Smokescreen." The Bulletin of the Atomic Scientists 52:5 (Sept/Oct. 1996):22.

48

Michel Foucault. The Birth of the Clinic. Trans. A.M. Sheridan Smith. New York: Vintage, 1994:105. 
they define it by their numbers and general characteristics, not their unusual qualities.

The normal subject always exemplifies mental, social and physical health. In each

domain, among its attributes are rationality, sociability, efficiency and self-discipline. It is

not surprising that the normal modern subject exemplifies the key principles of modern

economics, philosophy and politics.

This normal subject is a "founding" or "sovereign" subject. Founding subjects are

also called "figures of control", the one who,

...directly animates with his intentions the empty forms of language with his objectives; it is he who in moving through the density and inertia of empty things grasps by intuition the meaning lying deposited within them... he indicates the field of meanings...he has at his disposal signs, marks, traces, letters. ${ }^{49}$

The pool of domain-specific subjectivities evolves over time as new personae are added ${ }^{\text {so }}$.

Others become obsolete or mutate into new variants. The medical terms "syndrome" and "disorder" usually indicate an evolution of a very recent "type", as in "Attention Deficit Disorder" and "Learning Disorders" (pathological child-state), or "Gifted Children", (abnormal child-state). Freud's "Hysterical Woman" seems to have mutated into

Michel Foucault, "The Discourse on Language." in The Archeology of Knowledge. Trans. A. M. Sheridan Smith. New York: Pantheon, 1972:227-8.

50

Jan Wong's "China: Inside the Closet. Gays Find a Space Between Ignorance and Intolerance", The Globe and Mail, (Toronto: November 14th, 1992, pp. A 1;A 14.) gives an example of the "adding" of "gay men" to contemporary Chinese culture. She describes how an absence of an overtly "gay public culture" in contemporary China has meant that the development of clearly gay personae has been slower and (where present) more ambiguous than that same culture in, for instance, Montreal. The "pervert" has not been described and set at the outer limits of sexuality such that non-perverse sexual relations between men and woman can be clearly differentiated both by gay men (as gay identity) and by law officials (as criminal behavior). 
Epstein-Barr syndrome, Premenstrual Syndrome, and Hysterical Blindness, all

female-specific. ${ }^{\text {s1 }}$ Particular features sketch the kinds of subjects who fall within these conditions, dictating,

...the qualifications which must be possessed by that individual who speaks, who occupies such-and-such a position and formulate such-and-such a type of statement....who defines the gestures, behaviours, circumstances, and the whole set of signs...the particular properties and the stipulated roles of the speaking subjects. ${ }^{32}$

The evolution of types is sometimes the result of a subjectivity from one domain being drawn into and applied to another domain. To be moved and detected requires that the subject has, attached to him or her, a set of techniques of detection, a set of distinct signs, which can be applied for new purposes. In I, Pierre Rivière... Foucault reveals how the "insane madman" a subject of psychiatry indicated by monomania (delusions, "a dour fanatic", unsociable repetitive gestures, a "bilious-melancholic temperament"ss) can be diverted in order to make his appearance in the courts as "the evil madman", a criminal subject ('taciturn...an ardent, cruel and violent imagination, unrepentant yet fully cognizant of his deeds"). The parricide committed by young Pierre Rivière is: ...an affair, an event that provided the intersection of discourses that

J. Ussher. Women's Madness: Misogyny or Mental Illness. New York: Harvester Wheatsheaf, 1991.

Michel Foucault, "The Order of Discourse." Trans. Cyril Welch. (1999):16 private translation.

Michel Foucault I, Pierre Rivière.... Trans. Frank Jellinek. New York: Pantheon, 1995:122. 
differed in origin, form, organization, and function....s

In the court and medical documents describing -- or rather, claiming -- the parricide

Rivière as one kind of thing or another we can read the tensions and counter-forces

between psychiatry and justice. The deposition of characteristics of Pierre Rivière as $a$

Parricidal Maniac, is, according to Foucault, the map of,

...the way in which a particular kind of knowledge (e.g. medicine, psychiatry, psychology) is formed and acts in relation to institutions and the roles prescribed in them (e.g., the law with respect to the expert, the accused, the criminally insane, and so on.) $)^{s s}$

The equal capacities of the justice and medical systems to identify him as mad and as

criminal, results in a perfect stalemate of judgement approved by the King of France:

In view of the doctors' conflicting reports and the various material facts, some of which disclose a considerable power of reasoning and calculation, whereas others appear to establish the perversion not only of his moral faculties but also of the functions of his discernment, I myself feel such grave doubts about the convicted man's mental state that I am wholly unable to conclude either that the [death] sentence should be carried out or that he should be excused from all punishment.sn

Foucault's history of Rivière suggests that while subject positions serve particular normative functions upon a particular domain, the arbitrariness of these positions

(ibid:xi).

(ibid:xi).

56

(ibid: 168-9). 
and the work that they do to forward judgements can be exposed when the subject is taken across discursive boundaries.

The first general function, then, of subjectivity is to create positions within a discursive field: persona. In general, what this involves is that those positions are named; that a particular set of techniques for gathering information about or operating from that position is engendered; those positions are given a set of signs which identify them as a distinct type, mark the types as negative or positive; that persons are ranked (juridically, medically, aesthetically) according to their distance from or proximity to, the ideal and the anti-ideal. A few abstract features of "persona" regardless of which discursive field they appear on, and function on, include: they represent an ideal or an accurate "type", where that "type" is a class or species of persons, they are visible or can be made visible to a culture (in language, in art, in scientific modeling, in media), they are capable of receiving, taking up, and displaying evolving sets of characteristics (which might include being divested of prior characteristics), they are widely recognizable as a type, they have capabilities which are subsequent to this recognition as a type.

I will now identify the personages of the domain of property.

The production of sovereign subjects of tangible property. Their significations and techniques for identification or attribution

Title by Descent, Title by Purchase, Title by Escheat, Title by Occupancy, Title by Prescription, Title by Forfeiture, Title by Alienation, 
The field of property has its own sovereign, foundational subjects. The founding subjects arise in tandem with a story about the origins of property and evolve as the justifications for property change. When the source of property is God, the subjects of property have a theological claim in their known or declared relation to God. In the medieval story, that relation lay in a family bloodline; a true owner's identity lay in their blood type. The heads of kingdoms and their rightful heirs -- "Fathers of families as were the lineall heires of those families whereof Kings did originally come"s* owners, while the bastards and usurpers could not. Those without land and means are, at best, manor-fixed land-holders (vassals and fiefs) where holding was subject to conditions rather than absolute. ${ }^{.9}$ Those without land were thieves and (thus) godless men. With the rise of the democratic political state in 17th-century Europe and its spread over the next two hundred years to the Colonies, came the rise of private property. This major

William Blackstone. Commentaries on the Laws of England. Chicago and London: University of Chicago Press, 1979.

Extract from Speech of 1609 of James I, quoted in The Great Political Theories, Vol. 1. Ed. Michael Curtis. New York: Avon, 1981:316.

59

(ibid:158). Landholding among German freemen was conditional upon work: "A freeman, like the nineteenth-century American homesteader, took possession of a tract of land by clearing it, building a house and barns, and dividing the land into fields for the grazing of animals and the growing of crops. His initial work established his claim to continued use." Eugene Hargrove, Foundations of Environmental Ethics. Englewood Cliffs, N.J.: Prentice-Hall, 1989:56. 
shift in what property meant and how it could come to have relations with the average man, would not have been possible without a new figure of ownership to simultaneously animate and vindicate it.

The ideal characteristics around which modern (private) property took shape were: Man the Worker, Man the Producer, Man the Provider. This was an individual and yet a member of a group, both a private one (a family) and a public one (a geographical, religious or economic community). The investment of labor and capital in land did not only return of capital but an increase in status. ${ }^{\circ 0}$ Moreover, he was an exemplar of a universal type: "humanity". This was also an adult male of European descent.

The two personae which best exemplified these modern ideals (and often are still considered the best expressions) were the farmer and the merchant. The farmer model overshadows the merchant model as the economy shifts from feudalism through mercantilism to capitalism. Farming is an honorable relation of ownership because it is seen to be unique in its capacity to express significant human values. Even critics of modern agribusiness manage to salvage and honor "the family farmer" and the virtues of "a farming life"." The farmer claims his property title by work and by natural right rather than blood. The subjects of property are constituted through particular techniques of labor

Peter J. Hugill, "Home and Class among American Landed Elite." The Power of Place: Bringing Together Geographical and Sociological Imaginations. Eds. John A. Agnew and James Duncan. Boston: Unwin Hyman, 1989:66-7.

61

See for instance: Donald Worster, "Good Farming and the Public Good." Meeting the Expectations of the Land. Wes Jackson, Wendell Berry and Bruce Coleman, eds. San Francisco: North Point Press, 1984:31-41. 
and exercise of rights, and are recognizable (as are their rightful belongings recognized as theirs) through particular signs of labor and right.

In Locke's "Labor Theory of Value" we find a fully elaborated picture of the farmer as the ideal figure of ownership. While God gave the World to Men in common, he also gave man reason and the means of appropriation to make use of this gift for his convenience, support and comfort (V:26). Each Man has a natural, exclusive and absolute property in his own person (V:27). It is only through the work of that body on other parts of unowned Nature, through the transformation of raw Nature into usable goods (amassed or altered) that property greater than ones own body is annexed to an individual. Private property rights are intended to reward industriousness and to secure and safeguard the fruits of efforts. Clearly, a rightful owner must be, first of all, industrious. Second, an owner must have fruits of his efforts which require safeguarding. Industriousness distinguishes the owner from those who have shown little interest in using God's gift for their greater Support and Comfort, and therefore may claim, at most, mere physical possession. In Locke's view, and many who followed him, the lazy are also unreasonable, since natural reason suggests that it would be in our interests to be industrious and acquisitive, both as concerns our private and our public well-being. ${ }^{.2}$ This equating of rationality and efficiency is seen throughout modern society. ${ }^{63}$ Rational choices are Press, 1962.

63

Emin Fuat Keyman, "Mapping the Concept of Modern: Three Discursive Positions of Epistemology and the Uniqueness of Western Capitalism." Department of Political Science, Carleton University Occasional 
self-protective since they forge social ties of mutual support and dependence - civil community. The values of efficiency, sociability and rationality are all found in the farmer.

Private property is the result of labor, but not just any old exertions in any old direction: it is the result of intentional labors directed toward the extraction of resources and the efficient (i.e. organized, stable, effective) production of culturally consumable goods. This kind of labor, according to Locke, produces results which are superior in quantity and value to the products of "random", "wild" and "spontaneous" efforts. The functional category of "use" becomes a normative category, dividing good users as owners from bad users as thieves, squatters, free-riders, jerry-riggers, pirates,

Unlawful use is equivalent to theft and can deprive rightful users of significant commercial benefit.".

Farming leads to positive utility. Farming efforts increase value in the world, since "Bread is worth more than Acorns, Wine than Water and Cloth or Silk than Leaves, Skins or Moss." (V:37,42) Moreover, farming is socially-minded since the positive-sum game, (especially with the advent of monetary and market exchange mechanisms), promises to increase general not just individual utilities. The primary good of farming lies in its utility: farmers, then, are rightful subjects of property insofar as they exhibit a desirable,

Papers 16 (April 1988): 1-46.

64

Nicholson (1983:26); See Vega (1990) and Schaffer (1990) on the U.S. generated "Global Priority Watch List" of suspect i.e. non-cooperating countries. 
pragmatic form of moral rationality. ${ }^{\text {ss }}$ They are good users, i.e. owners.

In order to make a claim about rightful belonging there must be techniques available to this industrious individual to demonstrate a difference in quantity and quality of his products, to affirm and mark him as that user. Key "techniques" are the moral, customary or juridical relations between the claimant and a body (tribe, society or state) which will enforce a property claim. ${ }^{66}$ This body is the same body which stands to gain the most from the privatization of the commons in terms of having access to better and more products through the market system.

In order to enforce a claim there must be proof for it. The proof for this claim must be traceable to an industriousness on the part of this individual. The best evidence of industriousness is any evidence that can be shown for it: one may be industrious and yet consume whatever one gathers or makes, but if one can show a ready-at-hand surplus, a residue, an overflow, a stockpile, if one is in possession of a possession, this confirms effort in a way which a claim in the absence of material evidence does not. The thing called the possession points toward the one who is in possession of it, as the owner, Though the Water running in the Fountain be every ones, yet who can

To contrast, Michael Hardt, "Mercantilist Bargaining and the Crisis in the Multilateral Trade System: Finding a Balance between Domestic and Foreign Trade Policy." Occasional Papers in International Trade Law and Policy /Center for Trade Policy and Law 4 (1989): 1-39 suggests that agrarian from developing countries are "a drag on the system" [G.A.T.T. negotiations] because their understanding of agricultural economics "has, at best, a fragile intellectual foundation", and that they prefer to put the values of agriculture "in theological terms" rather than in terms of "political will... and pragmatic bargaining."(33).

66

C.B. Macpherson. Property. Toronto: University of Toronto Press, 1978:3. 
doubt, but that in the Pitcher is his only who drew it out? (5:29)

There is a relationship that is respected or inferred between the products and the owner; there is a manner in which the claim and the items (the "text" of property) "points to this 'figure' that, at least in appearance, is outside it and antecedes it." 67

Any stable artifacts in which, upon which, or via which labor could be written, inferred and somehow counted ("possession ratified by conventions")"ss were ideal. Barns with hay in them, acres with a certain number of stakes, lengths of barbed wire, a measured enclosure, bushels of fruit, sweat of the brow, provisions in a secure, unmovable place, bank ledgers, land registry records, money. Having any or all of these in one's possession confirmed or at least strongly suggested some sort of previous effort. Rousseau recognized the power of the artifact and the mutually complicit claims which could be generated from it: "The first person who, having fenced off a plot of ground, took it into his head to say this is mine and found people simple enough to believe him, was the true founder of civil society." ${ }^{\prime 9}$ Rousseau claims that without property there would be no civil society. Tangible "property" certainly is significant to the possibility of Pantheon, 1984:101.

Michel Foucault, “What is an Author?" The Foucault Reader. Ed. Paul Rabinow. New York:

68

Jeremy Waldron, "The Humean Theory of Property." Social Philosphy and Policy $11: 2$ (1994):90.

69

Jean-Jacques Rousseau. Discourse on the Origins and the Foundations of Inequality among Men [1755] in The First and Second Discourses. Ed. Roger D. Masters. New York: St. Martin's Press, $1964: 141-42$. 
civil society insofar as it lends itself as a kind of surface of inscription upon which such things crucial to civil society as fair distribution, names, ratios between labor and payment, and order can be marked.

Whether these possessions or the claims to them were the result of fraud, theft or "honest labors", could only be determined by a close historical and legal investigation of how one came to hold the land (by Natural Right or by Seizure), or some sort of witness to the labor itself. In the case of the farmer, his efforts are almost entirely visible as he is. "The small farmer is not usually an absentee owner...his productive use is joined to its usufruct."70 A farmer's possessions (barns, land and its products) have the least tenuous relations to his location and his efforts because of the scale and visibility of farming.

...the typical workman was not a laborer but a peasant farmer or small master, who could point to the strips which he had ploughed or the cloth which he had woven...."

Among the kinds of persons claiming private property, the farmer is the least suspicious in terms of this burden of proof. As a result, the farmer himself takes on an ideal subjectivity in the domain of property, a moral and an epistemic rather than simply a useful role. "Contract theorists came to consider their theories as logical or moral rather 
than as historical."'r Of the expansion of the Americas under Jefferson and the role of the farmer, that,

[Jefferson] stopped trying to justify his position championing the rights of Americans to small freehold farmsteads...in terms of historical precedents and instead began speaking in moral terms, claiming that small, independent landholders were the most virtuous citizens and state could ever hope to have."

Jefferson himself wrote,

Cultivators of the earth are the most valuable citizens. They are the most vigorous, the most independent, the most virtuous, and they are tied to their country and wedded to its liberty and interests by the most lasting bands. ${ }^{74}$

The kind of industriousness which definitively identifies an owner is unilateral, exclusive and non-mobilized acquisitiveness. This in effect limits who can assume this subject function to male property owners. Having possessions signaled efficiency, rationality and virtue in the possessors. It is the signs of possession -- specifically the inequality of their power to point to certain persons -- and not the formal rights to be a possessor articulated by Locke and Mill and Hobbes, which play the most significant part in forming the subjects of property. "The being of the signs which are taken as neutral, yet which are

Melissa A. Butler, "Early Liberal Roots of Feminism: John Locke and the Attack on Patriarchy." Feminist Interpretations and Political Theory. Eds. Mary Lyndon Shanley and Carole Pateman.. Penn State University Press, 1991:78.

73

Hargrove (1989:62).

74

Jefferson to John Jay, “A Summary View of the Rights of British America" (August 23, 1758) in Portable Jefferson. Ed. Merril D. Peterson. New York: Viking, 1975:384. 
constitutive."7s Jean Bethke Elshtain insists that we must pay attention to the way the actual physical realities of men and women coming to the promises of liberal democracy played a major role in the degree to which the promises of that political system were actualized in the lives of men relative to the lives of women. They played a role because of the way that prior possession signals an owner type. Elshtain claims that this is how we can account for the present gendered disparities in "the distribution of goods and services and in the concrete allocation of economic and social power"76 even though, under liberalism, women "could earn, make contracts and own property"." Elshtain writes,

Locke's abstract grant of property rights is in some important ways tendentious in a social situation in which the female portion of the population is propertyless. If past history is patriarchal -- in this Locke agrees -- and the chief motive for the formation of civil society is the preservation of property...it is difficult to see how women can emerge, simply by a grant of formal rights, from a condition of propertylessness and subjection to one of public parity. ${ }^{7 *}$

Women tended not to be owners because they tended not to be in possession of proof of

Michel Foucault. Foucault Live. Ed. Sylvère Lotringer. Trans. Lysa Hochroth and John Johnson. New York: Semiotext(e), 1996:17.

76

Jean Bethke Elshtain. Public Man, Private Woman. Princeton: Princeton University Press, 198 1:122.

77

(ibid: 121).

78

(ibid: 122). 
past or potential ownership. This remains true today: those who cannot demonstrate adequate proof of prior ownership are less likely to be recognized as a potential future owner than others who can provide such proof, regardless of the circumstances surrounding their being in possession of that proof. This "proof" resides not only in papers or bank drafts or proof of payment, but in the kind of persona which they embody or do not embody. I have owned my own house for twelve years but each time I renew my mortgage, I am required to get my father's co-signature on the terms. He was required as a guarantor from the outset even though I was in full possession of a down payment and had a rental income organized to cover all subsequent payments. Moreover, deferring to his "prior ownership" status completely eclipses my stepmother, who is as much an owner of everything he owns as he is. I have made each payment since then: he has no role in this ownership other than symbolic. When I go to a bank to renew, each time the same thing happens: the bank manager does not "figure out" that the person sitting waiting at his or her office is the same person who has an appointment with him or her. (It takes about twenty minutes before they ask me if they can help me, then they act irritated at me because the appointment starts late....) They always call me "Mrs." and ask me when my husband will be joining us? Once everything is "cleared up" and we talk about the questions I've come with, and I make my choices, we send off the paperwork for my Dad to sign. This last move falsely confirms his role as critical in the procuring of property by women. His is the persona of owner, mine is not. This is a gendered persona. Relatedly, women also tended not be owners because the products of their labors were seen to contribute to the private rather than the public good, or, their labors were not 
considered the same kinds of bases for ownership claims as the labors of their menfolk. The proper name of a woman, often changing in marriage, would not serve her in the same way that a signature of the family name would affirm a man's connection to a piece of land, particular community, ${ }^{79}$ and a long line of workers.

Moreover, in some parts of the world, women themselves count among the kinds of things that one can own, or at the very least, claim guardianship over. This is to say that relations between possession, possessing and a potential possessor are not simple. Persons having possessions yet without demonstrable individual acquisitiveness (i.e incorrect amount) tended to be seen as lazy, unprogressive, heathenish. We saw this in the last chapter concerning the encounter of the European nations with Amerindian and Polynesian tribes who practiced potlatch or migratory land-use patterns. Persons showing acquisitiveness but for the "wrong" kinds of possessions tend to be seen as having some kind of personality disorder. ${ }^{\text {so }}$ Persons showing little interest in honoring the exclusive entitlement claims of another are trespassers and thieves, even where the ones upon whom they are trespassing or from whom they are taking, were themselves at one point trespassers or thieves.

The difference, then, is whether one has a strong enough group to back and protect an entitlement claim, or whether one is a minority, an outsider, an anti-persona.

A male friend recently remarked, of his trip with his mother back to Scotland, to the village of his ancestors: "In one small graveyard there were gravestones with my exact name - John Alexander Crawford - on them that went back every other generation for over two hundred years!"

80

See Sigmund Freud's essay on fetishes in "On Sexuality." The Standard Edition of the Complete Psychological Works of Sigmund Freud, Volume 21. Ed. James Strachey. London: Hogarth Press, 1943. 
Persons having systems of property which employed different techniques of acquisition and different systems for confirmation of rights of use than those used by farmers signaled those persons not as owners but as its antithesis: children, owned, thieves, heathen. Any inefficiency, laziness, irrationality, anti-sociality and lack of virtuous character disqualifies the owner function. There is a distinct set of signs of ownership, there exists a general willingness to recognize these, and the means (legal, moral, communal) to enforce their recognition. These three functions are indispensible when cultures interact. "Violent conflict is especially likely to occur on the boundary between cultures, where people with very different ways of viewing the world interact." According to James Tully,

One of the leading problems of political theory from Hugo Grotius and Thomas Hobbes to Adam Smith and Immanuel Kant was to justify the establishment of European systems of property in North America in the face of the presence of "Indian Nations"...2

The founding subject of modern property in the figure of the farmer, the owner function, endowed as he was with a set of values, created by and supported by adjacent domains of morality, economics and politics, was (and to some extent still is) the key to that justification. The owner function as a subject of property is a "mode of circulation,

81

Friedman (1984:7).

82

James Tully, “Aboriginal Property and Western Theory: Recovering a Middle Ground." Social Philosophy and Policy $11: 2$ (Summer 1994): 156. 
valorization attribution and appropriation" ${ }^{13}$ which makes the discourse of property possible and keeps it in motion. The farmer as the ideal owner is the founding subject of modern, private property, constituted by and constituting a power/knowledge framework which recognizes and justifies claims of ownership based upon the resemblance of the claimant to that ideal. It also excludes or misrecognizes other claimants as non-owners based upon their dissimilarity or lack of expression of those ideals. What is also significant here is that with this subject function, reason and madness appear in the domain of property. These two attributes anchor the moral to the economic in a kind of being, the same being who animates the moral and economic arguments I outlined at the beginning of this chapter. A madness or irrationality of property-relations is enforced through the tactics of exclusion and inclusion, yet the regulatory body is not a body of experts but the body of one's equals: the civic society itself. To paraphrase Foucault, the manner in which the modes of circulation of property are articulated according to social relationships can be more readily understood in the activity of the owner function and in its modifications than in the themes or concepts -- like progress or privacy -- that this discourse sets in motion. ${ }^{\text {ks }}$

Perhaps this sovereign subject of tangible property seems benign and anachronistic even if appropriate to the historical developments of private property as 
they arose in the European colonies. The small farmer as the worker, the work investment legitimating claims to ownership, rightful ownership inhering in claims of honest labor recognizable and recognized by one's peers or community, the position of provider to a family and to a community, the particular civic virtues and values of recognizing and uphold these relations as relations of rightful property, all endow an owner function with the proper classificatory role that that function performs in the discourse of property.

This figure lurks behind positions regarding property and plays a normative role in that it garners approbation for forms of property through the approbation that the figure itself draws. This owner effect as a function appears clearly in several ways. For instance, the work ethic and the virtuous good of the farmer obscures the many ways in which the environment, human beings and even communities are threatened, abused, devalued and sometimes destroyed by modern land tenure practices. The small, family farm is not exempt altogether from these charges even though they might be carrying out atrocities at much smaller scale. Why has there been a relative lack of sexual assault support services for rural women, and a general resistance to address this widespread problem?ss I think that partly it has to do with the image of wholesomeness and virtue that a farmer carries.

The owner effect obscures the demographics where, in fact, the vast majority of real estate in North America is held by a fraction of the overall population: that is, the good of land is not at all distributed in a way that resembles that suggested by the Equality, Final Report." Ottawa: Minister of Supply and Services, 1993. 
small-land-owner in his-community image. Wealth in land has been uncoupled from the wealth of those who work the plots, and the value of land has been largely uncoupled from the agricultural profits it is capable of producing. It is not that capitalism is a consequence of the "owner-function". It is that he prevalence of a mode of conceiving the production of agricultural goods which is symbolically informed by the owner-function, (just like my mortgage deals are symbolically informed by the same in the figure of a father-owner), obscures a correct view of the situation. Emotionally and imaginatively, we are protected from considering the vast region of cultural production where things are being made by no one in particular, i.e. are factory made. Peter Singer has argued forcefully that just such a false image prevents us all from knowing and responding with compassion and justice to the misery and stupidity of factory farm production. ${ }^{\mathrm{x}}$ Lastly, this particular owner effect continues to contribute to the political climate which has yet to resolve peacefully and respectfully, Aboriginal land claims.

When we look at intellectual property we will see the strong role that the owner function which I have sketched in this section also plays as role there, yet in combination with the author/genius function.

The Sovereign Subjects of Intangible Property: Signification and Techniques for Identification or Attribution

Who owns a song and its numerous copies in numerous media? Who owns manufactured life forms, or small parts of humans? What are the property relations

Peter Singer, "Down on the Factory Farm." Animal Liberation. New York: Avon-Hearst, 1991. 
between the investment of time, capital or reputation and the production of public goods such as books, genetic marker tests, and on-line inventions? Most of the debate on intellectual property centers on "larger" moral and political justifications such as, "is it efficient and useful to patent seed presently being used by Indian farmers", "does Metallica have a case against MP3.com for enabling free music downloading off the Net?" The advent of cyberspace and the technical possibilities of genetic patenting has meant that these kinds of questions are being revisited and revised in ways that have not yet been seen.

In this section, I want to discuss the sovereign subject that animates these questions. There is a second subject-function which animates the adjacent domain of intangible property. That subject is the Author/Genius function. The owner-function that we encountered in the previous section on tangible property is also part of this field, tying an individual to his or her ideas as an owner, insofar as thinking is considered a form of individual effort, or work. The author-function plays the role of setting norms and influencing intellectual property debates, even in cases when, as was the case with the "farmer", there is no real, single, actual "author" or "genius" to whom this norm could be traced. An obvious example of this is holy texts. The sovereign subject can be identified by interpolation from aspects of these debates: specific moral harm that is presumed to ensue in the case of infraction, specific kinds of alienation or reverence that an owner of ideas is entitled to. I will use Foucault's "What is an Author" to make more explicit what the author/genius-function is, and how it is operating in the domain of intellectual property not only as a relative but an absolute norm. 
There is an historical evolution to the emergence of a sovereign subject for intellectual property. With the rise of literacy, the expansion of secular scientific research and the spread of printing technologies, another set of ownership relations needed to be worked out. This set of relations required another kind of subject of ownership to speak as the rightful, attributable owner of scientific and artistic creative works, of books, designs, inventions, paintings, musical scores, and mathematical theories. Legal and moral relations of intellectual property also need to be co-ordinated globally in different ways than they were before the advent of electronic communication. International cooperation for the issuance and protection of intellectual property rights is currently the domain of the World Intellectual Property Organization (WIPO), a unit of the United Nations. WIPO administers previous treaties on I.P. including the Berne Convention for Protection of Literary and Artistic Works (1886), the Paris Convention for the Protection of Industrial Property (1971) which is largely concerned with patents, and the Rome Convention (1964) which pertains to film, sound recording, broadcasting. Countries also have their own expression and adaptation of these conventions for domestic policy.

These debates and policies are dependent upon a set of assumptions about what kinds of subjects can be said to actually be owners of these various forms of intellectual property. Among those is the assumption that this kind of subject bears an exclusive relation to an actual person. There is a correlation between identifying the ontological and characteristic features of these founding subjects and identifying the ontologies and real features of the kinds of things that can or cannot be owned ("attract or repel copyright"): it is the meshing of these relations which make certain persons creators and others users. 
"It is part of the metaphysical grammar of things that objects require subjects." "ar Even where intellectual property is not seeking legal justification or clarification in a given debate, but where its terms (legal and historical) are simply being described (for the sake of information, for the sake of compliance), the figure of ownership and non-ownership to whom these reports allude, "carry" and engender normative effects. The question of the status of the subject on intangible property, then, is primary, as this subject acts as a presupposition upon which subsequent debate is based.

I will first look at some of the general features common to different forms of intellectual property, especially at its general justifications and its present policing practices. This section is not comprehensive, but it does provide background and an overview of some key aspects of intellectual property which highlight the subject "behind" it.

\section{A). Some Background on Patent and Copvright}

Current conceptions of intellectual property were first developed in Europe between the 15 th and 17 th century. ${ }^{\mathrm{xx}}$ There are different forms of intellectual property: copyright, patent, trade secrets, service marks ${ }^{k y}$ and trademark. Each of these pertains to

Sandra Harding, "Rethinking Standpoint Epistemology." Feminist Epistemologies. Ed. Linda Alcoff and Elizabeth Potter. New York: Routledge, 1993:64.

88

Indigenous Knowledge and Development Monitor, 1:3 (1993):35.

89

Nicholson (1983:19). 
slightly different kinds of property in ideas and different means of

production/transmission. Patent applies largely to technical innovations and processes via application (which involves a filing fee) to a regulating body like the U.S. Patent and Trademark Office. The developer of the idea (a natural or an artificial person ${ }^{\circ 0}$ ) discloses a detailed description of the product, ${ }^{91}$ including a description of how the innovation can be applied, an account of its distinctness, a deposit of some materials for storage for 35 years, and an outline of the technical scope of the rights granted, in exchange for a license of a specific term which certifies the product as privately owned and grants the patent holder monopoly privileges on it. The patent holder must also pay a maintenance and issuing fee upon issue of a patent.

The three conditions which must be demonstrated, satisfactorily, to a patent officer in order to be granted patent (ownership) rights are: 1) utility (the patent must be for a useful application of an idea, not the idea itself); 2) novelty (the patent must not be for something previously made or done - checked in reference to existing patents in the patent archives not to things in the world at large - or be too similar to another patent pending); 3) non-obviousness (the patent must be for something which would require greater than common sense thinking and ordinary skill in the area at the time of

90

Macpherson (1978:6).

91

Trade secrecy concerns have meant that the degree of information, and the transparency of the idea in the results is not always consistently divulged. Petty patents or utility patents are "mini" patents which have a shorter term, lesser protection but less stringent regarding conditions of disclosure. (McDonald, 1999). 
invention, to devise and design). "The burden of proof is on the examiner to show that an application must be rejected." ${ }^{2}$

One other pertinent fact about patent has to do with what is called "compulsory license". Compulsory licence provisions are contained in intellectual property laws and give overseeing bodies the right to revoke and reassign patent monopolies in the event that the issuee is not appearing to make good on his or her promise to develop a product from the idea. The original owner is sanctioned since "failing in his obligation to work the protected invention"93 constitutes an abuse of his property. This failing might mean not developing a product at all from an idea or a formula or it could include making the product available in too narrow a distribution or at too high a price. Where a second party can demonstrate an interest in and the means to more aggressively develop a product or a service, the compulsory licensing system will transfer the idea to their property with some compensation payment to the original issuee.

The rationale offered for this form of intellectual property (patent) is two-fold: First, that the inventor should be rewarded economically and symbolically for his or her specific contribution. Second, and closely related, that term protection is a necessary component toward encouraging and sustaining research and development. Companies having invested time, energy and capital in technically-intensive research would not

Gleick (2000:48). 
undertake these projects if there was no means by which they could exclude imitators (with zero overheard and start-up costs) from gaining from their work. In short, the advantage and competitiveness of patent licencing is crucial to economic performance and growth. It is also crucial to the fostering and encouragement of genius. It is so crucial as to allow the confiscation of private property under the rubric of waste, sloth, squandering, speculation.

Copyright is a different area of intellectual property than invention. Copyright applies to all original literary, dramatic, musical, artistic works and sound recordings. Unlike patent, copyright is automatic upon the production of an original work. Examples of things which attract copyright are: books, music, sculpture, charts, maps, photographs, films, records, audio and video tape. Recently it has been extended to: protection of computer software, ${ }^{4+}$ timing of release and rental of works, internet domain names, live performance, cable transmissions (including broadcast and network communications), and even Internet browsing.

Ideas themselves cannot be "copyrighted". Mental processes and abstract intellectual concepts are "manifestations of nature, free to all men and reserved exclusively to none", so that they can serve as the basic tools of scientific and Convention." (Jacobs, 1994: fn.5). 
technological work for all.95 Traditionally, only the physical manifestation of the ideas, ${ }^{*}$ the actual visible or audible works themselves, were copyrightable. Copyright law is in this sense an extension of property law, like patent law, which is grounded in "the physical plane".

Copyright is a convention which legally and morally identifies an owner of these works, which is some cases is the publisher and not the writer. Copyright gives the creator absolute control over the subsequent reproduction of her work, including "artistic reworkings" or knockoffs from the original material. The copyright holder has exclusive unlimited right of copy to herself ${ }^{77}$ to present the work in public, to adapt it to other media, and to authorize communication, adaptation and usage of the work by others. In some provisions, copyright holders have right of first disclosure and right of withdrawal. Copyright then, just like property in land, entails a right of exclusive use and/or control of use. The form that this takes with respect to the products of the mind is that a copyright holder can take legal action against infringement (unlicenced, unacknowledged, or unacceptable reproduction).

Gleick (2000:48).

"The Impact of New Technologies on Copyright Law." brief to The Standing Committee on Canadian Heritage. Peter Sandmark, National Coordinator, Independent Film and Video Alliance, 1996. (http://www.culturenet.ca/ifva/pub/copyright.htmi).

97

Brenda Wilson and Peter Burpee, "Understanding Copyright: A Practical Guide for the Social Sciences and the Humanities." Social Science Federation of Canada and the Canadian Federation for the Humanities, 1990. Addenda by B. Katz, Chief Librarian. University of Guelph. 
Historically copyright infringement in the form of the production of pirate copies of books, records, maps, plans, diagrams, engravings, movies $T$-shirts and so on have always involved a certain amount of investment and occupation of physical space, leading to the possibility of discovery. ${ }^{98}$

There is one notable exception to the rights ensuring exclusive use: "fair dealing guidelines". Recognizing that copyrighted works should be available to the public for certain prescribed kinds of uses at an unrestricted or fairly unrestricted basis, certain kinds of published material are considered exempt from copyright (the Globe and Mail is one example) or, there are arrangements between the Copyright Board and educational facilities like public libraries and universities whereby special copyright terms $(\%$ of a book which may be copied for a coursepack, etc.) are administered and paid for by those institutions in order to maximize access for its clientele. Fair dealing guidelines are not easy to police, since "the onus is on the Crown to disprove fair dealing...i.e. to show that a given work is not copied routinely in small portions for educational uses." ${ }^{\text {"we }}$ Moreover, stipulations of fair dealing here, as is the case with patent application, involve discerning the actual intention behind the use or application, which is never easy to prove.

What is at stake in the issue of intellectual property infringement -- how and why rights in property to ideas have been disrespected-- are two claims about two very different kind of harm: one involving money/utility, and the other having to do with damage to the personal integrity of the person behind the work: the author or the inventor.

(ibid: 14).

Christopher Clark, "Legal Update: Intellectual Property." Canadian Lawyer (February 1995):43-44. 
Some concerns focus on the loss of economic goods and others on the loss of, or threat to, what might be more appropriately named "moral goods". ${ }^{100}$ The former are derived from the owner-function and its set of features and ontological assumptions; while the latter kind of harm is unique to the author-genius function and its set of features and assumptions.

\section{B). The set of economic-utility assumptions, their sovereign subject}

With respect to damage as compromised utility, the claim here, as was explicit with patent protection, is that an author or a map-maker, having invested time, money and energy into the production of, say, a textbook, has a right to recoup his or her investments through mechanisms (like CanCopy) which set user fees (for photocopying) and redistributes those fees to the authors whose works are being used. In a very reasonable sense, we should think of the life of a writer or a painter as a kind of job, and thus consider artists as normal persons, who require monetary compensation if they are to continue to be able to do those activities, to survive and possibly even to make a decent living from these activities. If original work is copied freely or screened in public, without overhead or fee by a 2 nd party, and this 2 nd party profits in any way from this (enjoyment, economic, status) they are committing a crime. They are profiting, illegally, having done nothing more than copy (not create) the property of another. They have "pirated" a work. They are committing very real crimes of theft or fraud. govemment deems politically offensive. John Lorinc, Globe and Mail, Oct. 29th, 1996:D1. 
Persons found guilty of copyright infringement such as the offence of unauthorized public performance, by way of summary conviction is subject to a maximum fine of $\$ 25,000.00$ or six months imprisonment or both, or by way of indictment to a maximum fine of $\$ 1$ million or to imprisonment for a term not exceeding 5 years or to both. This activity also constitutes a civil infringement. ${ }^{101}$

The second sense in which copyright protection is seen as necessary economically has to do with the assumption that, in general, artistic innovation is good for economic growth and that this general kind of innovation will not take place -- there will be lack of incentive or even disincentive -- if there are insufficient economic rewards secured for, and promised to, creative persons. A related problem is the classic "crime doesn't pay" line. In the domain of intellectual property, skimming off freebies like software from the Net (not "shareware") changes the internally regulated ratios of users:producers:technical support staff. You might get free software, but you will probably need, at some point, technical support to work it properly. It might not be available, in both a legal and an actual way, if you have not gone through proper channels to get a hold of that software. This is not unlike having a stolen Rembrandt that you can't unload at Sotheby's.

These three arguments-- the argument about work and its due compensation, the argument that initiative requires security of outcome and the argument that it is really not in one's best interest to dodge the appropriate channels of appropriation were encountered among the arguments in favor of, and also against, private property in land. Office brochure. Distinctions made between intentional and unintentional misuse, in order to determine the full nature of the crime. 
As I showed there, whether these economic-utilitarian arguments are compelling or not will depend upon how one interprets any or all of the central principles, how and what one counts. Related to this was the fact that ontological assumptions about the nature of work, the source of values, the relationship between efficiency and overall utility, etc. were built into any one view and it was these which gave the arguments their strength.

\section{Ontological presuppositions behind copyright}

From the features I have described of copyright and patent, and the details that I have provided about the methods and rationale behind their policing regimes, one can fish out assumptions about the subject of intellectual property and the ontological assumptions built into the domain in general.

1. That thinking is a kind of work which expends energy. That this energy is expended from one primary source: the one thinking.

2. That there is a mimetic and hermetic relationship between a thought and its manifestation in an original such that we read cause off the product back to the thinker. (Just as there is a mimetic and hermetic relationship between the ownership of a body, the actions of that body, and the connection of ownership made between a man and the land he farms.)

3. That no one would work as an artist without compensation, i.e. the need dictates the form of life chosen. (Just as there would be no effort toward civil society, cultivation, preservation, etc, without security and compensation.)

4. That writing original literature or painting original canvasses are kinds of honest labor, deserving of legal and moral support. That watching and copying are dishonest labors, deserving of legal sanctions and moral disapproval. ${ }^{102}$

102

One only has to think back a very short while in the history of art and music production to find examples of copying being neither immoral nor criminal, but a form of pedagogy. Students learn a trade through learning to exactly reproduce their masters' styles. Copying was a form of honor and hommage. If an artist ever distinguished himself from his master, this meant that he would pursue a certain kind of career, but if he never did break with his master's style, he would still spend a life as an artist. At one time, there were hundreds of students living in Antwerp working under Reubens, learning his techniques so carefully that: 1) they often finished his paintings and 2) many paintings attributed to Reubens were probably painted by these apprentices. The culture of "original" works of art, or independently researched moments of enlightenment, defining the entirety of the subject position of "artist" is a relatively recent phenomenon. It divorces the work of academics and artists from the work of tradespeople, midwives, housewives and "mere laborers", contributing to the idea that academics and artists are an 
5. That thoughts are individuated from each other, and are produced in the minds of individuals. That a thought has an origin and a genesis, and that can be traced to a definite individual.

6. That people's thoughts/minds are their own, their natural property.

7. That thinking creatively takes effort; that not everyone can do it or does do it automatically. Art is not accidental.

8. That unauthorized use does detract from personal and overall welfare.

9. That other form/expression systems of creativity, knowledge, and information are either non-existent, not as valuable as some, not as sophisticated or do not mean as much to others as "our ideas" mean to us.

10. That knowledge comes before the signs of it, and somehow is independent of a set of signs indicating it.

11. That the best and most valuable kind of intellectual effort are ones directed toward usage and products, i.e. practical wisdom is better than contemplation, abstract thought, or thought for its own sake. Practical knowledge maximizes utility; practical knowers are virtuous because they maximize utility.

12. That thought and its expressions are a limited resource, that thinkers are in competition for scarce goods.

13. That a thought does not belong to an individual until he or she shows proof of it; and that proof of it is certain and necessary, not accidental and culturally constructed.

14. That, in principle, everyone has the capacity to work the mind. If someone does not make something of this (file a patent, paint a picture), then they are lazy or worse, evil.

15. That only expressions of knowledge can be patented.

16. That industriousness (in patent application, in writing) is a good thing; that accumulation or large output is accurate and good indicator of the qualities of the one "working" the ideas.

17. That producing a volume is better than producing a little bit, because value is created in directed proportion to the amount produced.

18. That the owner of intellectual property is more like a thing (individuated) than a relation.

19. That the intellectual property itself is also more like a thing than a relation, with the exception of a presumed "natural relation" between the two.

20. That the administered referencing of patent against registered patents on file in the patent office constitutes an exhaustive system of cross-referencing which is adequate to the task of deciding "non-obviousness and novelty" about a claim to this.

21. That percentages of usage adequately and fairly reflect the value of the copyrighted

ontologically distinct kind of being: geniuses and independent from their mentors, their materials and their communities. Surely it is this factor which is as responsible for the tangible "class gap" which exists between professors and writers, and the other professions, and not, centrally, an economic factor? Is it not plausibly also a factor in the authority attributed to the male, academically-trained gynecologist over that of the female, hands-on training of midwives which I mapped as a factor in the shifts of natality? 
material itself, and hence that redistribution of incomes from copyright fees should reflect use-value alone.

22. That wholes can be distinguished from parts, that wholes are primary, and that it is wholes which are the units which can and should attract property rights.

23. That one unique thing is uniquely produced by a unique individual at any given time. ${ }^{103}$

24. That policing rip-off copies is in the public interests, even if copying drives prices down, because in the long run, innovation will decline. ${ }^{104}$

Clearly, each one of these alone could generate enough debate to produce a free-standing thesis. Each one of these assumptions could be countered by a different theory: of the individual, of human nature, of mind, of causation, of value, of the ontological and logical relations between parts and wholes. For our purpose, we can make the case that, what we have in these is a rather clunky extension of the property model of the farmer-owner and his land to creative work and ideas. In this extension, an ideal, rank-setting personae is sketched, and a set of ontological commitments entrenched or reconfirmed. Neither of these precede the field of power which makes them possible. Neither of them exist prior to the specific domain of property on which they appear and produce effects. None of them are eternal although they may be culturally stable. This

103

Five people have claimed to be the "inventor" of the icon, happy face. (Globe and Mail, Saturday, March 27th, 1999:C-10).

104

Innovation may or may not decline. Sales certainly do, and with every single successful product, this drives profits way down. (See the figures in the sad case of the "Bubbly Chubbies"" infringement on "Teletubbies": Globe and Mail, March 21, 2000:C-1). Also, when one takes account of the hundreds and hundreds of cultural products which are "inspired by" in an unabashed way, previously published material, it is hard to make the simple case that copying decreases innovation. Consider: sampling, found sound and found poetry, modernized versions or spin-offs of old plays like Tom Stoppard's "Rosencrantz and Guildenstern are Dead", rock operas, Max Rigah's "8 Variations for Orchestra on a Theme by Mozart", and television spin-offs. (See "Copyrights of Wrongs?" Globe and Mail, Wednesday, March 24, 1999:C-1). 
will be an indication of the fluidity of the power relations which articulate and make use of these personae and presuppositions. Both have critical, but ambivalent political implications which are tied to the kind of subjects which are presupposed or extended as these assumptions are extended. I will briefly outline two of these, and discuss the roles that the Author/Genius function is playing.

\section{The Expression of the Idea vs. The Idea itself:}

It is traditionally held that only the physical manifestation of the ideas ${ }^{105}$, the works themselves, were copyrightable. Copyright law is in this sense an extension of property law which is grounded in "the physical plane", and more specifically, in the conceptual model of divisible things rather than fluid relations. However, recent examples of things which have attracted copyright and patent protection fall much less clearly and easily into the "physical end result" category. This suggests either: that the conception that an idea is different and separable from its expression is wrong; or that the conception is adequate to certain kinds of relations between ideas and expressions but not all. How we answer this question is very important. Partly, it defines the subject positions in the domain of intellectual property. For example, are creators and users of electronic media mutually supportive, or criminal? Are users exercising their right to information and freedom of expression, or are they trespassing on the rights of exclusion and the reimbursement due the ones who pioneered their way into cyberspace? Is just using the technology already a form of infraction since that form is the expression of 
another idea, the idea of software design? The means/ends distinction that the idea/expression distinction relies upon, is not so clear in cyberspace. Jeff Bezos of Amazon.com has been awarded a patent and a trademark for his special invention: the "One-Click feature", "a method and system for placing a purchase order via a communications network." ${ }^{100}$ Having a patent is not a small incidental: patent or copyright protection translates into a twenty-year government-sanctioned monopoly, which can translate to millions of dollars in profits or losses. But, James Gleick rightly asks: What exactly is this a patent for? It isn't the idea of clicking a mouse once for an order, but it isn't the "deeper" software code developed to make that happen on the desktop either, since software codes are subject to copyright yet the particular code which writes the one-click is, according to any software writer, "transparent" and "flexible"; that is, obvious. A similar claim by Compton was initially awarded a patent, which was revoked. The patent was for "what were essentially public domain routines". ${ }^{107}$ Gleick suggests that Bezos was awarded a patent on a perfectly commonplace business method, in effect, an "incorporeal bit", ${ }^{10 x}$ a gesture the hand makes which models, on the computer, a gesture everyone makes anytime they want to say "yes" to a purchase or hail a taxi. It is

Gleick (2000:44).

107

Clark (1995:38).

108

Gleick (2000:47). 
an expression, central to each and every economic transaction, transcribed in software form.

Maybe the trajectories of culture, economics and technology have reached a point where a distinction between idea and machine can no longer be sustained; where no bulwark of logic, but only the mist of undecidability, separates $E=m c 2$ from the light bulb. ${ }^{109}$

Some recent decisions on copyright infringement involving electronic media suggest that blurring the idea/expression distinction will favor the interests of producers over users, putting many more people in positions of potential criminals. "The U.S. Green Paper interprets the 'browsing' of electronic documents to be an act of copyright infringement, similar to the findings of the I.H.A.C. Copyright Sub-Committee's report." Additionally, transmission of a document itself might "define all network communication as copying and thus subject to copyright law."110 It is important to ask about the two kinds of positions that this kind of breakdown produces and who stands to gain or lose by it. Evidently, the producers of the software are going to be in a much better position in these cases, since they can be identified clearly and have a particular position well removed from the arena of use. The "potential users" lose less and less of a space to remain "potential; to make educated, consensual choices about use from: we become "users" simply by engaging with the medium of cyberspace. Not engaging is less and less of a

(ibid:48). 
daily option.

This suggests to me that it might be unadvisable to recirculate a conceptual correlation between the idea/expression and inventor/owner/user, since that particular correlation evokes subjects standing in a relation of mutual dependence with (roughly) equal chance of gain or loss: That does not characterize the subject positions which these recent patent awards create. On the other hand, if the subjectivities of this conceptual distinction, however inaccurate, play a role in preserving a space for a pre-cyber notion of a would-be user, i.e. a space of non-infraction, then these subjectivities are not necessarily to simply be discarded. It has been said that the breaking down of the real or conceptual division between producer and user, which is an upshot of cyberspace, means that "potentially, every single customer has the ability to become a manufacturer"'I. It isn't clear to me whether we should be skeptical or welcome this particular shift for its democratic promises. It is clear, however, that if this shift continues, "informed consent", "market behavior", "initiative", "communicative rationality", "liability", and "freedom of information", to name just a few concepts will have to be entirely rethought.

\section{E. What Can and Cannot be Privately Owned.}

Traditionally, certain kinds of things in the world have been considered necessary in respect to fundamental human rights or basic needs: the right to education, the need for basic information and tools, the right to privacy, the right to bodily integrity and control, 
the need for food, medicine and water. This (incomplete) list indicates universally desirable primary social goods or natural resources: "those things belonging to all, the air, running water, the sea, and consequently, the seashore."112 These have been legally distinguished from other kinds of things (luxury items, exotic varieties, gizmos) which could be, and were permissible to be privatized. There has been, until fairly recently, a combination of legal and moral limits on what kinds of things could be patented, copyrighted, bought and sold. Yet, adherence to these necessity/luxury or natural/artificial distinctions has been slipping steadily, which suggests either that these are false distinctions or that they are true distinctions which simply aren't being heeded. In either case, uncritical faith that the system works this way is outdated and dangerous. Patents have been awarded for: bacterium (the famous Chakrabarty case where genes were shuffled between three species of naturally occurring Pseudomonas sp.); ${ }^{113}$ E.S.T.'s or "Expressed Sequence Tags", which are fragments of a gene which can be used to as a marker to detect the presence of that full gene' ${ }^{1+}$; all major food crops (rice, oats, wheat and corn varieties); all major drug and medicines; water extraction and purification techniques (which, in the case of groundwater pollution, shifts this instantly from a

The Institutes of Justinian, 5th edition, Trans. J. B. Moyle. Oxford, Clarendon, 1913.

113

Vandana Shiva, "Monocultures of the Mind." Monocultures of the Mind: Perspectives on Biodiversity and Biotechnology. London: Zed Books, 1993.

114

McDonald (1999:2-3). 
luxury to a necessity); and, as mentioned above, a range of very basic business and bodily "procedures". This list should convince us that whether or not something is patented has nothing to do with whether it is morally restricted, and everything to do with whether it is technically possible to make a bureaucratic case for it being an innovation, and/or highly profitable to do so.

Access into the system of private rights itself, and recognition of rights by that same system will be much more a matter of present means (cash and equipment) to file for ownership or to fight infringement than a steady flow of basement inventors with their nifty ideas put to work as useful items into the patent office. That is, the allocation of property in ideas is a function of whether or not one has "at his disposal signs, marks, traces, letters" "us by which one is signaled as an owner and can signal back (prove) ownership.

Everything can be privatized or administered as if private property, which amounts to the very same thing. It is not only questions of distributive justice which arise here, but an altogether stranger complex of difficulties. If patents are being issued for parts rather than wholes, and if these parts are the basic building blocks of larger wholes which each and every one of us uses, needs for life, or even is -- water, air, genetic codes, protein - then again, what kinds of subject relationships do these shifts in ontological frameworks offer?

As was the case with the idea/expression collapse, the collapse of the 
artificial/natural distinction and the necessary/luxury distinction could radically transform the entire nexus of life as we know it, into a zone of property relations. That would mean that, regarding every bit of the world, one would only ever be an owner or a trespasser. Since one is not born owning things (except in the rare cases where the inheritance of intellectual property -- a proprietor's death -- coincides exactly with the birth of a successor), or owning all the necessities of life and its natural parts, then everyone will be born into a state of trespass or criminal infringement. Your parents would have to buy, in advance of your arrival, rights packages, which would delimit your user (riparian) rights to goods and services. Or worse, if your DNA was all owned by a corporation, you would be born with parts of you already owned; not at liberty to give blood or have children. This dystopian vision lines up with my earlier worries about the collapse of browser space for would-be users. If, in fact, the patenting of parts of all the physical and biological building blocks expands and joins the privatization of space (tangible property), it is hard to see how this will not expand (rather than narrow) the gap between the owners and non-owners. I have two observations to make about the role that the "author" and "owner" function might play in this extension. On the one hand, just as in the case of the quaint image of the family farmer which prevents us from realizing the trends in agribusiness are far from that pastoral wholesome truth, in the case of intellectual property, the equally quaint and pervasive image of the toiling inventor or the gifted, lone artist which lurk behind popular conceptions of intellectual property domains prevent us from realizing the extensive inroads that agribusiness and genomics are making onto that very public domain that has long been considered non-privatizable. 
On the other hand, there is a sense in which continuing to put into play, however anachronistic and inaccurate, a central image of humans as wholes - the makers, the workers, and recipients of property - might keep in play significant moral and political values which are tied to this kind of a subject: dignity, humaneness, fairness, human rights. Reconceiving a sovereign subject for intellectual property away from the worker-function, (hands or heads) may or may not lead us any closer to a more standardly conceived fair and just system of property. Michael Hardt claims that now we don't even pass through relations of labor, vocation, identity and reward, but are inscribed directly by institutions according to our infinitely expendable usefulness to direct production. He writes, "labor is less and less relevant to the social field". ${ }^{16}$ He suggests that if and when the worker is nothing, the subject is nothing, i.e. that this sovereign subject is a site of resistance not coercion and oppression.

This is not unlike the suggestion that Derrida makes regarding nuclear war. He says that the actual facts of the matter of nuclear war suggest that there is nothing whatsoever about time or space which will garner for living beings a secure reaction space: nobody can go fast or far enough to get away from a nuclear explosion. But, he says, pretending (in the sense of continuing to employ these terms in the debate) that time and space are, in fact, relevant actually manages to contain, to slow down and to organize, an important (and not entirely ineffectual) "side-space": the space of diplomatic Philosophy and Culture. Eds. E. Kauffman and K.J. Heller. Minneapolis: University of Minnesota Press, 1998:3233. 
negotiations. ${ }^{177}$ This strategy depends upon the continued investment in a traditional subjectivity, and a correlate ontology of that subject.

It isn't certain that the dystopian vision will come to pass. Another possible outcome of this reductio ad absurdum is the implosion of the private property scaffolding altogether, and a massive expansion of the scope of public resources, possibly even a reversion to riparian rights. Riparian rights are public use and access rights such as we saw in England and Europe up until the early nineteenth century. "1x If these rights were administered according to a fair system of allocation and fee, and if the inefficiencies and tragedies of the commons which caused the previous round of common property to be usurped by the private property scheme could be minimized, then this system of property could make an end-run around the gap-widening privatization system and actually set in place a fair, just and reasonable one. Somewhere between these two stories is the possibility that more things will be privatized, more people will be found in contravention, more policing will be required, of things increasingly difficult and absurd to police, more people will find ways around these limitations, many people will be better off, with expanded freedoms, while others will be made worse off, with contracted freedoms.

Second Function of the Subject: Moral concerns and their sovereign subjects.

Jacques Derrida, "No Apocalypse, Not Now (full speed ahead, seven missiles, seven missives)." Trans. Catherine Porter and Philip Lewis. diacritics 14:2, (1984):27. 
In this section, I want to focus on several features of copyright which reveal a different feature of the subject of intellectual property. Again, I will consider whether the roles that this subject plays are positive or negative, or oddly, mixed.

Like patent, copyright must demonstrate certain conditions in order for it to be protected under legal statute:

It must be original and it must be fixed on a medium....For a work to be considered original, it must be the result of its creator's personal efforts. Copyright protection covers the specific manner in which an idea is expressed; the idea itself is not protected."19

"Original", however, is not simply "novel". With this distinction, copyright turns out to be more stringent than patent and to introduce a substantively different element into the domain than those which are expressed in the first sovereign subject, the owner-function. Original work must satisfy the demand that the form of expression be original and not copied from something else. plus, it must be original in the sense of originating from the author and not someone else. Furthermore it must,

involve sufficient level of creative, intellectual, artistic, discretionary, imaginative effort and judgement, not merely 'sweat of the brow' or mechanical in nature. ${ }^{120}$

Who the rightful owner of copyright is, then, is not just quantitative matter. There is some unique qualitative component to the kind of person who can and should be recognized as

Wilson and Burpee (1990):2). 
a rightful owner of ideas: an author, a creative genius.

Among the justifications for intellectual property are some which pertain to what is owed to this particular subject insofar as being that kind of a person, there is a special category of dessert which applies to them, or harm which could be accrued them.

Although these harms are expressed less often and less elaborately than the economic-utility arguments, they nonetheless are present to considerations of intellectual property, and thus form another normative background for the domain. Like the worker of tangible property, part of this normative background is the function of carrying into the domain, and extending, the lines of authority of certain virtues and values.

There are a number of specific claims regarding the necessity of intellectual property rights and policing thereof which focus on, and attempt to shore up, the potential loss of, or threat to, "moral" or "personal" goods which would occur in an unregulated (non-privatized), open system. These reveal certain additional assumptions about creative work and the person behind the work which frame quite clearly a second sovereign subject. All of the presuppositions about the owner-function listed on pages $260-2$ also apply here, raise the same kinds of issues, and would lead to the same aporiae that we saw vis-à-vis the utility of privatized "intellectual work". However, the stipulations associated with protecting authors and inventors from moral harm can be examined as another normative framework, with another set of aporiae.

One assortment of those has to do with harm to reputation. There is the stipulation that a copyright holder has a right to decide when a work is ready to be screened or 
circulated, and a right to withdraw the work at any time from the public domain ${ }^{121}$. There is the stipulation that an author (or her estate) must be consulted for approval and permission whenever another work is produced which draws directly or indirectly from the original material. An individual or his heirs has the right to veto any derivations, independent from monetary gains arguments. An artist must give permission for his or her work to be integrated into any other commercial ventures: advertising, design, layout. Lastly, there are particular conventions within copyright and patent domains which require the user to acknowledge the source, even when they are fully legally and economically entitled to use that source, having purchased copyright rental, bought a public performance license, paid user fees, or if the work subsists in public domain under fair-dealings guidelines. These conventions, which everyone is quite familiar with, include citational requirements, the addition of the universal copyright symbol, statutory acknowledgments and gratitudes posted on video and film. In some cases, it may involve demonstrating that one has requested permission for reproduction (even if one hasn't received it). On the other side, the author's signature or in its lieu, the permission of the publisher, is taken to indicate purview and approval. The name of the author itself is require adherence to conventions. However, this will depend upon whether or not there is a third party (publisher, granting agency) between the creator and the user. The third party may claim other rights on behalf of "the community of all artists" which could prevent one individual artists from alienating these rights. 
subject to protection, as we have seen in recent internet domain name court cases. ${ }^{122}$ All these stipulations and conventions have little to do with monetary interests. They speak to a unique set of assumptions about the character of the author, the nature of a created work, and especially, about the relationships between these. They suggest that intellectual properties are distinct from other properties in substantively relevant ways, and thus they suggest, normatively, that intellectual property must be handled (legally, morally, culturally) in distinct ways. I will examine two of these assumptions, and flesh out the subject of these assumptions.

\section{A. The Integrity of Artistic Work}

Foucault's (and others') critiques of "the author" are not new. The assumptions about integrity and intentionality which I will describe have been examined very closely, especially in terms of literary criticism. However, they don't seem to be making any headway against an equal and opposite tide (scientistic, economic) which reconfirms the author (or the creator) vis-à-vis patent and copyright protection. Let's look at these assumptions again against a background other than aesthetics.

The chief assumption is that "the work" has an integrity and a meaning; that these were put there by the author or inventor, or produced through the relationship between being a writer and writing something or being a painter and painting something; thus that the integrity of both the creator and the work depends upon the creator having 
consultative and controlling positions vis-a-vis her products. This control includes the assumption that there is an innate, accurate sense of when nothing more is needed for the work to be "finished" or "ready to go", and an innate sense of the integrity of the work as a whole, such that he or she knows (or his family executors, who inherited this innate sense), and must be consulted regarding the contexts that the work appears in, the variations or renderings of the work. The famous Nabokov spin-off "Lo's Diary"123 is a case in point, as is the refusal of Beckett's executors to allow an all-female staging of "Waiting for Godot". In these court cases, a frequently displayed premise is that it is the author and the author alone who has a particular sense of the work: its real meaning, its true intended effects, its acceptable or unacceptable applications or contexts, its relation to the person of the author herself as an expression of that person, its private logic in relation to other writings. While a biographer can try to make a case about this, it is the author's final say about the accuracy or inaccuracy of the interpretation which will stand. These stipulations about meaning also suggest that the author herself is a kind of finite unity (a closed set of clear wishes, a given range of style) and that the work is a kind of finite unity, a receptacle which has received, once and for all, the stamp of these intents. This is to say that the author or the genius is a kind of styled thing, as is her creations. These ideas are a ruse for the money and rights at stake.

The related moral dimension has to do the value accorded to this relationship, and with creating the space for it to be recognized again and again as special. But, there is

Pia Pera. Lo's Diary. Farrar, Straus and Giroux, 1995. 
also something more. There is a kind of reverence for the author or the creator of gizmos which entails putting into place conventions for creating and protecting the status, the entire life and character, the reputation of that person, as a special, unique, heroic, even holy kind of subject. Foucault wonders, "at what point we began to recount the lives of authors rather than heroes...?"12s Looking at any number of examples causes us to suspect that there is much more at stake here than simply "protecting" an established relationship between a person and her property. For instance, consider the horrified warning that soand-so wouldn't appreciate finding her work in a pornographic magazine, or being used to sell some sort of product. This suggests that someone knows (from the work itself? from a close relationship with the artists? from a cultural context?) something and is in the position to reveal its truth. Consider the preponderance of biographical information on writers, both as independent books (suggesting lives of still others as lives worth looking into) and as part of the common structure of novels, essays, books of poetry, giving us the fuller story first through which we are to read, understand, make chronological, geographically locate, authenticate, the writing through the writer. This trend is replicated in literary theory, and in many other domains of knowing (the "intellectual" as the "author"). As a writer, there is very strong pressure to reveal to the public details about one's private life. Refusing to do so is met with resistance and judgment. ${ }^{125}$ This is odd

Foucault (1984c:101).

125

If I cite the source of that comment (a friend, a well-known writer), then I myself use the "moral force" of insider information rhetorically. 
considering that if and when that information is revealed, it will be applied to arguments about protecting the private interests and the integrity of that same reticent author. This is not just about information; it has to do with the power that knowledge passing through a persona of an author gathers in discourse, even, in the discourse of property. It also suggests that the author-function, in the realm of property, is a node around which the idea of the public/private is continuously deposited and maintained. In the realm of intellectual property, especially the privatization of genetic information, the ruse of authorship or inventorship is especially useful.

In Foucault's "What is an Author?" he concentrates for the most part on literature. However, he explicitly declares that what he is articulating -- "the author-function" - is not confined to the writing of books, but is,

The mode of circulation, valorization, attribution and appropriation of discourses.... The manner in which they are articulated according to social relationships can be more readily understood...in the activity of the author function and in its modifications than in the themes or concepts that discourses set in motion. ${ }^{126}$

The author/genius-function establishes social relationships (and more) in the discourse of intellectual property. It does so in tandem with the owner-function in such a way as to both borrow its notion of work, and to exclude its subjects as mere laborers.

In these conventions and modes of commentary, there is the deposition of the characteristics of author and genius, and in this deposition, the insertion of values and presuppositions, cultural and ontological. Certain relations are established by this

(ibid:1 17). 
deposition, while others are annulled. There is no "author" or "her work", or "genius" and "his invention", but these are both individuated, marked, signified, endowed and, in this case, inserted into the domain of property as sovereign subject. Notice how this sovereign subject is perfectly private (distinguished from all others). As we know this distinction occurs simultaneously with the exclusion of an anti-subject (the mere copyist, the dullard masses of the uninspired, the group effort, the cheater, and even the doing-it-just-for-the-money). If the tenacity of claims to ownership in ideas rests upon the ability to make the case for sui generis, unencumbered production, or upon a mode of production which defers to a pedigree of citation and has respected a procedural sequence for making those claims, then those who are able to take up the subject position of the author or the inventor will be in a much better position than those who are further from those ideal personages.

According to Foucault, the author of any text is not well-represented by the common notion of the author. This author is a progenitor site within which ideas are gestated, from which ideas are born (or birthed ${ }^{127}$ ), in a continuous causal-physical relation. In this conception, the one whose creative work it is, is conveyed unilaterally to the world, as is the work itself. Taken together, they form a "fundamental unit". ${ }^{28}$ Foucault identifies what he takes to be the four chief modes of the author function; that is,

See Plato's Theaetetus, on the model of mental activity as birth, and the mentor as the midwife. 
the specific gestures and endorsements and the general ideas, through which the "commonsense notion" of an author has been built. Those are: work, writing, name and author.

\section{B. Work, Writing, Name, Author}

First is the notion of the work. This notion designates a problematic unity, for when someone has been designated an author, we have to decide "whether everything he wrote, said or left behind is part of his work". To leave a laundry list out of "the work of this one author" requires justification, since it counts among the many intentional, personal, stylized traces that this person leaves which could be taken as part of the code.

"I have forgotten my umbrella." These words were found, isolated in quotation marks, among Nietzsche's unpublished manuscripts....Maybe a citation. It might have been a sample picked up somewhere or overheard here or there. Perhaps it was the note for some phrase to be written here or there. There is no infallible way of knowing the occasion of this sample or what it could have been later grafted onto.... ${ }^{129}$

Foucault suggests that the difficult technical and philosophical question - what is a work?

- is answered, reversing the referent and its deposition, "is it not what an author has written?" The author, then, is not the source of genius-work, but the place where it is deposited, as a cultural value. We saw the same thing previously with respect to the value of "industriousness".

Second is the notion of writing (écriture) as deposition of meaning, a means to "transpose the empirical characteristics of the author into a transcendental anonymity". 
Where writing has a being independent of authoring, it does not divert us from inquiring about the author, but conceals the author in a more devious and significant manner, "giving primal status" to the writing and above all, to decoding it. Here, Foucault suggests that the deposition of the sovereign subjects author/genius coincide historically, with the emptying of the sacred characters of the church and the activities of textual interpretation focused there. In other words, the power relations which produce a feature of specialness, of meaning, of transcendental authority in the author and in his text have entered literature and now property, from theological discourse.

Third is the author's name, and hence signature,

"not...a proper name like the rest...not simply an element in a discourse capable of being either subject or object, of being replaced by a pronoun, and the like; it performs a certain role with regard to narrative discourse, assuring a classificatory function. ${ }^{130}$

Since there is a tradition of organizing texts (and in our case, assigning ownership to them), there need to be means of establishing relations of continuity, inheritance, similarities of style, school, content, function among the texts of a given author and across the multitude of "created works". The proper name of an author serves the role of creating a term under which unity can be organized. The force of alignment that an authored text has to other texts is not simply a legal manoeuver (like a guarantor to a contract), nor simply an expression of relation (like the signature on a private letter), but is a particular status within a tradition, a set of institutions which mark creative work as Neb.: University of Nebraska Press, 1986:1-10. 
distinct and coherent. Proper names of creative geniuses, gives creative genius a name, in other words, status. This is not just the status of the author, it pertains to the status of a discipline itself, and its rightful foundations. Contemporary science gains a great deal of general approbation from its hero figures, its historically founding figures, and its potential future geniuses. Foucault suggests that this validation applies equally to scientific theories and inventions as it does to art, which helps to explain the massive funding and the hands-off respect that science receives.

Fourth is the author itself, a "certain rational being", and an "authentic human being" who is required to display rationality and authenticity as such. She also must display a set of values and psychological attributes in the unity of meaning and intention which is "discovered" in his or her works. "Works" are characterized according to whatever needs to be manifested in a particular discourse. This is somewhat of an obvious point: whatever cannot be made to manifest that projection will not qualify as artistic works or will not be sustained as an example. Foucault's musing that this might even progress far enough -- according to social changes -- that the author-function will disappear reveal that his attention to the author-function lies in its power-relations capacities, not in its actual desirability. On the one hand, we seem to be seeing a surge in the attribution of works to individuals, a hyper-entrenchment of the author-function in the face of cyberspace; on the other hand, there is a corollate surge in the concept of, and amount of, "information", which is an entirely different conceptual apparatus than the “authoring" mode.

This suggests that what is significant about the author/genius-function is that, 
while the broader, public discourse is expanding insofar as it suggests that intellectua! property protection is necessary for the amplification of cultural products and their maximal circulation, in fact, the deposition of the author/genius subject prevents this. The "author" and "genius",

...is a certain functional principle by which, in our culture, one limits, excludes, and chooses; in short, by which one impedes...free circulation, the free manipulation, the free composition, decomposition and recomposition.... ${ }^{13 !}$

With regard to intellectual property, all evidence seems to support Foucault's suspicions. The ability to claim inventorship (first to create) is directly related to the ability to prevent the circulation of ideas and things. However, there are features of intellectual property regimes - its laws and most importantly its mechanics - which have nothing at all to do with the inventor per se. They have to do with access to tools for marking and with speed: first to file, rather than who files. While Foucault's ideas remind us again to rethink the alleged link between creative intention and outcomes as property (or proprietary) link - and this critique applies anew to inventors and their patents relations of productivity and ownership beyond this simple dyad require a different critical focus.

\section{Summary of Chapter Four}

In this chapter, I examined the characteristics of, and the functions of, the 
sovereign subjects specific to the domain of property. I began by making explicit economic/utilitarian considerations and moral arguments which are found in the central debates on property: what constitutes the optimal mix of public and private property? I claimed that the same principles can be found on opposing sides of the same argument. From this, I suggested that debates on property are animated by a conception of the ideal subject of property, and that these subjects (or personnages) lend those moral and economic arguments a normative and conceptual structure. That is, the ideal subjects "carry" virtues and value, and they also express ontological commitments in a discursive field which can divide that field into owners and non-owners, public and private interests. I identified the owner-function who animates the debate on tangible property. Next, I made explicit the range of philosophical, moral, epistemic and economic presuppositions which this ideal forwards: what kinds of subjects could own property (intellectual or otherwise), what kinds of things could count as privatized (things, ideas or their expressions), and what kinds of relations between a subject and his or her efforts were being assumed. In this, I made the case that the presuppositions behind attributing ownership and the capacity to be owned to things had political ramifications, but what those were would need further unpacking.

To this end, I explored in detail only two of these presumptions which had been extended from property in things to property in ideas. My aim was to try to discover how these assumptions functioned in the newer domains of cyberspace and genetic engineering: that is, what role the subjects of intellectual property played, what values and possibilities they were extending. I discovered that: 1) these presuppositions are 
weak and ambiguous, therefore their assumption represents an ontological bias rather than a true reflection of the nature of property in ideas, and 2) whether the application of these ontological presuppositions, the extension of these subjects to the field of intellectual property, would be threatening to human freedom or would radically expand it, or would lead us toward or away from social justice, was unclear. The sovereign subjects could effect a range of power/knowledge relations. There appear to be different possibilities that this figure gives rise to, thus different assessments of the desirability of that figure per se. In plain English, even though I have identified "the author" as playing a very important role in how property "works", I can't say with certainty what that role is, and therefore whether we ought to be promoting that subject or, as Foucault suggested, "we ought to be participating in the production of a new subjectivity".

This is to suggest that definitive evaluative principles cannot be discovered in these figures per se. While the figure of the author or the small businessman "organizes" aspects of the field of property, establishing a standard around which individuals can be discerned as normal and legitimate subjects of ownership, and providing a node from which moral and philosophical principles speak - efficiency, rationality, inspiration, integrity - these two functions alone do not get to the core of the subject function. I claimed at the beginning of this chapter that there was a third function. That function has to do not with the "content" of a subject, but with the structure of the relations that a subject forms.

In the next chapter I will return to the idea of power. I will analyze the field of power not for its content but for its formal relations. This will allow me to analyze the 
subject as a formal feature having formal effects. I will establish both a catalogue of potential formal features of domains and an evaluative framework from these possibilities by which we can then make an assessment of the value of these two subjects of property. 


\section{Chapter Five: Cartography}

\section{An Overview of Where we are So Far:}

In the last chapter, I examined two of the three functions that a subject performs in a discursive field. "Decidability" is the third function. It is a general function which a subject position per se brings to any field. "Decidability" is a function more closely related to features of a field of power than to any specific feature of a kind of subject, such as those I explored in the previous chapter. This chapter, then, will examine what I mean by this third function, and relatedly, what I take to be its evaluative capacity.

A precautionary note: This discussion will take us to a level of abstraction which may seem to have abandoned property altogether. It hasn't: we are still looking into the kinds of forces that have gone into building the domain of property so that we can arrive at a comprehensive picture of these forces, and use these to then build up some sort of an evaluative frame, or at the very least, to derive some critical principles. In the first chapter, I argued that we had to go deeper than historical analysis or normative analysis; that we must combine these as critical ontology, which would allow us to look at the conceptual presuppositions "behind" historical or normative views, and would also require us to ask after the ways in which those views are power/knowledge relations which themselves affect the discourse. The second chapter was devoted to sketching how a Foucauldian view of power can put a large variety of factors (theory, ontological presuppositions, history, persons, knowledge) into a comprehensive plane from which we can begin to understand how these factors, both at a micro and a macro level, work 
together to produce a field like "property" over time and space. In the third chapter, I tried to separate out the various kinds of forces which are implicated in the production of "the public/private distinction", a binary not only central to the domain of property, but one in which I participated as a pregnant woman and a mother. In that, I tried to consider how, exactly, my positioning contributed to the formation of the field upon which I operated, including my interpretation of my experiences. Having isolated the emergence of "authoritative figures" as a key factor in the production of public and private space, in the fourth chapter I looked for the kinds of authoritative subjects native to the discourses of property, both tangible and intangible. My aim was to show how normative and historical evaluations were ultimately anchored in the functional roles of those subjects as power/knowledge positions, rather than the principles and values that these subjects are conceived to be the recipients of. The fact that there is ambiguity as to the kinds of effects that specific subjects produce or the kinds of ethical and political principles they can lend support to led me to suspect that the content of a subject position (such as "an owner" or "a thief") contributes one kind of "force" to a field, but that simultaneously, there must be something else about the subject position which is responsible for the kinds of possibilities inherent in it. I am suggesting in this chapter that that "other force" is its formal characteristics. An analysis of formal (or spatial) characteristics, and the practices of resistance which are entwined with them, involves the following assumptions:

First, all possibilities are themselves spatial relations -- "resistance is never in a 
position of exteriority". ${ }^{132}$ Second, that resistance or change effected will always be relatively versus absolutely successful; this is true too, of the accuracy of analysis of the structures of relations. Third, given that I am within rather than outside these machinations, my understanding of these spatialized relations is situated and partial. Fourth, that what constitutes "toward freedom" or "a successful, desired, resistance" is always framed from a position which enters into the form of what a success or failure would be. Fifth, that positions are always the result of multiple intersections of relations, therefore offering to analysis, multiple axes upon which to make assessments. The task of assessment falls to what I'll refer to as "cartographic analysis". Its job is to map out formal relations and hence to suggest a map of resistance.

Resistances...are distributed in irregular fashion: the points, knots, or focuses of resistance are spread over time and space at varying densities, at times mobilizing groups or individuals in a definitive way, inflaming certain points of the body, certain moments of life, certain types of behavior. Are there no great radical ruptures? Occasionally, yes. But more often one is dealing with mobile and transitory points of resistance, producing cleavages in a society that shifts about, fracturing unities and effecting regroupings, furrowing across individuals themselves, cutting them up and remolding them, marking off irreducible regions in them, in the bodies and minds. ${ }^{133}$

\section{Cartographic analysis}

Cartographic analysis asks after the particular ways in which things, objects,

Foucault, Michel. The History of Sexuality, Volume One. Translated by Robert Hurley. New York: Vintage, (1980a):95.

133

(ibid):96 
ideas, desires, and power/knowledge relations are distributed insofar as they could be said to "have" location. These locations might be in things or centers, or in boundaries, in limits. Between a point and a limit locations are also exhibited in formations, in shapes, patterns, fields, planes and lines. This locatedness and dimensionality is not restricted to spatial extension, but pertains to that aspect of any field whereby locatedness is a kind of potentiality which is functionally effective. Cartographic function is not, strictly speaking, a principle of residence or location, since we are not only interested in maps and points, but in the kinds of transformations ("becomings", "resistances") which give rise to, and can efface these locales. Cartographic function is not a principle of geographic distribution. Cartographic function is micropolitical, involving the discernment of formal relations, between skin, thoughts, countries, claimants. These formal relations are intrinsically related to the capacity to be free or to judge.

It isn't the case that phenomena are nothing but dimensionality; that is, wholes created by and reducible to efficient causal mechanisms which render Reality as nothing more than extension. I am not saying that "truth" or "green" are not real. Nor that their realities consist entirely or even primarily in their formal features, such as the distance of green from grue or blue. My project is ontological and practical, not, ultimately metaphysical or epistemological. I am interested in how dimensionality-- as matter, as force, as a field of ideas which are shaped and which "shape"- is a constitutive aspect of the power/knowledge story. I am interested in how techniques of spatialization are exercised and how these function: what are its regularities and ranges? Although I myself am located in this investigation of effects, I am not presuming (nor even arguing against) 
whether or not human cognition holds a particular position (origin, ground, stage, end) in the overall play of spatiality.

\section{Third Function of the Subject: The Subject and Cartography}

Power cannot operate in a vacuum. It has to create (or access) a field of operation, inflect a space of actualizable possibility, a node to which relations can be anchored. The most effective way in modernity that power can be inflected are through the relations between power and knowledge' which inhere not just "anywhere", but in the actual subject.

Subjectivities are, among other things formal features of power domains. They can be understood as structural elements in the general grid of power which individuates subjects. Subjects have shape or form, and give shape or form to the relations that they are in, depending on how they are arranged. A subject effects and is effective in a field of power through this formal feature, in addition to other features of subjects: their content, their material, their tempos. These effects are in addition to a subject's substantive features. All subjects have formal efficacy in discourse, regardless of their specific type or the precise domain that they are operating in. Sometimes the formal effects are quite distinct from, even in direct opposition to, apparent or substantive ones.

Formal relations are kinds of power relations. The subject is a specific spatialization or distribution of power. Relatedly, the effects which a subject makes

Michel Foucault, "Two Lectures." Power/Knowledge. Edited by Colin Gordon. New York: Pantheon, 1980b:98. 
possible also have spatial features, features independent of the content that the events display. I call these features "the cartographic features" of power. "Cartography" is:

...the presentation of the relations between forces unique to a particular formation...the distribution of the power to affect and the power to be affected...the mixing of non-formalized pure functions and unformed pure matter. ${ }^{2}$

If the formal features of the subject position involve the power to affect and to be affected, then the key role that subjectivity plays in the overall architecture of discourse is to support the capacity for normativity, for decision, for judgment. Normativity depends upon formal features of a domain.

In the first instance, discipline proceeds from the distribution of individuals in space. ${ }^{3}$

Normativity -- the possibility of judgement (conceptually and actually) -- is ultimately a function of the formal features of power domains, formal features that subject positions offer. It is not a function of their specific contents: values, virtues, theories of ethics, customs. These too are dependent for their operation upon the structural possibilities of judgment itself.

What I mean by the "formal features of power" are the kinds of arrangement or distributions that relations of power are organized into. We tend to discuss

Deleuze (1988a):72-73.

Michel Foucault. Discipline and Punish: The Birth of the Prison. Trans. Alan Sheridan. New York: Vintage, 1979:141. 
"power/relations" by and large in terms of their content and the specific field that these pertain to, for example, "books" and "students" and "education". What I want to suggest is that how things and persons and words are actually formally arrayed or organized on a particular field, have something to do with the kinds of forces that these power/relations are or can enter into. Rawls writes that, "liberty is a certain pattern of social forms."4 Positive and negative liberties, including the freedom to evaluate and the freedom from judgment, are tied to the structural possibilities which subject positions, in a matrix of wider sociopolitical relations, offer. Thus, through the structures of judgment, the subject has active relations to normativity which are different from the two roles we saw in Chapter Four: setting domain-specific exemplary figures and importing specific values "within" that ideal personae.

Ethical judgment is a mode of knowledge whose operation requires the structure of intersubjectivity. Intersubjectivity presupposes a distribution of selves in space or in time. Belief would be another mode premised upon the distribution of selves and objects of belief. Judgment is a particular kind of power/knowledge relation: a normative one. Knowledge and normativity are linked in the very possibilities of judgement, not simply what judgements are about. That is to say that the notion of judgment about selves is dependent upon a structure, possibly conceptual and possibly actual, a structure

John Rawls. A Theory of Justice. Cambridge: Harvard University Press, 1971. 
conducive to the activities of evaluation. ${ }^{5}$

Normative relations are expressed in and through subjects in the interpersonal activities of judging and being judged. Both are activities. They have aims behind them and effects which follow from them, though they can be differentiated according to degrees of activity. Being judged is an active component of normativity, since ethical judgment, a power/knowledge relation, always occurs between two subjects. This suggests that the uptake of subjectivities is not unilaterally imposed, but is established from a particular place in relation with other relations. Judgment itself is not unilateral, but is co-capacitated by the one judging and the one being judged, though in different ways and measures according to the formal possibilities available. It is only by refraining from occupying any particular subject position, from refusing the authority that it offers, that one refrains from participating in the structures of judgment. Since, insofar as we identify as individuated persons, we are never free of power relations, the goal is not to repudiate judgment altogether, but to discover the formal features of the particular subject positions we occupy, and to understand what modes of judgment and being judged we are therefore implicated in and extending.

In "The Order of Discourse"," his inaugural lecture at the Collège de France, Foucault set out his plan of work and offers a general hypothesis about discourse. The

Linda Alcoff, "Davidson on Truth." Real Knowing: New Versions of the Coherence Theory. Ithaca: Cornell University Press, 1996.

6

Michel Foucault, "The Discourse on Language", appendix to The Archealogy of Knowledge. Trans. A.M. Sheridan Smith. New York: Pantheon, 1972:215-237. 
two are connected in the sense that Foucault wishes to work as a political philosopher and hence must be able to introduce or at the very least, work with, critical principles which could guide his own intellectual labors. These critical principles derive from the study of ontology,

The point in doing ontology is not to arrive at an understanding of the way the world is structured, but to be able to take up a certain viewpoint toward the world in order to engage in certain ways of living.'

These two goals are not mutually exclusive. My goal in this chapter is to first of all try to "arrive at an understanding of the way the world is structured" by extending Foucault's account of power to include the way that power is structured. In Foucault, we can uncover two distinct regimes of power, distinct by virtue of their formal or cartographic features. Each has a different structural mode of power and thus a different form of subject relations. The first regime is that of Sovereign or Juridical power. The second is the regime of Disciplinary power. There are also variations on these two including a Primitive Territorial Segment (amorphous) and a post-disciplinary form (circular self-relational). The first of these is described (though not as a "power regime") by Deleuze and Guattari. The latter is discussed by Foucault but can be expanded upon as a combination of features available in the three other regimes. For each regime of power there is a particular subject function which performs judgment and upon whom judgment can be visited. The structure of the subject is tied to the structural mode of power in which it is operating. Thus, one way to investigate the formal features of the subject is to

Todd May, "Gilles Deleuze and the Politics of Time." Man and World 29:3 (July 1996):294. 
examine the formal features of the power regimes one is operating within.

Second, I will assess whether it is the case that what follows from this account of structure is, if not a set of critical principles, at least a certain critical viewpoint. Foucault seemed to believe that these were available in the exercise of mapping power relations. I would like to explore how two very important sociopolitical principles -- freedom and oppression -- are functions of how a subject operates as a formal principle. Freedom and oppression are related to what strategies are or are not available to different kinds of subjects in those formally distinct regimes of power. I will begin, then, by identifying what critical viewpoint Foucault thinks is available, then I will connect this to a formal analysis of power.

\section{Containment and Uncontainment}

Among such potential critical principles we find a formal one: at the heart of Foucault's evaluative framework lies resistance to constraint. Constraint is an ontological descriptor. Foucault does not use this terminology; however, where his writing is evaluative, he differentiates what I call "containment" from "uncontainment". These are ontological, rather than aesthetic or political principles, though there are relations between an ontology and aesthetic or political possibilities which an ontology gives rise to.

"Containment" is the pulling in of forces, the decrease in connectivity, serial alignment, or the tendency toward interiority. Uncontainment is the unleashing, 
multiplication of points of contact, or tendency toward exteriority". Foucault equates containment with fascism?, regardless of whether we are discussing a form of government, ${ }^{10}$ a bodily attitude,, 11 a form of discipline, or habits of thinking. ${ }^{.2}$ If containment carries a negative value then its opposite carries a positive one. Foucault's positive program almost always consists in encouraging us to notice and then to loosen (as much as is possible) limit-setting constraints. His notions of resistance and transgression involve estimating and negotiating limits ${ }^{13}$ rather than setting out a pre-ordained substantive position or aim. Certainly, a traditional sense of "emancipation" is not available as a political aim within a Foucauldian framework. This is because of the model of power that he offers. The traditional sense of emancipation, based on a model of power as something one has or does not have, is the idea that one can achieve a freedom 8 Thought." (1988a:94-123).

On the difference between the two in Foucault's thought, see Deleuze, "Foldings, or the Inside of 9

Michel Foucault. preface to Gilles Deleuze and Felix Guattari. Anti-Oedipus. Trans. Robert Hurley, Mark Seem and Helen R. Lane. Minneapolis: University of Minnesota Press, 1983:xiii.

10

Michel Foucault, “On Popular Justice: A Discussion with Maoists." (1980b:1-36).

11

Michel Foucault, "The Politics of Health in the Eighteenth Century." (1980b:166-182).

12

Foucault, Michel. Maurice Blanchot: The Thought from Outside. New York: Zone Books, 1987.

13

Michel Foucault, "Preface to Transgression." Language, Counter-memory, Practice. Trans. D. Bouchard and Sherry Simon. Ed. Donald Bouchard. Ithaca: Cornell University Press, 1977:29-52. 
from power, or release from a suffocating memory or even from being a certain kind of a person. There is an image of emancipation available in that traditional view: that one is at a point in chains, a slave, and then, one is released from this, is a free person.

Within a Foucauldian framework, any given individual is, at every point, engaged in innumerable kinds of relations (many unknown or indefinite, many with unpredictable outcomes), and one is never entirely "free from" these, or from "who one is".

Emancipation as it is known in the liberal framework is an inappropriate goal. The emphasis is on the process of struggling to understand the forces that one is affected or contained by, and to reorganize the relations that one is actually in, in order to gain some space for creativity and affirmation (rather than habit and reaction). Where something like "freedom" is an aim, it is not seen as an end which regains or maintains some natural or species-specific base line of freedom or autonomy. The unencumbered self is neither our natural state nor our telos. Rather, Foucault's concept of emancipation involves recognizing and reorganizing "encumberances" from our own specific and potentiallyshifting positionality. ${ }^{14}$ There is something of self-mastery in this deliberateness. Commenting on Deleuze and Guattari's vision of resistance in Anti-Oedipus, Foucault finds a spirit of agreement, and adopts their language to reiterate his own anti-fascistic vision:

David Couzens Hoy, in his introduction to Foucault: A Critical Reader. Oxford: Basil Blackwell, 1986 locates Foucault's "freedom" in a heuristic device built into genealogy whereby one, in studying and recognizing the network of forces which have driven, and continue to drive, any discursive phenomenon, also simultaneously recognize the fact that (if not the degree to which) one is not fully encumbered by these forces, since one is seeing and understanding them. (13) Foucault's theory of freedom is predicated on active engagment and recognition of positionality, rather than prior to, or independent of it. 
...Develop action, thought, and desires by proliferation, juxtaposition, and disjunction, and not by subdivision and pyramidal hierarchization...Prefer what is positive and multiple, difference over uniformity, flows over unities.... 15

\section{Discourse, Containment and Freedom}

Foucault sees discursive production itself as a tending toward containment. He describes discourses as "disquieting social products"; they are not necessary, natural or benign. Their production and propagation help to effect the overall functional role of containment, they introduce regularity, order, identity into material and social reality where formerly there is dispersion, irregularity, anonymity. They deploy action upon action. This is the general function of discourse per se, over and above the specific roles played by specific discourses to delimit particular domains. Foucault's thesis is that discourses in general are the result of, and are subject to, a set of procedures and limitations -- external, internal, social and philosophical -- whose common end is to "...gain mastery over any chance event, to evade...ponderous, formidable materiality."।s

As we know from the previous chapters, specific discursive fields -- health, family, property -- are the local effects of the principle of differentiation at work: binaries are established, realities are drawn, quartered, tagged, put into speech, positioned, referenced, contextualized, written down or attributed to one among the many. In this way chance ("the most dangerous and rich part") is "displaced" and "exorcized".

Foucault (1983b:xiii).

Foucault (1972b:216). 
Discourse is conservative-tending, via the constant shuffling to the outside of multiplicity, the policing and shunning of the incoherent and the putting into commonsense and plain speech whatever threatens to irrupt. Discursive production is a process of rarefication. Discourse is not a neutral, or benign activity because its very fact conditions the realities of those internal to and external to it.

The production of personages such as those we examined in the previous chapter is one of the chief means for managing and containing this ponderous, formidable materiality. The characterization of specific subjectivities (the farmer, the tally-stick boy, the mother), the affirmation of these identities and the uptake of certain values expressed by those identities, helps enable the structural work of containment. As we saw in the last chapter, internal to discourse, subject positions levy acceptable and unacceptable ranges for personae. These subjects not only smuggle values into their roles and onto a field of relations, but their very position suggests the possibility of "an ideal", "a truth". This idea of normal which a subject animates, "reinforces the limitations and exclusions...that bears...on the specific reality of discourse in general."17

In light of this, Foucault remarks: "in those figures which seem to play a positive role, e.g., those of the author...we must rather recognize the negative play of slashing [une découpe]...."1s

Michel Foucault, "The Order of Discourse." Trans. Cyril Welch. 1999:22.

(ibid:22). 
Why must we recognize this slashing? What is at stake in slashing or resisting slashing? Foucault's suggestion is that it has something to do with a very abstract or macro form of violence:

We must conceive of discourse as a violence which we do to things, or in any case as a practice which we impose on them; and it is in this practice that the events of discourse find the principle of their regularity. ${ }^{19}$

Découpage is ontological. It has to do with the expansion, rather than the contraction of the space individuals negotiate, as a discursive space. It isn't about absolute delimitation of freedom, and perfect lack of constraint. As mentioned above, these are not realizable states. It has to do with whether the space individuals negotiate is already fairly rigidly organized, or whether it is in some way, relatively free of inscription. The more that a space is already inscribed, the less a given individual can negotiate or experience the relations of that space actively, from their own specific positionality. For example, when dialogue about mental illness began to enter the space of criminal investigation, what appeared to be the expansion of possibilities and freedoms for any particular individual who found him or herself party to a trial- i.e. that they could be found "insane" or "sane", and/or "guilty" or "not guilty" where previously he could only be found "guilty" or "not-guilty"- in fact doubled the discursive density of that space. This kind of macro shift changed the kind of thing a trial is, for everyone involved in trials, from that conjunction onward. Foucault has argued, I think successfully, that in many ways, the mental illness domain permits an amplification of invasiveness and control of the

Foucault (1972b:229). 
"subject of investigation", in other words, amplifies the possibility of his being

subjugated. This applies too, to the range of expertise expected of, or accorded, the judge, the jury, the lawyer, the prison attendants and the parole officer; it extends the range of judgment that they "offer", not only on, say, a particular pedophile, but on sexuality and mental health and legality in general. Thus, in the invocation of an adjacent discursive formation or personae there is a very abstract and macro, but essential kind of containment realized.

Even if there is not an identifiable agent who is "behind" the découpage engineering containment according to his or her own fascistic expediencies, and even if there is not (yet) a particular recipient, or a violence locatable in a particular incident of harm like a rape, we can still speak about a kind of violence at the level of discursive formation in the way these shift and join. It is not that each time a parent delimits the specific freedom of a child that child is automatically the victim of violence. I sometimes ask my daughter not to wear so much makeup, or to do the laundry when she would clearly rather not. But these kinds of demands have two very different possible genealogies. Insofar as these rules are really disguised judgments (that child is too lazy for a child, that 12-year-old girl looks too slutty for a 12 year old girl) which arrive from without, via my placing her and myself in relation to an abstract ideal or an anti-ideal of childhood, of femininity, of work habits, of sexuality, of parenting, then I think that this delimitation is indeed a kind of violence ushered into a particular occasion. On the other hand, sometimes those requests don't seem to come as much from 'without', and don't seem to involve treating her, and myself in relation to her, as a set of generalized 
relations. They arise from the particularities of our specific situation: how much laundry there is, how tired I am, how much of the laundry is hers and how much mine, whether she has homework or not. In this last scenario, there is the active possibility that she can offer a counter-proposal or a counter-assessment of the details of the situation. Neither of us is rarefied: we remain concrete and particular. That active possibility has to do directly with the kind and amount of "space" that is available to her in her relations; that is, is a function of the formal features of those relations. In the former scenario, my daughter, is already entirely the recipient of a type and the rule that applies to that type. This occurs through the invocation of certain discursive fields into the "ponderous, formidable materiality" of childhood which changes the space in which she negotiates her life, before she has even found herself faced with particular moments of negotiation.

On this account, freedom does not involve the exercise of rights and conscious deliberations in accordance with a rational plan of execution toward an end. That notion of freedom is clearly dependent upon this one. Similarly, oppression is not fully described as a state of limited rights or lack of means or ends to organize deliberation around. Neither is it simply an individual act of coercion. Freedom and autonomy have to do with the relations which exist between an individual and the wide nexus of relations she operates within. They are about the relative extent to which an individual is actively able to direct and comprehend her own selfhood and behavior at a micro level compared to how much that is directed and understood in terms of macro relations which are brought to bear on that individual insofar as she is the recipient of a type. This directedness is a direct function of the kind of regime of power which the subject is 
operating with and upon. As we will see in the next section, different regimes of power offer different arrays of space of self- and other- directedness.

The ethical life consists in fostering that which is actively toward freedom and in discouraging violence. It involves negotiating an on-going position between the making up of a life as you go along and accepting from without (from other people, from prior depositions of intention, from things, from future goals) terms which give form to, which contain and define that life. From the point of view of that part of the on-going struggle which is the individual, it is about negotiating placement and connectivity amid relations of power.

The only ethical experience (which, as such, cannot be a task or a subjective decision) is the experience of being one's own potentiality, of being one's own possibility, exposing, that is in every form, one's own amorphousness and in every act, one's own inactuality..$^{\circ}$

On this view of freedom, the extension or multiplication of discourse is undesirable since it alters the potentiality not just of those "directly affected" (such as homosexual men and A.I.D.S. funding) but of everyone, based on their relations to a field; relations which may be conscious or unconscious, near or far, deliberate or accidental. Bringing a discursive formation to bear on an event for its interpretation is like creating what I will call "tautological space"2! The space of deployment is increasingly populated and gridded Minnesota Press, 1993:49.5; 99.2. "Morality, different than ethos, is about blameworthiness and repentence...shackling potentiality toward the past." contains two premises; each of which defines and is defined by the other such that the statement is hermetically true 
with points of affirmation and negation, which put all things into proximity and relation, such that any position a subject comes to affirm (even if that position is a refusal of a position), affirms overall, the bare facticity of the field. The invocation of discourse can make general truths, - universals, generalities, axioms - stand independent of, and prior to, the coming to it of specific concrete individuals and the events of their lives.

Let me try to offer as an example in support of my claim that discourse can be tautological, the following account of my own experience of the invocation of religious discourse of religion, the axioms of "a higher purpose", "meaning in all things", and "souls"- as oppressive.

A man fell in love with me. His reply to my lack of interest in him was that I was the one; I was meant to have encountered him, to save him, to help him move on to his next spiritual stage. His explanation for why he felt so compelled to see me and make a connection with me was that our souls had once been together in a past life, and were now just meeting again (i.e. that this wasn't his choice or mine to make) according to Divine Plan. My explanation was that he was attracted to me.2 He became so obsessed with me, partly spurred on by the convenient truths that his discourse offered him in support, that he actually began to invade my life (it bordered on stalking), and he would

and thus redundant. I am borrowing the sense of this for my description of how discursive space changes. It isn't just the case that it is more and more scripted. This scripting affirms more and more the premises which the scripting draws from to extend itself, thus there is the sense of hermetic redundancy here too.

22

I'm not saying whose account was right or wrong: I'm just pointing out the way that each of these accounts imports a space of negotiation for the other, and that the story of being sexually attracted has an enormously different space of confirmation and dispute than the story about salvation. One is a much more extensive and unilateral kind of violence. 
not listen to anything I had to say. I contemplated packing, moving, quitting my job, etc. When he realized that I was very upset and didn't want to have anything to do with him, he apologized for putting pressure on me to have sex, and told me he would give me more space. He even suggested that I was right to point out that "our purpose together" was something less crass than just having non-Platonic relations. This wasn't the problem. The problem was that having extended his discourse of religious truth to include me, there was no place I could go, nothing I could say, nothing I could be, which was my own account: even if I packed and left without a word, there would be nothing in that that would cause him to doubt the basic truth of his frame of reference: he would just say that too was part of what I was meant to have meant to him. For every discourse there is a cupboard full of personae. Of the characters available to his story, and I would just be another one of those: the unconverted, the lost soul, the virgin spirit, the one who challenged his strength. As I write this, I am still aware of being imprisoned in his narrative. I tried to tell him that his petulant demands to have sex were insignificant in comparison to his appropriation of me in my entirety to play a role in his larger truth, a role that I in no way invited or recognized myself in. As the words came out of my mouth, though, they weren't my own: each syllable struck a little bell in his script; everything I had to say he treated as a fantastic new moment of recognition, of confirmation. Something of that experience is probably identical to the experience of any individual caught in a web of someone else's generalized account of what kind of a thing they are and what each of their gestures means: a "hysterical woman", a "crack head", a "Jew", a "liar", young Rivière, an incompetent mother. I am making the claim here that 
the invocation by him, of the field of religious truth was an abstract but essential kind of violence against me. ${ }^{23} \mathrm{I}$ 'm not sure that this example proves that all discourse is undesirable, but it does point out the changes in form and mechanics which come about as a result upon "neighboring" discursive domains for navigating events, for making judgments about events.

Form, Discourse and Judgment

Discourse enables the passage of judgment. Freedom is the name of the active state which resists the issuance of judgment and the imprint of being judged. The subject of freedom is not only an individual; it could be a collective, a country, a period in history. It is a state of being relatively active as one comes to occupy roles: social, political, sexual, to adopt meanings about these roles, and to use objects and words to organize one's reality. It is about being or making the generalized Other ${ }^{24}$ Freedom is that which is contrary to a state of passivity in roles taken, meanings adopted, means and

Lévinas, in Totality and Infinity (1969), discusses religious experience and its relation to "the ethical" in a manner akin to what $I$ am describing here of more general experiences of limitation and freedom. There, he distinguishes two kinds of spiritual orientations, the holy and the sacred, as having radically different roles for the object (the transcendent) and for the subject of sacred experience, and thus radically different possibilities for ethical relationships. The "sacred" (a form of spirituality he critiques and rejects) offers "the temptation of temptations", the promise of an immediate escape from identity, transcendence for the individual, and personal contact with the Divine. Lévinas points out that this kind of a believer or participant in ritual can (and does) take every possible experience as confirmation of divine contact. The epistemology of the sacred builds in an existential affirmation for every possible affective state. The holy, by contrast, will not let the self make a truth of it, will not be slashed. Lévinas suggests that relations to "the holy", precisely in this resistance to coming under discursive organization, reaffirms the positionality of a self as individuated, as non-holy, and as among Others, which is where he thinks the ethical must be directed and practiced. Lévinas' account and mine are similar in that they describe how a resistance to a certain kind of overarching definition is necessary to create the space and freedom for action or resistance to take place from where it is actually located in a subject node.

24

686.

Kirin Narayan, “How Native is a “Native' Anthropologist?” American Anthropologist 95 (1993):671- 
ends ordered accordingly.

What makes this observation something more than generic is the important fact that not everyone or everything has the same capacity to resist or to issue judgment. A reasonable standard which enables us to make the claim that one person, $M r . W$, is more or less oppressed than a second person, $M r . B$, (without recourse to the language of power as possession of individuated beings) is the degree to which either of them is able to be an individual and not a foisted upon type. Or, conversely, when and where individuals claim type status for their own ends, the degree to which they are allowed to be a type, an ideal, rather than an individual. Where discourse articulates to a greater and greater degree, kinds of subjectivities, the range of freedoms available to an individual to remain uncontained, to remain an individual in body, mind, or identity, prior to the drawing out of generality, is altered.

The space of, the tempo of, and the order of relations between some particular incidence of something and the general truth about that incident is different for different sets of relations. This space, timing and order makes an enormous difference. The entry of the general truth reorganizes what will follow from it, and becomes the justification for extending limits to one situation rather than another, for entering one life or body or home at a certain time, and leaving others alone. To make this point, consider the death of Amadou Diallo. One aspect of this is that any given young black man is less and less able to be seen by white copes as an individual and more and more likely to be seen (therefore treated) as a type: criminal. The regular "spaces" in which young men behave has been infiltrated and recast by the discourse of race such that when a black man does the same 
thing as a white man, they each trigger unique sets of reactions. This lines up perfectly with a comment a middle-aged black male professor said to me recently: "the best thing you can teach a young black boy these days is how to take out his wallet carefully." It's not entirely clear that even "clearing up" misperceptions, or counter-balancing them with more accurate humane ones presented to or by African Americans (scholars and otherwise) won't simply extend the same violences; in this case, those violences expressed as racialized trends. ${ }^{25}$ The will to knowledge, even bent towards the service of social justice (anti-violence movements), may not evade the kinds of deeper violences which the expansion of discourse supports.

the historical analysis of this rancorous will to knowledge reveals that all knowledge rests upon injustice....and that the instinct for knowledge is malicious (something murderous, opposed to the happiness of mankind). ${ }^{26}$

If the formation of discourses ought to be resisted then likewise the formation of positive subjectivities "offered" by discursive fields as power/knowledge relations ought to be resisted since these subjectivities, in their third function, anchor or extend the formation of discourse. Foucault on many occasions explicitly claims that the uptake of specific subjectivities amount to, or invite violences. In "Nietzsche, Genealogy, History", he claims that historicization (the assembly of events into a sequence under the discourse of

See Jeffrey Goldberg, "The Color of Suspicion: What Cops Talk About When they Talk about Race." New York Times Magazine (June 20, 1999):50-64;85-87.

Michel Foucault, “Nietzsche, Genealogy, History."(1984c:95). 
"history") requires and makes use of the lived body of its subject-matter in a "process of destruction". ${ }^{27}$ From Foucault, then, we hear that the violence of subjectivities must be and can be resisted. Subject formation organizes two levels of containment. There is the micro role it plays in normalizing any particular field (offering a specific standard of knowledge according to which persons are standardized) and the macro role it plays in facilitating the general violence of containment. Subject positions offer a formal structure to discursive fields and in this play a role in instituting "the form of the rule" from which the possibility of standardization and judgment come into play.

\section{Freedom From and Freedom To: Resistance and Subjectivity}

However, consider that if the subject is a nodal position from which containment can be better effected, it is also the case that the subject is a nodal position from which containment could be resisted. One is never entirely free from discourse, just as one is never entirely "free" of power. Relations are always "enseparable, overlapping and entangled". ${ }^{2 k}$ One is never entirely adequate to a form of subjectivity, just as one is never entirely inadequate to a form. As was the case with power, negotiating subjectivity and its relative freedom will not be a question of taking it or leaving it, but of using it strategically to alter one's capacities within, between or among overlapping discursive fields. It isn't a question of not being in relations of power, but in not being in

(ibid:82-83). 
pathological and dangerous relations of power. ${ }^{29}$. According to my analysis, pathological or dangerous refers to how one may be more or less contained; more or less free from judgment or what Foucault calls "domination". Freedom of the self is not freedom from relations, but effective practices of resistance within these relations:

I don't believe that there can be a society without relations of power, if you understand them as means by which individuals try to conduct, to determine the behavior of others. The problem is not of trying to dissolve them in the utopia of a perfectly transparent communication, but to give one's self the rules of law, the techniques of management, and also the ethics, the ethos, the practice of self, which would allow these games of power to be played with a minimum of domination". ${ }^{30}$

But, what this domination is "inside" relations of power is not easy to say, since, for instance, it is possible that the uptake of a subjectivity (a violence or a containment of randomness) increases ones embeddedness in relations, yet this very thickening of relations allows one to be more active amid another's. Containment is, relative to an outside, a loss of freedom, but relative to relations of interiority, a kind of intensification. Moreover, this intensification of relations or movement toward interiority isn't taken up merely as a means to enable uncontainment. Or, to put it another way, people don't make relations (of meaning, of identity, of need) with other people and with things so that they can define themselves all the more clearly against these. They do this because there is a

Michel Foucault, "The Subject and Power." afterword to Michel Foucault: Beyond Structuralism and Hermeneutics. Eds. Hubert Dreyfus and Paul Rabinow. Chicago: University of Chicago Press, 1983a:232.

30

Michel Foucault, "The Ethic of Care for the Self as a Practice of Freedom." Trans. J.D. Gauthier and S.J. in The Final Foucault. Eds. James Bernauer and David Rasmussen. Cambridge, Mass: The M.I.T. Press, I994b:18. 
way in which freedom (and other goods like beauty, care, connectivity) is tied up with these relations.

Expanding on the base notion of "containment" then, a lexicon of critical terms must be built up to adjudicate between realities "inside" and "across" discursive fields as more or less dangerous or pathological. We need critical terms which admit of the way one thing can both be toward violence and away from it. Political and ethical affectivity is about the possible strategic (re)arrangements of power/knowledge. The possibilities of resistance and oppression are directly related to the ways that different fields of power arrange different positions for subjects, hence, different spaces of judgment.

Moreover, as I have already discussed at length, the diagnostics and what is diagnosed do not stand in a relation of externality, but are mutually immanent in relations of production. For Foucault, resistance is primary and positive. ${ }^{31}$ For Deleuze, Life and difference are primary. ${ }^{32}$ Freedom/Life are built into power as a mode of positivity available under certain internal conditions rather than an independent space created by an externally-derived negation (Death/stasis). ${ }^{33}$ The place where defence starts and offence

(ibid:2-3;12-13). Society for Phenomenology 24:1 (January 1993):3-14.

33 $61-80$

Paul Patton, "Conceptual Politics and the War-Machine in Mille Plateaux." SubStance 44/45 (1984): 
ends, where reaction starts and action ends, is indiscernible from the vantage point of formal structures. ${ }^{4}$ The way up and the way down are one and the same...in the circumference of the circle the beginning and the end are common. ${ }^{35}$

This is not to say that it is impossible to understand and "to adjust the mechanisms of power that frame the everyday lives of individuals"36 from "within" those relations.

In the next section, I am going to analyze Foucault's "regimes of power" in terms of their formal features. In the final section of this chapter, I will return to the topic of property, using this map of power, to assess whether and how the expansion of the discourse of property increases or decreases freedoms, and relatedly, to discuss what resistance might entail.

\section{Cartographic Analysis of the Formal Features of Foucault's Regimes of Power}

Foucault's own genealogical projects mapped three major cartographic functions

34

On the indistinguishability of war from peacetime, see Brian Massumi, "Requiem for Our Prospective Dead: Toward a Participatory Critique of Capitalist Power." Deleuze and Guattari: New Mappings in Politics, Philosophy and Culture. Eds. E. Kaufman and K.J. Heller. Minneapolis: University of Minnesota Press, (1998):40-63; Jean Baudrilliard, La Guerre du Golfe N'a Pas eu Lieu. Paris: Édition Galilée, 1991; Thomas L. Dumm, "Telefear: Watching War News" The Politics of Everyday Fear. Ed. Brian Massumi. Minneapolis: University of Minnesota Press, (1993):307-321.

1966:78.

Heraclitus, Fragment 108 \& 109, The Presocratics, Ed. Phillip Wheelwright. New York: Macmillan,

36

Foucault (1979:77). 
which he called "the discursive rules". These "rules" refer to the mechanics of discourse, whether discourse is forming or operating or devolving. Those are: "enclosure", "partitioning" and "deployment". We can bring together his positive political and ethical principles ("uncontainment") with his more abstract ontological analyses of power. These key terms "enclosure", "partitioning" and "deployment" are generic rules which apply across all level of function, not merely to concrete subjects in particular locations. These three major cartographic functions ask after: that which moves in, that which keeps in, that which moves out, that which keeps out, and that which establishes and stabilizes these configurations relative to one another, including their distances and intensities. Different domains of power organize these formal possibilities differently. Thus, each of these regimes of power suggests a different schema of violence and freedom and nominates a different ontological relation for subjects. ${ }^{37}$

Power is the substrate from which all facets of the social reality are fashioned. Social realities differ in many respects, one of which is their formal characteristics. Examples of formal characteristics are equality, distributions (juridico, material, geographical), plurality, reciprocity, hierarchy, harmony. The formal characteristics of a particular social reality, however simple or complex, vast or minute, are an expression of a particular regime of power which dominates that reality. Four general power regimes can be distinguished: The territorial segment, the Juridico regime, the Normalizing

As I describe those relations, bear in mind that what I am doing is setting up a general descriptive scheme according to which, we can makes some general evaluative observations about freedom and oppression; eventually, in order to be able to make evaluations about the relations between freedoms and specific trends, such as the shift towards increased privatization of ideas. 
regime, and the regime of Biopower. Foucault identified the latter three, calling these "power set-ups". On my account, what distinguishes one power regime from another is not its methods of deployment, nor its content, but its form. Each regime of power tends to stabilize, and is in turn stabilized by, a relational array, or what Deleuze calls "cartographies". .3s

Individuals within these tend to have available to them, and to be enmeshed in, certain kinds of relations. These relations, precisely by virtue of their unique formal features, will have different degrees of latitude or flexibility. Each has different zones and types of what Foucault called "legalities/illegalities". Freedom is at least partly about accessing and making use of these zones in order to direct or to be directed. Each combination of subject position, discursive field and forms of power will present a unique tactical challenge, formally speaking.

...tactics which, becoming connected to one another, but finding their base of support and their condition elsewhere, end by forming comprehensive systems. ${ }^{39}$

The strength or viability of a particular promise regarding expanded "freedoms" or threats to freedom referred to in any particular political discourse ("the local... restricted..

Deleuze (1988a:23-44).

Foucault (1980a:95). 
cynicism of power") +0 can be, and should be, checked against this "deeper zoning". For example, the increased personal freedoms which have been suggested as the upshot of the advent of on-line life, may or may not deliver, depending upon how alignment with these underlying ontologies.

Also, each regime of power tends to manifest a certain style of directive. Styles of directive, as we will see, help us to understand better how formal features are related to the kinds and possibilities of judgement. Power is directive: intentional and yet non-subjective."1 Foucault denies that each causal shift can be traced back to an intentional subject administering directives. He insists that even without this base in an individual's motivation, we can say that there is nevertheless a discernable "aim" to power. One way to think about an "aim" without an "aimer" is to think about the way the relations themselves are organized and mobilized, as being directed and as having direction. Foucault calls power "the over-all effect that emerges from these mobilities." $\$ 2$ We could call this "over-all effect", this "intentionality" its style. Its style is a function of its force and its direction(s).

Individuals understand their relations in and as modes of power differently from

(ibid:95).

41

(ibid:94-95).

42

(ibid:93). 
one regime to another, by virtue of the different styles of expression that power regimes have. Power is not strictly repressive or coercive; that is, has an aggressive style which pains, repulses, takes away or makes wary. Power is equally able to find expression as affirmation, pleasure, comfort and intensification. Again, these possibilities of expression are dependent upon the formal features of the domain of power; the particular styles of the relations of power include styles of the spaces, styles of the lines, styles of the nodes (subjects) which constitute a particular domain. By no means do regimes of power exist independent of one or evolve through a predictable series, but, I believe, can be found juxtaposed within any given social frame. What may be true is that certain regimes of power dominate a given social field. ${ }^{33}$

I will now examine those features of the four regimes of power.

\section{Early power regime formation: The Territorial Segment}

The territorial segment is any space produced by the enclosure of an inward-folding borderline. Discursive production can be imagined as the early stages of formation of a territorial segment. The borderline, the early limits of a field of power, may be more or less undulating, more or less permeable. Moreover, such a territory may or may not stand in a productive relations to an invested nodal focus (or in the case of the ellipse, to two foci): its primary productive relations may pass asymptotically (adjacent) to an outer limit. "What comes to this field always comes from without, rushing in three regimes: the sovereign with pre-modern, the normative with the modern, and the disciplinary with advanced capitalism. I think we could find instances of all three in any given social milieu. 
through their opening." As an undulation in shifting formation with non-stable internal points, any element of an early matrix stands in a relatively undetermined number of power/knowledge relations to any other element.

We do not need to assume that there is a paucity of elements in the matrix and that this paucity is responsible for the low tension development: the form of the regime is entirely a function of the cartographic relations between elements, between individuated and ground, not their density. An irregular, asymmetrical and local nature dominates. This regime of power corresponds to the organization of relations of desire and production which immediately follows the full body of the earth,

...a unity of desire and production, the indivisible entity, the unengendered stasis, the element superior to production that conditions the common appropriation and utilization of the ground."As

It is a field of power just beginning to organize a discursive field. As form, it is an amoeboid or irregular style of territorial segmentarity, made up of "segments of varying lengths". ${ }^{46}$

Though not systematically, this formation offers the highest possibility of

Deleuze and Guattari (1983b:152).

45

(ibid: 140-141).

46

(ibid: 152). In the next section I will examine Deleuze and Guattari's account of this form, the rhizomatic line, in greater detail. 
freedom in its formation of "vacuoles" and "illegalities"'. Regarding this illegality:

Roughly speaking...each of the different social strata had its margin of tolerated illegality: the non-application of the rule, the non-observance of the innumerable edicts or ordinances of were a condition of the political and economic functioning of society...illegality was so deeply rooted and so necessary...that it had in a sense its own coherence and economy.+*

Illegalities here are possible, formally speaking, as: oddly shaped pockets of invisibility, unlinked elements easily forgotten, not yet named/marked or the as-yet-useless, zones of accidental and deliberate non-participation, accidents of recognition. Prohibition is not, cannot be, evenly distributed or systematically applied, except "to those who, in a given state or on a given occasion, are deprived of the right to enjoy a collectively invested organ." Prohibition, then, in this regime of power, is not tied to rule of law and through a system for equivocation and exchange of punishment, but (when it operates), is direct, non-iterative. If the rule of law can be established here, it would function to prohibit, but in this regime, is not the paradigmatic case of it. This suggests that the primitive territorial segment organizes an ontology which does not support a complex of judgment and being judged, but does support, indeed $i s$, the judgment which is inscription.

When direct judgment (marking) occurs, it is entirely unilateral (non-exchangist)

47

Gilles Deleuze, "Control and Becoming." Negotiations. Trans. Martin Joughin. New York: Columbia University Press, 1995:175.

48

Foucault (1979:82).

49

Deleuze and Guattari (1983b:142). 
and unconstrained, permanent and "with a maximum of vigilance and extension, binding [them] in a system of cruelty...."so although the debt it links to an individual is "mobile, open, finite".s" Incommensurabilities and inequalities are permitted as formal features of this system. ${ }^{52}$ There is more freedom from judgment, yet when it occurs it is more direct and severe. However, it can be negotiated, paid down in full or shunted.

In such a segment only minor complexities, codings or iterations, divisions and excisions, occasional invaginations of external elements or expropriations of internal elements, are possible. Thus, power relations, organs, mental or affective complexes ${ }^{33}$ (therefore memory) are not privatized. The familial is coextensive with the social field ${ }^{s}$. It is an "intensive, non-personal regime".ss

If there is a subject of property it is strictly the body itself, organized sometimes

50

(ibid: 184).

51

(ibid:192).

52

(ibid:187).

53

(ibid:166).

54

(ibid:176-7). This coheres with my earlier account of the shift in Kwakiutl social arrangements from collective quarters to small, personal houses, and the correlate increase in distinguishing lineages.

55

(ibid:162). 
as the property of one person, sometimes the property of its bearer. ${ }^{36}$

The overall style of directive is polyvocal and non-restrictive, neither fully augmenting nor oppressive, neither fully communal nor entirely intimate. There is a "system of evaluations possessing the force of law concerning the various members and parts of the body"s?, there is a cruelty in the organization which traces its signs, "its terrible alphabet" directly on the body. In this regime there is a pervasive fear of [re] dispersion"s , there is a "mournful and morbid foreboding of things to come." 59 Yet, there is also an affirmative expression in identification of like and unlike others as distinct or as filial.

The Sovereign, or Juridico Regime

There is a second identifiable regime of power in Foucault which identified as the "Sovereign" or the "Juridico". Deleuze and Guattari identified this second formation as the "Barbarian Despotic Machine". Increasing rigidity in the undulations of the territorial

56

(ibid:157).

57

(ibid:144).

58

(ibid:153).

59

(ibid:152).

60

This is not to be confused with the sovereign subject of a domain, discussed earlier. Here, the term "sovereign" refers to an external, singular, pole of authority, such as is well illustrated in a King. 
segment stabilize a more geometrically regular formation. It is not yet a fully closed system. Geometrical regularity is the result of power relations becoming isometric, and reorganized such that they each pass through a depositional point.

With the Greek city-state... a homogeneous and isotopic space appears that overcodes the lineal segments, at the same time as distinct focal points begin to resonate in a center acting as their common denominator. ${ }^{n t}$

Here, power relations are extremely concentrated around a single unique office, or a common figure of endowed authority/agency (like a King). This "One" is a cartographic center, invested with causal (temporal and spatial) relations to all the rest by virtue of the stability of the form of the One compared to the instability of form of the Many. The sovereign pole (God, Unmoved Mover, le nom du Pêre) is the only identifiable, stable locus: everything else stands in vague but real relations to it. It is this "standing in relation to" which makes a central point inhere and stick as a causal focus on a power grid. Simultaneously, power relations are highly dispersed among generic "subjects" who do not recognize authority and agency in themselves, nor are they recognized as authorities or agents.

Even though every element stands in some relation to this center, these are not necessarily symmetrical. When these relations are topographically mapped, we see a binary relation (Yes/No) but not a true dyad $(0 / 1)$. The perimeter is still ragged. This means that this regime is not structured by its peripheries. These peripheries are asymptotic as we approach more and more concentrated power (in the pole of the King) 
and less and less articulated power (in the zone of the endless masses). It is because of this distribution that we tend to say, of power, that one "has" it, and others "lack" it. This relation's chief defining structure is a central zone which approaches a line of division.

This model of power best approximates the common notions of power and poweriessness. Oddly enough, though this regime of power is closest to Monarchical rule, it is also taken up as a true and appropriate model of power in a modern, democratic society, echoing what we saw earlier in terms of Locke extending, rather than truncating Filmerian power's ontology.

There are two important features of this regime of power. The first is its style of operation. Foucault tells us that the voice of this regime is the voice of law and prohibition: the voice which says "No!". What this means is that the kind of authority which the King (or the father, or set of rules, or whatever or whoever occupies the sovereign pole) has "over" his subjects consists for the most part in setting out rules for what they must not do. Giving specific instructions, laws, indictments, prohibitions which characterize and locate the margin between the Kind and his subjects, the line that subjects cannot cross without drawing out the King's power, the power which always expresses itself in the style of a directive or denouncement, "No!". Right and wrong are clearly indicated or embodied. What is important about this form for our purposes is that one can position oneself around these rules, by knowing them and then negotiating them.

Typically, the King demands the death of his subjects as absolute penalty for transgressions. This is a serious consideration. But, although this is a line of negation, it says "no!" episodically, and with variations of pitch. The second feature of this regime, 
related to the first, concerns its zones of licence. These zones may be physical or psychological. Although it is not a common way of depicting the state of being under feudal law, or the state of childhood under a strict, authoritarian father, Foucault provocatively suggests that this rigid, binary structure of power relations creates, in effect, an enormous zone of freedom for who we tend to identify as the "powerless ones" in such a regime. What the King stands in relation to, and can extract by virtue of his power, is not the everyday Lives of his subjects, but only, potentially, their deaths. Since each and every rule is not, let alone cannot be expressed, and even when expressed, enjoys a hermeneutic gap between its expression as law and its instantiations in infractions, many aspects of a life simply do not fall into the dialectic of judgment and control. Short of trespass, the subject of the Juridico regime enjoys what are in fact certain latitudes. I witnessed this all the time in an Islamic Fundamentalist country: though the West tends to sell itself as the kind of political culture which increases the freedoms of individuals living under its democratic structure, when you look closely at non-democratic states, there isn't an absence of freedom: it is distributed quite differently. The structure of rule of law hasn't been replaced by the non-binary supple and complete field.

\section{The Normalizing Regime}

The third regime of power Foucault calls "Normalizing". It proceeds from the emptying of the sovereign focus, actually, symbolically or historically. Freud's story of the passage from "primitive" to "civilized" Man in Totem and Taboo is a cartographic account of the passage from primitive territorial segment, to Sovereign domain, and, 
through the fraternal murder of the despot, to a normalizing regime. This is about his story of normalizing the Ego to civility. The same cartographic changes are also encountered in the Socratic drama, in the becoming-Athenian inauguration which makes possible modern judicial practices. According to Freud's tale, the elimination of the despot -- who is a despot precisely by virtue of the formal arrangements that he is -- takes place according to an organized circulation of common intent along the perimeter of the previously random elements of the sovereign regime socius.

This same structural change, in public and in private relations, is required for the passage from primitive to civilized culture, analogically, the passage from child to adult state. The structural changes result in a "pulling in" of the ragged perimeter such that each and every subject stands in a symmetrical, equivalent relation of complicity to the act of emptying, the killing of the King. All segments or relations of power are roughly equal and are constantly adjusted in order that all persons might enjoy a similar positioning (even if only abstractly). Every one is, on this regime, independent, free and equal. The shift from despotism to modern democratic state depends upon this cartographic induction. This regime maps out a perfect circle: there is a central position, but it is not occupied by any one person or authority. ${ }^{62}$

It is not occupied since the legal and ethical principles and the psychologies of fraternité and égalité depend upon this perfect circle and its emptiness. The construction and maintenance of a perfectly circular territorial segment depends upon a common

Cartographic analysis disrupts historical narratives of progress since, in observations like this, monarchy and democracy are found in the same regime. 
intensity. In Freud's story, that intensity is mutual guilt. Each is equally indebted to the killer or the converter.

That the original Father is killed (and must be re-killed, continuously) by any and all Brothers makes two subsequent cartographic gestures. Each member stands in exactly the same relation both to the emptied hole and to every other member of the new collective. Right and wrong consists now, in knowing and maintaining positioning rather than (or before?) the knowledge of rules. Fraternité and égalité are the formal arrangement of radial symmetry. Radial symmetry is the formal condition of modern justice; its procedures of judgment respect and reproduce first and foremost these relations.

The hubris of having appropriated to the self some force from the King-position inaugurates the possibility of Anyman occupying the node previously occupied by the Sovereign himself. The guilt and the debt are as pervasive as the threat of reversion to Sovereignty. This threat (or promise) is inscribed across all members' bodies and belongings because they are willing and able to identify themselves to each other as rightful (co-conspiring, colleagues) members of the Fraternity. This cartography aligns social investment into new equations between visibility and suspicion, as well as codes of gratitude and fairness. If a threat or promise is not recognized as inhering in any particular individual, it may be precisely because they have not been properly marked and so are not recognized as (and thus do not recognize themselves as) general subjects of this 
regime. ${ }^{33}$ This would be a good instance of the power and protection of "type" not being extended to all. Or, relatedly, an individual may not be recognized as collegial because they embody, in a kind of subjectivity, the very principles against which the fraternal contract necessarily forms. Or because the so-called abstract individual -- the liberal subject -- who occupies the center has not been adequately conceived of in order to be inclusive. What I am suggesting here is that one formal features of a normalizing regime is the articulation of a perimeter within which a certain type of individual can be included and outside of which other kinds can be excluded. Thus, even where it appears that the removal of a despot, and his replacement with a generalized subject will increase overall freedoms, if we look at the formal features of this shift in power regimes, we discover that it installs a cartographic system according to which only certain kinds of persons are able to enjoy that promise. This helps to explain Carole Pateman's claim that,

The fraternal social contract story shows that the categories and practices of civil society cannot simply be universalized to women. ${ }^{\text {th }}$

Since a comprehensive set of relations with the whole is the pre-condition for the exercise of any promised freedoms, standing "outside" this arrangement does not carry the same range or quality of freedoms that was possible in the first or second regimes. The positioning and the visibilities of this normalizing regime inculcate the permanent dual 1989:33-57. 
possibilities of judging and of being judged. This is why it is called a normalizing regime. "Men judge insofar as they value their own lots...[T]hey judge and are judged at the same time.....5

On the other hand, there is a beauty and a positive intensity to this circle and what holds its center. What does occupy the center, the anyplace where judging power relations operate, is a norm or an ideal invested continuously by those in position to it. This norm, unlike the Law of the Sovereign, does not say "No!" once and for all. It is less an anchored Right and Wrong than a procedural and on-going evaluative series. It says "almost" and "not quite" or "that's enough now". Individuals continuously take up, or are allotted to, degrees of distance from the ideal, whether it be a standard of intelligence, racial purity, or civic mindedness. This form of power has converted the binaries of Rule of Law into the radiality of Common-to-the-law, which has a unique schema of freedoms and responsibility.

\section{The Regime of Biopower}

The final regime of power is "Biopower". It is not a new regime, though it is an expanding regime. It is structurally very similar to "Normalizing" Power, with two important changes. While it retains the model of circle and center, it multiplies these such that each individual is both a center of authority and the entirety of the circumference of it. The dominant relations of power are not between persons (intersubjective), but internal and Michael A. Greco. Minneapolis: University of Minnesota Press, 1997:129. 
to the negotiation of Self (intrasubjective). Where they are between persons, the object of judgment or the space of freedom is the body, rather than the soul of the other. ${ }^{66}$ Where previously, the body used to be understood as the vessel for the true seat of the person, their soul, under a Biopower regime, the true seat of the person is their biological selves. A person is essentially their phenotypic and karyotypic health; their relations of affirmation and negation are tied up in what they are and what they could be, bodily. This regime organizes a micro set of power/relations around the self's knowledge of its bodily potential.

Biopower/knowledge relations are largely located in organizing bodily comportment and desires, adjusting the flows of biology to a variety of containments. The human body, more than the relations between bodies, performs, as a spatial function, as a highly useful anchor for marking and reading performance of lawfulness and unlawfulness.

Bodily matter is directly and immediately caught in a field of power effects and mechanisms for whom legislation, when not archaic, is simply redundant. ${ }^{67}$

The feedback loops adjusting deviance and normalcy do not rely on external mechanisms of surveillance. Neither do they require an external set of rules and a relationship with an authority who will administer those rules. What constitutes the framework of judgment,

Foucault (1979:30)

67 Braidotti (1994:52). 
of right and wrong here? In what does excess, or freedom from defect lie? Is it: 1) an accidental trespass, 2) a set of authorized rules, 3) a code of mutually agreed upon standards and procedures for maintaining group form? It is none of these things. There is no "center" to the individual which establishes the substantive standard to which he or she should adjust her body. There is no baseline co-positionality which dictates a reasonable allotment or distribution of goods, therefore frames a set of substantive procedural requirements.

There is only the principle of judgment itself in continuous operation: what is right is that which is actively adjusting, developing competencies per se; what is wrong is acceptance and refusal to develop competencies, or the attitude of inattention to selfregulation. The interiorization of a sense of justice produces highly centered subjects through the practices of self-regulatory mastery of bodily norms: the bureaucrat who is able to define his position exactly between the position of being threatening and being threatened. The ideal subject here, the competent individual is inclined to, and able to function in a highly contained manner, one scale removed from relations with others enabling this functional adjustment. This subject is a highly dense and self-contained spot within a discursive field. This subject "carries" the virtues and values of modesty, selfrestraint, utility deep within the socius.

Deleuze and Guattari's describe this uptake and spread of biopower as "the Eye of Power" (which was what the normalizing social order emptied out) taking up residence 
and resonating in a million possible microsites. ${ }^{68}$ In Freud's terms, the Superego has become internalized, allowing the individual to function in society, as a civilized, social being, in the absence of either a figure of Authority, or even a cue recalling the conversion of that authority to the group. ${ }^{69}$ The "phenomenon of conscience reaches a higher stage" ${ }^{70}$ It does so because of the formal realignments which inhere in this form of power: a dense sphere tends to close, rather than widen, the gaps between Self and Norm, and this arrangement continues to invest inward lines of becoming in further expressions of competency. It creates a closed-circuitry. Deleuze and Guattari call it "totalitarian". This "civilizing cartography" results in increased transparency, a decrease of previously sustained vacuoles of secrecy and deviance (one's thoughts now not only one's actions, are subject to censure); that is, ultimately, a sharp decrease in individual freedom and a correlate increase in containment which serves to stabilize the entire field of the socius.

Relatedly, the second difference between this regime and the former has to do with how an individual experiences these relations of constraint. I have suggest that these relations of constraint are more extensive, but with what style? According to Foucault, this mode of power as a regime of operation has a tremendous allure and high degree of

Deleuze and Guattari (1987:210-214).

69

Sigmund Freud. Civilization and its Discontents. Trans. and Ed. James Strachey. New York: Norton, 1961:Chapter VII \& VIII:70-92.

70

(ibid:72). 
uptake because the normalizing function is continuous, intimate and has taken on a strictly affirmative tone. The style is affirmative, announcing only on-going successes of mastery, not failures of obedience. It says "Yes, Yes, Yes!". If and where relations with a third party are taken up, these are often as aides to continuous positive assessment of progress toward physical or mental health.

Individuals...may present themselves as someone who "follows doctor's orders", who is a "good patient", working actively in the medical encounter to achieve this...the individual has a personal, emotional investment in presenting her- or himself in a certain manner, as a certain "type of person" engaged in "rational" and "civilized" behavior...."

The seat of authority is Self, but Self broadly investing in what appear to be self-chosen relations of surveillance with apparent supportive helpers, others who are no longer conceived of as adversaries.

The old power of death that symbolized sovereign power was now carefully supplanted by the administration of bodies and the calculated management of life. ${ }^{2}$

The style of directive invites little caution or suspicion toward uptake of subjectivities and regulatory programs, or toward the extension of surfaces of surveillance to third parties. A classic and tragic case of the biopower taken to the height of its capacities for co-mingling freedom and constraint, docility and affirmation is the case of anorexia nervosa in young women. This invokes my earlier discussion about the subjectivities York: Routledge, 1997:105.

72

Foucault (1980a:139-140). 
available to women, and the deeper limitations these uptakes carry with them. This

excerpt from an interview reveals something of the addictive nature of the affirmation

that arises when relations of self are reorganized under Biopower's regime:

...the power I felt when asked by Dr. $K$. to register on the body size meter how large I thought I was. As I moved the lever a ridiculous distance out I watched his reaction from the corner of my eye. His expression was "Boy, this kid is wacko!" and all the time I knew what I was doing manipulating him and it gave me enormous pleasure. ${ }^{3}$

Instances of self-mastery (over impulses to eat to much, over levels of excitement and concentration, over not stealing something that could be stolen without detection, over recalling past abuses, over reproduction, over boredom and low productivity) are infinite number -- a whole life of potential zones to open onto the possibility of actualization, of self-directedness. Weight, smell, longevity, posture, genetic (karyotypic and phenotypic) health, buccal hygiene, offer/demand themselves as the manifold immanently-achievable zones of personal identification and expression of self-control.

Moreover, since Self is the biological actual and potential, control of self (ethical or unethical activity, political responsibility or irresponsibility) comes to include taking action toward the bodily/mental health of the next generation. All this makes the health of the individual the central recipient or target of public and private duty, which helps to explain the exponential increase in "therapeutic measures" since World War II."

Liz Eckermann, "Foucault, embodiment and gendered subjectivities: the case of voluntary selfstarvation." Foucault: Health and Medicine. Eds Alan Petersen and Robin Bunton. New York: Routledge, $1997: 157$. 74

Carolyn Wood Sherif, "Bias in Psychology." Feminism and Methodology. Ed. Sandra Harding. Bloomington: Indiana University Press, 1987:52-53. A related observation is U.N.I.C.E.F.'s recent response to the escalating violence in the Middle East, to fund counseling for the children of violence. (Globe and Mail, November 23 $\left.{ }^{\text {rd }}, 2000: A 2\right)$ 
"Biopower" reduces an individual to their mental and physical health, and in this, alters the civic circumference which existed in a Normalizing regime:

...the emergence of clinical psychology...after World War II reflects the fact that wars are very hard on people, creating problems that last far beyond their duration....the definition of what is to be done with human problems in living changes: many now required, not friends, not better working conditions, not a social worker, not a job interview, not a minister or a loving parent, but a therapist. ${ }^{75}$

The formal features of this regime of power offers us a glimpse of a cartography of Self, judgment, freedom and affirmation which provides an answer to the question "how does someone desire and participate freely in their own oppression?". It also offers us a view of the how systems of oppression can and will enter into and work with what appear to be systems of increased autonomy. Whenever the surface of, or the mere gestures of a body are the medium upon which relations of ownership/trespass, criminality/deviance, harm/healing are tracked and inscribed, in other words, where meaning and identity are negotiated, this regime of unique violences are enabled. In the previous chapter, I indicated how property claims for particular gestures ("the One-Click") have already been established. This is a good example of the way a procedure which at one level promises expanded freedoms (shopping from home via the web) puts the body itself through a sequence of gestures which place it in trespass, which require, of that same body, an additional number of steps or gestures to remove it from a position and state of

(ibid:53). 
contravention.

The more that an individual is "empowered" within a grid of therapeutics and self-surveillance, the less they connect actively or are actively connected with social and political (interpersonal) nodes. The affirmative style of this regime of power neutralizes the force of negation and our capacity to be critically aware of and hence choose or resist social relations. Also, this regime of power cultivates containment as interiority. To connect this with our earlier assessment, it expands the purview of the personal such that "the public" lies further and further from personal concern. Foucault's legitimate worry was that at the height of his or her empowerment, the successful bioempowered subject is simultaneously in a highly useful state or position for the fulfillment of any number of other projects. He had in mind the way that bioempowered individuals, eager to "administer life" toward small personal perfections in their own microzones, inadvertently and unwittingly support macropolitical projects like eugenics programs. Moreover, the structure of biopower ensures a "distance" between the micro and the macro that the means or impetus to reflect critically on these relations is diminished. ${ }^{76}$ I have in mind the role of "research subject": that just as we saw in the case of fetal heart monitors, the very presence of kinds of drugs and modes of medical intervention will require subjects whose roles is to affirm the capacities of these techniques to affirm. More and more frequently, in small and large measure, we will be expected to proffer ourselves to drug and therapy experimentation as part of our treatment, as part of our continuous

Foucault (1980a:135-159). 
performance of competencies in newer areas of our bodies. Outlaws, anti-social, antiideals will not be people so much doing the wrong thing (substantively) but the ones not following procedure. Shifting the focus of justice from substantive to procedural issues has ramifications for social justice since the capacity to follow procedure requires that one be, as a minimum, privy to power/knowledge relations through which one can both understand what is required and access the means to follow procedure correctly.

A related violence has to do with the limits of a mortal imperfect human body to fulfill the task of achieving a position of freedom via confirming an ideal of fully competent. This concerns what we might call "the cartography of blameworthiness". If the failings of an individual can be read in their bodily conditions then those in the most unfortunate bodily conditions, past, present or future, will find themselves placed under the sign of deviants. Unlike tying trespass or blame to the actions of individuals or groups of individuals, their physical natures invite it. This is nothing new. Tribal war is the manifestation of love and hatred attached, alternately to those who appear, or have been convincingly suggested as adequately physically like or unlike. ${ }^{n}$ However, recall how, in the Normalizing regime, we saw that, by virtue of the mechanics of formation of the perimeter and deposition of the (empty) center, some individuals are not recognized or do not recognize others as privy to the goods of a civil society (and privy to its duties as well). In the Biopower regime, the mechanics of formation of the circle of duty and 1995):78-95. "The European colonizers favored the architypically taller, lighter-skinned Tutsis over the Hutus. In the nineteen-thirties, the Belgians established an identity-card system that was effectively a form of apartheid."(89). 
obligation operate entirely around perfections of the (Self's) body, and judgment operates entirely according to deviation from this center. The locus of attention is directed toward smaller and smaller parts of the whole, and therefore away from establishing likeness or common-relations across wholes, let alone among a whole made up of these same wholes (the liberal state). What this suggests to me is that others are more and more likely to be recognized as, and judged as general rather than concrete Other. I already discussed why and how this is a form of violence. This likelihood arises from the fact that the human physical body, first among gender, then racial groups, is something which differentiates rather than effaces difference. In the absence of another locus of attention (a social concern) uniting and overriding the locus of attention of personal bodily concern, Others can only strike us as, by degree, less and less the proper objects of our concern and more and more the recipients of judgment of deviance. In this respect, biopower is socially and politically dangerous against a background of emerging tribalism and increasing civil unrest the world over.

Finally, and perhaps most importantly, concerns the way in which a regime of Biopower offers no zone of non-participation to a person. The capacity to opt-out requires a space where one can be neutral, ambivalent, detached, free from discursive play. Biopower is the discursive field of all organic life, where all possible relations between a living thing and its status as that living thing precede its coming-to-be. It is no longer a question of being a certain kind of Life, a measure of bodily health or neglect, a standard of beauty or monstrosity which "positions" a subject as subject to Biopower. Merely being alive means being subject to judgment; is something that demands an answer in 
defense, an adjustment, a justification. A regime of biopower sets outs relations such that there is "[N]othing...left but judgement."

Perhaps this amplified matrix of judgement could, under the right circumstances, be precisely the right kind of tool for ensuring social safety and justice. It is not that judgment is a bad thing. My concern is how the space that judgment can occupy is related to the capacity for subjects who "anchor" judgment (both about themselves and about everything else) to be able to resist or to take up relations of discursivity. As I have argued, relations of discursivity augment the level of order or containment, and decrease the levels of disorder or freedom from containment. The regime of biopower opens the physical body onto a zone of heightened self-regulation which can operate, effectively, to ensure a level of utility and stability and co-operativeness among bodies even in the absence of third parties who regulate bodily activity by Rule of Law. Based on my analysis of the formal changes in spaces of freedom and oppression which accompany this shift in power regimes, it is difficult to see how what appear to be positive scenarios of amplified personal autonomy are not, necessarily, at some deeper level, diminishing of overall autonomy. The kinds of scenarios, then, within which I might conceive of biopower as good and necessary are any in which personal autonomy (as I have described it) is a lesser good than something like public security, where public security depends upon each and every individual being primed for bodily self-control, self-regulation and an openness to surveillance by neighbors, family and any health organization. If smallpox

Deleuze (1997:129) emphasis added. 
or Ebola or West Nile virus or Jacob-Kreutzfeld syndrome takes on global proportions (which I suspect could very well happen) then it is probably only through a massively expanded regime of biopower (in conjunction with Sovereign and Normalizing Power) that any hope of containment of disease will lie. However, I still have serious reservations about the possibility that this regime of restraint will, in fact, amount to a just distribution of restraint and licence among all possible human bodies.

\section{Forms of Power and Intellectual Property: Analysis}

In this section, I will make an assessment of some aspects of the present intellectual property domain using some of the evaluative criteria from the Foucauldian microphysics that I just laid out. This assessment isn't exhaustive, but it demonstrates how one would apply critical ontology to a particular field. I will be looking primarily at copyright as it works in a university environment.

By now, we are quite a distance from an orthodox normative approach. My question, then, cannot be: Is Intellectual Property a good or a bad thing? My questions are: What are the cartographies of, forms of power-relations in which a particular form of intellectual property is functioning? How do these forms of power organize the spaces of freedom and obligation, of gains and losses? How do these arrangements qualify the kinds of freedoms or oppressions and also qualify different kinds of subjects who stand in many actual and potential relations to the discursive field of property?

Moreover, in keeping with my methodological qualifications of Chapter One, I have to also ask the questions "how it is that I myself am positioned vis-a-vis the realm of intellectual property" and how that positioning (and the subjectivity it offers me) is a part 
of my evaluative capacity regarding the question of intellectual property? I write this thesis and offer an assessment of copyright -- the privatization of property in ideas from the position of someone who can and does make claims of private ownership of ideas (that the content of the book of poetry called Ballast belongs to me, that this thesis is mine), and, as someone who must work with the terms of the same claims of others, past, present and future. My own functioning as a positive or negative subject of property, as an owner or as a thief, is very proximal to my understanding of myself and to the space of freedoms that I operate within, since I position myself as a professional almost entirely within the give and take of ideas. How I stand ethically or politically vis-a-vis this series is closely connected with my negotiating the formal features of the field(s) of power in which I, and these relations, are operating.

\section{Primitive Territorial Segment: Uncoded (Non-Property) Transmission}

The primitive territorial segment would correspond to a space where uncoded, or relatively uncoded materials, ideas, and persons are transmitted. In the university environment, it would be whatever is not considered conceptually or actually, to be a matter of property, private or otherwise. It is more accurate to say that this is not yet a space, a discursive field: it is that name give to the manifold random lines which skirt or cross the field of property without yet being incorporated into that zone as lines or zones of property, inheritance, citation, avowal, alienation, exclusion. Relatedly, the persons whose actions, creations or thoughts are the nodes from which lines emanate and join other nodes are neither marked from without as "owners", nor can they claim status of "ownership" or "rightful users" regarding anything which passes via them. The 
characteristics of these lines will determine a style of operation or actualization for individuals and groups who make up these lines. In the next section, I will investigate these lines more closely using conceptual terms from Deleuze and Guattari, the rhizome and the arborescent. The primitive territorial segment corresponds, qualitatively to rhizomes.

Using the Foucauldian schema, we recall this space as amorphous, undulating, irregular, and unstable. In the zone of the primitive territorial segment there is no established hierarchy according to which only certain kinds of persons may make use of these channels of transmission: reciprocity and fluidity prevails. Reciprocity rather than unilaterality is a characteristic of relations where the active capacity to make pass, to flow or to impinge upon is shared or at least circulates through all potential users randomly. As we saw in the section on potlatch, even though numayams are differentiated, organized as social groupings; that is, are not purely chaotic or formless, the relations between chief and commoner have elements of mutuality to them.

This kind of zone of connection can sustain being differentiated without ceasing to be a line, or ceasing to let things flow. What passes, what is taken or given, can adapt to non-isometric sections of transmission without breaking down or registering as a procedural error. This is because the line has a sequence but not a code. The number of users is never fully known or describable. There is a minimum level of relatedness among persons "engaged" in these lines of transmission which engenders a reasonably equitable level of self-directedness and activeness within these relations of power. Each has a 
roughly equal capacity "to know transformation"." The chief danger of this regime of power is that everyone is vulnerable to usurpation and there is no independent or external rule of law or code to which one can point for recourse.

A small number of lines or spaces within education persists (to varying degrees) as non-property intersubjective transmissions including: seminars, lectures, consultation with students and peers, hallways and stairwells. In the same way that the introduction of writing to Potlatch culture introduced the necessary condition for privatization of formerly public elements, in this case it seems that oral exchanges and physical movement remain outside channels of property. This microphysical feature suggests that if we have any commitment to the principles of the free transmission of ideas, and want to preserve the possibility of reciprocal roles of students and educators in coming to understanding, that the spaces of unrecorded conversation (without pamphlets, books, and electronic writing) must be preserved. However, this written/spoken distinction doesn't give us much space since as professors or laboratory technicians, our jobs are to produce ideas in a communicable form beyond just conversation. What you publish or invent while working as a lab technician or a professor is the property of the university. ${ }^{\mathrm{s0}}$ I will come back to this problem at the end.

Sovereign Power and Intellectual Property

Frederic Jameson, "Marxism and Dualism." A Deleuzian Century? Special Edition of The South Atlantic Ouarterly 96:3 (1997):413.

80 Discussion with Bernard Katz, Chief Librarian, University of Guelph. Summer 1999. 
The domain of private intellectual property rights are rapidly expanding the world over. Not only are more and more kinds of objects falling into the range of the equation: the-work-of-an-individual-which-makes-its-object-a-kind-of-property-for-that-privateindividual-under-a-system-of-established-laws-of-recognition, but sovereign power regimes the world over are scrambling to articulate in more and more detail the actual terms of copyright and patent law (and hence infraction) so that more and more cases can be brought under its capacity for judgment and control. It is a domain heavily coded by the Law, and increasingly so as a means to set the terms for judgment of right and wrong regarding the transmission and use of ideas. Fewer and fewer kinds of things cannot be owned, and fewer and fewer persons stand entirely independent of lines of ownership or theft of ideas, deliberate or accidental. This is to say that the domain of property is expanding; that the spaces previously outside this domain are falling more and more under its purview. Thinking, where property abuts it, is more and more contained. Lines of property are more rigid than lines of mere possession or transfer. That there are increasingly sophisticated lexicons for mapping a certain kind of investment to a certain limit called "ownership" suggest that the line which is private property itself is becoming overcoded. ${ }^{{ }^{1} 1}$ What this means is that amounts of productive thought can not only be matched to an adequate subjectivity (ownership), but can also be matched to an adequate amount of compensation, monetary or juridical. An accurate picture then, is the enlargement of the intellectual property regime as the regime of Sovereign power. Such a 81

Deleuze and Guattari (1987:212). 
pitch of activity belies the fact that at stake is either large amounts of money, large amounts of control, or large spaces of freedom which need/want carving out. Whether or not we as independently operating would-be-owners of ideas stand to gain little or much by our efforts to bring our own intellectual and artistic labors under this umbrella should be asked in light of the observation that this domain is able to award some and penalize others. As I described in the previous section, formal features of the domain of Sovereign power mean particular forms and amounts of freedoms, guided by a unique style, and distributed in a different manner than they were "before" the incursion of the rule of (property) law into the domain of ideas and their circulation.

Even though the Law is articulated and present, standing ready to say "No!" with stiff fines (and costs of reputation as an honest scholar or student), by and large, this formal arrangement organizes enormous, identifiable zones of non-cooperation. These zones are largely in favor of academics, the small-time players (but major tokens) in the domain. While we know that breaking copyright law is criminal activity, there are two important ways in which our positions as independent researchers empowers us to thwart the letter of the Law. My analysis suggests that this "thwarting" is not done in spite of the Law, but because of it.

First, consider the subject position of institutional affiliation. Learning and then teaching requires us to make use of others' ideas to a much greater extent than it requires us to produce our own to claim exclusivity to. The Universities that we work for and at, depend upon there being huge margins of ambivalence and toleration for adapting alienability clauses to their own purposes. A University is a subject of property which 
collects a handsome "tithe" off our modes of scholarship. These "tithes" are not just money, but an extract of affirmation which entrenches its fact of being, its central role in the domain of ideas. The University gains more than could ever be collected by a single individual whom a legal battle (or a copyright act collection procedure) procures a defence of infraction for. While the University spends large amounts of money on licensing, and indeed stands to lose large amounts in fines of infraction, it gets to exist because of the way this positions it on the side of the Law, while allying itself against the spirit of that same Law. The risk is unevenly distributed: it is doubtful that a University would cease to persist in its role after an infraction while it is doubtful than any one of us would. Additionally, the costs of mounting legal battles means that legal experts in copyright stand also to gain over the long run in the administration of the Law than any other particular party brought before the Law.

Second, there is a zone of freedom for us concerning the awkward fit between describing infractions and capacitating them. In the requirement that Laws are binding insofar as we are aware of them, above every photocopier there are indexes of legality (and thus illegality) carefully described. Each University that I've ever worked at runs a seminar at the beginning of term to walk faculty and graduate students through the how of copyright infraction. Faculty are provided with support staff hired expressly for these purposes, contact numbers, web sites devoted to clarification of terms, and standardized forms to fill out when making copy requests. Although this information is presented as self-protective ("how to ensure that your works are not pirated"), the vast asymmetry between what a faculty member produces and what s/he uses suggests that this 
information is more honestly directed to "how to ensure that you never pirate works". This models the vast asymmetry between the space which falls to the Law and the space which subjects can operate in quite beyond the reach of the Law in the formal array of Sovereign power. Being made aware of these means that we can flourish because these zones of illegality are simultaneously clarified, opened up, as zones of freedom from intervention. Not only do we capitalize on these, but we are encouraged to, again, in the general interests of supporting, rather than thwarting, "education".

For instance, whenever I have made Course Packs or placed material on reserve, there are always clear rules which I can easily manoever around (and others help me to do so): the Reserve Desk plays little compassion sovereign and "lets it go"; or they count the number of blank pages so that the photocopied material falls within the acceptable percentage of permitted copy; or I just adjust the font to change the amount of space I am "copying". If this is not possible, I order a book which has already made the necessary adjudications and decided on a price for this service and for use. The apparent expansion of procedure and limitation doesn't, in the end, alter the substantive questions of use of texts or how education proceeds. It alters the amount of negotiation, or the level of skills for detection and administration. An increase in techniques of articulation and detection requires subjects upon which those tools can be practiced. The presence of, for instance, "a copyright officer" in a University gives the impression of a crisis in intellectual honesty, and certainly something or someone is now in a position to detect and give witness to that crisis, hence to justify the incursion of the discourse of criminality into education. This is just like the fetal heart monitor. But, that is about technique or scale of 
surveillance, and not about the substantive issues of pedagogy and property. And, if you look hard at the whole scenario you see that ultimately none of these changes seem to affect the "amount" of space of others' ideas which I can access. Neither, I suspect, alter the ratios of original, rehashed and stolen ideas that make up the typical North American educational experience.

It is true that occasionally an unfortunate individual will make a gross blunder, and plagiarize a paper or show a film without obtaining a screening license. In these cases, we could say that they crossed the dividing line and entered too close to the King not to be noticed. This means that he will then have to pay for the transgression. (He will hear some kind of No! and have to answer to it by paying a fine of some kind). But he too will have the ambiguities of representational fidelity available to him in his defense. Anyone who has tried to prove plagiarism knows the extensive difficulties involved in proving an infraction. And the details of these cases only help the rest of us (University legal advisors and we the users) reposition ourselves so that we don't trip the wire. For example, I was alerted to one of my student's having plagiarized a paper by virtue of a consistent spelling mistake she had made on three out of four assignments. She knows now to use a spell checker on all her work. She isn't any less likely to plagiarize a paper. She's actually in a better position to do so because she knows now exactly how to remove the things that trip the wire.

In all of this, there is a classic Foucauldian inversion at work: while, on the one hand, there appears to be an expansive endorsement of the value of policing intellectual property trespass, "underneath" there is an equally large gain in permissiveness and 
access to these contraband goods.

Now, these disclosures do not privilege any single individual, as long as they are distributed evenly. These "resources" should be as available to students as they are to faculty. These procedural requirements should be widely posted, and thus spread this possible "gain" over the widest possible area. The "freedoms" available are thus a function of whether the Law is reported, knowable, legible, understandable. Where disclosures are encased in legalese, or made available only to a few, those few inevitably capitalize on that information to advance themselves or to anchor well within a pocket of undetectable illegality. As we saw, this is unfortunately the case with patent disclosure. A just society isn't only a question of the faimess of its laws, but the distribution of access. The key function is circulation. Property laws which create a two-tier system of those who stand to gain by its operation and those who know that they stand to gain by its operation will offer advantage and self-directedness to some and not to others.

By virtue of the fairly large vacuoles of illegality that are available to me as a particularly positioned owner and/or user of intellectual property, it is in my interests to recommend that this regime be maintained and even expanded. As an actual would-be "owner" of ideas, this regime provides some wide but nonetheless firm standards which clearly identify me as an owner and therefore privy to particular goods or gains. Unlike the "outlaw" risks of the primitive territorial lines, there is recourse under this regime, to reparation. Another positive example of the Sovereign regime working to sustain a certain "fair" distribution of possibilities involves non-profit patenting. In the U.S., a large trust philanthropy established a foundation which maps genes, and patents all the 
gene probes found, but will not enforce the patents for commercial gain. In this scheme, one goal - effective gathering and storage of information, and its transfer for educational purposes, a public database (GenBank) - is enabled by Sovereign structures. Again, however, the deeper structural part that determines whether this in fact will translate into gains and losses being distributed in one fashion rather than another, is circulation and access: in this instance: whether or not one has access to the Internet.

Moreover, by virtue of the formal distribution of relations between myself and others, if and when I am identified as, or take up the identity of owner of intellectual property, this does not have an effect of everyone else. Everyone is not automatically affected ("retagged") by virtue of their proximity to, or distance from me. In this regime, an individual is not a norm. I am an instance. The concentrated rules are the norms. Relations are binary, between these rules and the instances, but not circular, involving all. What is important about this is that their own proximity to or distance from the Law itself can be affected by my taking up the identity of the subject of property (negative or positive), but their proximity to subjectivities is not affected. Subject identities only become affected by their own relationship to the Law. In this sense, the Sovereign regime is not conducive of violence.

I have some reservations about the supporting the affirmation of this regime of power in the domain of property. These have to do with the kinds of ontological commitments about property and ownership which are built into the cartography of a Sovereign regime, whether these can be sustained across new forms of property, and what this conceptual inadequacy might mean for the capacity of the Rule of Law to support a 
just and non-violent society.

The privatization of property has moved from private ownership in one's body, to land, to slaves and animals and things, to ideas as they are made manifest in an item, to ideas as they are reproduced by a body making use of them to do something else. The rule of Law must be able to articulate more and more complex accounts of the difference between propriety and impropriety. The regime functions in its capacity to match claims to the things which are being claimed, to map infractions to evidence of infraction, to connect work to land, to demonstrate independent effort in creative products, to line up families and entitlements, etc.

Ownership depends upon the capacity to include or exclude. The direction that private property is moving means that the concept of "ownership" to include or to exclude not just clearly identified wholes -- plots of land with fences marking them off, human bodies, the celestial realm, an ocean, a physical book and its certain number of copies -- but increasingly, parts of wholes. Another way to express this is to envision the cartography of property law to lie in two parallel and similarly scaled lines: the line that is the ownership of something itself and the line that checks that ownership against some other segment (work, history, inheritance, identity, locality) in order to judge the merit of the claim. The newer forms of property and ownership mean that those two lines are becoming inversely related: the scales are off, not just spatially but conceptually. The thing owned is too large relative to the work done to claim it; or the thing owned is too small relative to the capacity of some other thing to detect it and it alone; or, the thing owning has existed for a short number of years while the thing now owned has existed for 
millions of years.... These changes of scale threaten to place the One judging/affirming, the Eye of power, to the outside, too far away or too off in scale to be used to make a definitive case for exclusion or inclusion. It may turn out that Sovereign power will prove less and less functionally or conceptually able to make a case for either alienability or inalienability; that is, to control the domain of property.

“Expressed Sequence Tags" (EST's) are a possible example of a region of this complication. Presently, it is possible to file a patent on a length of gene, a gene fragment:

The 300- to 500-base gene fragments...represent only $10 \%$ to $30 \%$ of the average cDNA. A cDNA molecule is a laboratory-made version of a gene that contains only its information-rich (exon) regions; these molecules provide a way for genome researchers to fast-forward through the genome to biologically important areas. ${ }^{82}$

This gene fragment bears a "representational" relation to a whole, which is an entire gene (say BRCII, the alleged "breast cancer gene"). Patents are filed for and issued on these smaller gene segments for their use as potential diagnostic radioactive tags for the presence of the full gene. Usage will likely involve early pregnancy genetic testing of the fetus. But the patent is not issued for the process which the gene will be used in, but for the actual section of code that the research has isolated. This seems like a good thing. One person or organization, as owners of this disease gene fragment patent, stands to make a lot of money in preventative health care expenditures while another group, users, stand to make earlier better informed health-care decisions. A third possible group would be those

82

“Patenting Gene Fragments, SNPS, Proteins, Genes and Gene Tests.", $<$ hittp://www.ornl.gov./hgmis/elsi/patents.html $\gg$ (2001):7. 
who are licensed to administer the tests and collect the royalties for the owner.

However, there is something novel about this particular relation of ownership and use, in relation to many different overlaps of parts and wholes.

For one thing, many people already "have" that particular gene fragment as part of their own bodies, their genetic makeup. A potentially infinite number of persons and organic beings. If someone, Dr. X, "owns" that gene fragment, then how would we describe the relationship between the person whose body "contains" that actual sequence of DNA and the object which is the object of Dr.X's ownership claim? Are they carriers but not owners? If the claim of ownership that Dr. X can make is a claim which inheres and gains its legal and ethical force by virtue of its work -- that Dr. X is the owner because of the investment in time and money that he has made in it, and the legal proceedings which he has procedurally respected in order to mark and claim ownership -then those of us who have some kind of a physical relationship to that same gene fragment, but have "done" nothing with it, nor plan to put that part to work for "the greater good", are in no way owners of that particular fragment. What would we be? Are we carriers, users, or (accidental) trespassers. "Carrier" has never been a status of high esteem in any tradition. "User" does not adequately describe the relationship that we have with parts of our bodies. "Owner" does not promise to Dr. X. a system for exclusion and/or renumeration, at least as far as a gene fragment is concerned, except perhaps when that gene is isolated. I don't have the tools to explain or understand the conceptual shifts that these new forms of property seem to require.

As more and more (three million applications and rising...) and smaller and 
smaller gene sequences are patented, inversely more and more persons are placed in the subject position of "having-relations-to- things-already-owned". Presumably this could include persons who previously held patents for larger genes sequences. "Those who use sequences from public databases today risk facing a future injunction if those sequences turn out to be patented by a private company on the basis of previously filed patent applications." ${ }^{\text {83 }}$ Presumably the former group would consists largely of scientific researchers. The premise that science will advance more rapidly if researchers enjoy free access to knowledge is compromised by the way that ownership of parts prevents free access to the whole sequence. Also, there are costs associated with the work of determining whether and which patents are already held on areas being studied, costs shunted from the lab to the administrative sectors of scientific ventures, the very same "copyright officers" mentioned earlier.

Patenting of the procedures for gene fragment isolation and application is an entirely different matter. The rights associated with developing genetic procedures would be use rights rather than private property rights. Endorsing the expansion of the domain of private property rights to include smaller and smaller parts of the building blocks of life, invites the unravelling of the basic logic of owner and owned, and may eventually usher in the conversion of ownership rights to use rights. Use rights are more likely to operate through a Normalizing regime of power.

What I want to suggest at this point is that a Sovereign regime of power offers a

(ibid:5). Clearly, this parts:whole relation threatens to compromise or limit the benefits of the GenBank, or again, to re-route them through administrative codes rather than remain a direct access relation. 
reasonably fair distribution of freedoms and obligations. But whether or not this regime will be adequate to newer forms of property will depend upon the "fit" between the material changes in kinds of property and the conceptual and administrative frameworks which support those.

\section{The Normalizing Regime and Copyright}

Private property, whether in land or in ideas, also involves a Normalizing in addition to a Sovereign regime of power. This fact can be detected in its terms and modes of fine control. Given the arbitrary and fairly large "vacuoles of non-detection" which a field of Sovereign power exhibits, and given the fact that it seems as though the level of non-compliance is quite minimal, this suggests that something else besides the threat of contravention of Law is at work in the domain of intellectual property to introduce measures of restraint.

Consider that you don't, and why you don't, turn your fellow Nabster or "unlicenced public performance" (non-compliance) peers in. Nor will your peers turn you in. Insofar as it is actually a group of peers, it is not in anyone's interests to do so. In having killed the King, modern man managed to carve out a space of operation independent of him. It is in their interests to confirm positions of mutual guilt, to participate in its spoils, and also to police the reoccupation of the Sovereign center by any of the local would-be Kings. Turning a peer in invokes the attention of the Law to the fraternal circle, and hence shifts the regime from a circle back into a binary. A binary is underfoot and thus it threatens to inspect you too; to mark you as a thief. If the authorities come to your door, or check your files, they're sure to find something incriminating. 
This entire sub-system, or secondary zone of power works through the formal features of positionality on a circle. This is the key formal feature of a Normalizing regime. Since everyone knows that everyone else who "occupies the same position" (whether you know that person or not is irrelevant: the abstract principles of justice, and the abstract individual replace the case by case singularity of the Sovereign regime) is taking roughly the same kinds of liberties and making roughly the same kinds of obediences, staying in a circle assures one the best possible chance of protection: whether you are marked or "outed" as a trespasser or a pirate seems more a matter of bad luck (randomly circulating among the subjects) than anything additional you might have done which would mark you as a uniquely worthy subject of judgment. There is an odd freedom, then, in circulating the risks of moral luck. Right and Wrong here are not simply a question of knowing the Law and obeying it, but, additionally, of knowing the expectations of ones' peer group and being loyal to that.

This is not about theft per se but about being true to the spirit of the covenant. The spirit of the covenant is not absolute, but works by degrees. It works according to norms rather than absolutes. The norm is built up and animated by two components: by personnages and by competencies.

First, although the general story is of the single eye of Sovereign Power emptied and replaced by the empty center which is The Social Contract, for every particular discursive field, that empty eye is occupied by no one in particular, but by an ideal abstract personnage who embodies some ideal truth about the membership. In the case of copyright as we already saw in Chapter Four, those figures are "the Author", "the 
Thinker" or "the Inventor". The Author is the figure invested with a standard of intelligibility according to which each and every person might recognize themselves, and thus see themselves as privy to the domain. Recall that property in ideas has to be grounded in a concrete locus or a lineage such that there is someone who can be said to be the rightful inheritor or owner of an idea. Recall that a certain amount of policing of the field of intellectual property occurs through the notion of the respect due to that "author": we should refrain from changing a work, or taking it up as and presenting it as our own, not only because of the price we might pay for getting caught, but because to do so disrespects the idealized fact of authorship. The fact of authorship is not disrespected by its illegal application. This fact is respected in attending to the proper procedures for acknowledgment. Here, the uptake or imposition of these subjects of property does, in fact, retag the general field as persons identify with, or are disidentified with, these ideals. Nodes of judgments are spread more continuously across this field of relations.

Acknowledgment is about competency, not fact. It is in this sense about normalization rather than rule. One is not actually asking permission of anyone; rather, one is demonstrating one's capacity to do that asking. One is said to be more or less in a position of infraction, depending entirely upon the degree to which one respects the terms of reproduction and acknowledgment. This constraint is tied to "fidelity" to the ideal of the author. "Acceptable use", "abuse" and "misuse" are distributed by degree of conformity to procedure, rather than related to the bare fact of reproduction of material. This is why I claim that this is a Normalizing regime. While the letter of the Law guides us around rules to a zone of neutrality, or nails us with a clear infraction, the spirit of the 
Law guides us through a series of procedural requirements to remain within the zone of honor. Honor consists in following procedural requirements and making the proper signals toward the fact of another's prior authorship.

It is a matter of the right degree: Size of margins, kinds of ink that signatures are signed in, dates of submission of patent application, acceptable stock of videocassette or paper, properly or improperly filled forms, records of having made a phone telling someone at some office the details of a non-licenced video screening, putting a copyright symbol on a work, having all the citations in the right style.

The illegality or immorality of a production, therefore the ground of a claim or ownership or a claim of trespass, depends more and more upon the speed and skill of the performance of these competencies than the content of them. It is infinitely easier to prove an error in procedure than a substantive infraction. Rights of ownership or access go to the competent while loss of rights of use or ownership incur for those who fail to work with the terms of procedure. If competency and not some deeper substantive claim is a basis for some zone of ownership or user claims, then those who have the know-how and the means to develop and use the particular competencies which are demanded as proof of compliance, have a tremendous advantage over those who have not got those same means or skills. At this point in time, it is clear that being included in or being excluded from the domain of intellectual property is tied up with access to technology. Speed is the determining factor in deciding between thousands of perfectly competent users. Clearance rights, or ownership rights will go to those who can actually tap into and properly mark information; that is, the best wired. Everyone else will simply not be in a 
position on the circle, nor will they be recognized as related to the abstract normalizing subject. Expanding private property in ideas from the positions which are equipped to determine the procedures, and thus to follow them - positions that intellectuals are in -almost guarantees the further stratification of society into an access upper-class and a trespass under-class. This seems to be especially true when we factor in the globalization of I.P.R.'s.

That private property in ideas is a Normalizing regime is to suggest that the competencies which are demanded as adequate proof for access or use are not substantively linked to the actual property but are themselves merely the kinds of proofs demanded by persons who are in a position to demonstrate these within a reasonable range. On the other hand, the history of private property is a story of work as the legitimate basis of ownership, and all "work" can be said to be that which serves as adequate demonstrations of ownership. Fairness does not require that competency regimes be removed but that they be expanded such that the widest possible range of people's identities and skills fall within the margin of the "normal" and "legitimate". Biopower and Property

Biopower is the regime of power where normalizing judgments have been concentrated in the individual and whose subject is biological function. Stylistically, continuous assessment is relayed from one part of the Self to another part of the Self regarding one's accordance with, or one's deviation from, a set of internalized norms regarding organic deviance or normalcy. Moreover, as I indicated, one is also selfmonitoring the level of one's adherence to program of monitoring and adjustment. 
Generally speaking, regarding property, biopower would involve self-control of the body not in order, necessarily, to abide by an external set of constraints (someone else's property, someone else's space), but in order to cultivate a continuous means of affirming one's relationship to self as a relationship of ownership. Presumably this relationship requires containment, but in this containment, would register as affirmative to the individual independent of the kinds of civic affirmation garnered under a Normalizing regime. One area which presently does not fall squarely within the discursive limits of property is that of biological offspring. As more prenatal screening and therapies become available to "improve" the biology (not just the disease-status) of the child-to-be, many more aspects of reproduction besides the natalist series will be subject to biopower adjustments, and, as a result, invoke property relations into not just one future generation, but potentially, an infinite series.

Presently, I don't describe my relationship to myself, bodily or otherwise, as a "relationship of ownership". Neither do I describe my relationship to my ideas thus, and cultivate the will and the means to competently demarcate and police those as mine. As I tried to show in Chapter Three, whenever I am disposed to make privacy claims about my body or my ideas, these seem to be a function of the context rather than a function of some objective truth about personhood.

However, as more and more parts of the wholes come to be placed under the rubric of relations of property, including peoples' relationships to their bodies and body parts (theirs and others') it is not unlikely that among the relationships that I presently conceive of having "among" the parts of myself, a relationship of ownership may enter 
my conception of self. Politically, it might turn out to be expedient to be prepared to make such reconceptualizations. Furthermore, if it is by a system of bodily competencies which rights of ownership or holding are established, then this will demand of me a participation in that system of bodily monitoring. Foucault and others have argued that, under certain sociopolitical conditions, this demand becomes a demand that the self administers as a means of receiving affirmation and self-respect. It is all too easy to imagine that continuous private investments in ideal deposition, in monitoring and in demonstrating competencies in self-ownership would take me quite far away from my investments in any other forms of relations. It seems to me that it would turn me into a kind of microfascist microbureaucrat rather than someone who had any of the freedoms I described earlier, especially the freedom to opt-out of discursive "play".

\section{Tentative Conclusion from Foucauldian Cartographic Analysis}

In this section, I tried to tie the capacity for judgment or freedom to formal features of relations of power found in Foucault. Four different regimes of power articulate four different cartographies of the subject-in-relation. From these different cartographies one can make an assessment of the amounts, kinds, spaces and styles of restraint that will impinge upon subjects in any domain where those forms of power are operating. In plain terms, I wanted to be able to say whether and how it might be better or worse that the domain of intellectual property be retracted, expanded as a legal framework, expanded as a normative (moral or sociopolitical) framework, or brought more and more into the biological realm. By many accounts, expanding the domain of intellectual property is harmonious with expanding individual autonomy. 
Aspects of each of these regimes of power seem to be present to the domain of property. It is not likely that one will ever be entirely present or absent, but using these principles we can speak about whether one form ought to dominate. Tentatively, it seems as though a Sovereign regime offers the best mix of equality of opportunity, reciprocity, clarity of positioning. It also tolerates the greatest range of creativity without the level of risk that a Prediscursive Segment carries. These conditions figure strongly in my account of the necessary conditions for freedom. A limitation to this analysis, though, seems to be that, although we have produced a very accurate catalogue of regimes of power and matched these to the scaffolding of different kinds of property, and, have some evaluative principles for adjudicating between these forms, we have not been told by Foucauldian cartography how one might move from type to type. In the next section, we will examine two Deleuzian cartographic principles which spell out more clearly the links between form, desires and resistance. Then we will see how this tells us what to do about property relations.

\section{Deleuze as Critical Cartographer: Rhizome and Arborescent Lines}

Deleuze was also a critical cartographer. A discussion with Clare Parnet called

"Politics" begins with this claim:

As individuals and groups we are made of lines, lines that are very diverse in nature. The first type of line (there are many of this type) that forms us is segmentary, or rigidly segmented: family/profession; work/vacation; family/then school/then army/then factory/then retirement. Each time, from one segment to another we are told, 'Now you are no longer a child'; then at school, 'Now you are no longer at home'...all kinds of well-defined 
segments, going in every sense, these bundles of segmented lines.... ${ }^{8-4}$

Deleuze distinguished between three distinct kinds of lines: rigid segments, also known as arborescent lines; supple segments, also knows as rhizomes, and what he called lines of flight. In this section, I will describe the abstract features of the first two, and tie those features in to Deleuze's evaluative criteria. In the following section, I will tie those to evaluative criteria in light of the questions of property in ideas.

\section{Arborescent Lines}

This is the most common kind of lineal segment. Its name comes from the figure of the tree. A tree is a sequence of lines, all which refer back to an originary trunk, or root, or center. These lines can be divided into segments, striations, generations, branches ("deep structures" or "grammars"), but none of these divisions can do anything on its own. This is another way of saying that they refer, either backwards to an origin, or defer, forward or sideways, to an authority or a telos. These lines may point to an outside but have no direct and immediate contact with it. Also, one cannot move parts around and still preserve the overall function: the lines are rigid in their placement relative to one another and to the root or end. New segments arise from binary functions which reproduce the mother segment and therefore retain a base dichotomy of original and copy; or central and marginal. Deleuze claims that the dominant operator is a disjunctive synthesis, the "not": A Man Not a Woman; A Child Not an Adult. This ensures two structural characteristics of arborescent lines: hierarchy and overcoded segments. 
Judgment is possible since "each time a binary operates...it will produce a [clear] choice between the elements...". ${ }^{\mathrm{ss}}$ Moreover, its corollary, policing and the settling of dues is possible since all rigid segments can be superimposed, compared, replaced by another of equal rigidity (an execution for a bombing, a quarter for a tooth, a licence for an invention).

Each new segment is a point in an overall positioning; the overall itself is mappable, legible, memorable. We call these forever added-to lines: 'histories, 'family trees', 'personality' or 'careers'. 'Property' is also one of these, an added-to history of names-bodies-land-items. In A Thousand Plateaus Deleuze identifies private property as an arborescent line:

Private property implies a space that has been overcoded and gridded by surveying. Not only does each line have its segments, but the segments of one line correspond to those of another; for example, the wage regime establishes a correspondence between monetary segments, production segments, and consumable-goods segments. ${ }^{86}$

Later on, in "The Treatise on Nomadology" he identifies all forms of property as striations. ${ }^{87}$ In Anti-Oedipus, he distinguishes the Barbaric from the Capitalist regime according to their modes of transfer of names and things. In a Barbaric regime the points of transfer are not the primary players: the unfolding line of transfer itself is. $^{\text {sz }} \mathrm{A}$

(ibid:77).

86

Deleuze and Guattari (1987:212).

87

(ibid:388).

88

On the primacy of the thing transferred over the persons doing the transfer, see Mauss'(1990: 11-12) description of the hau of Polyenisian polynesian cultures. 
mechanism of alliance means lateral transfers predominate. A capitalist regime features more "calcified lines of transfer"where the points of transfer come before, or come to dominate the line which connects them: First there are persons, with positions or names, and the things they have; second are the branching transfers which begin and end with these. ${ }^{89}$ This cartographic realignment was well illustrated in the shifts of filiation and transfer before and after potlatching cultures encountered market economy cultures. Prior to European encounter, status was conferred upon individuals, temporarily, by a complex system of transfer and circulation of status, or power, as it too was temporarily inscribed in names, things, dances, foods.

Names are eternal and...although the holders of a name may live and die, the name goes on forever. This was true not only of names bestowed on people but also of names given to places, villages, houses, canoes, boxes, or feast dishes, whose names would go on even if the objects disintegrated and needed to be replaced. ${ }^{90}$

Though lines were certainly made, they were not arborescent or coded. The lines were made with persons and things as they came into relations and positions, temporally and socioculturally: the persons or things did not make and regulate the lines according to some independent, pre-existing standard of measure.

However, after contact with the Europeans, and the cross-over of market-economy into potlatch-economy we saw that arborescent, coded lines formed and eventually dominated. This was because of the introduction of two standards of measure: the

Wolf (1999:89). 
individual (which came to apply to all persons and to the chief), and money (which came to apply to everything).

Throughout the second part of the nineteenth century, the solidary relationship of chiefs to their tribes and numayams increasingly yielded to "individualized" coalitions...and self-oriented promotion of individual personnages, family lines, and followerships while loosening the collective bonds.... The cosmological understandings of chiefship were reconfigured into a political ideology that emphasized the role of chiefs as "standing at the head", "the one alone at the front"...."

Using cartographic analysis we can see that these changes involved the articulation of a certain kind of line: the arborescent.

\section{Rhizomes}

An entirely different kind of line Deleuze describes as "the rhizome". Rhizome is both a practical kind or style of thing, and a concept, a way of thinking about something, an image of thought for seeing how things connect up with a different logic than arborescence. A rhizome is more supple than rigid, more smooth than striated. A rhizome operates via three distinct principles of formation. First, the principles of connect and heterogeneity. What distinguishes a rhizome from an arborescent line is that the points and order, and thus possibilities of transfer and connectivity, both location and direction, are not predetermined. In principle, any one point can come into relation with any other point without destroying a base code or functional effectiveness. Points do not necessarily refer to any deeper, truer or prior point. A rhizome is centerless: it does not align origins or authenticity. Different parts of different series can make non-dialectical connections 
with others; in fact, its mode is "to never cease to connect". Links are not excluded, $a$ priori. (Nor are any included, a priori). Its operational mode is not disjunction but convergence and conjunction. It says "AND/OR" or simply "AND", as in Adult AND/OR Child, or Mother AND Father. But this is not a whatever:"2: Its spirit is decidedly determined-to-be-indeterminate.

The system of marriages among potlatching cultures was serial in this precise manner, and distressing to the government census-takers and the missionaries for its seriality. ${ }^{93}$ With the initial betrothal (between "roughly comparables") came the setting of the bride-price, an amount of status or wealth paid to the bride's family by the groom's. After the actual transfer of the bride-price to the family of the bride did she move to her groom's house. "In doing so, however, she did not relinquish her membership in her natal numayam." ${ }^{94}$ Finally, in the spirit of potlatch, this payment would be "repayed" to the family of the groom, usually after the birth of the first child. It included not only material wealth multiplied many times over, but "intangibles" like names from the maternal numayam and rights to imitation, which were held in trust for the children, both female and male, of this betrothal. One aspects of this sequence which illustrates heterogeneity is that the children are not automatically assigned to a lineage, but will acquire a seat in a multiplicity of possible groups, depending on further relations. A second aspect which

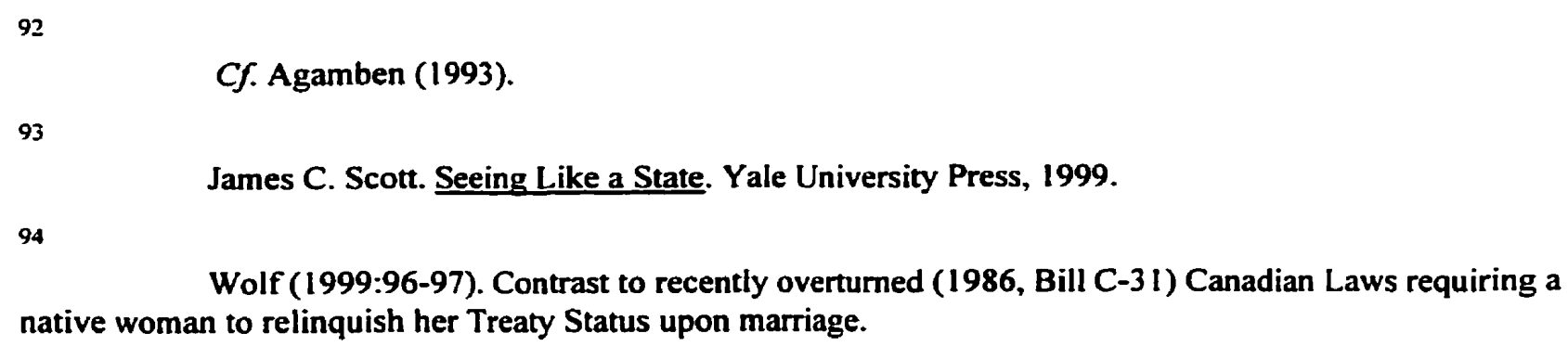
native woman to relinquish her Treaty Status upon marriage. 
illustrates connectivity is that the repayment of the marriage debt effectively repurchased the woman to her family; that is, her marriage was terminated. Yet, she is "given" her name back, in addition to the wealth that was secured by the initial transactions. This fluid seriality in effect increases a woman's wealth and status through sequential marriages. Looking at marriage possibilities as cartographic variants gives a very different explanation for the disenfranchisement of women, ${ }^{95}$ especially in conjunction with subsequent childbearing.

The third principle of rhizome formation is the principle of asignifying rupture.

What this means is that segments can cease to be in conjunction with other parts (immigrants from their homelands, one tribe from its numayam, babies from their biological mommies) without this disjunction grounding a deeper point, a touchstone for narrative or scarring which, in fact, rejoins the split parts, resignifying a bivalent unity. The rhizome's asignification is both its form and its logic, a logic of "multiplicity, difference and singularity". This multiplicity, however, should not "be confused with traditional notions of 'the many' or 'manifold' or 'variety'.96 Difference is not to be confused with distinction, opposition or contradiction; indeed difference is that which is freed from the logic of such notions. "Two things may be said to 'differ freely' when, falling in no class, they fall together in a kind of indefinite neighboring." This neighboring is cartographically indefinite but affectively intense, "proximally

John Stuart Mill and Harriet Taylor Mill, "Married Women's Property." Sexual Equality. Ed. Ann Robertson and John Robson.. University of Toronto Press, 1994:38-41.

96 John Rajchman. The Deleuze Connections. Cambridge: The M.I.T. Press, 2000:54. 
emphatic". ${ }^{97}$ Finally,

...singularity is not an instance or an instantiation of anything. It is not particularity nor uniqueness...yet not a logical deficiency or an incoherence but rather...a firstness, a kind of power or chance, a freshness of what has not yet been made definite by habit or law. ${ }^{98}$

A rhizome then, has or is a lineal logic of a peculiar sort, distinct from the peculiar logic of arborescence. An uncoded diagram replaces a schematism. A nomad replaces a bureaucrat. Becoming usurps being. An event replaces a historical moment. ${ }^{99}$ What replaces property? Should property be replaced? To answer this, we turn to Deleuze's critical evaluation of rhizomatic and arborescent lines.

\section{Deleuze's EthicoOntological Evaluation: Rhizome and Becoming}

To give a fully adequate account of the desirability of the rhizome over the arborescent would require me to squeeze all of Deleuze's thought into this short section. I can't do that. I'll just very briefly give an account of Deleuze's evaluative tone.

Deleuze was passionate about the beauty and necessity of becoming. As lines, we are implicated in series of transfers and connections, yet, we have some manoeuverability as to whether we embody and extend the features of rhizomatic lines or arborescent lines. The possibilities of becoming are directly mediated by the formal and dynamic features of these series. Deleuze thought that the rhizomatic line, (and the nomad character who lives that line) has an openness and a deep multiplicity to it which enables becoming.

Rosi Braidotti. Nomadic Subjects. New York: Columbia, 1994:5;113-1 14.

Rajchman (2000:55).

99

Cf. Foucault, "Nietzsche, Genealogy, History."(1984c:139-164). 
Conversely, the arborescent line (and the sedentary character who occupies it) has a closed single-mindedness to it which favors being. Rigid lines do not vibrate or resonate. Cartography is responsible for these differences. With a rhizome there is an increased number and kinds of unlikely encounters, unsuspecting alliances, unscheduled experiences which give rise both to creativeness and complex wisdom. The style or the logic of rhizomatic conjunction "frees affective force" 100 - that is, passion and intensity whereever it is circumscribed by habits of thinking, of moving the body, of association. When nothing vibrates there is no heat or life.

It is not about doing away with thinking, or gestures, or historicity. Rhizomes carry a high enough valence to change our sensibilities, and thus our capacities to respond in the present, (without deferral or referral) to the becoming in being: in thinking, in gestures, in political action, in literature, in historical events, in sex. Here is what Deleuze sees in approaching "history" from and as a rhizome, compared to, yet in relation to, history's arborescence:

[T]here are two ways of considering events, one being to follow the course of the event, gather how it comes about historically, how it's prepared and then decomposes in history [arborescence, memory], while the other way is to go back into the event [into its sense] to take one's place in it as a becoming, to grow both old and young in it at once. What history grasps in an event is the way it's actualized in particular circumstances; the event's becoming is beyond the scope of history. History isn't experimental, it's just the set of more of less preconditions that make it possible to experiment with something beyond history. But without history the experimentation would remain indeterminate, lacking any initial 
conditions.... ${ }^{101}$

In this sketch, Deleuze offers us a diagram of intellectual property and how to approach it as a matter of our own insertion into lines of one kind of desire or another.

\section{Intellectual Property Schemes as Lines}

There are many different kinds of intellectual property including copyright, patent, and industrial trademark. Cartographically, intellectual property of any kind is the drawing of an arborescent line between two or more things: a whiz-kid and an invention, an author, her manuscripts and her reputation, a company and its Research\&Development money. This line can be public, metaphoric or symbolic. It organizes the kind of history a story of blood, of luck, of toil - which excludes others. Others, ones coming after the first, or out of character with the rest, cannot incorporate its parts into another arrangement. One can make use of an already-aligned thing, or claim filiation with an original source, but legally and ethically, one must seek permission, offer acknowledgment, perform certain rituals (such as making a disclaimer or putting a c symbol on the first sheaf of paper), pay a tithe, show identification, and most importantly, demonstrate care regarding the fidelity and integrity of reproduction of the line. Let me give you one example: films are intellectual property. Their use falls under the laws of "public performance". If you go to a movie theater, part of your ticket goes to the owner so that your eyes can enjoy their private property in public. If you rent a video, part of the rental money finds its way back to that same owner. The amounts that you pay are 
determined by a calculus which aligns a quotient of the cost to a fraction of the viewers. These fractions slide when showing become more and more "privatized". The owners don't get the right "recompense" if the renters all crowd into one livingroom and watch the same rental. Public performance restrictions are intellectual property laws which attempt to enforce alignments using money, blood, and intention. If you screen a video in a public space you must apply for a public performance license or else you are in contravention of those laws. ${ }^{102}$ If you screen a movie in a bar, you pay for a licence for each screening based on room capacity. If you screen a movie for "educational purposes you still have to get a license but it costs nothing. It consists of making a phone call to a bureau which keeps a record of your dutifulness. But you also have to tell them how many persons will be in the room, how many monitors the film is running on, and (my favorite detail) whether the viewers are related by blood. ${ }^{103}$

Meeting conditions such as these never converts usership into ownership. Users are never free to take on an owned thing, unmediated. Only trunk of the tree is ownership: all other branches are derivative. Proprietary relations in all their instantiations consists in making or joining an arborescent line.

The dominant argument in support private property, whether in things or ideas, which can be found from Locke through to Nozick and now Capitol Records is that such securing measures are necessary for creativity. In other words, that unless a rigid

Bettig (1996:12-35). 
arborescence were guaranteed, the creative impulse would simply not flow. This assumes that there is a lack or a sterility in general, and that it is caused by a structural repression.

Deleuze's structural concepts give us a means to dispute that assumption. And here, there is a resonance between the structural "alternatives" Deleuze sketches and Foucault's criticisms of our perceptions about creative thinking and its requirements.

I don't subscribe to the notion of a decadence, of a lack of writers, of the sterility of thought...on the contrary, I believe that there is a plethora. What we are suffering from is not a void, but an inadequate means for thinking about everything that is happening....what is our problem? Too little: channels of communication that are too narrow, almost monopolistic. We mustn't adopt a protectionist attitude to stop "bad" information from invading and stifling the "good". We must rather increase the possibility for movement backwards and forwards. This would not lead, as people fear, to uniformity and levelling down, but on the contrary, to the simultaneous existence and differentiation of these various networks. ${ }^{104}$

Deleuze's notion of rhizome helps to explicate what those alternate "channels" would be like, and how these are radically different from standard assumptions about innovation.

First, innovation per se is a passion, a rhizomatic force of desire which does not run toward or from any clear location, nor along any predetermined route. People think and write and make and hum along a different series of impulses than the one which cannibalizes those into habits of craft, theory, economics or authorship. Speaking from personal experience, trying to write a book of poetry with a contract hanging over your head and all the titles laid out on blank pages is a strategy for inviting dullness and pretense into one's writing, if one can even get writing. Interviews and Other Writings: 1977-1984. Ed. Lawrence D. Kritzman. New York: Routledge, 1988:327-8. 
Yet, it is not that arborescence is strictly inimical to rhizomatics. To declare that would be falling prey to a didactic romanticism. As we have seen from the example of history: the non-vibrating segment has an important part to play in organizing impulses so that they can have a place to leap from. What we can steal from Deleuze is a kind of clarity about the proper mix of relations of these lines to one another, and of these lines to creative possibility. The point is to steady something enough to create. If I claim a relation to Ballast it is largely in this spirit. But extensive loyalty, nostalgia and deferral can produce a flattening of affect, flat imitation. ${ }^{105}$ This flattening however, unlike the flattening that is potlatch, does not have the structures of recycling to help it to become something vital again. The rhizome always comes first and, as it moves, it must retain its distinct style of line. In matters of creativity, the arborescent should never dominate. The Specific Intellectual, the Philosopher: Arborescent Theory and Practices.

In this section I want to focus on some of the practices which we regularly enact in our roles as paid or sanctioned intellectuals. Specifically, I want to focus on the structural features that certain practices in the discipline of philosophy maintain or extend, so as to highlight how those practices in fact extend rather than disrupt the arborescent lines of property. There are several areas one could focus on: our relations to texts; our relations to our own authorship; our relations to law (of which intellectual property laws are of foremost interest); our relations to Truth; our relations to our

Judith Butler (1990:33-34;124-141). Masquerade and parody are not ends in themselves: they are conscious strategies which aim to shake off the suffocating flatness of habitual representation. In the context of the potlatch, the winter ceremonies are masquerade-parties of sorts where the right to parody (contained in a particular dance) is passed, via marriage or succession, in order to "invoke and re-create the initialconditons of the Kwakiutl world." (Smith (1999:89)). 
students; our relations to our offices and secretaries; our relations to the communities in which we work. I would like to make some brief and unpleasant observations about a few of these, but would be happy to elaborate on others during the discussion period.

\section{Our relations to Truth}

Much ink has already been spilled regarding the quintessential Oedipal nature of academic thinking; of theory in particular. ${ }^{106}$ I don't think it would be an overgeneralization to say that one of the central projects of feminist theory (and not only feminist theory) has been to "out" the tendency for philosophizing to be a branching treelike domain which operates "toward Truth" and "toward the Good" only by deep mechanisms of disjunctive synthesis which systematically eject alternate candidates and styles of these, mechanisms which are, ironically, epistemically and morally suspect. The dominant logic in the history of philosophy as a discipline uses but expels or colonizes rhizomes: those unsavory characters who symbolize and embody the rhizome: women, minorities, Right-wing nuts.

Philosophy, as a discipline of thought is highly phallologocentric and antinomadic; it maintains a privilege bond to domination, power and violence and consequently requires mechanisms of exclusion and domination as parts of its standard practices. Philosophy creates itself through what it excludes as much as through what it asserts... The structural necessity of...pejorative figurations of otherness, makes me doubt the theoretical capacity; let alone the moral and political willingness, of theoretical discourse to act in a nonhegemonic, nonexclusionary manner. ${ }^{107}$

Teresa de Laurentis. Alice Doesn't: Feminism, Semiotics, Cinema. Bloomington, Ind.: Indiana University Press, 1984.

107

Braidotti (1994:33) emphasis added. 
Deleuze offered an alternate to this. In What is Philosophy? he refigures the work of the philosopher qua philosopher as the work of creating "new images of thought". ${ }^{10} \mathrm{An}$ image of thought is a rhizome which arrays an idea in such a way as to provoke the passage of pure difference so as to open the rest of us onto new possibilities for thought and for life. Although he identified high-profile characters in the history of philosophy as having created these images (Kant, Hume, Kafka, Spinoza), he did not describe the relationships of those individuals to those ideas as proprietary ones. Nor was Deleuze's work in these texts the work of avowal, filiality. An image of thought may be Spinozist or Proustian, but this identifies a style of effect which passes, not the owner of that concept. Dislocations between the person and "his" thoughts or "his" home or her "legacy"gives us all the gift of the possibility of a direct unmediated unworthy relation with something past, making it present again for us as a transient territory which we have a keen sense of, but no claims upon as possessions.

\section{Our Relations to Our Jobs}

I doubt if in my thesis I have created any new images of thought. Yet I have worked for years on this, and I work all day at this and other things and I get paid for it. What am I doing? What am I?

As a paid intellectlial I am functioning at and as the intersection of two

Let me point out that Deleuze, like some of his predecessors in the tradition (Nietzsche, Wittgenstein, Sartre and Heidegger) did not think that university departments of philosophy were necessarily the best places to generate these from. He did not reject a priori that these could not be. (That would be fascicular). But he saw a gap between the work of paid philosophers and the work of making concepts. Deleuze seemed to think that the makers of art were often more successful than the makers of books and conference papers in this task. What is Philosophy? Trans. Hugh Tomlinson and Graham Buchell. New York: Columbia University Press, 1994:34-50. 
arborescent lines: The history of philosophy itself, and its loyal transmission; and the discourse of intellectual property and its loyal transmission. Lacan says, viciously: "One remains loyal to tradition because one has nothing to say about the doctrine itself." ${ }^{109} \mathrm{My}$ analysis amends that to: "“...one also remains loyal to tradition when one has something to say about the doctrine itself since neither of these positionings subvert the basic proprietary arborescence of doctrine.

Using Foucault, we admit that it is not that the history of philosophy has produced Truth, and that that is, in fact, what each one of us in our cubicles is producing, bit by bit; rather, that the activities which we do bit by bit are taken to be the production of an extension of a history (and thus produces that history too), and also produce us, the specific intellectuals. Similarly, we are not making and claiming property but property is making good use of us. Looking at things from the point of view of power, everything is lined up so that we are fully inclined to reproduce and extend these lines. What is especially helpful about looking at the situation from the framework of cartography is that we know already that infinite deferral and referral are built into these lines. We spend a whole lifetime building up a dossier, building up a bibliography, building up enough credentials from which we can speak to and about the exact things which we understand ourselves to be compelled to address. But we never speak. I ask a colleague who is an "ethicist" how he behaves regarding the delicate matter of adultery. He replies that he has to read some more. I don't see this as mere hilarity, a Chaplinesque sketch of a cast of 
characters each one of us knows too well and joins. There is something terrible built into it: arborescence is apolitical and bourgeoise. Think of all the murderous decades which pass as liberalism spends itself "securing" an adequate subject who can then be the proper precondition for political engagement which can bring about its "promises". Foucault and Deleuze, in their discussion "Intellectuals and Power" emphasize that the key to any and all reform is to be a source of speaking. ${ }^{10}$ This 'source of speaking' is closely related to the space of recognition and reorganization Foucault affirmed. And both of these are organized by cartographic relations.

Consider the ways we use texts as if they were holy texts: modes of intellectual thinking, tones of discussion, habits of a body and its voices at a lecturn are "teleologically ordained..." and "encourage repetition and dutifulness...that enforce a sanctimoniousness and a sacredness of certain texts." "Thus one of the ways we readily extend the discourse of intellectual property is in this reverence for authorship, loyalty to reproduction, care with reputation. I am not certain that I am not doing this right now with Deleuze. I must truthfully admit that my copy of A Thousand Plateaus has the status of a fetish object for me. We also have to admit that we enact practices of fetishization and ownership between ourselves and our students, not just their "minds". Certainly this possessiveness is encouraged by the way universities set up departments and funding; however, even within those structures we can practice "healthy disavowals" like not 
assuming that everything they have to say about the world is a mirror of our own having "given" the world to them. In my experience, philosophy is especially and disturbingly prone to making these prideful patriarchal relations with its students, and in turn, these students make them among themselves. To my mind "stewardship model"or "leadership models" do not break with this basic alignment: they just rename the branches and make some of the segments longer.

These enactments are at least in part, narcissistic prostheses: they give us each a line on money or a name through a name. In these styles of transfer, we (or persons acting on "our behalf" like the copyright officer in the library) take on a policing function. This function is activated in the form of denying (implicitly or overtly) poorly aligned laypersons the right to embody and express self-ownership, and of invalidating their claims of self-knowledge. ${ }^{112}$ This function is extending itself more and more into the realm of material relations between biotech companies, medical authorities, persons and their genetic material.

How to move the intellectual toward rhizome/becoming: what methods and practices of property?

Now I have to say what it might mean for us to practice robust enough disavowals that the rhizome in thinking and history and books and in ourselves can do their thing. I need to preface this with Deleuze's cautions from "Micro politics and Segmentarity".

\section{Deleuze's cautions and what they mean here}

There are a few details from Deleuze we should not forget: First, that rhizomatic 
and arborescent lines are always in relation to one another; they "cut into" one another. As far as problems or their solutions go, we are never speaking of pure arborescence or pure rhizomatics, nor can "we say that one of these three lines is bad and another good, by nature and necessarily". ${ }^{113}$ Second, what Deleuze means when he says "something always escapes" is that we can tinker with the lines but that not all lines go through us; in other words, each problem is not a problem making its claim entirely on the human subject.

\section{First Danger: Fear and its Roots:}

The greatest danger that prevents us from moving from critique to action is fear. It is because of fear that arborescent lines dominate. Deleuze notes correctly that there is a great comfort in the security that rigidity offers ${ }^{1 / 4}$. It strikes us as better to hunker down in old stiff rooted zones, like personal identity, authorship and its ego-burnishing practices, marriage and its well-looked-upon rituals of deferral, parenthood, professorships, RRSP's and patrilineal baby naming, than to risk losing what those provide us in being with what they only promise in becoming. Perhaps this helps to explain why, even in the face of strong criticism, the standard academic methodologies that I discussed in the first chapter, are generally "preferred" to something like a postmodern approach?

As an untenured female professor with no rosy retirement picture yet to gamble, I know too well the practical, fear-supported impetus toward claiming and avowing, rather

Deleuze and Guattari, “Micropolitics and Segmentarity." (1987:227).

(ibid:95-101). 
than dispossessing and disavowing, what is mine as an intellectual history. Is this the "public" counter-point to the dangers, for women, of avowing maternality? At this moment in history, in North America, it is only a paid and positioned "intellectual"who is able to make systematic claims to what she is owed in alignments (money, reputation, office space, federal funding) amid the general yet-to-come truth-bearers. However, we must admit Braidotti's historically accurate point that not every subject stands in symmetrical relations to the securities of arborescent segments, ${ }^{115}$ thus, when speaking of this "danger" we must be sensitive to the fact that "the dangers" of clinging to something solid as compared to "the gains of" risking these will not be a standard equation across genders, class, race, etc. This suggests to me not that we shouldn't take risks, but that we can expect that those in more secure "locations" shoulder their share of burden of those risks. I think that fully-tenured, well-respected professionals should be the ones to initiate and publically exercise the kinds of suggestions I make here.

\section{Second Danger: Fascicles and their Clarity:}

Deleuze warns us about what he calls "the dangers of clarity". 16 An instance of clarity is the single-mindedness produced when one is seduced by binary ontology itself into thinking that a single, clear and effective means of subversion exists, and that it consists in replacing the affirmed half of the equation by what it negates. Braidotti calls

Braidotti (1994:118-9). 
this "replacing the Father tongue with the Mother tongue". "Thwarting arborescence in property is not, then, simply a matter of making private end runs around the larger, chunkier machinations of intellectual property like CanCopy. For example, photocopying whole books not covered by the CanCopy Licence on the department photocopy machine after hours. The small 'subverted lines' produced by these actions could very well be instances of what Deleuze called "fascicles". Fascicles are second-order arborescent lines made up of rigid supplementary segments. Fascicles aren't necessarily leading away from, or honoring an origin or Father Law, nor are they clearly geared toward "higher" authority. While not overtly part of an overall system, stylistically, are still bureaucratic; politically, are still fascistic. Because each one of them cartographically preserves the spirit of limit and center and goal; they still have, into themselves, a homogeneity and a unity which makes them "overcoded"."18 "This amounts to saying that the fasciculated system does not truly break with dualism, with the complementarity of subject and object, natural and intellectual reality."II9And, according to Foucault, these microzones can conserve the spirit of containment and monolinguilism even more strongly than when overtly connected to broader lines of propriety, partly because of the paranoia which accompanies having appropriated a larger center of authority and administration to oneself. This satisfies a third danger which Deleuze identifies: the danger of power. To

Braidotti (1994:11). 
break with proprietary relations requires making and being a part of rhizomatics not just littler trees.

\section{Fourth Danger: the Great Disgust}

An alternative reaction to the ubiquitous rigidities of the lines of property cutting across ones own zones and selfhood is what Deleuze calls "the Great Disgust". It takes a razor-sharp care, combined with perfect detachment, to pull the switch on an arborescent line and have it become rhizome. Deleuze calls this move "a line of flight". However, it is very easy for a line of flight to turn into "a line of death". A line of death is where you experience a total decompression, total loss of grounding in any place or event or shape for the future, and "turn to destruction, abolition pure and simple...". ${ }^{20}$ Nomads and rhizomes are linked to violence ${ }^{121}$ because the power that they roll through a zone is destabilizing, is against things staying the same. This violence can be redirected, though, toward the self and towards the whole field, rather than just toward changing its cartography in order for something else to come. In the domain of intellectual property, I think that the Great Disgust would consist in each one of us, in response to my analysis, taking it upon ourselves to simply destroy everything: the books we love too much, the universities we collect a pay cheque from, the teaching methods we use, the history we believed ourselves to be heirs to.

We don't get becoming from death, we get it by being stylish and creating "oases

Deleuze and Guattari (1987: 229).

121

Patton (1984:61-80). 
of non-belonging"122 in a supportive but not dominating relation to belonging. This maps nicely onto my assessment of the merits of a Sovereign regime of power, yet adds a more complex story about motives.

Free Thinking: the Intellectuals at a Potlatch?

Some (but not all) of what I suggest here as strategies of resistance should be understood as being in the spirit of the kinds of theatrical "parodic strategies" already suggested by many: Derrida, Debord, Baudrillard, Artaud, Butler, and Haraway ${ }^{123}$ to mention just a few. I also imagine I'll sound like the idealistic doctoral candidate that I am. Nevertheless, based on what I have assessed, these kinds of suggestions are in the direction of the rhizome. And based on my own experiences in academia over the past 20 years -- as a student, a scholar and a teacher -- not many of these are practiced:

- Co-and multiple authorship of papers. ${ }^{124}$

- Non-affliliation with Universities: more of the European model of "independent scholar" should be made possible.

122

Braidotti (1994:19-20).

123

Gary Genosko, "Empty Signs and Extravagant Objects." Baudrillard and Signs: Signification Ablaze. New York: Routledge, 1994:117-151; Guy Debord. The Society of the Spectacle. Detroit: Black and Red, 1983; Donna Haraway, "Ecce Homo, Ain't (Ar'n't) I a Woman, and Inappropriate/d Others: The Human in a PostHumanist Landscape." Feminists Theorize the Political. Ed. Joan Scott and Judith Butler. New York: Routledge, 1992:86-100; Judith Butler. Bodies That Matter: On the Discursive Limits of "Sex". New York: Routledge, 1993; also Excitable Speech: A Politics of the Performative. New York: Routledge, 1997; "Nietzsche, Genealogy, History" in Foucault (1984c); Antonin Artaud. Le Théâtre et son double. Paris: Gallimard, 1964.

124

See "Another Always Thinks in Me.", (written in parallel and sequential series) by Aden Evans, Mani Haghighi, Stacey Johnson, Gordon Thompson and Karen Ocana, in Deleuze and Guattari: New Mappings in Politics, Philosophy, and Culture. Ed. Eleanor Kaufman and Kevin Jon Heller, Minneapolis: University of Minnesota Press, 1998:270-280. 
- $\quad$ Pen names. ${ }^{125}$

- $\quad$ Circulation of papers without authorship.

- Organize circulation of ideas thematically, rather than based on personality, or "views held" by individuals.

- $\quad$ Permission to freely copy as default position, rather than present system, where permission to freely copy must be obtained. ${ }^{126}$

- Integrate tactile into visual and aural expression and transmission of ideas.

- A return to "orality": maximal transmission and minimal recording.

...as we saw from the specific analyses of potlatch and pregnancy, the hinge that shifts the epistemic field from knowers to authorities is the introduction of the means of tracing and marking. This is reaffirmed in the cartographic analyses of spaces of power and kinds of lines: when the means to mark is fixed in a particular array, the field can become reorganized around more hierarchical, less reciprocal, forms of power or types of lines.

\section{Conclusion: What cartographic analysis has gained for our understanding and responsibility to intellectual property:}

This theses is not "non-obvious", "useful in a practical sense", or "novel"; nor can

I promise that it will enable any "skilled recipient" to do much with it. ${ }^{127}$ I have simply

Foucault himself published an entry about "the work of Michel Foucault" in the French Dictionarv of Philosophers under the name "Maurice Florence" (cited in Flaubion's "Introduction" to Foucault (1998:xiv)).

126

A exactly parallel solution has been argued for a problem which, at first glance, seems entirely removed from the present inquiry: how to increase the supply of organs available for transplants? Rupert Jarvis (in "Join the Club: A Modest Proposal to Increase Availability of Donor Organs." Readings in Health Care Ethics. Ed. Elizabeth Boetzkes and Wil Waluchow, Broadview, 2000:331-338) argues that North America should follow the examples set by certain European countries [Denmark, Austria, Sweden...] and change our system from one where evidence for willingness to donate organs must be found on the dead person, to one where, in the absence of evidence to the contrary (non-voluntarism or what Jarvis calls "opting out") all medically and ethically-sound potential donor "opportunities" are presumed acceptable to harvest. In fact, this case is not so unrelated to the one at hand regarding knowledge and its transmission. There isn't a "shortage" of knowledge, but the uses that can be made of it are circumscribed by norms of property and propriety.

127

These are the four criteria according to which an invention is determined as patentable by the U.S. Patent and Trademark Office. That is to say, these criteria are used to differentiate "raw products of nature" such as the ideas I had before I wrote them down, from "human products' which can be privately owned. "It's usually when these [DNA] products have been isolated, purified, or modified to produce a unique form not found in nature that they become patentable." ("Human Genome Project Information on Genetics and Patenting.", http:/www.oml.gov./hgmis/elsi/patents.html.). With respect to the criterion of usefulness, I hope I have taken 
tried to situate some of the issues involved in the privatization of ideas within the area of contemporary post-structuralist cartographic analysis. ${ }^{128}$ What allowed me to do this was to deconstruct the so-called "public/private" distinction, using personal and historical examples, to uncouple that base binary and to dislodge it from an arborescent line of history. I have chosen this methodological approach both to try to show how poststructuralist analysis might help us understand property differently than other perspectives do. Most importantly, I have tried to show how it can be used to generate critical, evaluative principle about what we should do or say, as an adequate reply to contemporary issues relating to intellectual property which have preoccupied me for a long time. In this last chapter, I presented Foucault's regimes of power as cartographic principles, and also presented Deleuze's by now fairly familiar concepts of "rhizome"and "arborescent" lines. I used these principles to reveal the workings of our positionality as academics; to situate our own "location", as academics, in the production and ownership of ideas and a subjectivity which occupies that position. My ultimate aim was to draw out some critical reflections about that situatedness, again, borrowing from Deleuze's account of the political and ethical styles which accompany "the rhizome" as compared to

something from Deleuze and shown how it can be applied, or used, to do something else. Deleuze might have chastised me for doing little more with his thought than extracting and applying it, since he set the bar very high for what it meant to "do philosophy" (What is Philosophy?. Trans. Hugh Tomlinson and Graham Burchell. New York: Columbia, 1994b:1-1 13.). However, elsewhere, he has, notoriously, invited us to use his tools; indeed to use the whole of philosophy as a toolbox to have our way with. ("Intellectuals and Power." Language, Counter-memory, practice. Trans. Donald Bouchard and Sherry Simon. Ed. Donald Bouchard. Ithaca: Cornell University Press, 1977:208; "Letter to a Harsh Critic." Negotiations. Trans. Martin Joughin. New York: Columbia University Press , 1995:6.) If I cannot claim that this use is doing philosophy; my methods might open toward an image of thought.

128

This style of analysis has also been referred to as: schizo-analysis, micropolitics, pragmatism, diagrammatics, rhizomatics (Deleuze and Guattari (1983a:72)). 
"the arborescent", and reading from Foucault what he had to say about the relative repressiveness of the various power regimes.

This thesis was entered into eight years ago, driven by a set of questions regarding what my "responsibility" in light of trends in the privatization of ideas involved. It is vitally important for academics to rethink their situation and their practices within larger relations which privatize knowledge. This thesis' end honors its initial worries.

Cartographic analysis has sketched an answer, albeit in a very complicated fashion. Cartographic analysis forces us to "rethink" our situation and our practices in novel ways.

First, it reframes the field such that intellectuals are fully within rather than external to, and merely commenting upon ${ }^{129}$ the discourse of property in ideas. It alters the scale and style of our approbation or disapproval: it is not that intellectual property regimes can be said to be good or bad from an overall position but we can and ought to say, about our own positionality in "regional power systems"130 (Universities) what that positioning contributes to the dynamic of the discourse. Second, and relatedly, since its chief axis differentiates lines which undergird and extend proprietary relations from those which do not, we are forced to acknowledge here that personal intentionality, having an intense desire to trespass or transgress, ${ }^{\mathrm{t} 31}$ such as privatization of biological material - is not a fully adequate response to the issues. The cartographic function of the intellectual,

Foucault (1999:3).

130

$$
\text { Deleuze and Foucault (1977:207). }
$$

131

$$
\text { Contra Braidotti (1994:36). }
$$


within the dornain of property in ideas, operates "in a more profound and diffuse manner than our interests dictate". ${ }^{132}$ Foucault taught us to be on the lookout for instances where one thing is being claimed or disavowed yet, simultaneously, the exact opposite is being enabled. Sometimes enabled because of the disavowals, not in spite of them. He politely called these "inversions". ${ }^{133}$ To conceive of ourselves and to act as if the role of the intellectual vis-a-vis the questions of ownership in ideas and innovations was one of "a representative of consciousness and truth", does not prevent us from being "objects and instruments" of the discourse of property, from being key, rather than marginal figures in "systems of power, blocks, prohibitions and invalidations." 134 I hope that I have shown how, historically and contemporaneously, that conception enables these functions.

More graphically, the intellectual part of the term intellectual property, "exercises a function that traditionally belonged to the police" and does this because, as I argued, it extends an arborescent line. In an equally uncomfortable assessment, this analysis forces me to consider the ways in which similarly structured claims to authority in the "private realm", as mothers-to-be, and mothers-with-children extends that realm as a place where similarly self-promoting and controlling activities are fostered and protected from censure.

Lastly, what is novel about using a cartographic analysis to see the whole field of

Deleuze and Foucault (1977:215).

Foucault (1990a:81). 
property prevents us from drawing false sub-distinctions across the wide range of techniques and roles which make up that field; for instance, "CanCopy" as if strictly unrelated to "genetic sequence patents", "the Arts" as if distinctly opposed to "Scientific Research", "mothers" as if opposed to "managers", "students" as if opposed to "products" or "possessions" and especially, "teaching" as if opposed to "selling". I have suggested some of the ways in which we might change positions - as shapes or as lines - and thus free thinking. This is possibly even more important in the machinations of the private than those of the public.

It is my hope that the overall effect of this thesis has been to provoke the uneasy suspicion that what is called "thinking" and what is called "owning" are not, in fact, diametrically opposed terms but rather can be said to often occupy the same positions within late capitalism. And, that cherished values such as freedom and creativity have more to do with an intimate, local and on-going rearrangement of these relations than the liberal paradigm we find ourselves in suggests. If, using non-oppositional thinking, I have managed to awaken us to the fact that oppositional logic will not free us from the dangers which this ever-expanding discourse presents - both personally and globally - then something in this arrangement of words has done some work.

K. Houle/August 2001. 


\section{BIBLIOGRAPHIC REFERENCES}

Abbot, F.M.

1989 "Protecting First World Assets in the Third World: Intellectual Property Negotiations in the GATT Multinational Framework." Vanderbilt Journal of Transnational Law 22:4, 705-710.

Agamben, Giorgio

1993 The Coming Community. Translated by Michael Hardt. Minneapolis: University of Minnesota Press.

Alcoff, Linda and Vrinda Dalmiya

1993 “Are Old Wives' Tales Justified?" Feminist Epistemologies. Edited by Linda Alcoff and Elizabeth Potter. New York: Routledge, 217-244.

1996 Real Knowing: New Versions of the Coherence Theory. Ithaca: Cornell University Press.

Althusser, Louis

1972 Lenin and Philosophy, and Other Essays. Monthly Review Press, 1972.

Anderson, Elizabeth S.

1990 "Is Women's Labor a Commodity?" Philosophy and Public Affairs 19:1, 71-92.

Arditti, Rita, et al., eds.

1984 Test-Tube Women. London: Pandora Press.

Arendt, Hannah

1958 The Human Condition. Chicago: University of Chicago Press.

Ariès, Phillipe.

1962 Centuries of Childhood: A Social History of Family Life. Translated by Robert Baldick. New York: Knopf.

Aristotle

1941 The Basic Works of Aristotle. Edited by Richard McKeon. New York: Random House.

Artaud, Antonin

1964 Le Théâtre et son double. Paris: Gallimard.

Barnett, H.G.

1938 "The Nature of the Potlatch." American Anthropologist 40, 349-358.

Bartky, Sandra Lee

1988 "Foucault, Feminity, and the Modernization of Patriarchal Power." Feminism and Foucault. Edited by Irene Diamond and Lee Quinby. Boston: Northeastern, 61-86.

1990 Femininity and Domination: Studies in the Phenomenology of Oppression. New York: Routledge, Chapman, and Hall, Inc.

2000 "The Making and Unmaking of a Feminine Self", Keynote paper delivered at the Atlantic Region Philosopher's Association Conference October $13^{\text {th }}$, King's College, Halifax, Canada.

Bataille,Georges 
1988 The Accursed Share: Volume One. Translated by Robert Hurley. New York: Zone Books.

Baudrilliard, Jean

1991 La Guerre du Golfe N'a Pas eu Lieu. Paris: Édition Galilée.

1995 The Gulf War did not Take Place. Translated by Paul Patton. Indianapolis, Ind.: Indiana University Press.

Baugh, Bruce

1993 "Deleuze and Empiricism." Journal of the British Society for Phenomenology. 24:1,15-31.

Benhabib, Seyla

1995 "Feminism and Postmodernism: An Uneasy Alliance." Feminist Contentions. New York:

Routledge, 17-34.

1998 "Models of Public Space: Hannah Arendt, the Liberal Tradition, and Jurgen Habermas." Feminism and Politics, Edited by Anne Phillips. Oxford: Oxford University Press, 65-99.

Benjamin, Jessica

1988 The Bonds of Love. New York: Pantheon.

Bentham, Jeremy

1978 "Principles of the Civil Code" in Property: Mainstream and Critical Positions. Edited by C.B.

Macpherson. Toronto: University of Toronto Press, 41-58.

Bettig, Ronald V.

1996 Copyrighting Culture: The Political Economy of Intellectual Property. Boulder, Co.: Westview.

Blackstone, William

1979 Commentaries on the Laws of England. Chicago and London: University of Chicago Press.

Boas, Franz

1897 "The Social Organization and the Secret Societies of the Kwakiutl Indians." Report of the U.S.

National Museums for 1895 . Washington, D.C., $311-338$.

1940 Race, Language, Culture. New York: Macmillan.

Bordo, Susan

1989 "The Body and the Reproduction of Femininity: A Feminist Reappropriation of Foucault."

Gender/Body/Knowledge: Feminist Reconstructions of Being and Knowing. Edited by Susan Bordo and Alison Jaggar. New Jersey: Rutgers University Press, 13-33.

1990 "Reading the Slender Body." Body/Politics. Edited by Mary Jacobus, Evelyn Fox Keller and Sally Shuttleworth. New York: Routledge, 83-112.

Boundas, Constantin V., and Dorothea Olkowski, eds.

1994 Gilles Deleuze and the Theater of Philosophy. New York: Routledge.

Bourdieu, Pierre

1977 Afterword to Reflections of Fieldwork in Morocco. Paul Rabinow. Berkeley: University of California Press:163-165. 
Braidotti, Rosi

1991 Patterns of Dissonance. Great Britain: Polity Press.

1994 Nomadic Subjects: Embodiment and Sexual Difference in Contemporary Feminist Theory. New York: Columbia University Press.

Brettell, C. and C. Sargent, eds.

1996 Gender in Cross-Cultural Perspective, $2^{\text {nd }}$ edition. New Jersey: Prentice-Hall.

Butler, Judith

1989 "Sexual Ideology and Phenomenological Description: A Feminist Critique of Merleau-Ponty's Phenomenology of Perception." The Thinking Muse. Edited by Jeffner Allen and Iris Marion Young. Indiana University Press, 85-100.

1990 Gender Trouble: Feminism and the Subversion of Identity. New York: Routledge.

1993 Bodies That Matter: On the Discursive Limits of "Sex". New York: Routledge.

1995 "Contingent Foundations: Feminism and the Question of 'Postmodernism'." Feminist Contentions: A Philosophical Exchange. New York: Routledge, 35-57.

1997 Excitable Speech: A Politics of the Performative. New York: Routledge

Butler, Melissa A.

1991 "Early Liberal Roots of Feminism: John Locke and the Attack on Patriarchy." Feminist Interpretations and Political Theory. Edited by Mary Lyndon Shanley and Carole Pateman. Penn State University Press, 74-94.

Canadian Panel of Violence Against Women.

1993 "Changing the Landscape: Ending Violence-Achieving Equality. Final Report." Ottawa: Minister of Supply and Services.

Child, James W.

1990 "The Moral Foundations of Intangible Property." The Monist 73:4, (October):578-600.

Chin and Grossman

1988 Intellectual Property Rights and North-South Trade.

Clark, Christopher

1995 "Legal Update: Intellectual Property." Canadian Lawyer (February):38-44.

Code, Lorraine

1995 Rhetorical Spaces: Essays on Gendered Locations, New York, Routledge.

Codere, Helen

1956 "The Amicable Side of Kwakiutl Life: The Potlatch and the Play Potlatch." American

Anthropologist 58, 334-350.

1966 Fighting with Property. Seattle: University of Washington Press. 
Collard, David

1978 "Blood and the Gift Relationship." Altruism and Economy. Edited by David Collard. Oxford: Martin Robertson, 140-150.

Corea, Gena, et al., eds.

1985 Man-Made Woman. London: Hutchinson.

Cornell, Drucilla

1987 "Feminism, Negativity, Inter-subjectivity." (co-authored with Adam Thurschwell.) Feminism as

Critique. Edited by Seyla Benhabib and Drucilla Cornell. Minnesota: Polity Press.

1995 "What is Ethical Feminism?" Feminist Contentions. New York: Routledge:75-106.

Couzens Hoy, David, ed.

1986 Foucault: A Critical Reader. Oxford: Basil Blackwell

Curtis, Michael, ed.

1981 The Great Political Theories, Vol. I. New York: Avon

Daniels, Pete

1993 "Technology and Ethics in Agriculture." Joumal of Agricultural and Environmental Ethics : 52-59.

de Certeau, Michel

1988 The Writing of History. Translated by Tom Conley. New York: Columbia University Press.

de Beauvoir, $\mathbf{S}$.

1989 The Second Sex. Translated by H.M. Parshley. New York: Vintage.

Debord Guy

1983 The Society of the Spectacle. Detroit: Black and Red.

DeLanda, Manuel

1991 War in the Age of Intelligent Machines. New York: Zone Editions.

de Laurentis, Teresa

1984 Alice Doesn't: Feminism, Semiotics, Cinema. Bloomington, Ind.: Indiana University Press.

Deleuze, Gilles, and Felix Guattari

1972 Capitalisme et schizophrénie tome 1: l'Anti-Oedipe. Paris: Éditions de Minuit

1980 Mille Plateaux. Paris: Éditions de Minuit.

1983a On the Line. Translated by John Johnston. New York: Semiotext(e).

1983b Anti-Oedipus: Capitalism and Schizophrenia. Translated by Robert Hurley, Mark Seem and Helen R. Lane. Preface by Michel Foucault. Minneapolis: University of Minnesota Press.

1987 A Thousand Plateaus. Translated by Brian Massumi. Minneapolis: University of Minnesota Press.

Deleuze, Gilles, and Michel Foucault

1972 "Les intellectuals et le pouvoir." L'Arc 49: Deleuze 3-10. 
1977 "Intellectuals and Power." Michel Foucault: Language, Counter-Memory. Practice. Translated by Donald F. Bouchard and Sherry Simon. Edited by Donald F. Bouchard. Ithaca: Cornell University Press, 205-217.

Deleuze, Gilles, and Claire Parnet

1977 Dialogues. Paris: Flammarion.

1987 Dialogues. Translated by Hugh Tomlinson and Barbara Habberjam. New York: Columbia University Press.

Deleuze, Gilles

1968 Différence et répétition. Paris: Presses Universitaires de France.

1969 Logique du sens. Éditions de Minuit.

1981 Spinoza: Philosophie pratique. Paris: Éditions de Minuit.

1986 Foucault. Paris: Éditions de Minuit.

1988a Foucault. Translated by Seán Hand. Forward by Paul Bové. Minneapolis: University of Minnesota Press.

1988b Spinoza: Practical Philosophy. Translated by Robert Hurley. San Francisco: City Lights Books.

1990 The Logic of Sense. Translated by Mark Lester with Charles Stivale. Edited by Constantin V. Boundas. New York: Columbia University Press.

1991 a Empiricism and Subjectivity: An Essay on Hume's Theory of Human Nature. Translated by Constantin V. Boundas. New York: Columbia University Press.

199 lb Qu'est-ce que la philosophie?. Paris: Éditions de Minuit.

1994a Difference and Repetition Translated by Paul Patton. New York: Columbia University Press.

1994b What is Philosophy? Translated by Hugh Tomlinson and Graham Burchell. New York: Columbia

1995 Negotiations. Translated by Martin Joughin. New York: Columbia University Press.

1997 Essays: Critical and Clinical. Translated by Daniel W. Smith and Michael A. Greco. Minneapolis: University of Minnesota Press.

DerDerian, James

1990 "The (S)pace of International Relations: Simulations, Surveillance and Speed." International Studies Quarterly 34:295-310.

Derrida, Jacques

1974 Glas. Éditions Galilée.

1979 Spurs: Nietzsche's Styles. Translated by Barbara Harlow. Chicago: University of Chicago Press.

1984 "No Apocalypse, Not Now (full speed ahead, seven missiles, seven missives)." Translated by 
Catherine Porter and Philip Lewis. diacritics 14:2, 20-31.

1986 Glas. Translated by John P. Leavey Jr. and Richard Rand. Lincoln, Neb.: University of Nebraska Press.

1989 "Psyche: Inventions of the Other." Translated by Catherine Porter. in Reading de Man Reading. Edited by Lindsay Waters and Wlad Godzich. Minneapolis: University of Minnesota Press, 25-65.

1992 Given Time: I. Counterfeit Money. Translated by Peggy Kamuf. Chicago: University of Chicago Press.

1997 "Oligarchies: Naming, Enumerating, Counting." Politics of Friendship. Translated by George Collins. London: Verso, 1-25.

Dietz, Mary

1998 "Citizenship with a Feminist Face." Feminism: The Public and the Private, Edited by Joan Landes. Oxford: Oxford University Press, 45-64.

Dinnerstein, Dorothy

1977 The Mermaid and the Minotaur. New York: Harper Collophon.

Douglas, Mary

1990 Introduction to The Gift. Marcel Mauss. New York: Norton.

Dover, Kenneth James

1968 Lysias and the corpus Lysiacum. Berkeley, University of California Press.

Drahos, Peter

1996 A Philosophy of Intellectual Property. Brookfield, Vt.: Dartmouth Press.

Dreyfus, Hubert L. and Paul Rabinow

1983 Michel Foucault: Beyond Structuralism and Hermeneutics, $2^{\text {nd }}$ Edition. Chicago: University of Chicago Press.

Drucker, $\mathbf{S}$.

1952 "Rank, Wealth, and Kinship in North West Coast Society." American Anthropologist 55: 220-232.

Dumm, Thomas L.

1993 "Telefear: Watching War News" The Politics of Everydav Fear. Edited by Brian Massumi. Minneapolis: University of Minnesota Press, 3 07-321.

Dworkin, G. A.

1977 Markets and Morals. Washington, D.C.: Hemisphere.

Eckermann, Liz 1997 "Foucault, Embodiment and Gendered Subjectivities: the Case of Voluntary Self-Starvation." Foucault: Health and Medicine. Edited by Alan Petersen and Robin Bunton. New York: Routledge, 151169.

Eibl-Eibesfeldt, Irenaus

1975 Ethnology. Translated by Erich Klinghammer. New York: Holt, Reinehart and Winston. 
Eliade, Mircea

1959 The Sacred and the Profane: The Nature of Religion. New York: Harcourt Brace Jovanovitch.

Ellickson, Robert C.

I993 "Property in Land." Yale Law Journal. 102:1315-1400.

Elshtain, Jean Bethke

1981 Public Man, Private Woman. Princeton, N.J.: Princeton University Press.

Engels, Frederick

1972 The Origin of the Family, Private Property, and the State. New York: Pathfinder Press.

Epstein, Richard A.

1994 "On the Optimal Mix of Private and Common Property." Social Philosophy and Policy $11: 2,17-41$.

Erbish, F.H. and K.M. Mareida, eds.

1998 Intellectual Property Rights in Agricultural Biotechnology. New York: CAB International.

Evans, Aden, et al.

1998 "Another Always Thinks in Me." Deleuze and Guattari: New Mappings in Politics, Philosophy, and Culture. Edited by Eleanor Kaufman and Kevin Jon Heller. Minneapolis: University of Minnesota Press, 270-280.

Filmer, Robert

1949 Patriarcha and Other Political Works. Edited by Peter Laslett. Oxford: Blackwell.

Finley, M.I.

1980 Ancient Slavery and Modem Ideology. London: Penguin.

Fox Keller, Evelyn

1984 Reflections of Gender and Science. New Haven, Conn.:Yale University Press.

Foucault, Michel

1961 Folie et deraison. Histoire de la folie a l'âge classique.

1966 Let Mots et Les Choses. Une archéologie des sciences humaines. Paris: Éditions Gallimard.

1969 L'Archeologie du Savoir.

[970 The Order of Things: An Archeology of the Human Sciences. New York: Vintage.

1971 L'ordre du discours. Paris: Gallimard.

1972 The Archeology of Knowledge and "The Discourse on Language"(Appendix). Translated by A.M. Sheridan. New York: Pantheon

1973 Moi, Pierre Riviere, ayant egorge ma mere, ma soeur et mon frere... Un cas de parracide au XIXe siecle.

1975 Surveiller et punir. Naissance de la prison. Paris: Éditions Gallimard. 
1976 Histoire de la sexualité 1. La volonté de savoir. Paris: Éditions Gallimard.

1977 Language, Counter-memory, practice. Translated by Donald Bouchard and Sherry Simon. Edited by Donald Bouchard. Ithaca: Cornell University Press.

1979 Discipline and Punish: The Birth of the Prison. Translated by Alan Sheridan. Vintage: New York.

1980a The History of Sexuality, Volume One. Transla:ed by Robert Hurley. New York: Vintage

1980b Power/Knowledge: Selected Interviews and Other Writings, 1972-1977. Edited by Colin Gordon. New York: Pantheon.

1983a "The Subject and Power." Afterword to Michel Foucault: Beyond Structuralism and Hermeneutics, $2^{\text {nd }}$ edition. Edited by Hubert Dreyfus and Paul Rabinow. Chicago: University of Chicago Press, 208-226.

1983b Preface to Gilles Deleuze and Felix Guattari, Anti-Oedipus: Capitalism and Schizophrenia. Translated by Robert Hurley, Mark Seem and Helen R. Lane. Minneapolis: University of Minnesota Press.

1983c This is not a Pipe. Translated by James Harkness. Berkeley: University of California Press.

1984a Histoire de la sexualité 2: L'usage des plaisirs. Paris: Éditions Gallimard.

1984b Histoire de la sexualité 3: Le souci de soi. Paris: Éditions Gallimard.

1984c The Foucault Reader. Edited by Paul Rabinow. New York: Pantheon.

1985 History of Sexuality, Volume Two: The Use of Pleasure. Translated by Robert Hurley. New York: Random House.

1986 History of Sexuality, Volume Three: The Care of the Self. New York: Random House.

1987 Maurice Blanchot: The Thought from Outside. New York: Zone Books.

1988a Madness and Civilization: A History of Insanity in the Age of Reason. Translated by Richard Howard. New York: Vintage.

1988b Michel Foucault: Politics, Philosophy, Culture: Interviews and Other Writings 1977-1984. Edited by Lawrence D. Kritzman. New York: Routledge

1989 Resumé des Cours: 1970-1982. Paris: Julliard.

1990b The Use of Pleasure: The History of Sexuality. Volume Two. Translated by Robert Hurley. New York: Vintage.

1991 Remarks on Marx. Translated by R. Jamese Goldstein and James Cascaito. New York: Semiotext(e).

1994a The Birth of the Clinic. Translated by A.M. Sheridan Smith.. New York: Vintage.

1994b The Final Foucault, $3^{\text {rd }}$ edition. Edited by James Bernauer and D. M. Rasmussen. Cambridge, Mass.: M.I.T. Press. 
1994c Dits et Écrits: 1954-1988. Paris: Éditions Gallimard.

1995 I, Pierre Riviere, having slaughtered my mother, my sister and my brother.... Translated by Frank Jellinek. New York: Pantheon.

1996 Foucault Live. Edited by Sylvère Lotringer. Translated by Lysa Hochroth and John Johnston. New York: Semiotext(e).

1997 The Essential Works of Michel Foucault: 1954-1984, Volume One: "Ethics: Subjectivity and Truth". Edited by Paul Rabinow. Translated by Robert Hurley and others. New York: The New Press.

1998 The Essential Works of Michel Foucault: 1954-1984, Volume Two: "Aesthetics, Method and Epistemology". Edited by James D. Faubion. Translated by Robert Hurley and others. New York: The New Press.

1999 "The Order of Discourse." Translated by Cyril Welch. (private folio).

Franke, Linda Bird

1985 "The Ambivalence of Abortion." The Gender Reader. Edited by Evelyn Ashton-Jones and Gary Olson. Toronto: Allyn and Bacon, 464-468.

Franklin, Charles

1984 "Issue Preferences, Socialization, and the Evolution of Party Identification." American Journal of Political Science 28: 459-78.

Fraser, Nancy

1981 "Foucault on Modern Power: Empirical Insights and Normative Confusions." Praxis

International 1:3, (October):272-287.

1996 Justice Interruptus. New York: Routledge.

Freud, Sigmund

1943 "On Sexuality." The Standard Edition of the Complete Psychological Works of Sigmund Freud. Volume 21. James Strachey, ed. London: Hogarth Press.

1946 Totem and Taboo. Translated by A.A. Brill. New York: Vintage.

1961 Five Lectures on Psycho-analysis. Translated and edited by James Strachey. New York: W. W. Norton.

1961 Civilization and its Discontents. Translated and edited by James Strachey. New York: Norton..

Friedman, David

1994 “A Positive Account of Property Rights." Social Philosophy and Policy 11:2, 1-16.

Gadol, Joan Kelly

1987 "The Social Relation of the Sexes." Feminism and Methodology. Edited by Sandra Harding. Indiana University Press, 15-28.

Gasché, Rudolph

1997 "Heliocentric Exchange." The Logic of the Gift. Edited by Alan D. Schrift. New York: Routledge, 
100-117.

Genosko, Gary

1994 Baudrillard and Signs: Signification Ablaze. London; New York : Routledge.

1998 Undisciplined theory. London; Thousand Oaks, Calif. : Sage Publications.

Gibson, Mary

1991 "Contract Motherhood: Social Practice in Social Context", Women and Criminal Justice 3:1, 55-99.

Gleick, James

1999 Faster: The Acceleration of Just About Everything. New York: Pantheon.

2000 "Patently Absurd." New York Sunday Times Magazine. (March 12):44-49.

Goldberg, Jeffrey

1999 "The Color of Suspicion: What Cops Talk About When they Talk about Race." New York Times Magazine (June 20):50-64;85-87.

Goldberg, Ken, ed. 2000 Telerobotics and Telepistemology in the Age of the Internet. M.I.T. Press.

Goldman, Francisco. 2000 "Cape Fear." Bookforum 7:1, 33-34.

Goodchild, Philip 1996 Deleuze and Guantari: An Introduction to the Politics of Desire. London: Sage.

Goodrich, Peter and David Carlson, eds. 1998 Law and the Postmodern Mind: Essays on Pyschoanalysis and Jurisprudence. Ann Arbor, Mich.: University of Michigan Press.

Gourevitch, Philip 1995 "Letter from Rwanda: After the Genocide." The New Yorker (December 18th):78-95.

Guattari, Felix

1986 “1985: Microphysique des Pouvoirs et Micropolitique des Desirs." 1980-1985: Les Annees d'Hiver. Paris: Barrault.

1989 1980-1985: Les Annees D'Hiver. Paris: Barrault

1995 Chaosophy. Edited by Sylvere Lotringer. New York: Semiotext(e).

1996 The Guattari Reader. Edited by Gary Genosko. Cambridge, Mass. : Blackwell Publishers.

Habermas, Jürgen

1970a Knowledge and Human Interest. Boston: University of Boston Press.

1970b “A Theory of Communicative Competence." Recent Sociology No.2. Edited by H.P.Dreitzel. New York: Macmillan 
Hacking, lan

1990 The Taming of Chance. Cambridge: Cambridge University Press, 1990.

Halliday

1890, 1906, 1909 Canadian Indian Affairs Annual Report.

Hankinson Nelson, Lynn.

1993 "Epistemological Communities." Feminist Epistemologies. Edited by Linda Alcoff and Elizabeth Potter. New York: Routledge, 121-159.

Hansmann, Henry

1989 "The Economics and Ethics of Markets for Human Organs." Journal of Health Politics. Policy and Law 14: $57-85$.

Haraway, Donna

1994 “Ecce Homo, Ain't (Ar'n't) I a Woman, and Inappropriate/d Others: The Human in a Post-

Humanist Landscape." Feminists Theorize the Political. Edited by Joan Scott and Judith Butler. New York: Routledge: 86-100.

1997 Modest Witness@Second Millennium.FemalMan-Meets-OncoMouse: feminism and technoscience. New York: Routledge

Hardt, Michael

1989 "Mercantilist Bargaining and the Crisis in the Multilateral Trade System: Finding a Balance between Domestic and Foreign Trade Policy." Occasional Papers in International Trade Law and Policy /Center for Trade Policy and Law 4:1-39.

Hardt, Michael

1998 "The Withering of Civil Society." Deleuze and Guattari: New Mappings in Politics, Philosophy and Culture. Edited by E. Kauffman and K.J. Heller. Minneapolis: University of Minnesota Press, 23-39.

Harding, Sandra

1991 Whose Science? Whose Knowledge? thaca: Cornell University Press.

1993 "Rethinking Standpoint Epistemology." Feminist Epistemologies. Edited by Linda Alcoff and Elizabeth Potter. New York: Routledge, 49-82.

Hargrove, Eugene

1989 Foundations of Environmental Ethics. Englewood Cliffs, N.J.: Prentice-Hall.

Hartmann, Heidi I.

1981 "The Unhappy Marriage of Marxism and Feminism." Women and Revolution. Edited by Lydia Sargent.Boston: South End Press.

1987 "The Family as the Locus of Gender, Class and Political Struggle: The Example of Housework." in Feminism and Methodology. Edited by Sandra Harding. Indiana University Press: 109-134.

Hartsock, Nancy

1990 "Foucault on Power: A Theory for Women?" Feminism/Postmodernism. Edited by Linda J. 
Nicholson. New York: Routledge: 157-175.

Hegel, G.W.F.

1989 The Phenomenology of Spirit. Translated by J.L.H. Thomas. Reprinted in Hegel: Selections. Edited by M.J. Inwood. New York: Macmillan.

Heidegger, Martin

[968 "What is Called Thinking? Translated by J. Glenn Gray. New York: Harper and Row.

1976 The Collected Works of Martin Heidegger. Frankfurt am Main: Klosterman.

Heraclitus

1966 Fragment $108 \&$ 109, The Presocratics, Edited by Phillip Wheelwright. New York: Macmillan.

Hirschon, Renée, ed.

1984 Women and Property-Women as Property. London: Croom Helm.

Hitt, Jack

2000 "Marriage à la Market." The New York Time Magazine (March 19th):17-18.

Holcombe, Lee.

1983 Wives and Property: Reform of the Married Women's Property Law in Nineteenth-Century England. Oxford: Martin Robertson.

Holdsworth, W.S.

1937 A History of English Law, 2nd Edition. London: Sweet and Maxwell.

Holton, Gerald, Hasok Chang, and Edward Jurkowitz

1996 "How a Scientific Discovery is Made: A Case History." American Scientist 84, (July-August):364375.

Houle, Karen

1998 "Antiporn Cons and Pros: How Long is the Arm of the Law?" International Studies in Philosophy 30:1, 79-90.

2000 "Micro politics and Property: Deleuze and Foucault on Common Ground." International Studies in Philosophy 32:1, 113-122.

Hrdy, Sarah Blaffer

2000 Mother Nature: A History of Mothers, Infants, and Natural Selection. New York: Pantheon.

Hugill, Peter J.

1989 "Home and Class among American Landed Elite." The Power of Place: Bringing Together Geographical and Sociological Imaginations. Edited by John A. Agnew and James Duncan. Boston: Unwin Hyman, 1989:66-78.

IDRC Report

1995 23:1, (April):22-23.

Irigaray, Luce

1985 Speculum of the Other Woman. Translated by Gillian C. Gill. Ithaca, N.Y.: Cornell University Press. 
1997 "Women on the Market." The Logic of the Gift. Edited by Alan Shrift. New York: Routledge, 174189.

Jackson, Wes, Wendell Berry and Barry Coleman, eds.

1984 Meeting the Expectations of the Land. Berkeley: North Point Press.

Jacobs, Sheldon

1994 "An Update and Overview of Inteilectual Property Rights in Thailand." Office of the Board of Investment, Office of the Prime Minister, Royal Thai Government, 28pp.

Jaggar, Alison

1989 "Love and Knowledge: Emotion in Feminist Epistemology." Women, Knowledge and Reality. Ann Garry and Marilyn Pearsall, eds. Boston: Unwin Hyman, 166-190.

Jameson, Frederic 1997 "Marxism and Dualism." A Deleuzian Century? Special Edition of The South Atlantic Quarterly $96: 3,393-416$

Jefferson, Thomas 1975 The Portable Jefferson. Edited by Merril D. Peterson, New York: Viking.

Jarvis, Rupert

2000 "Join the Club: A Modest Proposal to Increase Availability of Donor Organs." Readings in Health Care Ethics. Edited by Elizabeth Boetzkes and Wil Waluchow, Broadview:33 l-338.

Jonas, Hans

1984 The Imperative of Responsibility. Chicago: University of Chicago Press.

Kaufman, E. and K.J. Heller, eds. 1998 Deleuze and Guattari: New Mappings in Politics, Philosophy and Culture. Minneapolis: University of Minnesota Press.

Keyman, Emin Fuat 1988 "Mapping the Concept of Modern: Three Discursive Positions of Epistemology and the Uniqueness of Western Capitalism." Department of Political Science, Carleton University Occasional Papers 16, (April): $1-46$.

Kingston, William

1990 Innovation, Creativity and Law. Boston: Kluwer.

Knudson, Mary, and LeRoy Hansen 1991 "Intellectual Property Rights and the Private Seed Industry." U.S. Department of Agriculture, Agriculture Economics Report No. 654 (November): 19pp.

Kuhn, Thomas S.

1977 The Essential Tension : Selected Studies in Scientific Tradition and Change. Chicago : University of Chicago Press, 1977.

Kurtz, Mordechai

1977 "Altruistic Equilibrium." Economic Progress, Private Values and Public Policy. Edited by B. Balassa 
and R. Nelson. New York: North-Holland, 177-200.

Lacan, Jacques

1977 Écrits. Translated by Alan Sheridan. New York: Norton.

Ladner, Joyce

1972 Tomorrow's Tomorrow: The Black Woman. Garden City, N.J.:Doubleday.

Lal, Jayati

1999 "Situating Locations: The Politics of Self, Identity and "Other" in Living and Writing the Text."

Feminist Approaches to Theory and Methodology. Edited by Hesse-Biber, Gilmartin and Lydenberg.

Oxford: Oxford University Press, 100-137.

Lampert, Jay

1997 "Locke, Fichte and Hegel on the Right to Property." Hegel and the Tradition. Edited by Michael Baur and John Russon. Toronto: University of Toronto Press, 40-73.

Landes, Joan, ed.

1998 Feminism: The Public and the Private. Oxford: Oxford University Press.

Large, Donald W.

1973 "This Land is whose Land?" Wisconsin Law Review: 1039-1083.

Lechte, John

1994 Fifty Key Contemporary Thinkers. New York: Routledge.

Le Doeuff, Michelle 1977 "Women and Philosophy." Radical Philosophy 17, 2-11.

Levey, Ann

2000 "Original Acquisition Arguments and Property." Paper presented at Atlantic Regional Philosophers Association Annual Conference, Halifax, Nova Scotia, Canada. October $14^{\text {th }}$.

Lévinas, Emmanuel

1969 Totality and Infinity: An Essay on Exteriority. Translated by Alphonso Lingis. Pittsburg: Duquesne University Press.

Levi-Strauss, Claude

1963 Structural Anthropology. Translated by Claire Jacobsen. Basic Books.

Locke, John

1960 The Second Treatise of Government. Edited by Peter Laslett. Cambridge: Cambridge University

Press.

Longino, Helen

1990 Science as Social Knowledge. Princeton: Princeton University Press.

Lorenz, Konrad

1966 On Aggression. Translated by Marjorie Kerr Wilson . New York: Harcourt, Brace and World.

Lovins, A. et al 
[984 "Energy and Agriculture." Meeting the Expectations of the Land. Edited by Jackson, Berry and Coleman. Berkeley: North Point Press, 68-86.

Lupton, Deborah

1997 "Foucault and the Medicalisation Critique." Foucault: Health and Medicine. New York: Routledge, 94-I10.

Lutz and Lux, eds.

1970 The Challenge of Humanistic Economics. Menlo Park: Benjamin Cummings.

MacKinnon, Catherine A.

1989 Toward a Feminist Theory of the State. Cambridge, Mass.: Harvard University Press.

Macpherson, C.B.

1962 The Political Theory of Possessive Individualism. London: Oxford University Press.

1978 Propertv: Mainstream and Critical Positions. Toronto: University of Toronto Press.

Makhijani, Arun and Hisham Zerrifi

1996 "The Stewardship Smokescreen." The Bulletin of the Atomic Scientists 52:5, (Sept/Oct), 22.

Mann, Patricia S.

1994 Micropolitics: Agency in a Postfeminist Era. Minneapolis: University of Minnesota Press.

Martin, Emily

1990 "Science and Women's Bodies: Forms of Anthropological Knowledge." Bodv/Politic. Edited by Jacobus, Fox-Keller and Shuttleworth. New York: Routledge, 69-82.

Marsa, Linda

1995 "Whose Ideas are they Anyway? Intellectual Property in the Information Age:" Omni (Winter):37-4l.

Marx, Karl

1977 "Author's Preface to $A$ Contribution to the Critique of Political Economy. " Karl Marx: Selected Writings. Edited by David McLellan. Oxford: Oxford University Press, 388-392.

Massumi, Brian

1993 The Politics of Everyday Fear. Edited by Brian Massumi. Minneapolis: University of Minnesota Press.

1998 "Requiem for Our Prospective Dead: Toward a Participatory Critique of Capitalist Power." Deleuze and Guattari: New Mappings in Politics, Philosophy and Culture. Edited by E. Kaufman and K. J. Heller, Minneapolis: University of Minnesota Press, 40-63.

Mauss, Marcel

1923 "Essai sur le don: forme et raison de l'échange dans les sociétés archaïques." L'Année Sociologique.

1990 The Gift: The Form and Reason for Exchange in Archaic Societies. Translated by W.D. Halls. New York: Norton.

May, Todd

1993 "The System and its Fractures: Gilles Deleuze on Otherness." Journal of the British Society for 
Phenomenology 24:1 (January):3-14.

1993 Between Genealogy and Epistemology: Pyschology. Politics, and Knowledge in the Thought of Michel Foucault. University Park, Penn.: Pennsylvania State University Press

1996 "Gilles Deleuze and the Politics of Time." Man and World 29:3, (July):292-301.

McDonald, Dale

1999 “Who Owns Nature?" Home Farm 32:6, (March):1-4.

McLellan, David

1977 Karl Marx:1818-1883 Selected Writings. Oxford: Oxford University Press.

McMurtry, John

1995 "The Contradictions of Free Market Doctrine: Is there a Solution?" Paper presented to the Westminster Institute Conference, London, Ontario, Canada, (May):20pp.

Mead, Margaret

1937 Cooperation and Competition among Primitive Peoples (1 ${ }^{\text {st }}$ edition). New York: McGraw-Hill.

Meek, R.L.

1976 Social Science and the Ignoble Savage. Cambridge: Cambridge University Press.

Mendelson, E. et al, eds.

1977 The Social Production of Scientific Knowledge. Dordrecht: Reidel.

Merleau-Ponty, $M$.

1962 The Phenomenology of Perception. Translated by Colin Smith. New York: Humanities Press.

Mill, John Stuart

1956 On Liberty. Edited by Currin V. Shields. New York: Liberal Arts Press.

1978 "Principles of Political Economy with Some of Their Applications to Social Philosophy." Property: Mainstream and Critical Positions. Edited by C.B. Macpherson. Toronto: University of Toronto Press.

1998 Utilitarianism, reprinted in Ethics: History, Theory and Contemporary Issues, $2^{\text {nd }}$ edition. Edited by Steven Cahn and Peter Markie. Oxford: Oxford University Press, 343-381.

Millman, Marcia, and Rosabeth Moss Kanter

1987 "Introduction to Another Voice." Feminism and Methodology. Edited by Sandra Harding. Indiana University Press, 1987, 29-36

Milsom, S.F.C.

1969 Historical Foundations of the Common Law. London: Butterworths.

Mullarkey, John

1997 "Deleuze and Materialism: One or Several Matters?" The South Atlantic Quarterly 96:3, 439-463.

Munzer, Stephen R.

1990 A Theory of Property. Cambridge: Cambridge University Press. 
1994 "An Uneasy Case against Property Rights in Body Parts." Social Philosophy and Policy 11:2, 259-286.

Narveson, Jan.

1991 "Resources and Environmental Policy." unpublished paper presented at Ontario Philosophical Society Annual Meeting, Ottawa, Ontario. 10pp.

Narayan, Kirin

1993 "How Native is a 'Native' Anthropologist?" American Anthropoiogist 95:67i-686.

Nicholson. $R$.

1982 “Intellectual Property Rights and Innovation." London: HMSO, (December):14-21.

Nietzsche, Frederich

1964 The Complete Works of Friedrich Nietzsche. Translated by Oscar Levy. New York: Russell and Russell.

1986 Human, All too Human: A Book for Free Spirits. Edited by R. J. Hollingdale. Cambridge: Cambridge University Press.

Nozick, Robert

1974 Anarchy, State, Utopia. New York: Basic Books.

Nullis Clare

2000 “Actress wins Rights to juliaroberts.com."http://www.nandotimes.com. (June 3).

Oelschlaeger, Max.

1991 The Idea of Wilderness. New Haven: Yale University Press.

Okin, Susan Moller

1998 "Gender, the Public, and the Private." Feminism and Politics. Edited by Anne Phillips. Oxford:

Oxford University Press, 116-137.

Overall, Christine

1998 A Feminist I: Reflections from Academia. Peterborough, Ont.: Broadview.

Page, Edgar

1984 "Donation, Surrogacy and Adoption." Journal of Applied Philosophy 1:2, 161-172.

Pateman, Carole

1989 The Disorder of Women. Stanford, Conn.: Stanford University Press.

Patton, Paul

1984 "Conceptual Politics and the War-Machine in Mille Plateaux." SubStance 44/45, 61-80.

Pawson, Eric

1987 "Order and Freedom: A Cultural Geography of New Zealand." Southern Approaches:

Geography in New Zealand. Edited by P.G. Holland and W.B. Johnston. New Zealand Geographical Society Inc. Christchurch, N.Z., 305-328.

1992 "The Land in Cultural Context. Two New Zealands: Maori and European." Inventing Places: Studies 
in Cultural Geography. Edited by Fay Gale and Kay Anderson. Cheshire: Halsted Press, 15-31.

Pedro, A.

1999 "Effects of Obstetrician Characteristics on Cesarean Delivery Rates: A Community Hospital Experience." American Journal of Gynaecologist and Obstetricians 180:1, 1364-1372.

Pera, Pia

1995 Lo's Diary. Farrar, Straus and Giroux.

Piddocke, Stuart

1969 "The Potlatch System of the Southern Kwakiutl: A New Perspective." Environment and Cultural

Behaviour. Edited by Andrew Vayda. Garden City, N.Y.:Natural History Press, 130-153.

Plato

1961 The Collected Dialogues of Plato. Edited by Hamilton and Cairns. Pantheon.

Ploman, E.W. and L. Clark Hamilton

1980 Copyright: Intellectual Property in the Information Age. London: Routledge and Kegan Paul.

Rabinow, Paul

1977 Reflections of Fieldwork in Morocco. Berkeley: University of California Press.

Radin, Margaret J.

1991 "Property and Personhood." Standford Law Review 65:1, (November):955-963.

Rajchman, John

2000 The Deleuze Connections. Cambridge, Mass.: The M.I.T. Press.

Rapp, Rayna

1999 "The Power of "Positive" Diagnosis." Feminist Approaches to Theory and Methodology. Edited by

S. Hesse-Biber, C. Gilmartin and R. Lydenberg, New York: Oxford, 287-300.

Rawls, John

1971 A Theory of Justice. Cambridge: Harvard University Press.

1985 "Justice as Fairness: Political Not Metaphysical." Philosophy and Public Affairs 14, 223-251.

Regan, Tom

1984 Earthbound. New York: Random House.

Reed, Gerard

1986 "A Native American Environmental Ethic: A Homily on Black Elk." Religion and

Environmental Crisis. Edited by Eugene Hargrove. Athens: University of Georgia Press.

Reeve, Andrew, and Jack Lively

1989 Modern Political Theory from Hobbes to Marx: Key Debates. New York: Routledge.

Reeve, Andrew

1986 Property. Atlantic Highlands, N.J.: Humanities Press International.

Rich, Adrienne 
1986 Of Woman Born. New York: W.W. Norton.

Rose, Mark

1993 Authors and Owners: The Invention of Copvright. Cambridge: Harvard University Press.

Rosen, Allen

1992 "Reconsidering the Idea/Expression Dichotomy." U.B.C. Law Review 26, 263-280.

Rosen, Jeffery

1995 "Cheap Speech: Will the Old First Amendment Battles Survive the New Technologies? The New Yorker (August 7):75-80.

Rothman, Barbara Katz

1983 "Midwives in Transition: the Structure of the Clinical Revolution." Social Problems. 30:3, 262-271.

Rousseau, Jean-Jacques

1964 "Discourse on the Origins and the Foundations of Inequality among Men [1755]." The First and Second Discourses. Edited by Roger D. Masters. New York: St. Martin's Press.

1973 The Social Contract and Discourses. Introduction by G.D.H. Cole. London: Fitzhenry \& Whiteside.

Sakala, C.

1993 "Midwifery Care and Out-of-Hospital Birth Settings: How do they Reduce Unnecessary Cesarean Births?" Social Science and Medicine 37:10, 1233-1250.

Sandmark, Peter

1996 "The Impact of New Technologies on Copyright Law." Brief to The Standing Committee on

Canadian Heritage. Independent Film and Video Alliance.

(http://www.culturenet.ca/ifva/pub/copyright.html)

Sargent, C. and N. Stark

1989 "Childbirth Education and Childbirth Models: Parental Perspectives on Control, Anaesthesia, and

Technological Intervention in the Birth Process." Medical Anthropology Quarterly 3:1, 326-347.

Sartre, Jean Paul

1977 "Existentialism is a Humanism." Existentialism and Humanism. Translated by Bernard Frechtman, Haksett Press.

Sawicki, Jana

1991 Disciplining Foucault: Feminism, Power, and the Body. New York: Routledge.

Schaffer, Richard, ed.

1990 "Licensing Transfers of Intellectual Property." Intemational Business Law and its Environment. New York: West Publishing, 389-410.

Schmitt, Carl

1996 The Concept of the Political. Chicago: University of Chicago Press.

Schmidtz, David

1994 "The Institution of Property." Social Philosophy and Policy 11,2:42-62. 
Schrift, Alan, ed.

1997 The Logic of the Gift. New York: Routledge.

Schultz, Vicki.

1992 "Women 'Before' the Law: Judicial Stories about Women, Work, and Sex Segregation on the Job." Feminists Theorize the Political. Edited by Judith Butler and Joan Scott. New York: Routledge, 297-340.

Schwartzenbach, Sibyl

1995 "Rawls and Ownership: The Forgotten Category of Reproductive Labour." Canadian Journal of Philosophy 13:128-145.

Scott, James C

1999 Seeing Like a State. Yale University Press.

Scott, Joan W.

1999 "The Evidence of Experience." Feminist Approaches to Theory and Methodology. Edited by S. Hesse-Biber, C. Gilmartin and R. Lydenberg. New York: Oxford, 79-99.

Sherif, Carolyn Wood

1987 "Bias in Psychology." Feminism and Methodology. Sandra Harding ed. Bloomington: Indiana University Press, 37-56.

Sherover, Charles $\mathbf{M}$. 1995 The Human Experience of Time: The Development of its Philosophic Meaning. New York: New York University Press.

Sherwood, Robert M.

1990 Intellectual Property and Economic Development. Boulder, Co.: Westview Press.

Shiel, James

1968 Greek Thought and the Rise of Christianity. New York: Barnes and Noble.

Shiva, Vandana

1993 Monocultures of the Mind: Perspectives on Biodiversity and Biotechnology. London: Zed Books.

Shuttleworth, Sally

1990 "Female Circulation: Medical Discourse and Popular Advertising in the Mid-Victorian Era."

Body/Politics. Edited by Jacobus, Fox Keller and Shuttleworth. New York: Routledge, 47-68.

Simmons, John A.

1994 "Original-Acquisition Justifications of Private Property." Social Philosophy and Policy 11:2 (Summer):63-84.

Singer, Peter

1977 "Freedoms and Utilities in the Distribution of Health Care." Markets and Morals. Edited by G.A. Dworkin. Washington: Hemisphere.

Smith, Dorothy E.

1987 "Women's Perspective as a Radical Critique of Sociology." In Feminism and Methodology. Edited by Sandra Harding. Bloomington: Indiana University Press, 84-96. 
Spector, Horatio

1991 “Intellectual Property Skepticism." International Journal of Applied Philosophy 6:2, 65-68.

Spock, Benjamin

1945 The Common Sense Book of Baby and Child Care. New York: Simon \& Schuster.

Steidlmeier, Paul

1993 "The Moral Legitimacy of Intellectual Property Claims: American Business and Developing Country Perspectives." Journal of Business Ethics 12:2, I- I4.

Strossen, Nadine

2000 Defending Pornography: Free Speech, Sex, and the Fight for Women's Rights. New York: New York University Press.

Sugden, Robert

1986 The Economics of Rights, Co-operation, and Welfare. Oxford: Blackwell.

Sutherland, John

1995 "The Great Copyright Disaster." London Review of Books (Jan. 12):3-4.

Taussig, Michael

1993 Mimesis and Alterity:A Particular History of the Senses. New York: Routledge.

Taylor, Charies

1986 "Foucault on Freedom and Truth." Foucault: A Critical Reader. Edited by David Couzens Hoy.

Oxford, U.K.: Basil Blackwell: 69-102.

Treichler, Paula

1990 "Feminism, Medicine and the Meaning of Childbirth." Body/Politics. Edited by Jacobus, Fox-Keller and Shuttleworth. New York: Routledge, 113-138.

Trevor, Margaret C.

1999 "Political Socialization, Party Identification, and the Gender Gap." Public Opinion Quarterly 62-89.

Tully, James

1994 "Aboriginal Property and Western Theory: Recovering a Middle Ground." Social Philosophy and Policy 11,2:153-180.

Ussher, $\mathrm{J}$.

1991 Women's Madness: Misogyny or Mental Illness. New York: Harvester Wheatsheaf.

Veblen, Thorstein

1978 "The Natural Right of Investment." Property: Mainstream and Critical Positions. Edited by

C.B.Macpherson. Toronto: University of Toronto Press.

Vega, Gustavo

1990 "Mexico, The U.S. and Canada: Issues and Prospects for Freer Trade." Center for Trade Policy and Law 16, 30pp.

Virillio, Paul

1986 Pure War. New York: Semiotext(e). 
1986 Speed and Politics. New York: Semiotext(e).

Walens, Stanley

1981 Feasting with Cannibals: An Essay on Kwakiult Cosmology. Princeton, N.J.: Princeton University Press.

Waldron, Jeremy

1994 "The Humean Theory of Property." Social Philosphy and Policy, 11:2, (Summer):85-123.

Webster's Third New International Dictionary.

1976 Springfield, Mass.: Merriam.

Weir, Alison

1996 Sacrificial Logics : Feminist Theory and the Critique of Identity. New York: Routledge.

2000 "From the Subversion of Identity to the Subversion of Solidarity? Judith Butler and the Critique of Women's Identity." Open Boundaries. Edited by Barbara A. Crow and Lise Gotell. Toronto: Prentice Hall Allyn and Bacon Canada, 43-50.

White Jr., Lynn

1967 "The Historical Roots of Our Ecologic Crisis." Science March 10:1203-7.

Wolf, Eric

1999 "The Kwakiutl." Envisioning Power: Ideologies of Dominance and Crisis. Berkeley: University of California Press, 69-131.

Wolf, Naomi

2000 "A Call for Truth." Contemporary Moral Issues, $2^{\text {nd }}$. Edited by Lawrence Hinman. New Jersey: Prentice-Hall, 31.

Wong, Jan

1992 "China: Inside the Closet. Gays Find a Space Between Ignorance and Intolerance", The Globe and Mail Toronto, ( November 14th):Al;Al4.

Worster, Donald

1984 "Good Farming and the Public Good." Meeting the Expectations of the Land. Edited by Wes

Jackson, Wendell Berry and Bruce Coleman. San Francisco: North Point Press,3 I-4 I.

Wylie, A. et al, eds.

1990 "Feminist Critiques of Science: A Comprehensive Guide to the Literature." Resources for Feminist Research 90:2.

Young, Elspeth,

1992 "Hunter-Gatherer Concepts of Land and its Ownership in remote Australia and North America." Inventing Places: Studies in Cultural Geography. Edited by Fay Gale and Kay Anderson. Cheshire: Halstead Press, 256-272.

Young, Iris Marion

1984 "Pregnant Embodiment: Subjectivity and Alienation." The Journal of Medicine and Philosophy 9: 45-62. 
1989 "Throwing like a Girl: A Phenomenology of Feminine Body Comportment, Motility, and Spatiality." The Thinking Muse: Feminism and Modern French Philosophy. Edited by Jeffner Allen and Iris Marion Young. Indiana University Press, 5 1-70.

1998 "Impartiality and the Civic Public: Some Implications of Feminist Critiques of Moral and Political Theory." Feminism: The Public and the Private. Edited by Joan Landes. Oxford: Oxford University Press, 421-447. 